
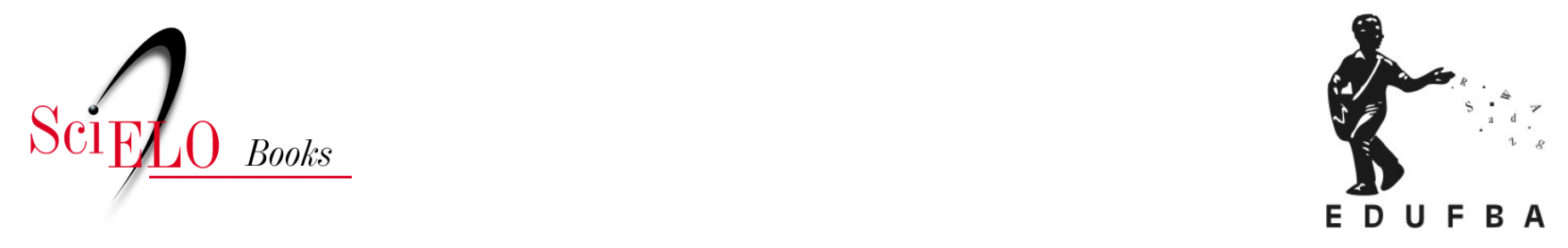

\title{
A cena musical da Black Rio estilos e mediações nos bailes soul dos anos 1970
}

\author{
Luciana Xavier de Oliveira
}

OLIVEIRA, L. X. A cena musical da Black Rio: estilos e mediações nos bailes soul dos anos 1970 [online]. Salvador: EDUFBA, 2018, 302 p. ISBN: 978-85-232-1872-0.

https://doi.org/10.7476/9788523218720.

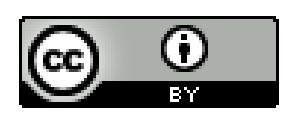

All the contents of this work, except where otherwise noted, is licensed under a Creative Commons Attribution $\underline{4.0 \text { International license. }}$

Todo o conteúdo deste trabalho, exceto quando houver ressalva, é publicado sob a licença $\underline{\text { Creative Commons }}$ Atribição 4.0.

Todo el contenido de esta obra, excepto donde se indique lo contrario, está bajo licencia de la licencia Creative Commons Reconocimento 4.0. 
A cena musical da
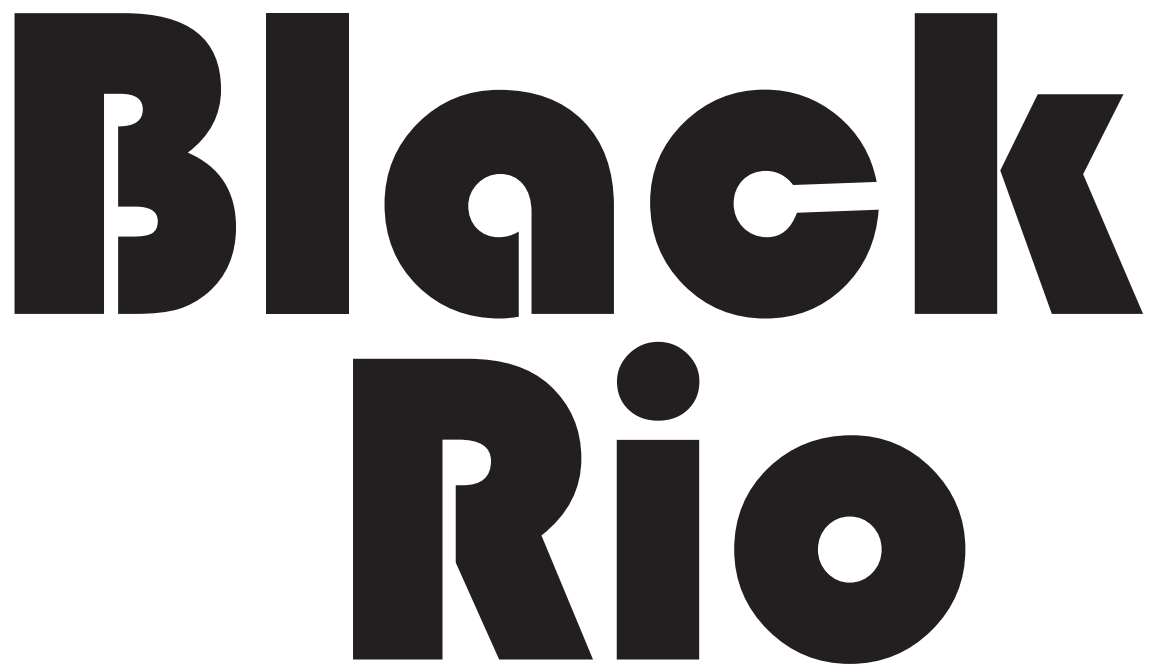


\section{UNIVERSIDADE FEDERAL DA BAHIA}

\section{REITOR}

João Carlos Salles Pires da Silva

VICE-REITOR

Paulo Cesar Miguez de Oliveira

ASSESSOR DO REITOR

Paulo Costa Lima

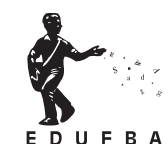

\section{compós}

\section{EDITORA DA UNIVERSIDADE FEDERAL DA BAHIA}

DIRETORA

Flávia Goulart Mota Garcia Rosa

CONSELHO EDITORIAL

Alberto Brum Novaes

Angelo Szaniecki Perret Serpa

Caiuby Alves da Costa

Charbel Niño El Hani

Cleise Furtado Mendes

Evelina de Carvalho Sá Hoisel

José Teixeira Cavalcante Filho

Maria do Carmo Soares de Freitas

Maria Vidal de Negreiros Camargo

\author{
ASSOCIAÇÃO NACIONAL DOS \\ PROGRAMAS DE PÓS-GRADUAÇÃO \\ EM COMUNICAÇÃO (COMPÓS) \\ PRESIDENTE \\ Marco Roxo \\ VICE-PRESIDENTE \\ Isaltina Gomes \\ SECRETÁRIA-GERAL \\ Gisela Castro \\ PROGRAMA DE PÓS-GRADUAÇÃO EM \\ COMUNICAÇÃO DA UNIVERSIDADE DE \\ BRASÍLIA (UNB), CAMPUS DARCY RIBEIRO, \\ ICC NORTE - SUBSOLO, SALA ASS 633. ASA \\ NORTE, BRASÍLIA - DF. CEP: 70910-900
}




\section{Luciana Xavier de Oliveira}

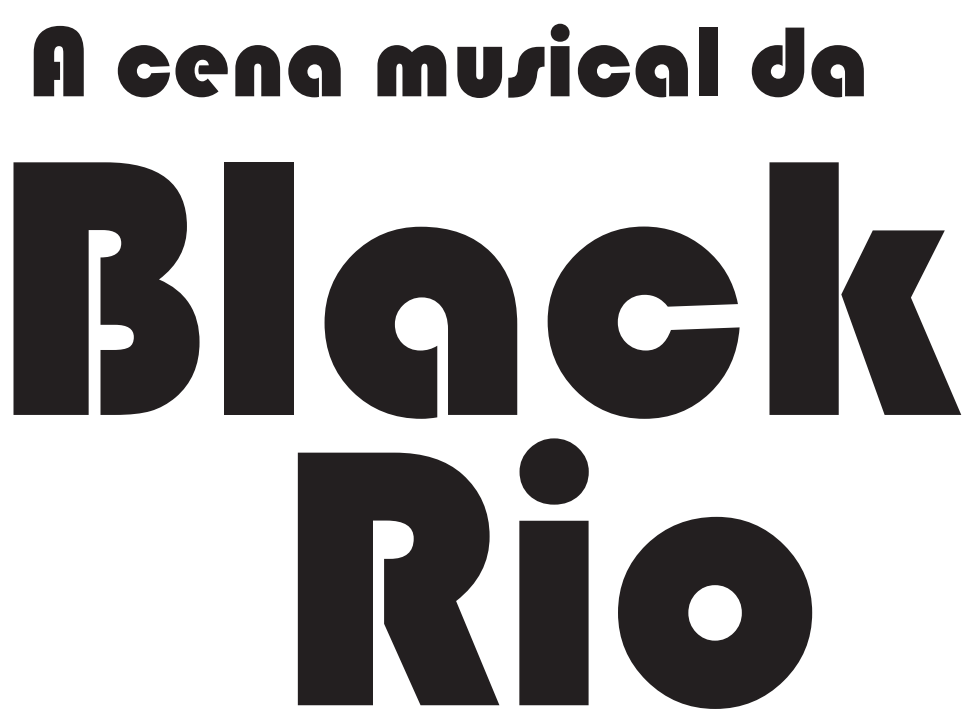

Estilo e mediações nos

bailes soul dos anos 1970 
2018, Luciana Xavier de Oliveira.

Direitos dessa edição cedidos à Edufba.

Feito o Depósito Legal

Grafia atualizada conforme o Acordo Ortográfico da

Língua Portuguesa de 1990, em vigor no Brasil desde 2009.

\author{
Capa, Projeto Gráfico e Diagramação \\ Rodrigo Oyarzábal Schlabitz \\ Revisão \\ Mariana Rios Amaral de Oliveira
}

\author{
Normalização \\ Sandra Batista \\ Imagem da Capa \\ @freevector
}

Sistema de Bibliotecas - SIBI/UFBA

O48 Oliveira, Luciana Xavier de.

A cena musical da Black Rio: estilos e mediações nos bailes soul dos anos 1970 / Luciana Xavier de Oliveira. - Salvador: EDUFBA, 2018.

$302 \mathrm{p}$.

ISBN 978-85-232-1720-4

1. Dança. 2. Dança - estilos. 3. Bailes. 4.Música. I. Luciana Xavier de Oliveira.

CDU 793.3

Editora afiliada à
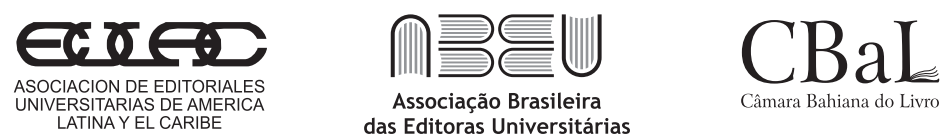

Editora da UFBA

Rua Barão de Jeremoabo, s/n - Campus de Ondina 40170-115 - Salvador - Bahia Tel.: +55 71 3283-6164

www.edufba.ufba.br / edufba@ufba.br 


\section{Agradecimentos}

Primeiramente, é preciso fazer um agradecimento especial ao Programa de Pós-Graduação em Comunicação (PPGCOM) e à Universidade Federal Fluminense (UFF), que me receberam, acreditaram no meu projeto e me deram a oportunidade de poder aprender e me aprofundar na vida acadêmica. Agradeço à Coordenação de Aperfeiçoamento de Pessoal de Nível Superior (Capes) pelo financiamento desta pesquisa e pelo apoio à realização do estágio de doutorado sanduíche, que contribuiu muito para meu enriquecimento acadêmico, profissional e intelectual.

Obrigada à Associação Nacional dos Programas de Pós-Graduação em Comunicação (COMPÓS) por proporcionar a edição desse trabalho. E agradeço muito à EDUFBA, especialmente à Flávia Goulart e a equipe editorial pela paciência, compreensão e sensibilidade no conturbado processo de produção desse livro.

Agradeço muito a meu orientador, Felipe Trotta, pelas ideias, disponibilidade, compreensão e paciência, me ensinando muito sobre a "arte da dúvida".

Quero agradecer aos queridos professores que aceitaram participar da avaliação deste trabalho e que colaboraram muito para o desenvolvimento da pesquisa. Obrigada a Marco Roxo, pelos importantes insights e por ter acreditado desde o começo neste projeto. Obrigada a Jorge Cardoso, amigo e 
inspiração para toda a vida, um modelo a ser seguido. Obrigada a dois grandes mentores intelectuais e espirituais, Micael Herschmann e Liv Sovik, heranças queridas da Escola de Comunicação (ECO) da Universidade Federal do Rio de Janeiro (UFRJ), pelo incentivo, atenção, carinho e disponibilidade sempre, pelas sugestões e por tornarem o mundo da pesquisa um universo instigante e prazeroso para mim.

Obrigada também a todos os professores do PPGCOM, em especial Fernando Resende, que me abriu uma porta magnífica que me deu a oportunidade de poder entrar em contato com a Universidade de Tubingen, na Alemanha.

Aos amigos, tantos e maravilhosos, de muitos lugares, o desejo era agradecer um por um, mas a tarefa é impossível. Mas agradeço, especialmente, a Simone Evangelista, Juliana Gagliardi, Thiago Soares, Renata Cardoso e Fernanda Carrera, que entrou comigo nesta jornada. Agradeço também ao professor George Yúdice, pela preciosa contribuição e diálogo.

Quero agradecer ainda à Universidade de Tubingen e ao Serviço Alemão de Intercâmbio Acadêmico (Daad) pela bolsa oferecida para o intercâmbio acadêmico na referida universidade, por ocasião do projeto Literary Cultures of the Global South, representado pelo professor Russell West-Pavlov e pelo amigo querido Andree Gerland.

Obrigada, por fim, a meus familiares, sempre ao meu lado em momentos bastante difíceis. E, por fim, agradeço aos meus dois maiores amores e exemplos, minha mãe Dalva e minha avó Leda. Sem elas, nada disso seria possível. 
Para minha mãe Dalva

Minha avó Leda (em memória)

Meu grande amigo Pedro Sangirardi (em memória) 
É preciso a imagem para se recuperar a identidade. Tem-se que se tornar visivel. Porque o rosto de um éo reflexo do outro. O corpo de um é o reflexo do outro. E cada um o reflexo de todos os corpos.

Beatriz Nascimento (Orí, 1989) 


\section{Sumário}

\section{Introdução}

29 Cenas musicais e estilos

33 Cenas, identidades e consumo cultural

40 Percursos metodológicos

47 Os estilos em cena

55 Bailes e clubes de subúrbio

57 desenfreado das danças: bailes negros populares no século $\mathrm{XX}$

60 Uma nova cidade: desenvolvimento suburbano

64 Clubes e bailes de salão

73 O movimento

97 Hello, crazy people!

102 Bailes $\mathbf{1 0 0 \%}$ soul

107 As Noites do Shaft e o Clube Renascença

118 O soul em alta velocidade

120 Os DJs e as equipes de som

138 A indústria fonográfica no Brasil dos anos 1970

141 O segmento do soul

150 A Banda Black Rio

153 MPB+soul

155 Brazilian disco music 


\title{
159 Blacks sob vigilância
}

160 A esquerda nacionalista e a alienação do soul

172 Direita, ditadura e repressão

181 O fim dos bailes?

189 O estilo da Black Rio

192 Classe média negra

201 Novos estilos, novas negritudes

208 Black movies

212 Moda e consciência

227 Cabelos politizados

\author{
237 A música dos bailes \\ 238 Um álbum de equipe \\ 242 A emergência do soul \\ 248 Uma black em uma moto \\ 251 O LP faixa a faixa \\ 256 Música altamente dançável
}

265 Conclusões

281 Referências 


\section{Introdução}

Black Rio, Black Soul, Black Power ou apenas Soul. Foram diversos os nomes usados ao longo do tempo para identificar essa cena musical desenvolvida em meados da década de 1970 na cidade do Rio de Janeiro. Sob o lema emblemático do Black is beautiful, eventualmente traduzido para o português, negros se descobriram lindos dançando ao som da soul music em grandes bailes sediados, em princípio, nos subúrbios cariocas. Da cena que se configurou em torno da atuação das centenas de equipes de som responsáveis por estruturar um grande conjunto das festas que reuniam milhares de jovens nos finais de semana, emergiu uma estética particular que conectava a juventude negra periférica brasileira às produções negras internacionais, notadamente norte-americanas. Esse contexto gerou um conjunto heterogêneo de políticas de estilo que apresentavam uma alternativa de ação político-cultural, afirmação identitária e acesso à cidadania em um momento de intensas polarizações políticas e de grande repressão em meio à ditadura militar. Nesta pesquisa, proponho-me a compreender como os participantes da cena musical da Black Rio apresentavam diferentes exercícios subjetivos e diferentes formas de sociabilidades na configuração de políticas culturais ao apresentar novas maneiras de se posicionar na arena pública e de se expressar subjetivamente, buscando uma via entre a esquerda militante tradicional e a direita 
apoiadora do regime, entre as tradições culturais afro-brasileiras e as influências da globalização, em constante diálogo com o mercado. Como, por meio de um estilo particular, esses jovens deixaram uma marca no espaço urbano e inseriram também uma rasura nos discursos defensores da democracia racial brasileira e de valorização da mestiçagem? E ainda, como os participantes dessa cena musical apresentaram novas possibilidades e visões para os movimentos negros brasileiros?

A popularização da música soul no Brasil criou um segmento lucrativo no interior da indústria fonográfica local, o que provocou um aumento da difusão da música norte-americana no país, mas também abriu espaço para o lançamento de artistas locais praticantes do gênero. Essas novas produções musicais e o repertório de imagens e mensagens englobadas por elas passaram a influenciar decisivamente comportamentos e estéticas e foram utilizadas como recursos simbólicos na construção e difusão de um estilo e de uma ideologia política altamente influenciada pela cultura afro-americana de massa e pelos diversos movimentos negros internacionais. $\mathrm{O}$ aumento do consumo dos discos de soul e de outros gêneros norte-americanos gerou o desenvolvimento de novos segmentos de mercado, formados em meio a uma crescente oferta de empregos - especialmente nas indústrias e no setor de serviços -, motivada pelo "milagre econômico" promovido pelo governo militar. A política econômica da ditadura nos anos 1970 também abriu o país para o capital internacional, o que gerou o barateamento de bens de consumo, como roupas, discos, televisores e equipamentos de som, acompanhando o desenvolvimento dos veículos de comunicação de massa. A expansão da comunicação de massa, processo já iniciado com a administração de Juscelino Kubitschek (1956-1961), foi particularmente incentivada durante o governo militar, o que contribuiu para a consolidação da indústria cultural no país e possibilitou a configuração de uma produção cultural internacional-popular, potencializando o sistema de trocas simbólicas. (DIAS, 2000, p. 51) O "milagre", em curto prazo, aumentou a circulação de capital e possibilitou um maior poder de compra para a população - apesar de, dez anos depois, ter colaborado para o aumento da dívida externa e para a hiperinflação. Além de mais informação disponível, havia um maior acesso da população à educação formal, o que gerava a criação de novas aspirações culturais e desejos de consumo que 
estimulavam impulsos de distinção, motivados por um contato maior com uma cultura globalizada. Esse contexto atingiu os subúrbios e regiões periféricas do Rio de Janeiro, foco desta pesquisa, majoritariamente compostos por populações afrodescendentes menos favorecidas, mas também por uma pequena classe média negra em ascensão.

Essa população frequentadora dos bailes de soul ajudou a consolidar um estilo de moda e de comportamento que mesclava as várias informações visuais que recebiam através de revistas, filmes, programas de TV e capas de discos, o que favoreceu o desenvolvimento de diferentes estratégias de contestação da estrutura social e racial vigente a partir de rituais simbólicos e práticas de consumo alternativas. Esse impulso por uma diferenciação a partir da escolha de determinados itens do vestuário e a utilização do cabelo natural, inspirado no visual dos integrantes do movimento Black Power norte-americano, demarcava uma tentativa de incorporação de uma estética internacional articulada a um conjunto de símbolos marcadamente diaspóricos, que estabeleciam táticas de diferenciação e dissenso em relação ao ambíguo mito da democracia racial, refletindo um sentimento de esgotamento e de fracasso de uma perspectiva integracionista do negro brasileiro (GIACOMINI, 2006, p. 212), que, direta ou indiretamente, ainda contribuía para a manutenção da precária situação dessas populações na sociedade.

Catalisando uma política pautada pela identidade (HANCHARD, 2001) e pelo estilo, a cena dos bailes black cariocas também representava um contexto, em um primeiro momento, marginal e alternativo, mas que logo passou a se articular a uma cultura mainstream, integrando-se à paisagem cultural da cidade ao proporcionar novas formas de entretenimento, produção, circulação e escuta musical. E também ao apresentar novos segmentos de mercado e diferentes estratégias interpretativas e de consumo cultural, entrelaçando estética, performance, linguagem, sonoridades e discursos. Em sua proposição de outros exercícios identitários, a cena Black Rio concretizava novas formas de negociação de posições, acionando diversas representações por meio de estratégias significativas que possibilitavam uma cidadania cultural transversal e uma ação política alternativa, guiada por um viés estético, na tentativa de transgredir fronteiras sociais e raciais. Um estilo que se tornava indício de disputas em torno de novos significados e de novos exercícios 
identitários, simbolizando, ao mesmo tempo, uma recusa a estereótipos e a visões homogeneizantes e também um desafio oblíquo a expressões tradicionais mais estabelecidas.

[...] moças e rapazes de roupas extravagantes e coloridas, calças berrantes, sapatões de sola dupla (pisões), vestidos longos, blusas afro, colares de marfim e cabelos eriçados. Gente alta, elástica, de olhar firme e seguro, que, inspirada em modas nova-iorquinas, preferiu escolher para si uma nova aparência, capaz de negar simultaneamente o surrado traje do malandro carioca e o uniforme colonial das escolas de samba. (BLACK RIO, 1976, p. 154)

O estilo proposto pelos blacks nunca compôs um conjunto estável de marcas e gestos, pois era recortado por diferenças étnicas que não coincidiam integralmente nem formavam uma totalidade homogênea. Mas, ao apresentar novas dramatizações de linguagens e identidades, essas performances estrategicamente e convenientemente propunham imagens e discursos positivos em torno de uma conscientização racial, tomando por base uma valorização estética e uma celebração festiva da diferença, no lugar de atuações político-pedagógicas mais convencionais. Uma diferença baseada no significado, que é crucial à cultura, aberto a dinâmicas e reapropriações dialógicas. (HALL, 2003, p. 33)

Era nas pistas de dança dos bailes onde se performatizava um ideal de negritude (ou uma negritude ideal) que dizia respeito a estilos, afetos e sentimentos, também estrategicamente compartilhados com outros grupos, atravessando fronteiras de cor e classe, a partir da valorização de uma estética que reivindicava, no terreno da ação política, uma maneira de ultrapassar barreiras impostas pelo racismo e pela desigualdade. Essa estratégia, que era política, se manifestava no campo da cultura popular e se referia ainda a formas de lutas pela hegemonia cultural por meio da proposição de novas políticas de representação, desencadeadas diante dos deslocamentos de poder ocasionados pelas transformações mundiais.

Os bailes soul deixavam implícitas duas dimensões: o fascínio e o diálogo. O fascínio que exercia sobre grupos de jovens, em um apelo voltado não apenas para negros e pobres, a partir da oferta de diferentes formas de sociabilidade, expressão e estética; e o diálogo com formas culturais modernas, 
cosmopolitas, que proporcionavam novas referências de consumo, comportamento e comunicação, ainda que ancoradas em discursos baseados em tradições e sentimentos comunitários e de solidariedade. Os sentidos que emergiram dessa cena musical e os vestígios de suas memórias coletivas se colocaram como uma possibilidade para a compreensão de sua configuração no tempo passado, a partir da interpretação dos seus efeitos remanescentes na linguagem e no estilo desenvolvido, ajudando a "desembaraçar" uma complexa teia de representações culturais. Representações que não são menos reais que as relações sociais e servem como ponto de partida para essa análise sociológica e comunicacional.

Para a pesquisa dos sentidos da cena da Black Rio, utilizo como referencial teórico as reflexões desenvolvidas no âmbito dos estudos culturais a respeito de compreensão das políticas culturais configuradas a partir da negociação das diferenças e dos seus significados. Para Hall (1997), a cultura exerce uma ação constitutiva da vida social, pois faz parte da estrutura real empírica da sociedade, organizando várias atividades institucionais e atuando como força de mudança histórica ao influenciar identidades individuais e sociais. Dessa forma, é possível compreender a música popular enquanto integrante da produção cultural de uma sociedade e como mediadora de experiências sociais, de acordo com Trotta (2005), que articula também noções de gênero, raça e classe. Também incorporo ao posicionamento teórico desta pesquisa as proposições de Jesús Martín-Barbero (2008) a respeito das mediações socioculturais, especialmente as "mediações comunicativas da cultura”, desenvolvidas a partir dos produtos culturais e compostas por etapas como tecnicidade, institucionalidade, ritualidade e socialidade. Na aproximação das ideias de mediação e dos estudos de comunicação, a cultura assume uma natureza comunicativa a partir do momento em que produz significações, e não apenas serve como espaço de circulação de informações, convertendo o receptor em um produtor de sentidos, para além de um simples decodificador das mensagens transmitidas pelo emissor. Na apropriação dessa visão, penso que as cenas musicais, como espaços de mediação comunicativa em torno da música massiva, implicam ritualidades estabelecidas pelo consumo musical, que dialogam com novas tecnologias de comunicação e com diferentes instituições sociais na construção de novas sociabilidades. Nesses 
processos de mediação é que se estabelecem estilos variados e performances ancoradas em discursos identitários e construções subjetivas.

Se as cenas mediam as relações entre a música massiva e determinados grupos sociais, elas também se inscrevem em processos ligados à economia da música, cujos aspectos também estão previstos no mapa das mediações de Martín-Barbero (2008), o que torna imprescindível nos estudos sobre cenas musicais a abordagem de aspectos da indústria fonográfica e do mercado, visto que economia e cultura estão interconectadas na vida contemporânea. Nesse sentido, a Black Rio também é vista em sua perspectiva econômica, e tentarei discutir aspectos ligados às tensões geradas sobre discussões a respeito do lugar da música na sociedade contemporânea, que levam a embates pela legitimidade da cena, estabelecendo diferentes juízos de valor sobre a música popular massiva como vetor de expressão cultural popular. Assim, na compreensão da cena black carioca, objetivo analisar processos de produção, circulação e consumo de artefatos da chamada indústria cultural sob uma perspectiva comunicacional, para a compreensão dos modos de produção de sentido que levaram à configuração de políticas de estilo, considerando o entorno midiático, o contexto histórico, os aspectos econômicos, estratégias de difusão e recepção, os rituais e atos de consumo que compõem as etapas das mediações atualizadas nessa cena musical.

Para dar conta desses aspectos, pareceu-me insuficiente aplicar recursos metodológicos baseados em entrevistas pessoais em profundidade. Pois estratégias metodológicas ligadas à história oral poderiam centrar em demasia o interesse e a reflexão da pesquisa sobre trajetórias individuais, memórias subjetivas e aspectos pessoais e poderiam não contemplar um horizonte subjetivo mais amplo que pretendo abordar. Mas recorri a entrevistas abertas tanto com participantes anônimos quanto com personalidades reconhecidas da cena, a fim de completar lacunas da pesquisa e também como forma de captar sensações e expectativas que dessem conta da compreensão das estruturas de sentimento configuradas a partir da cena musical, uma maneira de ilustrar discursos e formações culturais emergentes "em que se formula o que se sente, mas que ainda não foi formulado”. (SOVIK, 2009, p. 159)

Junto a esse recurso, empreendi uma pesquisa em fontes bibliográficas e hemerográficas, especificamente em publicações que circularam durante o 
desenrolar da Black Rio, como forma de aprofundamento na atmosfera daquele momento. Na complementação da pesquisa, também utilizei material mais atual que pudesse completar dados, bem como produções audiovisuais disponíveis, documentários e reportagens que tivessem alguma relação com o fenômeno estudado e que auxiliaram a conhecer melhor o clima da época, compondo o mosaico de referências a partir do qual a Black Rio foi gestada e desenvolvida. Na reconstituição da cena musical, também foi importante coletar dados de artefatos que circulavam nesse contexto, como volantes, faixas, cartazes, fotos, imagens de filmes, capas de Long Playing (LPs), a fim de descobrir novos detalhes e acessar uma iconografia que inspirava e compunha o estilo dos participantes dos bailes soul.

Como forma de compreender a estruturação das gramáticas do gênero do soul e suas dinâmicas de produção de sentido na cena da Black Rio, também analisei um dos discos mais relevantes lançados no período, que alcançou elevados números de vendas, materializando e colocando em circulação um conjunto de canções representativas que configuraram performances de gosto e interpretações corporais a partir da dança, traços que também compunham o estilo black. A análise desse produto vai possibilitar a compreensão de aspectos plásticos e elementos materiais, como formatos fonográficos e modelos de circulação que estabeleceram modos de mediação entre as condições de produção e de reconhecimento, além de estratégias de leitura e endereçamento, tendo em vista também condições contextuais de sua criação.

Chamou a atenção ainda, durante a pesquisa, a existência de uma série de documentos ligados à polícia secreta do regime militar que registraram investigações em relação aos bailes, organizadores e participantes. Esses relatórios oferecem ricos detalhes sobre as movimentações em torno dos bailes. E, ao lado das publicações de jornais do período, disponibilizam o acesso ao olhar de alguns setores da sociedade em relação aos bailes e em relação às ações de mobilização racial em geral, o que auxilia na compreensão de juízos de valor e críticas correspondentes a disputas em torno dos significados da "cultura negra" brasileira.

Esse estudo de caso pretende preencher uma lacuna, visto que, dentre as pesquisas na área de comunicação social, a cena musical da Black Rio ainda não foi alvo de trabalhos acadêmicos. Com efeito, causa espécie constatar 
que esse tema já tenha sido alvo de estudos em áreas como antropologia e sociologia, música, geografia, história e até em letras, mas nada ainda produzido em comunicação. Apesar de serem muitos os trabalhos que abordam os diversos aspectos comunicativos e sociais relativos ao funk carioca, o movimento Black Rio é apenas tangenciado em sua história, como um momento embrionário do funk, mas sem ter sua especificidade dimensionada - da mesma forma, a própria questão racial não é um tema muito privilegiado nos programas de pós-graduação em comunicação no Brasil. É meu interesse, ainda, com esta pesquisa, contribuir para a expansão e o desenvolvimento de reflexões em torno da noção de cena musical, ampliando seu escopo para abordar questões ligadas à etnicidade e à racialidade e propondo novas visões para a compreensão das manifestações musicais nas práticas sociais urbanas, articulando conceitualmente cena musical e estilo.

Antes de mais nada, é importante delimitar alguns conceitos e termos utilizados ao longo do trabalho e que precisam ser lidos dentro do contexto em que foram empregados. É importante enfatizar que termos como "raça" e "negro" são empregados enquanto significantes contextuais que devem ser relativizados a fim de não se incorrer em essencialismos, mesmo que, por vezes, ao longo do texto, essas expressões sejam utilizadas enquanto categorias nativas. Mas, do nosso ponto de vista, se o conceito de raça é uma construção social com pouca ou nenhuma referência biológica, ele ainda importa nas discussões sobre o racismo e as hierarquias de cor no Brasil, práticas que se concretizam na vida diária. A ideia de raça, nesse aspecto, fortalece distinções sociais também atravessadas por classe e outras categorias, enfatizando distinções sociais, estereótipos e determinando interações sociológicas e históricas que precisam ser discutidas.

Dessa maneira, é possível considerar cor e raça não como categorias biológicas, mas “categorias cognitivas” (MUNANGA, 2004) que estão relacionadas à história da colonização, do sistema escravocrata e do racismo. Igualmente, a identidade negra não é um fator ou uma estrutura essencial, mas se refere a um lugar de fala e de produção de subjetividade a partir de processos relacionais e dialógicos, vivências e experiências, que variam no tempo e no espaço. Como sinaliza Sovik (2004, p. 365), “[...] a cor é uma variável dependente, pois a autoidentificação se faz comparativamente e o contexto 
familiar, de classe, regional (que pode mudar através da história) define o leque de respostas possíveis”. Assim, ideias como raça, cor e identidade negra, enquanto categorias nativas, designam aspectos da vida social dos sujeitos e se estruturam como conceitos fortemente ideológicos e ainda como categorias sociopolíticas, cujas muitas conotações passam pela expressão cultural popular, mas também abarcam desigualdades sociais. Da mesma forma, é importante mencionar que o termo "branco", enquanto categoria social e racial, também é relativo e se refere a uma prática e exercício social que tem conexão com a aparência, mas, mais ainda, se estabelece como um lugar de poder e de estatuto social, manifesto nas relações cotidianas.

Se, ao longo deste trabalho, os termos "identidade negra" e "negritude" (no inglês, blackness) são utilizados como categorias nativas sinônimas, a sua origem e positividade se referem ao movimento da négritude, em sua grafia original, de caráter cultural, ideológico e literário, criado na década de 1930, que propunha uma revisão da dicotomia Ocidente/Oriente a partir da perspectiva dos valores africanos, como nos ensina Munanga em seu livro Negritude: usos e sentidos (1988). A negritude foi difundida por intelectuais da África e do Caribe espalhados pelo mundo, em que o reconhecimento da filosofia, da arte e da estética negras seria um instrumento de afirmação do negro e uma reflexão das relações de dominação colonial. Essa valorização que passava pela cultura reivindicava uma atitude política e um reconhecimento, pregando a união em torno de uma origem africana com o propósito de combater o racismo. Assim, tradicionalmente, uma das formas de exercício da identidade negra passaria por essa herança cultural africana e por uma mobilização mediante uma autodefinição positiva baseada em uma consciência étnica e política. O passado africano (e mítico), pois, seria o vetor da mobilização, da mesma forma que a partilha de vivências relativas à experiência da escravidão e do racismo.

Ao considerar a variação do emprego das terminologias de acordo com distintas situações, Sansone (2004) observa uma mudança nos termos utilizados diante das diversas situações ligadas à autoidentidade, que podem ser geridas por gostos e preferências, valores, aspirações e formas de ocupar espaços sociais. Se a identidade negra é uma construção social que se relaciona ao lugar ocupado na sociedade pelo indivíduo, ela também se refere à forma 
como as pessoas se percebem e como criam suas próprias narrativas, de formas inconstantes e, eventualmente, contraditórias, refletindo visões de mundo, experiências particulares e constrições do grupo no qual estão inseridas. Isso comprova o caráter relacional e variável da identidade negra de acordo com situações e ambientes e pode ser utilizada como recurso estratégico para enfatizar posições e diferenças. É daí que podemos compreender por que os participantes da cena do soul preferiam se identificar como blacks, especialmente no que se refere ao território dos bailes, se referindo a uma identidade mais potente e positiva, jovem e cosmopolita, do que como negros, pretos ou ainda como afro-brasileiros. Os bailes, aqui, são compreendidos como territórios, espaços significativos que abarcavam em si a manifestação das identidades, que demarcavam um lugar a partir da diferença. E, tal qual as identidades, o território da cena black apresentava um caráter móvel, fluido e nômade, ligado a um conjunto estético relacionado a uma cultura negra midiatizada, que já não necessariamente passaria por uma africanidade, mas cujas vivências globalizadas demarcavam um novo processo de recriação cultural coletiva, que possibilitaria novos posicionamentos na sociedade e políticas culturais alternativas. E, portanto, novas negritudes.

Outra expressão utilizada ao longo do trabalho foi o termo "movimento", um rótulo criado pela imprensa em relação à Black Rio, logo apropriado pelos seus participantes na linguagem corrente, transformado em categoria nativa. É assim que a expressão aparece neste livro. Decerto, a Black Rio nunca se configurou efetivamente como um movimento social que, como postula Scherer-Warren (1987, p. 13), se define por um

[...] grupo mais ou menos organizado, sob uma liderança determinada ou não; possuindo programa, objetivos ou plano comum; baseando-se numa mesma doutrina, princípios valorativos ou ideologia; visando um fim específico ou uma mudança social.

Como observei ao longo da pesquisa, tanto as equipes quanto DJs quanto produtores não possuíam uma bandeira única, e muitos tentavam dissipar suspeitas advindas dos militares de que os bailes pudessem ter qualquer conotação política ou de mobilização racial, como fizeram questão de frisar, 
respectivamente, Nirto, um dos donos da equipe Soul Grand Prix (SGP), e Mr. Funky Santos, pioneiro dos bailes soul:

Esse negócio é muito melindroso, sabe? Poxa, não existe nada de político na transação. É o pessoal que não vive dentro do soul e por acaso passou e viu, vamos dizer assim, muitas pessoas negras juntas, então se assusta. Se assustam e ficam sem entender o porquê. Então entram numa de movimento político. Mas não é nada disso [...]. É curtição, gente querendo se divertir. (FRIAS, 1976, p. 6)

Então, se a gente for implantar um movimento desses, a gente está arriscando a se quebrar. Não é uma boa, eu não aconselho ninguém a fazer. Porque o soul é o caminho da comunicação entre os negros. Não é um movimento negro. É um movimento de negros. (FRIAS, 1976, p. 5)

$\mathrm{Na}$ fala dos dois produtores, há duas pistas que podem levar à compreensão dos sentidos da Black Rio: o seu caráter aglutinador em torno do lazer, que assumia status político, mas não no sentido convencional; e a sua face comunicativa, que fez da cena um espaço de materialização dos processos de mediação e globalização cultural. São essas manifestações que pretendo analisar nesta pesquisa, tomando o cuidado de não apontar a Black Rio como um braço, uma etapa ou um processo integrante da constituição do movimento negro brasileiro. Obviamente, a ligação de participantes com os bailes e as organizações negras é apresentada e discutida, mas não foi meu intuito me deter sobre a trajetória particular de organizações e militantes que se relacionavam ao contexto do soul.

Desse ponto de vista, a vitalidade e a potência política da cena black se remetiam mais à constituição de um horizonte geral de expectativas geradas nos processos de mediação que tornaram os bailes espaços de partilha de experiência e reconfigurações identitárias por meio do estilo e novas estratégias culturais. Havia trocas, convergências, diálogos com diversas instâncias de movimentos negros (brasileiros e estrangeiros), mas me interessa, neste trabalho, enfatizar os aspectos comunicativos da cena musical per se, que criavam condições para outras formas de se fazer política a partir da cultura e possibilitavam novos exercícios estéticos que criavam novas condições de 
se estar no mundo. Nossa proposta, pois, é compreender a cena black soul não na sua relação com o movimento negro, mas em sua inserção no debate público a respeito da identidade brasileira, partindo da perspectiva de que a cultura popular é a base valorativa da atividade ético-política, ou melhor, das micropolíticas de representação cultural. (HANCHARD, 2001)

É importante salientar que o mapeamento da Black Rio e a cartografia das políticas de estilo configuradas a partir desse território musical, de forma alguma, esgotam todo o universo de sentidos que emergiram dessa cena musical. Tampouco me propus a analisar todos os produtos midiáticos disponíveis que podem ser relacionados à cena. Infelizmente, não foi possível, por exemplo, enfocar com profundidade a ação das mulheres negras nos bailes, narrar em detalhes a história de vida de figuras-chave do movimento ou, ainda, analisar particularidades das equipes de som mais importantes, cujas engrenagens de funcionamento, tipos de equipamentos e tecnologias utilizadas - em um estudo dos aspectos ligados às materialidades dos objetos comunicativos - poderiam revelar dados sobre a economia dos bailes. Espero que trabalhos posteriores possam expandir a compreensão desse fenômeno. Mas acredito que os materiais coletados e analisados, bem como os depoimentos recolhidos e a interpretação geral do contexto cultural da época, foram recursos suficientes e bastante representativos que poderão auxiliar na compreensão e problematização da atmosfera da cena e da formação de uma sensibilidade que propôs novos significados para a negritude brasileira naquele período.

No capítulo "Cenas musicais e estilos”, voltarei-me para a reflexão sobre a noção de cena musical, realizando uma revisão conceitual dos principais textos da área de scene research, cujos principais aspectos teóricos são acompanhados por uma discussão acerca de procedimentos metodológicos utilizados por diversos autores para a apreensão dos sentidos e dos processos de mediação constituídos a partir do consumo cultural da música popular massiva em um dado território. Nessa parte, tentarei ampliar as reflexões sobre cenas musicais, propondo uma visão desse espaço como locais de manifestação de afetos e da diferença cultural, concretizada nas políticas de estilo, cuja discussão se ampara, principalmente, na proposição de Hebdige (1979) a respeito dos estilos juvenis subculturais. 
No capítulo seguinte, "Bailes e clubes de subúrbio", a fim de compreender os antecedentes históricos e sociais da emergência dos bailes de subúrbio no Rio de Janeiro, o objetivo é explorar as transformações empreendidas na cidade desde o começo do século, enfocando especialmente a constituição dos subúrbios como espaços de mediação de gêneros musicais populares periféricos e de configuração de sociabilidades alternativas. As festas populares, a vida noturna, os espaços de dança e os clubes sociais ou sport clubs se mostraram locais privilegiados para o exercício de novas subjetividades e para trocas e intercâmbios de informações e referências ligadas à contemporaneidade, funcionando como espaços de filtragem e de acesso a uma cultura internacional. Esses bailes populares, locais fundamentais de lazer, criatividade e ludicidade, funcionavam também como espaços de negociação, potencializando encontros e o convívio comunitário, bem como trocas intersubjetivas que estabeleceram um idioma para a vida social e cultural do Rio de Janeiro.

No capítulo "O movimento", será realizado um mapeamento sobre o "movimento" Black Rio, enfocando os processos comunicativos que envolveram etapas ligadas à produção, circulação e consumo dos gêneros musicais do soul e do funk no Brasil, mais exatamente, no Rio de Janeiro. Esse capítulo se encontra dividido em quatro seções. Na primeira, realizarei uma revisão bibliográfica sobre os estudos mais importantes produzidos que abordaram o black soul em diferentes regiões do país, de diversas áreas do conhecimento. A ideia é contextualizar o objeto de pesquisa e mapear as reflexões anteriormente produzidas a respeito do fenômeno, buscando estabelecer paralelos que permitam localizar sua importância em relação a outras produções culturais. Em seguida, explorarei mais detalhadamente a configuração da própria cena musical de soul music no Rio de Janeiro, enfocando a realização dos bailes, a trajetória dos DJs e de produtores mais famosos, bem como a atuação das equipes de som. Na terceira seção, abordarei a introdução da música soul na indústria fonográfica brasileira, compreendendo como o gênero passou a ser explorado pelas gravadoras e pela mídia nacional, o que foi responsável pela maior difusão do movimento e por sua expansão para outras cidades brasileiras. Na última parte, com a finalidade perceber como a Black Rio era vista por alguns setores da sociedade, utilizarei como base críticas musicais, editoriais e reportagens publicadas em jornais e revistas da época e também 
investigações realizadas pela polícia secreta do governo militar, como forma de compreender como vertentes opostas da vida política nacional enxergavam as atividades ligadas aos bailes soul.

Nesse sentido, nota-se que havia uma dificuldade de compreensão pelos setores ligados à esquerda e à direita em relação ao movimento Black Rio, que ora acusavam os blacks de imitadores e colonizados, ora os consideravam racistas e segregacionistas. Os participantes do movimento ainda eram vistos como alienados, substituindo a união das classes ou a reverência às tradições brasileiras pela valorização do lazer, da festa e do consumo. Muitos movimentos culturais juvenis desencadeados a partir dos anos 1970 foram caracterizados como alienados por não adotarem modelos de intervenção política semelhantes aos empregados pela geração da década de 1960. Para uma parcela da crítica dessa época, essas novas manifestações eram esvaziadas de significado e moldadas pela indústria cultural, descritas como limitadas "[...] a um posicionamento individualista que não apenas impediria uma visão crítica da sociedade como também impossibilitaria a formulação de qualquer projeto de mudança social”. (HERSCHMANN, 2000, p. 57)

No capítulo "Blacks sob vigilância", o objetivo foi compreender como se desenvolveu o estilo da Black Rio a partir da materialização dos usos sociais da música no interior e para além da cena musical, que mobilizou aspectos ligados à recepção e à emergência de novos atores no contexto social. $\mathrm{Na}$ discussão da configuração do estilo, considero alguns critérios principais ligados às dinâmicas da globalização cultural, que estimularam o desenvolvimento de estratégias de reconversão cultural (YÚDICE, 1997) a partir da formação de uma cultura cosmopolita periférica (PRYSTHON, 2004), que se relacionava à ascensão de uma classe média negra nos anos 1970. Nesse ponto, é importante frisar que a escuta da música, na conformação dos estilos, passa por uma incorporação das sonoridades e dos discursos propagados pelo gênero musical. Para fins metodológicos, elencarei alguns aspectos que compõem o estilo, chamando a atenção para as principais plataformas de sua manifestação, como a moda, as imagens ligadas ao cinema e os usos políticos do cabelo, recursos estratégicos utilizados para estabelecer novos exercícios para a identidade negra. Assim, tentarei compreender como o estilo da Black Rio pôde oferecer uma terceira via e uma alternativa de manifestação cultural 
e política, por meio do corpo, do consumo, do lazer e de novas formas de sociabilidade.

O capítulo "O estilo da Black Rio" foi destacado, mas ainda equivale a uma das etapas de apresentação do estilo e se refere à música propriamente. Nele, analisarei um dos discos mais relevantes lançados em meio ao movimento Black Rio, uma coletânea de canções soul assinada pela equipe SGP de 1976 que atingiu altos índices de vendas. Nessa parte, aproveitarei para discutir aspectos ligados à gênese do soul nos Estados Unidos da América (EUA) e à forma como a música estruturava as performances da dança que marcou os bailes black cariocas, se incorporando ao repertório da cena musical. A partir desses parâmetros, a proposta é compreender o estilo nessa cena musical que, como diz Hall (2003, p. 342), "se tornou em si a matéria do acontecimento", utilizando a música como estrutura profunda da vida cultural e o corpo (e a performance) como capital cultural de novas representações.

A lembrança mais presente nas memórias da juventude da minha mãe eram suas idas aos bailes, entre fins dos anos 1960 e começo dos 1970. Não só dela, mas de grande parte das minhas tias e primas mais velhas que, como ela, são mulheres negras e pobres que encontraram no trabalho doméstico a única alternativa de sobrevivência naquele tempo. Os bailes em clubes suburbanos, periféricos, representavam para essa população uma das poucas alternativas de entretenimento nos finais de semana, dentro de um contexto de adensamento urbano e capitalismo tardio. A distância dos centros da cidade, dos equipamentos culturais, e o baixo poder aquisitivo ajudava também a estabelecer um circuito paralelo de entretenimento popular mais barato e acessível para essas pessoas. O parco acesso aos produtos globalizados de consumo se dava por meio da música, da dança, das novas sonoridades e modas que invadiam o cotidiano dessas pessoas, ainda que lateralmente, nas margens. Minha mãe não frequentava os bailes black, propriamente, mas dançou muito ao som de cantores negros que contribuíam para a configuração de uma rede alternativa de bailes e shows em regiões periféricas do estado e que se adensou, justamente, no momento da insurgência da Black Rio. Esse livro foi inspirado na minha mãe, nas mulheres da minha família, e é uma homenagem também a essas pessoas que imaginaram e deram corpo a esse movimento. 
Por meio da linguagem musical e performática do estilo, essa cena musical alcançou uma grande dimensão cultural e incentivou a difusão de novos símbolos e referências de ação coletivas, construindo uma produção alternativa e apontando para novas formas de sociabilidade. Quero, pois, propor uma reflexão a respeito de novas formas de vida social e diferentes políticas de identidade que implicaram a produção de representações contemporâneas da negritude diante do trânsito global de informações. Os estilos associados à cena musical da Black Rio geraram significados sociais e culturais distintos em nome da afirmação de uma diferença que subverteu estruturas de poder, oferecendo novas formas de acesso à cidadania por meio de ações lúdicas e criativas de consumo cultural, transformando a paisagem da cidade e apresentando outras formas de ser negro no Brasil. Convido os leitores a adentrar esse universo noturno de som, luz, suor e brilho, de batidas amplificadas estremecendo o globo espelhado. Segue o baile." 


\section{Cenas musicais e estilos}

A noção de cena musical tem sido bastante debatida no Brasil, especialmente na produção acadêmica de pesquisadores da área de comunicação. ${ }^{1}$ De fato, o conceito é egresso do próprio jornalismo musical e tem sido alvo de pesquisas importantes de teóricos dos estudos culturais (BAULCH, 2003; BERGER, 1999; KAHN-HARRIS, 2000; STRAW, 1991), que passaram a utilizar o termo como ferramenta conceitual em substituição à noção de subculturas ou de comunidades musicais. A ideia de cena foi desenvolvida no sentido de ajudar a interpretar um conjunto de práticas sociais, econômicas, tecnológicas e estéticas em torno do consumo da música popular massiva nos ambientes urbanos. (JANTOTTI JUNIOR; PIRES, 2011, p. 11) A noção de cena ainda aponta para "uma ambiência social, onde os objetos, ruas, clubes, bares, equipamentos, aparelhos, prédios e palcos formam um contexto material para as interações culturais entre indivíduos e grupos”. (TROTTA, 2013, p. 59) A cena musical, pois, pode ser uma importante ferramenta para a compreensão do consumo da música no ambiente urbano, indo além de questões restritas à sonoridade para abarcar territórios, circulação de produtos e sociabilidades.

1 Ver: Janotti Junior (2012a), Sá (2011), Freire Filho e Fernandes (2005) e Pires (2011). 
Outro ponto importante levantado pelas recentes discussões desenvolvidas no campo da comunicação a respeito da noção de cena musical refere-se a reflexões que se detêm sobre a relação entre cenas, consumo cultural e representação. A vinculação da cena musical a questões envolvendo processos de identificação tem sido frequente no Brasil, especialmente em trabalhos acadêmicos cujo objeto é o manguebeat. ${ }^{2}$ A discussão também tem apresentado outros desmembramentos mais recentes, em trabalhos que fazem referência às cidades e aos espaços urbanos a partir da ação de culturas juvenis que se estruturam em torno de práticas musicais, incluindo aí as comunidades virtuais e redes sociais, que trazem para a questão a ação das novas tecnologias de comunicação. Esse cenário evidencia a importância da ideia de cena acionada por diferentes autores na investigação de objetos variados. (BAULCH, 2003; BERGER, 1999; JANOTTI JUNIOR, 2012a; KAHN-HARRIS, 2000; STRAW, 2006) Esses trabalhos abordam as cenas musicais a partir das condições de produção e circulação midiática e mercadológica dos produtos musicais, enfatizando a ação cultural e o exercício estético de fãs, artistas, produtores e indústria fonográfica. Mas nem sempre privilegiam os processos de representação sociocultural e as dinâmicas subjetivas da experiência e do consumo musical, que podem agenciar sociabilidades e identidades culturais marginais e/ou alternativas.

Pioneiro no estudo das cenas musicais, Will Straw vem desenvolvendo importantes reflexões desde os anos 1990. Para ele, as cenas podem ainda se referir à reunião de pessoas em um lugar, bem como ao movimento delas, englobando diversos espaços e atividades realizadas ao redor de uma preferência cultural-musical específica, estabelecendo redes de atividades microeconômicas e sociabilidades que relacionam a cena à fruição da cidade. (STRAW, 2006, p. 6) Ainda segundo Straw (2006), as cenas também podem se referir a um fenômeno maior e mais disperso geograficamente, mas que se articula também em movimentos locais, como no caso do heavy metal, que possui variadas manifestações em diferentes regiões do globo. A circulação da música ainda pode incluir os fluxos on-line na configuração de cenas virtuais em

2 Ver: Ribeiro (2006) e Lima (2007). 
territórios informacionais, como no caso da comunidade de fãs de música eletrônica. (THORNTON, 1996)

O objetivo de Straw ao trabalhar com o conceito de cena era construir uma proposta interpretativa para a compreensão das práticas musicais na cidade, que transformam clubes, ruas, bares, praças e casas noturnas em territórios culturais demarcados por fronteiras geográficas e processos de diferenciação, materializando diversos envolvimentos afetivos e experiências em diferentes culturas musicais. O conceito de cena musical, até então, já era amplamente utilizado pela imprensa musical e foi sistematizado por Straw em trabalhos consecutivos como uma visão alternativa à ideia de subculturas urbanas, trabalhada por autores como Dick Hebdige (1979) e Paul Willis (1978).

Os estudos subculturais, apesar de oferecerem importantes contribuições à compreensão das dimensões estéticas da cultura popular juvenil, acabaram por deixar algumas lacunas na reflexão sobre formações de alianças afetivas vinculadas à expressão musical. Esses autores correspondiam à tendência acadêmica engajada dos cultural studies dos anos 1960 e 1970, cujas teorias eram marcadas por um compromisso crescente com questões políticas. O Centre for Contemporary Cultural Studies da Universidade de Birmingham, na Inglaterra, pretendia promover estudos e pesquisas interdisciplinares sobre novas práticas culturais com um viés neomarxista, com o propósito de "habilitar e encorajar os estratos subordinados a resistir à opressão e a contestar ideologias e estruturas de poder conservadoras”. (FREIRE FILHO; FERNANDES, 2005, p. 1) Nesses estudos subculturais iniciais, havia uma proposta de compreender esses grupos como uma manifestação legítima da vida juvenil, analisando como os estilos de vida, espaços territoriais e artefatos da cultura de consumo eram utilizados de forma crítica, espetacular e criativa diante das instâncias hegemônicas dominantes da sociedade. No entanto, essas visões passaram a receber críticas de novos autores a partir dos anos de 1990, que denunciavam o conceito de subculturas como algo datado diante da profusão de estilos, formas e práticas culturais contemporâneas, mais voláteis e movediças, esvaziando seu sentido original. A noção de subcultura também foi criticada por excluir de suas abordagens questões como raça e gênero, privilegiando a classe como aspecto central em sua definição. 
Outro problema do debate subcultural era sua falta de aprofundamento da discussão do próprio funcionamento do consumo musical na formação e desenvolvimento das culturas juvenis, o que poderia ampliar a reflexão sobre experimentações e configurações criativas das identidades, performances e linguagens.

Nesse panorama, a ideia alternativa de cena musical parece mais adequada, pois dá conta da formação das redes de lazer, gosto, criatividade e identidade que estruturam a relação entre as culturas juvenis e a música popular massiva, sinalizando para a importância do consumo cultural como uma via de construção de alianças que se estabelecem para além das tradicionais disputas por hegemonia. A noção de cena também assinala a coexistência de diferentes práticas musicais que interagem entre si, dinamizando variados processos de diferenciação e cross-fertilizations estimulados pela circulação global de formas culturais, como aponta Straw (1991), favorecendo a construção de novos valores, símbolos e gêneros musicais. É nesse contexto que a internacionalização pode produzir uma diversidade mais complexa, ao invés de impor uma homogeneização nas dinâmicas da música popular massiva. Não obstante, ainda é possível perceber certa coerência no interior desses espaços, ancorada justamente em um território, o que dá ao local geográfico privilégio na garantia da continuidade histórica de estilos, gêneros e práticas musicais (CARDOSO FILHO; OLIVEIRA, 2013), definidos tanto pelas ações dos agentes sociais da cena, como também pelos processos de subjetivação articulados às próprias fronteiras culturais. Portanto, para compreender as cenas em um sentido mais produtivo, é interessante percebê-las com processos que se desenvolvem e se reconfiguram na história, tomando corpo na sociedade de maneiras difusas, mas coerentes, a partir de interesses, práticas, compromissos, identidades e aspirações distintos.

Em suma, os estudos aqui elencados utilizam a ideia de cena a partir de alguns princípios norteadores, como a conexão entre cena e um território geográfico, como um bar, uma rua, um clube, uma discoteca; a cena vista como um território pautado pelo consumo cultural cosmopolita de gêneros musicais; e a cena como um espaço simbólico voltado para constituição subjetiva de processos de identificação cultural e performances de gosto. É também importante manter em vista a noção de que cenas musicais implicam fluxos 
desiguais de produção e circulação de artefatos culturais, formando segmentos paralelos e independentes, mas que podem estar em constante tensão com um mercado mainstream. Esses processos reflexivos que estabelecem e também são estabelecidos por relações, afetos e comprometimentos em torno da música, fluidos, efêmeros e variáveis, mesmo mantendo uma coerência em um espaço urbano, são ainda capazes de se repetir em outros locais, de outras maneiras, para além ou aquém de uma institucionalização que, por exemplo, o conceito de circuito cultural propõe. A ideia de cena musical aborda maiores complexidades, resultantes de deslocamentos dos sujeitos e repertórios culturais, cujas expressões são acionadas nos discursos, nos gostos performatizados e nos estilos, além do que no estabelecimento de redes concretas de circulação e consumo. Pois as cenas, enquanto redes complexas de lazer, solidariedade e sociabilidades, se constituem a partir da própria experiência de escuta e fruição musical e, enquanto topologia constitucional e semântica, correspondem às situações vividas em uma sociedade de consumo, marcadas pela cultura popular massiva e pelas constantes mutações inerentes a uma conjuntura globalizada.

\section{Cenas, identidades e consumo cultural}

As cenas musicais consolidam múltiplas alianças coletivamente a partir de experiências materializadas e valores compartilhados. Esse processo se configura mediante expectativas, sugestões e projeções que, mesmo que ainda não conscientemente percebidas, se tornam visíveis ao estruturar experiências anteriores, imprecisas, voláteis e dispersas em um espaço que institui novos horizontes de expectativa. A cena musical, pois, não se trata de um conceito que classifica uma experiência, mas ela própria cria experiências por meio da ação de seus próprios participantes, cujas experiências sensíveis determinam os sentidos particulares que emergem de cada cena musical, demarcando fronteiras de um autorreconhecimento dinâmico correlacionado a instâncias produtivas e atos reflexivos de consumo.

Nessas dinâmicas, música e identidade não estão isoladas e se materializam em territórios simbólicos que são configurados justamente por meio da performatização de gostos, valores e afetos. Afeto no sentido dado por 
Sovik (2009, p. 51), de abertura não verbal para o mundo, realizada na consciência dos sujeitos no entorno, que passa pela compreensão da realidade para além dos discursos e narrativas. É esse momento, quando "os relatos ainda não foram estabelecidos”, que torna mais potentes os relacionamentos, as ações grupais e o engajamento com o outro. Assim, entendo que as cenas musicais são fenômenos marcadamente cosmopolitas, pautados pelo consumo cultural e por estratégias simbólicas de diferenciação, em que seus participantes são constantemente afetados pela relação com os outros, com os objetos e com a sociedade, estabelecendo novas maneiras de relacionamento com a alteridade. Essas culturas de consumo da música efetivadas nas negociações e apropriações culturais, bem como em práticas de consumo mundializado, ampliam, pois, a própria noção de identidade cultural, não mais centrada em nações, línguas, fronteiras, desestabilizada por processos de migrações de pessoas, bens e símbolos.

Essa concepção de identidade cultural se refere a um constructo social de caráter relacional e contingente, que difere de um contexto para outro, expresso por processos individuais e coletivos de reconhecimento e autorreconhecimento. Nessas dinâmicas, são estabelecidas relações sociais e simbólicas, de valores e hábitos compartilhados por um determinado grupo. As identidades seriam, pois, dotadas de mobilidade, já que são constantemente afetadas pela história e pelas condições contemporâneas das sociedades, da mesma forma que pelas dinâmicas locais e globais. No entanto, como afirma Gilroy (2001), a identidade não é um conceito fixo e transcultural, pois mantém certa coerência no tempo e no espaço, sendo mobilizada de acordo com determinadas circunstâncias pelos indivíduos. Ao mesmo tempo, Hall (2003) aponta que uma identidade totalmente unificada e coerente é uma fantasia, pois ela é permanentemente confrontada pela multiplicidade de sistemas de significação e representação cultural. Assim, ela seria efetivamente determinada pelo conjunto de papéis que são performatizados nas interações sociais e também pelas condições decorrentes da produção da vida material, sempre em processo de mutação, da mesma forma que são todos os processos culturais, seguindo uma visão crítica da cultura.

Com efeito, o caráter móvel, híbrido e contingente das identidades nas cenas musicais já era apontado por Straw em 1991, numa conferência que 
deu origem ao artigo "Systems of articulation, logics of change". Nele, o professor canadense sistematiza a noção de cena musical e critica o conceito de comunidade utilizado por pesquisadores de estudos culturais, dotado de uma pretensa uniformidade. Straw (1991) defendia que as cenas inferiam em uma gama de práticas musicais projetadas sobre um território, conectadas à sobreposição de experiências subjetivas materializadas em torno da música. Havia também uma crescente influência, dentro da teoria cultural, que tendia a um engajamento em conceitos como território e nação. Uma preocupação que acompanhava as discussões em torno da autenticidade dentro dos estudos de música popular, mas que acabava por engessar as reflexões e o próprio conceito de identidade cultural.

Se as cenas musicais, como qualquer outra instância da cultura popular, representam zonas de tensão na definição de significados e valores não apenas musicais, mas subjetivos, elas inscrevem também diferentes formas de sociabilidade, solidariedade e processos dinâmicos de identificação em núcleos coerentes e particulares de atividade social e cultural. Aqui, a noção de identidade ou os processos de identificação oferecem um dispositivo interpretativo importante para pensarmos sobre as interrelações entre individualidade, comunidade e solidariedade. (GILROY, 2007, p. 123) As identidades são a chave para entender a interação entre experiências subjetivas e cenários histórico-culturais e são "construídas dinamicamente, dentro do grupo e na interação com os outros grupos, por meio de elaborações e reelaborações permanentes”. (DOMINGUES, 2009, p. 4) Já a noção de cena musical possibilita compreender a formação de espaços de ligação entre identidade, territórios, temporalidades contingentes e sonoridades, estabelecendo zonas simbólicas disjuntivas para populações deslocadas (minorias, imigrantes, colonizados), entrelugares de interseções e diferenças transitórias diante de culturas hegemônicas.

O consumo da música, nesse contexto, aponta para uma fundamental e profícua maneira de expressar a cidadania e a identidade, ao se recompor em circuitos desiguais e mutáveis de produção, comunicação e apropriação cultural. (GARCÍA CANCLINI, 2007, p. 137) As cenas musicais, entendidas aqui como fenômenos midiáticos que atualizam traduções e hibridizações criativas, “[...] ganham mais peso que os tradicionais locais na transmissão de 
informações e imaginários sobre a vida urbana e, em alguns casos, oferecem novas modalidades de encontro e reconhecimento". (GARCÍA CANCLINI, 2007, p. 159) O consumo musical, nessa esfera, ganha status de experiência social e apropriação coletiva de objetos mundanos que assumem novo valor, estruturando relações de solidariedade e distinção que deixam explícito um "exercício refletido de cidadania” (GARCÍA CANCLINI, 2008), especialmente em contextos de desigualdade e exclusão. Seguindo essa perspectiva, concordo que o consumo de bens, produtos culturais e informações comunicacionais tem oferecido mais respostas do que os meios tradicionais de representação política e que as abstrações das democracias claudicantes não oferecem, no contexto dos países em desenvolvimento, um instrumento suficiente e adequado para a superação das injustiças sociais.

Como parte de um fenômeno integrativo e comunicativo das sociedades contemporâneas, o consumo cultural afirma a "simbolização e o uso de bens materiais como comunicadores, não apenas como utilidades”, de acordo com Featherstone (1995, p. 121). Seguindo essa visão, o mundo das mercadorias, a cultura de consumo e seus princípios de estruturação são organizados em meio a tendências globalizadoras, centrais para o entendimento da sociedade contemporânea. O consumo, portanto, concretiza a manifestação de sujeitos e identidades que interagem entre si em uma experiência coletiva de apropriação e uso de produtos culturais em meio a diferentes processos sociais. $\mathrm{E}$ é na diversificação de gostos e estilos que se torna possível o acesso às bases estéticas que vinculam democracia à cidadania.

Na vida quotidiana, o consumo é moldado pela estrutura material e simbólica dos espaços geográficos, pelas desigualdades, pelos modos de vida, valores, estilos e também por transformações sociais. (MCCRACKEN, 2003) Os consumidores organizam as sociedades usando os significados dos bens de consumo para expressar categorias e princípios culturais identitários. O consumo passa a ser simbólico e destaca a dimensão social dos produtos e das ações de consumo, também promovendo relações entre indivíduos e experiências diversas. O consumo cultural é, assim, configurado por códigos e práticas do dia a dia que elaboram classificações, reafirmam diferenças e modulam comportamentos que estão em constante tensão com ideologias de mercado e estratégias interpretativas distintivas. 
Compartilhar identidade é estar vinculado fundamentalmente à formação de padrões de pertencimento, através de conexões subjetivas e alianças afetivas instáveis, movediças e contingentes. Essa partilha articula os sujeitos não apenas a uma unidade coerente - como ao território significativo da cena musical -, mas também cria vínculos interpessoais. Nesse sentido, apesar de não ser algo recente, o pensamento que conecta a identidade ao território pode ser também útil para a compreensão das relações de afeto e pertencimento que unem uma comunidade de fãs a uma cena. Essa ligação simboliza também a relação da consciência, da experiência e da sensibilidade com o território, que possui implicações políticas, culturais e sociais. A cena oferece, pois, um território para a afirmação de laços emocionais e afetivos, além de traços culturais divergentes e marginais que se concretizam em atividades sociais e em espaços de compartilhamento de afinidades e identidades.

A ideia de cena musical, desse modo, oferece um instrumento importante para compreender os laços afetivos entre indivíduos e a música e como essa relação transforma os espaços urbanos e contextos sociais. As práticas sociais de configuração e ocupação de territórios significativos engendradas nas cenas incluem os indivíduos nos processos de criação, distribuição e circulação musical, que envolvem relações sociais e econômicas. (PIRES, 2011, p. 4) Esses processos também são formulados a partir de manifestações da diferença, que ultrapassam hierarquias e binarismos fixos da alteridade, em estreita relação com uma reflexão ética sobre as identidades culturais, inscritas em processos contingentes, dinâmicos e instáveis de negociação.

As identidades culturais, longe de polaridades fixas, podem ser interpretadas como mobilidades reflexivas, câmbios e hibridações que criam formas diferentes de saberes alternativos, que se infiltram no discurso dominante e embaralham suas regras de reconhecimento. Em relação a essa dinâmica, Bhabha (1998, p. 165) propõe uma substituição da ideia de diversidade cultural pela noção de diferença cultural. Suas reflexões apresentam uma perspectiva da diferença enquanto processo da enunciação, que constrói sistemas múltiplos de identificação cultural a fim de criar um espírito mais produtivo da alteridade. A partir dessa perspectiva crítica, a compreensão da diferença cultural assume um caráter discursivo, visto que toda cultura é uma forma de atribuir significado a um mundo circunscrito em termos temporais e 
geográficos. Diante da negociação da diferença, o que está em jogo são tradições culturais e hábitos internalizados e cristalizados que, em instâncias mais profundas, constroem significados sobre as diferenças em territórios simbólicos. Assim, diferença e negociação caminham juntas e ultrapassam mecanismos simples de apropriação, já que o outro é da ordem do indefinível, do incomensurável, que negocia com as alteridades e se constitui "na estreita passagem do entrelugar do discurso do enraizamento e do afeto do deslocamento". (BHABHA, 2011, p. 153) O entrelugar, para Bhabha (2011), é o ponto de gestação e mutação de subjetividades híbridas, que negociam entre si em sua ambiguidade, contradição e ambivalência. É o limite epistemológico e fronteira enunciativa para uma gama de outras vozes subalternas na instituição de novas redes de poder, realçando a natureza performativa das identidades e da diferença e a negociação de espaços, fronteiras e limites da diferença, em instâncias como a classe, gênero ou raça.

De acordo com essa ordem performativa das identidades, a representação da diferença não se reflete em traços culturais ou étnicos preestabelecidos, inscritos em tradições fixas. Sua articulação social, especialmente em se tratando de minorias, passa por negociações e diálogos complexos e contextuais, mas que não retiram a legitimidade dos hibridismos culturais que surgem em momentos de transformação social e histórica. Essa relação instável e fluida entre identidades e entre espaços é o que nos permite compreender a cena musical em seu caráter movediço e permanentemente indeterminado por ciclos circunstanciais, próprios das mutações do espaço urbano. As cenas seriam fendas em territórios fronteiriços, pontos de encontro e também de desconstruções discursivas - uma espécie de "terceiro espaço" (BHABHA, 1996) - que conferem às produções culturais e identidades performatizadas nesse território sentidos nunca totalmente transparentes. Esse terceiro espaço é o espaço instigante e privilegiado da negociação cultural, lócus legitimamente gerador de hibridismos, que desconstrói "a fantasia da origem e da identidade fixa” (BHABHA, 1998, p. 106), negando ou recriando autoridades ao perturbar ordens estabelecidas pelas mesclas inconclusas e insubordinadas de subjetividades.

Recusando uma homogeneidade opressiva, essas vozes marginais fazem da diferença uma força cultural que legitima publicamente o caráter político 
de suas identidades, que estão fora do alcance da fixidez de tradições e estereótipos. Se o consumo deve ser compreendido como um sistema de significação que supre necessidades simbólicas, ele funciona, pois, como código a partir do qual as relações sociais e subjetivas são construídas. (ROCHA; BARROS, 2008) Dessa forma, o status simbólico e material dos produtos midiáticos pode ser uma fonte geradora de um código cultural para essas alteridades, estabelecendo alianças provisórias e, por vezes, contraditórias, com a finalidade de aumentar sua força reivindicatória dentro de processos permanentes, heterogêneos e mutáveis.

Assim, a cena musical apresenta-se, nessa perspectiva, como uma "comunidade cosmopolita vista como uma marginalidade” (BHABHA, 2011, p. 145), um ambiente de reconhecimento de diferenças negadas em outras esferas hegemônicas sociais e culturais. Ao mesmo tempo em que oferece um espaço para identificações afetivas, a cena musical é um território de travessia entre diversos meios sociais, local de encontros e experiências intersticiais que instauram um patamar intermediário entre o indivíduo e a sociedade. Atuando como espaço de celebração de alianças e sobrevivências de singularidades ligadas a memórias trans-históricas e estruturas representacionais, sempre provisórias. Nesse ponto, articulo o posicionamento de Bhabha ao conceito de estruturas de sentimento, de Raymond Williams, que reivindicava uma reflexão estética menos formalista e mais próxima da vida cotidiana. A discussão preliminar da ideia de estruturas de sentimento está em Marxismo e literatura (1979), em que Williams articula historicidade e cultura, pensando nas formas como surgem novas consciências a partir das rotinas, destacando um enfoque sobre os processos ativos dos sujeitos na produção do sentido. (CARDOSO FILHO, 2014, p. 73) É no cotidiano que os participantes das cenas musicais se articulam para tecer narrativas, construir novas ações culturais e estabelecer diferentes disposições afetivas. Nesse contexto, as cenas seriam constituídas também como espaços de experiências, memórias e afetos, estabelecendo novos valores para os produtos midiáticos à disposição. Essas experiências concretizadas no território ressignificam tanto os atos de consumo cotidianos quanto a própria vida nas cidades, de maneiras alternativas e criativas. 
Nessa proposta, as cenas implicam um sentido ético, direcionado para as condutas em sociedade, e dimensão estética, que constrói uma sensibilidade comunitária, em permanente negociação com seus variados atores. As cenas são assim compreendidas como fenômenos estéticos, pois moldam e são moldadas por afetos, valores, formas de sentir e de perceber o mundo. E são práticas expressivas dotadas de força política, porque o consumo cultural, as performances e os estilos podem "(re)posicionar os sujeitos em processos distintos de partilha, criando competências diferentes nas esferas públicas do cotidiano”. (CARDOSO FILHO, 2014, p. 75)

É importante, por isso, aproximar o estudo das cenas musicais e das práticas culturais de grupamentos juvenis à questão estética e política, o que pode auxiliar na compreensão de determinadas posturas de resistência e de formas de negociação de posições estratégicas, que configuram ações políticas tomadas por afetos e emoções. Esses aspectos baseiam as estruturas de sentimento que possibilitam o surgimento de novas consciências e estilos de vida, dotados de um explícito gesto político que torna público um pensamento e uma experiência sensível. E ainda dá sentido ao consumo de objetos simbólicos e à ocupação de um espaço que acompanha a própria formação de uma comunidade, utilizando a mídia e a música popular massiva como espaço fundamental de negociação de representações políticas e experiências subjetivas.

\section{Percursos metodológicos}

No conjunto dos estudos das cenas, é notável a frequência de alguns tipos de percursos metodológicos realizados por autores de diferentes áreas do conhecimento. Autores de diversas áreas utilizaram diferentes procedimentos metodológicos em seus estudos sobre cenas musicais. Para analisar aspectos identitários de grupos de ouvintes da música eletrônica contemporânea, Thornton (1996) fez uso da observação participante e da etnografia em clubes e bares. Com o objetivo de identificar características singulares de uma cena específica local em relação à expressão global do gênero musical, Cardoso Filho (2008) realizou procedimentos como a interpretação textual de produtos e performances a partir da análise semiótica de discos e/ou das letras de heavy metal. Já autores como Kahn-Harris (2000) se propuseram a 
produzir análises textuais articuladas à pesquisa das condições de produção e reconhecimento do gênero musical dentro da cena, bem como recorreram a traços biográficos dos músicos, seguindo uma perspectiva da sociossemiótica a fim de dar conta de traços sociais mais complexos, articulando dimensão textual quanto aspectos contextuais.

Em "Systems of articulation, logics of change", Straw (1991) deixou poucas indicações metodológicas a respeito de como apreender uma cena, privilegiando a construção de uma proposta interpretativa para a compreensão do termo que, segundo o autor, se remete à materialização de práticas musicais em um território cultural demarcado por fronteiras geográficas e de valor que contribuem para um envolvimento afetivo na cultura musical. Nesse texto, Straw comparou as cenas do rock pós-punk e da dance music, configurados por lógicas de transformação e sistemas de articulação entre contextos locais e globais. Na descrição das cenas, no entanto, o autor não apontava métodos específicos e, basicamente, as fontes nas quais fundamentou suas considerações foram compostas por textos teóricos específicos sobre música pop e por dados divulgados em publicações periódicas, como a revista Billboard ou The Wall Street Journal, fontes primárias disponíveis à época dos objetos de estudo trabalhados.

Harris M. Berger (1999) desenvolveu seu estudo partindo do pressuposto de que a música se caracteriza por possuir uma dupla natureza na sua prática: a experiência pessoal e a cena como um grupo social. $\mathrm{O}$ autor trabalhou tanto com os agenciamentos e ações dos sujeitos envolvidos na prática musical (intenções em expressar algo, ideologia etc.) quanto com os dispositivos sociais de regulação impostos pelo grupo social (como o tipo de bebida mais consumida, as regras de comportamento, a forma de dança). Nessa pesquisa, o autor, como observador participante, realizou três etapas metodológicas: uma etnográfica, na qual observava as práticas de sociabilidade dos integrantes da cena; uma etapa de descrição da experiência musical, tanto em seus aspectos de sentido quanto estéticos, para a qual Berger registrou shows e entrevistou músicos, buscando coletar mais dados sobre a relação que se estabelecia entre os ouvintes e a própria música; e um momento de análise da relação entre local e global dentro daquela cultura musical. 
Para Kahn-Harris (2000), o estudo da dicotomia entre local e global na cena de metal extremo foi efetivado a partir da análise da trajetória da banda brasileira Sepultura, enfocando mais especificamente a produção do álbum Roots (Roadrunner Records, 1996), no qual a banda traz referências sonoras, temáticas e linguísticas da cultura brasileira. Kahn-Harris recorreu tanto aos aspectos biográficos da banda quanto a análises de canções e das condições de produção, no início da carreira e no período de confecção de Roots, tentando articular tanto a dimensão textual quanto os aspectos contextuais que configuram a tensão local versus global na música da banda. Procedimento semelhante foi adotado por Janotti Junior (2012b), que retomou a análise das cenas musicais de heavy metal, tomando como objeto de estudo uma música também da banda Sepultura, "War for territory". Questionando as experiências que se sobrepõem nas diferentes mediações da vida social e da cena musical, o autor analisou letra e aspectos sonoros da canção, compreendendo-a como manifestação da tensão em torno da construção de alianças afetivas no território sonoro do heavy metal, também realizando entrevistas com músicos e críticos culturais.

No caso de cenas musicais distantes historicamente dos próprios pesquisadores, passadas, arcaicas e/ou residuais, mas com as quais ainda temos experiência de alguma maneira na cultura contemporânea, não seria possível a realização de etnografias ou observações participantes - outros métodos são empregados. Nesse caso, a análise textual de produtos musicais mostra-se um recurso interessante, da mesma forma que a pesquisa de outras instâncias que possam auxiliar na compreensão do objeto. Do mesmo modo, a coleta de narrativas orais cotidianas de pessoas que vivenciaram a cena permite revelar aspectos importantes do fenômeno. A interpretação de vestígios como artes gráficas, fotografias, produtos audiovisuais e informações disponíveis em material hemerográfico, que podem ser acessados em arquivos e bibliotecas, centros de documentação de jornais ou no acervo de algum colecionador ou amante do período em questão, podem servir ainda como contextualização das práticas musicais, e foram esses os recursos metodológicos de pesquisa acionados nesta pesquisa.

De maneira geral, há uma utilização frequente de métodos de pesquisa oriundos de campos como a etnomusicologia, a música, a história, a 
antropologia. Podem-se destacar pesquisas em comunicação da área de scene research que fizeram uso dessas ferramentas metodológicas, como Jacques (2007), que aborda o rock independente de Florianópolis, Fernandes (2007), cujo trabalho recai sobre a cena indie carioca, e Amaral (2009), que propõe uma etnografia da cena tecnobrega de Belém do Pará. A etnografia dá conta da descrição de eventos desencadeados no momento da observação, e o trabalho de campo pressupõe o contato direto entre entrevistador e entrevistado. No caso dos autores de comunicação que se utilizam desses métodos, no entanto, convém buscar algum diferencial ou especificidade em suas contribuições, a fim de enfatizar uma observação mais aprofundada sobre a ação dos diversos processos comunicacionais na análise das cenas musicais. Obviamente, diante da consolidação cada vez maior de uma prática multidisciplinar para os estudos sobre a cultura, é interessante que haja sempre um diálogo e intercruzamento de teorias, conceitos e práticas que podem se complementar e dar conta das múltiplas faces de um dado objeto de estudo. Mas aspectos comunicativos não devem ser isolados ou negligenciados.

Em nosso trabalho, a realização de entrevistas e pesquisa de materiais publicados à época em que o fenômeno se desencadeou mostra-se eficaz no sentido de reconstruir narrativas, compreender discursos de valor e gosto e perceber lógicas de formação de alianças e configuração de experiências subjetivas anteriores ao momento da pesquisa. Optei pela realização de algumas entrevistas abertas, que foram elaboradas com a finalidade de explorar impressões a partir de perguntas amplas, em que os entrevistados tinham liberdade para desenvolver aspectos e discorrer sobre fatos que fossem mais interessantes. A partir de diálogos informais, foi possível explicitar algum detalhe ou preencher lacunas sobre fatos específicos, captando nuances e comentários espontâneos. A opção por esse formato de entrevista pareceu o mais apropriado para a investigação de aspectos afetivos e valorativos dos informantes que participaram dessa cena musical, o que permitiu conhecer alguns significados pessoais, motivações, atitudes e comportamentos.

Minha proposta foi recuperar, mesmo que parcialmente, uma temporalidade e uma experiência conforme foi concebida pelos que vivenciaram a cena, suprimindo lacunas no processo de reconstituição histórica. Foi importante, para essa etapa, recorrer à documentação primária - correspondências, 
relatos e depoimentos públicos, registros institucionais, periódicos - e a fontes secundárias - escritos não contemporâneos aos fatos narrados, como textos acadêmicos, jornalísticos, literários e ainda comentários em blogs e sites de redes sociais. No que tange à pesquisa e ao resgate da experiência musical em contextos passados e/ou residuais, a pesquisa histórica permitiu lançar mão de informações presentes em documentos textuais, incluindo livros, fanzines, sites de internet e material hemerográfico tradicional. Também há a análise de documentos audiovisuais, como filmes, gravações caseiras, programas de TV, documentários, videoclipes e registros de apresentações ao vivo, que são utilizados como importantes fontes para enriquecer o entorno contextual, conferindo um maior aprofundamento à pesquisa empreendida. A análise textual ainda aparece como uma alternativa para oferecer pistas no processo de apreensão das cenas.

Como forma de inferir considerações a respeito da cena manguebeat em Recife na década de 1990, Lima (2007) analisou alguns discos específicos e canônicos dos grupos Mundo Livre S/A e Chico Science \& Nação Zumbi, levando em consideração as noções de performance e música popular massiva. Já Ribeiro (2006) utilizou referências encontradas em filmes como Blade Runner (1982) e obras literárias de ficção, em sua maior parte, da chamada ficção científica, como forma de construir uma narrativa historiográfica da referida cena mangue. Nesse caso, a literatura constituiu um dos elementos basilares do universo musical manguebeat, fundamental para o arcabouço das estruturas de sentimento da cena no que diz respeito à partilha de experiências, gostos e afetos comuns inscritos em dado território musical. (RIBEIRO, 2006, p. 33)

Tentei compreender como se dava a projeção de desejos e valores materializados em situações cotidianas e produtos musicais específicos relativos à cena musical da Black Rio. Esse método foi assumido como forma de mapear os sentidos que emergiram a partir dos bailes soul, observando também como possíveis expectativas foram geradas por seus participantes. Nesse sentido, tento perceber como se estabeleceram experiências estéticas que transformaram sensibilidades e moldaram afetos, da mesma forma que configuraram novas convenções, códigos e repertórios, cujos indícios ainda permanecem sendo reatualizados no presente. Nossa proposta, pois, se deu no sentido de 
desenvolver uma genealogia do movimento Black Rio, em uma espécie de história social dos processos comunicativos engendrados no interior e a partir da cena, a partir dessa experiência coletiva. Essa leitura parte de uma negociação com diferentes horizontes temporais, incorporando tanto interpretações atuais quanto questões que emergiram na época do seu desdobramento, como forma de interpretar as práticas acionadas pelos atores sem perder de vista possíveis sensibilidades cultivadas à época.

Ao propor esse estudo diacrônico, na apreensão de seus aspectos sensíveis, opto por interpretar os produtos da cultura popular massiva que se relacionavam à cena Black Soul, como filmes, discos, fotografias, panfletos e ainda publicações que circularam na época. A ideia é descrever a atmosfera sensível que emergiu dessa cena musical como forma de revelar aspectos da experiência em suas dimensões estéticas, históricas e comunicativas. Da mesma forma, debrucei-me sobre o conjunto de comentários críticos sobre a cena, entendendo esses discursos como reveladores das visões sociais e julgamentos de valor que são confrontados com reflexões atuais sobre dinâmicas identitárias e ideologias políticas, especialmente relativas à trajetória do movimento negro brasileiro. A partir desses vestígios selecionados, tento compreender como se articulou a cena musical aqui estudada e como ela originou um tipo de estilo que definiu novos parâmetros subjetivos e novos exercícios políticos e culturais, especialmente em um momento de polarizações e tensões na arena pública brasileira.

Para lidar com esses resquícios, Koselleck (2006) sugere a aplicação de duas categorias meta-históricas: o espaço de experiências e o horizonte de expectativas. O espaço de experiência se relaciona ao local da memória, às recordações, que remeteriam ao passado, localizados em um dado território simbólico - os bailes, o subúrbio, as ruas. Na experiência, fundem-se tanto elaborações racionais, discursivas, quanto comportamentos e ações cotidianas no âmbito individual e coletivo, "o que nos leva a crer que tanto em documentos institucionais (como livros acadêmicos e matérias de jornais) quanto nas narrativas subjetivas [...] podemos ter acesso a esse espaço de experiências impessoal”. (CARDOSO FILHO; OLIVEIRA, 2013, p. 12) Já o horizonte de expectativa, em sua dimensão pessoal e interpessoal, corresponde a projeções, previsões, desejos e também análises racionais do presente sobre 
algo que já aconteceu, e ainda sobre o que está por vir. Narrativas pessoais e produtos culturais massivos podem compor vestígios das experiências, dando conta das potencialidades estéticas e políticas que compuseram o repertório da cena musical e que abriram espaço para rupturas, inovações criativas e novas visões de mundo.

As experiências e expectativas podem ser modificadas com o tempo, e o confronto dessas duas instâncias permite desconstruir discursos que pretendam abordar "a realidade" ou "a verdade" sobre um objeto cultural, abrindo o olhar do pesquisador para perceber tensões, ambivalências e nuances que envolvem todo fenômeno cultural. Na captura dos vestígios da experiência da cena soul, as ações de consumo cultural e os estilos criados por seus participantes pressupunham modos específicos de organizar estrategicamente o tempo na construção reflexiva da autoidentidade. Nessa construção subjetiva, as projeções e desejos se voltavam para o futuro, mas também se baseavam em reinterpretações do passado, retrabalhando tradições e permitindo que os blacks dialogassem dinamicamente com diferentes temporalidades.

Assim, os estilos em jogo na cena da Black Rio deslocavam sua fixidez enquanto banco de "reserva" de significados, sentidos e práticas sociais. A observação dessa paisagem conduz o olhar para uma série de manifestações culturais e subjetivas, cujas estruturas serviam como base para a difusão musical, congregando agentes de suporte e de sustentação, ao mesmo tempo em que ofereciam um local de memórias e insights sobre a vida urbana na experiência da partilha da música. (GUERRA, 2011) Um espaço-problema alterado ao longo do tempo, reconfigurado a cada momento por seus participantes, que ampliavam e deslocavam os significados da cena.

Por conta dessa característica movente, os procedimentos metodológicos a serem adotados no estudo das cenas precisam dar conta da multiplicidade de tensionamentos e fissuras possíveis que podem ser instauradas tanto pela ação dos sujeitos quanto pela força situacional do contexto. Uma cena musical tem inclusive a capacidade de reorganizar as histórias e narrativas de sua gênese, criando novas alterações e fissuras (CARDOSO FILHO; OLIVEIRA, 2013), visto que as relações, representações e processos sociais apropriados por indivíduos não são transparentes. Eles estão envoltos em um senso comum que, simultaneamente, os valida e os mistifica. (HEBDIGE, 1979, p. 13) 
Por isso, os objetos culturais percebidos e aceitos como elementos detentores de um valor semiótico em um sistema de comunicação governado por regras semânticas possibilitam o acesso a códigos e discursos apreendidos tanto na experiência quanto na significação, marcadas por opacidades e ambivalências na produção de representações e dimensões ideológicas.

Observar as cenas com base em suportes midiáticos como discos, espaços, shows, publicações especializadas, bem como na forma como se dão os usos sociais dos produtos culturais por meio dos estilos, é uma forma de penetrar em uma economia de um imaginário coletivo (MARTÍN-BARBERO, 2008, p. 160), em que os processos comunicativos se estabelecem nos fluxos de impressões sensíveis e experiências subjetivas que permitem identificar modos de elaboração, tensionamentos e expectativas estabelecidas por diversas narrativas entrelaçadas. Por meio dessas narrativas, é possível perceber como discursos dos atores envolvidos - fãs, produtores, DJs, músicos, críticos - podem estar articulados à configuração dos gêneros musicais em torno dos quais se estrutura a cena. A própria materialidade da cena é dada pela ação comunicativa, apresentada em artefatos como discos, ilustrações, ingressos, banners, cartazes, fotos, fanzines e outros tipos de publicações alternativas produzidas por integrantes, usados como suporte para a circulação de valores, signos e códigos presentes dentro daquele contexto. Da mesma forma, os estilos que se desenvolvem no interior e para além das cenas é um fator fundamental a ser observado na compreensão do fenômeno. Os estilos engendrados nas cenas musicais possuem um grande potencial transformador e um poder político intenso, apresentando diferentes formas de construção da cidadania e estratégias de ocupação de um espaço público, oferecendo novas maneiras de existência social através do consumo da música.

\section{Os estilos em cena}

Na configuração dos estilos, os objetos mundanos possuem função principal e podem se converter em materiais simbólicos ao assumirem uma ação de subversão de ordens, instituições e fronteiras, assinalando e reorientando a presença da diferença. Os objetos também jogam com estigmas e são uma porta de entrada para a construção de sentimentos de pertencimento a uma 
comunidade alternativa. $\mathrm{O}$ estilo condensado nesses artefatos cria um inventário simbólico na definição de um ethos particular. A adoção de um estilo de vida implica escolhas estratégicas dentro de uma pluralidade de opções possíveis, rotinizando práticas e hábitos em termos de vestimentas, modos de agir, frequência em locais de encontro. Os estilos estão constantemente abertos a mudanças de acordo com a natureza móvel das identidades. "Além disso, a seleção ou criação de estilos de vida é influenciada por pressões de grupo e pela visibilidade de modelos, assim como pelas circunstâncias socioeconômicas" (GIDDENS, 2002, p. 81), reproduzidos e reelaborados diante de apropriações e de agenciamentos determinados nas relações com a sociedade e com o mercado.

Essa perspectiva segue proposição de Hebdige (1979) em seu estudo sobre as subculturas de teddy boys, mods, rockers, skinheads e punks. Por meio do estilo, esses grupamentos juvenis exibiam ao mundo suas presenças e desvios, utilizando determinados objetos cujo uso simbólico materializava marcas identitárias de valor contra-hegemônico, como cabelos, roupas, adereços e tatuagens. Hebdige dava prosseguimento às pesquisas desenvolvidas pelos teóricos do Centre for Contemporary Cultural Studies da Universidade de Birmingham, na Inglaterra, que pretendiam uma abordagem interdisciplinar para investigar estilos e atividades de diversos grupos juvenis no período pós-Segunda Guerra Mundial. Ao lado de obras como Resistance through rituals, de Stuart Hall e Tony Jefferson, de 1976, e Profane culture, de Paul Willis, de 1978, Hebdige figura com seu Subculture: the meaning of style (1979). Esse conjunto de textos tinha um claro objetivo de legitimar os modos de vida das subculturas juvenis por meio de análises textuais e trabalhos de campo etnográficos.

No estudo das subculturas, havia uma preocupação central em compreender como artefatos e práticas culturais específicas eram capazes de promover a aceitação de um status quo e dominação social ou de incentivar determinados grupos juvenis subordinados a resistir à opressão e a contestar estruturas de poder conservadoras. Assim, as subculturas consolidavam estilos emergentes que, mesmo pautados por hábitos de consumo e indústrias do lazer, também sinalizariam mais profundamente como respostas alternativas das culturas juvenis. Nesse sentido, os estudos subculturais pretendiam 
ir além de inventários de padrões de consumo, a fim de avaliar a função do uso criativo e espetacular dos artefatos da cultura de consumo como forma de desafiar instituições hegemônicas da sociedade.

No entanto, nos anos 1990, uma série de críticas foi elaborada em relação ao conceito de subculturas juvenis, especialmente diante da profusão de estilos, práticas, gêneros musicais efêmeros e também diante da grande oferta de artefatos de consumo, responsáveis pela volatilidade e hibridação constante das formações culturais no espaço urbano. Basicamente, as críticas incidiam sobre alguns aspectos, como o fato de que os pressupostos das subculturas não davam conta apropriadamente de temas como gênero e raça, privilegiando a centralidade das condições de classe na definição dos estilos subculturais. Outra corrente criticava a visão elitista sobre processos de consumo cultural por parte da juventude excluída da análise subcultural, vista como conformista ou passiva. Alguns autores também denunciavam a ênfase no estilo visual, deixando de lado aspectos relativos ao consumo musical, bem como a persistência de uma visão romantizada sobre a capacidade de resistência e o poder político das subculturas. ${ }^{3}$

Outra crítica que se pode fazer aos estudos subculturais é em relação à sua visão datada e bastante específica sobre um modelo de juventude - enquanto categoria sociológica -, de certa forma, bastante ocidentalizado e idealizado, cujos símbolos estariam presentes em um tipo específico de cinema comercial e em um formato de produção musical massiva. Essa juventude dizia respeito a um contexto social bastante específico, não sendo um modelo aplicável a outros cenários, épocas e sociedades. A visão subcultural do jovem baseada em uma suposta rejeição ao mundo adulto e à civilização burguesa, ainda que compreendesse o consumo como instrumento estético e lúdico para a fruição individualista e capitalista, em uma perspectiva ambivalente, mantinha resquícios de visões utópicas de vanguardas artísticas e de movimentos libertários, como o de maio de 1968, marcado pelo existencialismo do pós-guerra. A noção de juventude como algo homogêneo efetivamente vem sendo desarticulada desde então, diante de complexos fatores

3 Para uma revisão da crítica a respeito das subculturas, ver: Freire Filho e Fernandes (2005). 
sociológicos, demográficos e produtivos que têm tornado a "condição juvenil" cada vez menos estável e fluida.

Se a noção de subcultura como aporte teórico para a compreensão da relação entre jovens, músicas e identidades mostra-se, assim, insuficiente, creio que a proposta da noção de cena musical parece mais adequada por dar conta dos processos e fluxos globais e rearranjos locais híbridos em torno do consumo musical, mostrando-se também suficiente para a compreensão de afiliações e laços de afeto materializados sobre um dado espaço urbano, articulando o consumo a um potencial de crítica cultural. No entanto, parece-me ser ainda potente a relação entre consumo cultural e configuração de estilos no que diz respeito à performatização de gostos e de identidades que envolvem uma leitura diferenciada dos artefatos simbólicos que estabelecem novas sociabilidades.

Os estilos são, nesse sentido, respostas mediadas, como aponta Hebdige (1979, p. 80), conformadas em torno do gosto e da circulação da música, em que participantes das cenas musicais dramatizam, performatizam e constroem uma linguagem própria que demarca seus cotidianos e suas práticas culturais. Os estilos construídos dentro e a partir das cenas podem refletir fragmentações, ambiguidades e tensões cujas posições se alternam em jogos reflexivos e complexos. Como práticas significantes e codificadas, eles são compostos por elementos como música, iconografia visual, performances, roupas, estéticas e sistemas de valores (HEBDIGE, 1979), partilhados coletivamente, que se manifestam na configuração de processos identitários diferenciados. Essas estratégias que entrelaçam estética, performance, linguagem, sonoridades e discursos (OLIVEIRA, 2015b) implicam formas de negociação de posições, acionando diversas representações que estabelecem diálogos entre processos de subjetivação e condições de existência material, que dividem um mesmo tipo de linguagem e práticas significativas. Em relação aos estilos, Facchini (2011) ainda propõe uma articulação mais profunda entre estilos e performances como deslocamentos a partir de uma dramatização social.

Gostaria de argumentar, ainda, que os estilos não são produzidos por sujeitos pré-dados que agem de forma inteiramente consciente 
em relação aos efeitos a serem provocados pelas mensagens comunicadas por dada composição de aparência, atitude e música, mas que os sujeitos são constituídos no processo de citar e deslocar normas sociais, e isso pode se dar no processo de composição ou de encenação de determinado(s) drama(s) por meio do estilo. (FACCHINI, 2011, p. 146)

As cenas provocam, assim, a conformação de novos estilos em torno de um determinado território significativo. Nas roupas, no linguajar, na performance cotidiana ou acionada apenas durante a noite, o show, o baile, é possível perceber o engajamento dos estilos nas performances de gosto. Em seu texto "Pragmáticas do gosto", Hennion (2011) argumenta que o gosto é performatizado por meio de diferentes formas de vinculação, que envolvem dispositivos como tempo, espaço, regras e rituais, objetos e afetos, bem como o corpo e suas experimentações dentro de um cenário constituído a partir das condições midiáticas da configuração dos gêneros musicais. O corpo, particularmente, assume centralidade no estilo, por meio da aparência e da expressão de um controle e de uma construção ativa de uma imagem. Os estilos também implicam um gesto baseado na experiência sensível e provisória da vivência em um determinado espaço e nas sensibilidades e sensações despertadas a partir da escuta musical. Na materialização das performances de gosto, os estilos funcionam, pois, como rituais para a marcação da diferença, que enfatizam o caráter pragmático e performativo das práticas culturais, colocando em evidência a capacidade dos participantes de uma cena musical de transformar e criar novas sensibilidades. É Giddens (2002, p. 79) quem aponta a relação entre estilos e subjetividades, compreendidos como um "conjunto mais ou menos integrado de práticas que um indivíduo abraça, não só porque essas práticas preenchem necessidades utilitárias, mas porque dão forma material a uma narrativa particular da autoidentidade”.

Nesse sentido, o gosto seria uma modalidade problemática de conexão e engajamento no mundo, como uma atividade reflexiva, corporificada, enquadrada coletivamente, que produz simultaneamente competências e repertórios de juízos de valor. A natureza performativa do gosto e do estilo diz respeito, de tal modo, a estruturas coletivas, a materiais discursivos, à acumulação de sensações e à coleção de gestos derivados do ato da escuta e 
da fruição musical. Sua formação reflexiva se refere ao fato de que o gosto é formado no momento em que é expresso, e ele é expresso ao mesmo tempo em que se configura como uma espécie de tecnologia de apresentação de si. (HENNION, 2011, p. 263) O gosto ainda condiciona e é condicionado por signos sociais, por diversas origens históricas e culturais, por pretextos contextuais e rituais de prazer e felicidade que se articulam ao estilo, demarcando individualidades e formas de autoexpressão a partir daquilo que Herschmann (2000, p. 63) chama de uma "consciência de si estilizada".

É interessante pensarmos que, como disposições de identificação, os estilos formulados a partir dos gostos não são constituídos em cima de ações conscientes ou deliberadas. Eles surgem em meio a um conjunto de diversas formas de engajamento corporal não mecânicas, mas tampouco são naturais. Nesses atos performáticos cotidianos e repetitivos, há um condicionamento do gosto e um engajamento do corpo como uma construção social, submetida a normas e dispositivos culturais. As performatizações de gosto, assim, são atos reflexivos, pois imprimem marcas no corpo, que se constroem socialmente mediante interações extensivas com os objetos - no caso, musicais - e nas reiterações de gestos cotidianos que passam a ser internalizados e manifestos na apresentação pública dos estilos. Esses corpos, envoltos pelo estilo, são capazes de absorver sentidos e afetos pelo uso de objetos culturais, se mostrando habilitados para reconhecer o que outros corpos reconhecem (HENNION, 2011), compartilhando sensibilidades e identidades.

Na compreensão desse processo de compartilhamento de afetos, também é possível recorrer a Rancière (2005), cujo conceito de "partilha do sensível" é retomado por Janotti Junior (2012a) na compreensão da indissociabilidade entre estética e política no interior das cenas musicais. Na interpretação do sentido das cenas, os estilos, enquanto práticas significativas, se desenvolvem a partir da experiência coletiva do contato com a música, revelando processos de produção e recepção de afetos e significados, ampliando competências tanto pragmáticas quanto performativas. Eles são acionados no momento da interação, enquanto experiências estéticas, e confirmados na experiência cotidiana, enquanto proposição política. Pois é na "partilha do sensível", presente no cerne da própria ideia de cena, que há um compartilhamento de algo que é comum - a música, o espaço, a experiência, a escuta - de forma tensiva, 
que pressupõe uma participação, mas, ao mesmo tempo, uma individualização dentro daquela comunidade.

Giddens (2002, p. 81) entende que os estilos de vida se referem também à convergência e à pluralização de escolhas que dizem respeito aos domínios público e privado, e essas articulações estão caracteristicamente ligadas a ambientes específicos de ação - que podemos entender aqui como as cenas musicais. Os estilos expressam as cenas de onde se originam e suas configurações, muitas vezes, se referem a decisões dos participantes de se aprofundar nesses ambientes, materializando nos corpos, nos hábitos, na roupa e na performance nuances da cena conjugadas com suas próprias identidades. Se os estilos se referem a modos estratégicos de ação, eles podem ser modificados quando adotados em diferentes contextos e espaços. Mas mantêm uma razoável regularidade em seus modos de ação dentro de um grupo de práticas relativamente consistentes, que são ordenadas e encenadas em alguns momentos em contraste a outros momentos da vida diária. As cenas musicais, pois, oferecem um lugar seguro para a ancoragem de estilos de vida, especialmente ligados a padrões de consumo e comportamentos juvenis, conformando suas ações e encenações simbólicas.

Os estilos são também acessíveis a grupos menos privilegiados que passam a vivenciar realidades permeadas pelos componentes institucionais de uma suposta modernidade ocidental. Mesmo em situação de privação econômica e exclusão, os estilos adotados se mostram como maneiras diferentes de elaboração de sobrevivências e configurações reflexivas identitárias, afetadas pela globalização. Diante da mundialização, ampliam-se as alternativas de identificação, ocupando espaços em branco deixados pela tradição.

Essa justaposição se confirma na existência de um comum e de partes desse comum que estabelecem lugares e identidades culturais singulares, mas que compartilham espaços, tempos e ações que se retroalimentam dentro desse ciclo de partilha. Assim, esse modo simultâneo de dividir e compartilhar a experiência sensível comum é alocado à conjugação da política com estética, especialmente porque são os diferentes tipos de percepção que geram divisões e fronteiras em uma determinada realidade social. As cenas, dessa forma, proporcionam a inserção de novos atores na realidade das cidades e oferecem um local para a promoção de novas ações políticas e arranjos 
identitários que oferecem diferentes visões sobre o mundo, ao mesmo tempo que possibilitam novas formulações coletivas de visibilidade e existência social. Ao articular a ideia de estilo à proposição de uma espécie de cartografia social na configuração das cenas musicais, enfatizo o lugar da performance como manifestação móvel e deslizante das identidades em dados espaços e temporalidades, de acordo com as dinâmicas da experiência.

Tanto os estilos quanto as cenas musicais são ferramentas conceituais importantes que nos dão a oportunidade de apreender as atividades e exercícios subjetivos que se desenvolvem em torno da Black Rio, englobando desde instâncias produtivas à ação dos consumidores, permitindo a compreensão de seus significados para os sujeitos envolvidos. A cena da Black Rio, assim, pode ser descrita como uma atividade cultural que revelou dinâmicas sociais que se articulavam ao próprio processo histórico e social de urbanização da cidade do Rio de Janeiro. Nessa trajetória, políticas alternativas de estilo e atividades de entretenimento popular, especialmente no que se refere às populações negras, ajudaram a moldar o território dentro do qual essa cena musical se configurou, diante de ações criativas e marginais centrais para a criação de um senso coletivo de identidade. Para a interpretação da Black Rio, no próximo capítulo, enfocarei a descrição de contextos culturais e sociais que antecederam essa cena, como forma de compreender as condições prévias para a sua emergência, articulando essa cena a um longo trajeto de hábitos e costumes ligados ao lazer popular e à penetração de novos gêneros musicais na vida social da cidade. 


\section{Bailes e clubes de subúrbio}

Frente às múltiplas sonoridades que faziam parte da paisagem sonora do Rio de Janeiro na virada do século XIX para o XX, os gêneros musicais dançantes eram os mais popularmente difundidos, circulando entre os diferentes segmentos sociais nos diversos espaços da cidade. O lazer, a dança e as reuniões coletivas em torno da música popular, como bailes e festividades populares, ocupavam lugar central na vida social e cultural carioca. Músicas importadas da Europa e de países da América, como valsas, quadrilhas, polcas, mazurcas, tangos, habaneras e schottisches, ${ }^{1}$ marcavam presença tanto em aristocráticos salões e teatros da cidade quanto em espaços populares de divertimento, nas ruas e nas festas de família, tocadas por músicos de pouca formação musical. Essa importância estava representada na profusão de clubes sociais e de outros espaços criados especialmente para a prática da dança, muitos localizados em regiões populares desprovidas de maior infraestrutura e afastadas dos grandes centros e instituições da elite. Isso demarcava o poder da dança e dos bailes como fundamental elemento da vida social e amálgama

1 Tipo de dança campestre originária da região da Boêmia, na Alemanha, que se tornou bastante popular na Era Vitoriana, se tornando uma dança de salão semelhante à polca, mas com movimentos mais lentos. 
do estabelecimento de relações comunitárias e valores culturais periféricos já naquele período.

Herdeiros de uma lógica associativa que desde o século anterior alimentara a formação de associações mutualistas e irmandades religiosas, novos clubes se formavam a cada ano em todas as regiões com objetivos mais modestos, ligados ao prazer e ao senso de comunidade propiciado por bailes e demais festividades. (PEREIRA, 2010, p. 277)

Os bailes realizados nos clubes populares, além de despertar entusiasmo, se transformaram em espaço fundamental para a experiência social dos habitantes das regiões mais pobres da cidade, reproduzindo, à sua maneira, práticas de entretenimento da sociedade da época. Esses momentos de dança e celebração, realizados com mais assiduidade do que as festividades ligadas a feriados públicos e datas religiosas, como o Carnaval, se consolidaram como formas de lazer cotidianas tanto das elites quanto da vida dos estratos médios, fazendo também parte da rotina das populações moradoras dos bairros mais pobres. Essa maior demanda por divertimentos semanais aumentou como consequência do crescimento da cidade e da ampliação e diversificação das atividades urbanas, que ampliaram a oferta de emprego e simbolizavam uma forma de fuga diante de um cotidiano insatisfatório e mecânico do mundo do trabalho.

No final do século XIX, o Rio de Janeiro foi palco de um enorme crescimento demográfico, ocasionado pelo aumento dos fluxos migratórios do campo para as cidades, atraindo grandes massas de migrantes constituídas por escravos, ex-escravos e trabalhadores com ocupação mal definida, que eram os "excluídos" do Império. (OLIVEIRA, 2000, p. 139) Essas populações constituíram diversas comunidades, concentrando-se basicamente no centro da cidade e arredores, especialmente em cortiços e nas ainda incipientes favelas nos morros do entorno. No século XX, a cidade testemunhou uma intensa reorganização do espaço urbano motivada pelas reformas empreendidas pelo então prefeito Pereira Passos (1902-1906). A reurbanização teve como modelo as metrópoles europeias, particularmente Paris, e ocasionou 
uma reordenação do uso social do espaço urbano ao expulsar as camadas mais pobres da população para os bairros mais periféricos.

Essa reurbanização também tinha o objetivo de transformar a então capital federal no grande centro de diversões e produção artística e cultural do país (BESSA, 2008), o que era favorecido por uma rede de universidades, escolas, teatros, jornais e instituições do governo federal. Junto com a evolução das tecnologias de execução, reprodução e circulação musical, o Rio se tornou um polo de atração para a instalação de emissoras de rádio e, posteriormente, televisão, estúdios de cinema e sedes de gravadoras. O Rio, assim, se manteve não só como capital política, mas também como centro cultural do país, cujos encontros e diálogos entre diferentes grupos sociais criavam um espaço privilegiado para processos de miscigenação cultural, representando um modelo de identidade brasileira que se difundiu como o cerne da cultura nacional.

\section{O desenfreado das danças: bailes negros populares no século $\mathrm{XX}$}

Se já nas últimas décadas do século XIX, nas chácaras da Tijuca ou nos casarões de Botafogo, os senhores e senhoras promoviam saraus animados por valsas ao piano, polcas, xotes e quadrilhas - com pausas para refrescos, namoros, discursos e recitativos - na região central, especialmente na Cidade Nova, reduto da Pequena África, outras diversões ocorriam em "protoclubes" clandestinos estabelecidos em casas térreas de duas janelas e portas com rótula - os chamados “criouléus", anteriores às gafieiras. "Nesses arrasta-pés ou assustados se divertia a gente de baixa categoria social e econômica, predominando os pretos alforriados ou libertos”. (SAROLDI, 2000, p. 36, grifo do autor) Uma alternativa para uma população que não habitava em residências suficientemente grandes para a realização de festas domésticas. Assim, pequenos espaços voltados para a prática da dança e para a socialização coletiva passaram a ser criados, mediante entrada paga. Essas casas possuíam uma frequência basicamente negra e mestiça, composta por ex-escravos e descendentes que buscavam formas de divertimento e lazer mais baratas, localizadas nas redondezas dos seus locais de moradia ou em regiões centrais 
da cidade, de mais fácil acesso - especialmente em um tempo em que a circulação dos mais pobres era dificultada pela precária oferta de um transporte público. $^{2}$

A maioria dos “assustados”, que, segundo Jota Efegê (2009), eram bailes de "baixa categoria", estavam localizados na Cidade Nova. Neles, tocavam-se predominantemente os gêneros populares, como o choro, o sorongo, o arrastado, o gravanço e logo o maxixe, geralmente executados por conjuntos musicais amadores. Também alcunhados de sambas, os assustados se tornaram muito populares, porém possuíam má fama, sendo vistos como "centros de diversão onde a gente de baixo nível social dançava voluptuosamente o maxixe". (EFEGÊ, 2009, p. 23) Os assustados seriam uma etapa posterior dos criouléus do século XIX, locais populares de música e dança cujo próprio nome já denunciava a origem e composição étnica do público, criados na Bahia e trazidos para o Rio de Janeiro. Pouco tempo depois, esses espaços passaram a ser conhecidos como maxixes ou clubes de maxixe, famosos pelo "desenfreado das danças", sendo os locais de gestação do gênero popular de música e dança que logo tomaria de assalto a cidade.

Os clubes de maxixe - em sua maioria, clandestinos - eram vistos depreciativamente, considerados locais que atentavam contra a moral e os bons costumes, como denunciava Jota Efegê (2009, p. 25): “com muitos pares comprimindo-se em dança estabanada, rebolante, despreocupados da etiqueta e num agarramento antifamiliar”. Mas esse julgamento não impediu que, aos poucos, as sociedades carnavalescas e clubes recreativos - como o Clube Democráticos, Fenianos e Tenentes do Diabo, as três maiores sociedades carnavalescas da época - se rendessem ao ritmo. O maxixe era uma mistura da habanera e da polca europeias com o lundu africano, cujos movimentos eram baseados em meneios, movimentos circulares dos quadris e

2 Entre os salões da elite e os assustados, existiam outros formatos de entretenimento popular como as confeitarias e cafés, para os intelectuais e boêmios; as tascas, tabernas e quiosques frequentados majoritariamente por operários e trabalhadores informais; e as sedes dos cordões carnavalescos, voltados para a recreação e socialização de negros e mestiços pobres, como aponta Nei Lopes (2003, p. 17). Ainda havia outros formatos de entretenimento pago como os bailes de teatro, cafés-cantantes, cafés-concerto, circos e casas de chope, que já existiam na cidade desde a segunda metade do século XIX. (BESSA, 2008) 
umbigadas entre casais. Saindo do espaço dos assustados e clubes clandestinos, o maxixe chegou aos palcos dos teatros da Praça Tiradentes, cantado, dançado e tocado por grandes nomes do teatro de revista brasileiro, como Aracy Cortes e João Matos, que aprenderam os passos de dança com bailarinos populares (SAROLDI, 2000, p. 42), influenciando toda a produção musical popular da época.

Com o declínio do maxixe e o surgimento do samba, já na década de 1920, as gafieiras se espalharam pela cidade. Herdeiras dos assustados, também eram frequentadas por trabalhadores de baixo poder aquisitivo, negros e mestiços, além de malandros e prostitutas. Espécies de casas noturnas mais profissionais, nas gafieiras, eram realizados bailes com música orquestral de qualidade. A partir da década de 1960, tornaram-se um modismo e passaram a ter frequência mais eclética, incluindo pessoas da alta classe média. (LOPES, 2012, p. 162) Mas, de maneira geral, não eram espaços vistos com bons olhos pelas "boas famílias”, por conta da associação das gafieiras à marginalidade, aos vícios, à prostituição, bem como locais para concretização de enlaces extraconjugais.

Apesar das festas públicas e dos espaços das casas de dança serem espaços propícios à mescla de universos culturais, as manifestações populares e, dentro delas, o elemento negro sempre aparecem identificados com ideias de violência, criminalidade e periculosidade. (OLIVEIRA, 2000, p. 141) O negro seria uma "peça exótica" e perigosa, cujas manifestações deveriam ser combatidas ou neutralizadas pelo poder público. Mas a cultura popular sobrevivia, se esgueirando pelas brechas da cidade, demarcando espaços geográficos e simbólicos e tensionando suas dimensões em embates constantes com uma cultura de elite. ${ }^{3}$ Essa ideia era propagada tanto por autoridades

3 É digna de nota a "conquista" gradual pelos negros da festa da Igreja da Penha, até então uma celebração católica conduzida pela elite religiosa local e descendente de portugueses. Essa ocupação negra de uma das maiores festas populares da cidade recebeu atenções e reações contraditórias na imprensa, especialmente no tocante à forte repressão aos capoeiristas, que também frequentavam o evento, e ao sincretismo religioso ali praticado e mal visto na época. A história desse processo de ocupação negra da Festa da Penha se iniciou com a presença cada vez maior de baianas, que iam à festa vender seus quitutes aos frequentadores - Tia Ciata era uma delas, inclusive. Além das manifestações sincréticas que marcavam a festa, apesar da repressão, também eram realizados batuques que animavam o festejo. Aos poucos, a região do entorno da Igreja da 
policiais quanto pela imprensa e reproduzida pelos membros da classe média e elite, mentalidade que, como veremos no capítulo "Blacks sob vigilância", permenceu sendo reproduzida em relação aos bailes soul dos anos 1970. Mas, da mesma forma, não impediu o sucesso desses eventos entre as classes trabalhadoras mais pobres, cujos modos de lazer e fruição musical estruturaram formatos de entretenimento popular ao longo do século XX.

Essa construção de espaços geográficos e simbólicos demarcados por uma produção cultural negra e periférica não se dava de forma harmônica e pacífica. Havia tensões e conflitos que revelavam um processo de distensão e, ao mesmo tempo, de mesclas inconclusas entre uma cultura de elite e uma cultura popular, sendo que a primeira passou, paulatinamente, a beber da segunda. Esses trânsitos e diálogos se tornaram uma marca da identidade carioca e também da cultura nacional, complexificando relações raciais, questões de gosto e construções de valor na cidade. Sobre esse processo, aproprio-me da reflexão de Roberto Moura (2000, p. 153): "Assim, se um Rio de Janeiro era inventado ideológica e urbanisticamente pelas elites a partir de suas referências europeias, era reinventado pelo convívio daqueles com o povo apresentado por sua música”. Uma música popular que consolidava, transversalmente, uma cidadania marginalizada, constituída a partir de novas manifestações culturais que se configuravam durante a modernização da então capital federal.

\section{Uma nova cidade: desenvolvimento suburbano}

A Cidade Nova, região onde floresceram os primeiros momentos de uma cultura periférica de entretenimento carioca, foi irregularmente povoada após a expulsão da massa popular pelas obras de Pereira Passos. Essa "nova cidade" começa a se definir nas margens da área mais nobre e comercial do centro, "subindo pela Rua do Sabão até os arredores do Campo de Santana e da Praça Onze de Julho”. (MOURA, 2000, p. 122) A Cidade Nova também chegou até as favelas espalhadas pelos morros e encostas dos bairros da Saúde,

Penha se tornou ponto de encontro de sambistas famosos, como Donga e Pixinguinha, que, durante a festa, podiam mostrar suas composições e divulgar sua arte. 
Estácio e Mangueira, atingindo as circunvizinhanças dos pequenos núcleos de classe média no subúrbio. Um ponto importante dessa área foi a zona da Pequena África, que se estendia da região portuária à Praça XI, considerada o local do surgimento do samba. Foi na Cidade Nova que se estabelece, pela primeira vez, um espaço popular na cidade, mediante movimentos de ocupação e migração. O surgimento de novos padrões para a cultura urbana carioca tensionava noções de progresso e atraso, nacional e estrangeiro, autêntico e cooptado, gerando uma série de conflitos em torno das diferentes apreensões do que seria legitimamente popular. As festas populares e a música se tornaram um meio condutor dessa interpenetração, que também chegava aos subúrbios ainda em formação.

Naquele tempo, os subúrbios basicamente englobavam os bairros da Gamboa, Saúde, Penha e proximidades. Em uma nomenclatura mais antiga, o município do Rio de Janeiro era dividido em três zonas: a Urbana, que incluía o atual centro da cidade, a Zona Sul, dos bairros mais antigos, como Glória, Catete e Botafogo, e a região da Tijuca e arredores, áreas mais nobre ocupada por casarões e chácaras; a Zona Suburbana, que reunia os bairros da hoje chamada Zona Norte e bairros centrais mais pobres; e a Rural, depois denominada Zona Oeste, abrangendo toda a metade ocidental da cidade. Na linguagem popular, atualmente, o subúrbio engloba a Zona Norte, trechos da Zona Oeste e parte da antiga Zona Urbana, região central. Coloquialmente, a ideia de subúrbio assume um sentido de periferia, cujas conotações pejorativas possuem estreita relação com questões de classe e raça. Esta área, historicamente, congregava uma classe trabalhadora, mas também subempregada ou desempregada, mal provida de serviços, infraestrutura e opções de lazer. O subúrbio, assim, passou a ser visto como sinônimo de pobreza, inferioridade e atraso, a partir de uma ótica discriminatória.

Da mesma forma que a recente difusão do termo 'urbano', como sinônimo de cosmopolita e universal, é uma criação dos 'modernos' de hoje, a generalização da ideia de subúrbio como lugar carente, sem ordem nem conforto, habitado por pessoas pobres, sem educação ou refinamento, parece ser uma criação das antigas elites cariocas. (LOPES, 2012, p. 9) 
Essa separação da cidade em diferentes zonas também tinha relação com a proximidade de cada área para com o litoral. Quanto mais próximos do mar, mais importantes e valorizados, e esses bairros serviam, preferencialmente, como habitação para as classes mais altas e para a instalação de prédios públicos e centros administrativos e financeiros. Para Lopes (2012), a proposta de conectar o litoral das elites ao centro administrativo da cidade, especialmente durante a gestão do Pereira Passos, foi a razão da expulsão da população mais pobre do centro da cidade. Com a instalação de fábricas em áreas mais distantes do centro e, posteriormente, com a construção da linha férrea, essa população começou a se deslocar para os subúrbios, se concentrando ao longo da malha ferroviária. Desse modo, a expressão "subúrbio", às vezes usada no plural, passou a denominar toda a região residencial e industrial constituída entre a Serra do Engenho Novo, o Morro do Telégrafo, na Mangueira, e o morro do Retiro, Maciço dos Coqueiros/Retiro, em Realengo, acompanhando as linhas férreas que corriam em direção ao interior. (BERNARDES; SOARES, 1995, p. 98) A ocupação da Zona Suburbana carioca, portanto, pode ser atribuída às aglomerações formadas em função da atividade portuária/industrial, ao loteamento de fazendas para estabelecimento de moradias e aos agrupamentos habitacionais populares construídos ao longo das principais vias de acesso, como primeiramente as ferrovias e depois as rodovias. (PINHO, 2006, p. 175)

Nos anos 1960, a paisagem suburbana assumia um aspecto desordenado, com pouca infraestrutura e parco acesso a serviços básicos, mas acompanhada por uma urbanização acelerada e um aumento demográfico formado por populações de baixo poder aquisitivo. Essas pessoas ainda dependiam de longos deslocamentos por meio do transporte ferroviário e rodoviário para o centro e Zona Sul, onde se localizavam a maior parte dos postos de trabalho. A necessidade de fontes de consumo e serviços mais próximas acabou gerando subcentros comerciais em tradicionais polos suburbanos, como Madureira, Méier, Tijuca, Bangu e Campo Grande. Para Fernandes (2011), a palavra "subúrbio", na acepção mais moderna, não se referia, pois, à periferia da cidade, mas sim a esses bairros populares ferroviários e de intenso comércio, situados dentro do território da área urbana. Os bairros de Barra de Guaratiba, Barra da Tijuca, Grumari e Recreio dos Bandeirantes são pertencentes 
à Zona Oeste, mas, por sua proximidade ao litoral e por serem considerados bairros de elite por conta da história da sua ocupação recente, destoam dos demais bairros da região. Assim, na linguagem corrente e na imprensa, esses bairros passaram a ser incluídos na Zona Sul.

Já na administração de Carlos Lacerda (1961-1965), o Rio de Janeiro, agora ex-capital federal e atual capital do estado da Guanabara, possuía a mais elevada concentração demográfica do país (2.824 habitantes por km²), com uma população de mais de 3 milhões de habitantes, localizados, sobretudo, nas áreas urbana e suburbana. ${ }^{4}$ (MOTTA, 2000, p. 82) Apesar da perda de espaço em nível nacional, o parque industrial carioca era o segundo do país, com um claro predomínio de ramos ligados aos bens de consumo direto, como produtos alimentares, têxteis, vestuário e calçados. A transferência das atividades industriais para os subúrbios demandava a construção de grandes conjuntos habitacionais de apartamentos para trabalhadores e suas famílias. (MOTTA, 2000, p. 88)

Nesse período, o Rio passou por novas mudanças no espaço urbano. O governo Lacerda empreendeu projetos polêmicos, como a remoção das favelas da Zona Sul e a construção de conjuntos populares na Zona Oeste. Uma das marcas da ocupação do Rio de Janeiro são as muitas favelas instaladas nos morros localizados no coração da Zona Sul, e essas áreas nobres interessam ao capital imobiliário e à expansão da construção civil, favorecendo investimentos lucrativos e especulação. Havia também uma pressão por parte das classes médias em nome de um "progresso" e "bem-estar", e a remoção de favelas se tornou uma demanda de ordem pública.

A ideia de deslocar populações de baixa renda para longe das partes centrais da cidade não era nova, mas esse processo foi acompanhado por um decisivo alargamento da malha viária. A abertura de túneis - como o Santa Bárbara, ligando o bairro do Catumbi a Laranjeiras, e o túnel Rebouças, conectando o Rio Comprido à Lagoa -, a construção de viadutos e o aumento

4 Sua densidade econômica era igualmente expressiva, já que ocupava o segundo lugar no ranking dos estados da federação, vindo atrás apenas de São Paulo. Essa densidade se refletia na renda per capita do estado, a mais alta do país, com quase o triplo da média nacional. (MOTTA, 2000, p. 82-83) 
da oferta de transporte rodoviário contribuíram para uma ligação mais efetiva entre Zonas Norte e Sul. "O rodoviarismo resultante do modelo desenvolvimentista adotado pelo país exigia vias expressas mais rápidas”. (MOTTA, 2000, p. 89) O crescimento da área metropolitana carioca acabou sendo ocasionado muito mais pela própria expansão dos subúrbios e também da Zona Rural - que inclui desde Deodoro até Santa Cruz, passando por Campo dos Afonsos até Sepetiba -, do que pela expansão da parte central. Isso foi motivado pelo crescimento populacional nessas áreas mais populares, causado pelo intenso êxodo rural e pelo crescimento desordenado da população. Hoje, a ideia de subúrbio que integra o domínio público do Rio de Janeiro, mais do que uma denominação geográfica que compreende o norte da cidade, englobando bairros cortados pelas linhas férreas da Central do Brasil e da Leopoldina, se refere à sua oposição em relação à Zona Sul enquanto seu status social, sinônimo de pobreza, provincianismo e anacronismo. Para Souza (2003, p. 99), o subúrbio também representa um espaço de encontro entre o urbano e o rural, um local de idealização de relações pessoais e comunitárias mais fortes, bem como de preservação das tradições. É possivel, pois, pensar em uma identidade suburbana cujos atributos mais característicos podem ser articulados a uma maior comunicação interpessoal, laços de solidariedade mais coesos na proximidade das relações de vizinhança e amizade. A vida social comunitária no subúrbio, pois, seria idealizada a partir de uma maior qualidade e intensidade das relações sociais. (TROTTA; OLIVEIRA, 2015, p. 109)

Aos poucos, no lugar de estereótipos negativos ligados à ingenuidade, atraso e inferioridade, o subúrbio começou a ser percebido como fonte de novas linguagens, estéticas e modas, definindo outras estratégias de sobrevivência cultural e hábitos de consumo simbólico em circuitos alternativos de entretenimento, especialmente a partir do estabelecimento de clubes e de outros espaços voltados para o lazer e para a difusão de uma cultura popular massiva.

\section{Clubes e bailes de salão}

Consequência direta da instalação na cidade de um número expressivo de fábricas, os clubes tiveram um grande crescimento no começo do século XX, em vários bairros. Como espaços privilegiados para a prática da dança e 
atividades de entretenimento, os clubes passaram a marcar a vida social desde vizinhanças elegantes, como Botafogo e Catete, a subúrbios e bairros proletários, como Méier, Bangu e Madureira. A diferença residia no estereótipo da violência que era atribuído aos bailes suburbanos, eventos supostamente marcados por brigas, disputas e outras atividades tidas como imorais, relacionadas à prática de danças vistas como "lascivas". Mas, na verdade, os clubes suburbanos correspondiam a um esforço empreendido por seus sócios na criação de espaços de lazer e sociabilidade mais "respeitáveis", voltados para as famílias pertencentes a uma nova classe média baixa e estratos proletários que se desenvolviam e habitavam as redondezas.

Os clubes sociais populares surgem influenciados pelos sport clubs ingleses, criados no Rio de Janeiro após a instalação de companhias britânicas na cidade como a Light and Power, Bank of London, Leopoldina Railway, Western Telegraph, Rio de Janeiro Traction, entre outras. Os clubes abriam espaço para círculos sociais cujos membros e sócios, em sua maioria compostos por ingleses e seus familiares, se reuniam para atividades de lazer e convivência e também para a prática de esportes. O Rio Cricket, por exemplo, fundado em Niterói em 1897, era um clube de inverno voltado para a prática do cricket, onde trabalhadores britânicos confraternizavam e mantinham o elo com suas comunidades de origem. (LOPES, 2012, p. 103) Outros clubes voltados para o yatching e, principalmente, para ofootball também foram fundados nessa mesma época na Zona Sul do Rio, como o Botafogo, em 1894; o Flamengo, em 1895; e o Fluminense, em 1902.

Os clubes passaram a representar um espaço de convivência das chamadas "boas famílias" das elites, que se contrapunham aos supostos "maus elementos", cujos espaços eram as ruas e as zonas mais pobres. Com a expansão dos subúrbios, diante do aumento gradativo do poder aquisitivo de seus moradores, começam a ser criados clubes também na região suburbana da cidade. Em 1904, foi fundado o Bangu Atlético Clube por funcionários ingleses da Companhia Progresso Industrial do Brasil, a Fábrica Bangu. O bairro, por ter abrigado ao longo de sua história uma série de indústrias, cresceu diante da chegada de grandes massas de trabalhadores e se tornou um dos principais polos da Zona Oeste. No entanto, o Bangu Atlético Clube tinha um diferencial. Ao contrário dos outros clubes ingleses de futebol, a diretoria não se 
opunha à participação de negros na equipe e entre seus sócios, inclusive consagrando a instituição como uma opositora ao racismo no futebol. Outro clube da região, o Cassino Bangu, também ficou famoso por congregar a Sociedade Musical Progresso de Bangu, sendo visto como uma das poucas opções de lazer da população local. Em 1915, era fundado o Tijuca Tênis Clube, ${ }^{5}$ que se consolidou como opção de lazer para as famílias da região do Andaraí Pequeno e de outros bairros próximos da Zona Norte. Anos depois, com a mesma motivação, foi criada a Associação Atlética Vila Isabel, em 1950, por um grupo de militares de altas patentes. Um ano depois, foi criado o Renascença Clube, por uma classe média negra da Zona Norte, sendo primeiramente instalado no bairro do Lins, depois transferido para o Andaraí, com uma motivação diferente, voltada para a conscientização e valorização racial, como será visto no capítulo "O movimento".

Os clubes ofereciam um espaço mais adequado às "boas” famílias, cujos membros não deveriam frequentar gafieiras, dancings ou boates, por exemplos, tidos como locais frequentados apenas por classes mais baixas, voltados para um público "menos familiar", considerados locais favoráveis à prática da prostituição e de enlaces extraconjugais. Essa noção de preservação da moral e dos bons costumes advinda das elites passou a ser também reproduzida por estratos mais baixos de uma classe média proletária que buscava outras formas de entretenimento de acordo com seus status sociais nos pequenos núcleos de urbanização dos subúrbios. Os clubes suburbanos também se voltavam para a realização de festas e eventos sociais dançantes, geralmente voltados para a prática da dança em pares, ao som de gêneros musicais como o samba, a rumba e o bolero, suprindo uma necessidade de lazer e diversão mais moralizada. Os bailes eram de alta qualidade, animados por orquestras e conjuntos famosos e se tornaram eventos semanais frequentes que ganharam dimensão ainda maior com a difusão de outros gêneros musicais internacionais por meio do rádio e do crescimento da indústria fonográfica no Brasil.

5 Instituição emblemática por ter inaugurado a primeira piscina comunitária da Zona Norte carioca. Um fato histórico e social importante, levando-se em consideração a distância do mar, de acesso difícil, em uma época em que a comunicação entre as várias partes de uma cidade era bastante complicada, especialmente tendo em vista a pequena quantidade de vias de tráfego, um grande número de morros e pouquíssimos túneis. 
Lima Barreto afirmava, em crônica publicada no jornal Gazeta no ano de 1922, que os clubes do "pequeno povo", por não conhecerem danças norte-americanas como o foxtrote e o shimmy, populares nos salões das elites, organizavam seus bailes animados por gêneros populares "ultrapassados", ao som de pianos ou charangas. No entanto, mesmo nos bailes populares, sonoridades estrangeiras faziam sucesso ao lado de gêneros musicais brasileiros mais tradicionais. Um exemplo eram os bailes realizados em um famoso clube fundado por trabalhadores em Bangu, chamado O Prazer das Morenas. Segundo matéria "Prazer das Morenas de Bangu”, publicada no Jornal do Brasil, em 12 de janeiro de 1927, os bailes desse clube eram tanto um lugar da tradição (maxixes, sambas) quanto da modernidade, representada pelo jazz e foxtrote americano: “A barulhenta jazz-band 'Eu Não Disse?' não deu um minuto de trégua aos dançarinos, com os seus variadíssimos sambas e foxtrotes ultra modernos".

A tradição da realização de bailes de salões em clubes, agremiações ou associações de diversas origens é recorrente em todo o mundo, especialmente na América Latina, e se estabelece como hábito cultural decorrente da urbanização e do desenvolvimento da cultura popular massiva. O que chama a atenção para o estudo dos bailes cariocas suburbanos é a condição de serem marcados por uma dinâmica da contemporaneidade (PEREIRA, 2010, p. 280 ), concretizando práticas diferenciadas de consumo e valor social. Ao se aproximarem de um formato de entretenimento próximo ao proposto pelas elites, sem abandonar por completo tradições populares, acabaram por definir um novo modelo para o entretenimento popular na cidade, intermediado por hibridizações musicais com produtos internacionais. A diferença das instituições modernas ocidentais em relação às formas distintas de ordem social implicam novas dinâmicas, intervindo em hábitos e costumes tradicionais, modificando radicalmente a vida cotidiana ao afetar aspectos mais pessoais da experiência. E essa vivência da modernidade tardia, segundo Giddens (2002, p. 9), foi canalizada pelos meios de comunicação, influenciando tanto as alteridades quanto a organização das relações sociais.

A instituição dos clubes e agremiações foi transposta para as práticas populares, constituindo um longo e impalpável processo de comunicação entre diferentes grupos sociais, que auxiliaram a definir algumas das imagens 
associadas hoje à cultura carioca e, por conseguinte, à brasileira, marcada pelos diálogos e pelos intercâmbios de costumes e tradições ao longo do tempo. As associações recreativas se consolidaram como espaços de entretenimento cotidiano popular, visto que não havia grande oferta de espaços públicos de lazer nas áreas suburbanas. Nesse cenário, a música popular era um meio privilegiado de diversão (PEREIRA, 2010, p. 283), em que ritmo, dança e festa assumiam uma centralidade fundamental na experiência de sociabilidade das classes populares. Diante da necessidade de estabelecer novas redes de contato e vínculos comunitários, recriando tradições e absorvendo influências de outras culturas e grupos sociais, os bailes se apresentaram como filtros de uma cultura global e estabeleciam territórios significativos para a organização de suas proximidades e diferenças, importante em um contexto urbano marcado pela desigualdade social e racial.

As peculiaridades da experiência colonial latino-americana, a expansão demográfica, a maior participação popular na dinâmica urbana e a difusão do capitalismo contribuíram para a formação de novos estilos de vida, ainda no final do século XIX, o que implicou a adoção de formas aburguesadas de desfrutar atrações urbanas em modos de divertimento barato. "Certamente por esta razão, o dia não bastava, despertando-se desde então o gosto carioca pela vida noturna, em casa, no teatro ou no sereno da rua”. (LOPES, 2000, p. 10) Assim, a cultura do Rio se formou a partir de invenções populares e elitistas, do confronto ou fusão desses dois âmbitos, da cópia do modelo externo e da adaptação dessas influências na criação de linguagens e produtos originais, representando a vocação cosmopolita popular da vida carioca.

Consagrando-se como centro da vida política e cultural da nação, especialmente a partir da República, além de polo financeiro, o Rio de Janeiro projetou a autoimagem nacional, exercendo um poder difusor de modas, costumes e produtos culturais, também repercutindo os efeitos de seus movimentos sociais pelo resto da nação. (OLIVEIRA, 2000) Até os anos 1960, a cidade se manteve não só como capital política, mas também como espaço privilegiado de processos de hibridização e miscigenação cultural, representando um modelo de brasilidade que se difundiu como aquele que caracterizaria a cultura oficial nacional brasileira. 
O Rio de Janeiro, enquanto capital da República, representou a ponta estratégica da modernização do final do século XIX e início do século XX. A cidade possuía uma sólida estrutura de bens culturais, representados por teatros, cinemas, museus e bibliotecas, somados a uma rede de instituições educacionais, representada por universidades, centros e institutos de pesquisa, além de ser onde estavam localizados os maiores canais de TV, emissoras de rádio, estúdios cinematográficos e gravadoras. Mesmo assim, manifestações culturais populares não desaparecem e fortaleceram-se, justamente pelos contatos com uma cultura que vinha de fora. O samba foi o exemplo máximo que representou o ponto de encontro entre intelectuais, jornalistas e compositores populares, marcando o momento de embaralhamento de fronteiras entre brancos e negros, ricos e pobres, tradição e modernidade, cultura de elite e cultura popular. A adaptação de expressões locais se mesclava às estrangeiras, comprovando a capacidade da cultura popular de assimilar o externo. O surgimento de novos padrões populares tensionava, pois, noções de progresso e atraso, nacional e estrangeiro, autêntico e cooptado, gerando uma série de desvios e vetores de interpenetração.

[...] o tempo provaria que nem sempre as ideias dominantes são as ideias da classe dominante. A debilidade do projeto afrancesado das elites seria minada por um movimento subterrâneo e potente de abertura para valores miscigenados de cultura. Não é o caso de celebrá-los como valores de 'resistência' das classes dominadas, ou de alternativamente acusar a apropriação indevida de elementos 'autênticos' pelo poder. O fato é que só essa produção dialogizada de elementos interétnicos e interclasses foi capaz de lançar um projeto de identidade possível de ser aceito por amplos setores da população como sendo 'a nossa cara'. (LOPES, 2000, p. 28)

Os bailes dialogavam com diversos signos de distinção, que demarcavam territórios articulados a diferentes formas de estilo de vida e representações. O que estava - e ainda está - em jogo nas pistas de dança é a afirmação de identidades e da sua legitimidade, cujos elementos, valores e símbolos encenam uma estética cosmopolita e moderna, amplamente moldada pelo consumo musical massivo. Esses aspectos determinaram, assim, as bases da 
hegemonia de um modelo de entretenimento pautado pelo popular. Os bailes, em suas diversas manifestações, se instituíram como territórios simbólicos para o exercício de sociabilidades, dentro de um formato comunitário e criativo. A partir desses espaços identitários, é possível refletir sobre estilos e modos urbanos de vida, pois, como afirma Sevilla (2005, p. 184), os bailes expressavam, através do corpo (individual e coletivo), as dinâmicas sociais das cidades modernas. Quanto ao momento do baile, também por sua regularidade de realização e frequência, o que o diferencia das festas populares mais sazonais, por exemplo, reforça vínculos, marcas e códigos sociais, revelando novas linguagens e estilos, percebidos de maneiras distintas pelo restante da sociedade, mas que se tornam parte integrante das identidades dos participantes. Para Rocha (2012, p. 61), os bailes eram espaços de criação e manutenção das sociabilidades do grupo, "uma prática onde os agentes sociais podem reconhecer e reafirmar seus valores" e se convertem em local privilegiado de distinção, legitimando determinadas visões de mundo.

O desenvolvimento urbano a partir da Revolução Industrial gerou o surgimento de novas ofertas culturais nas cidades. Ampliaram-se as alternativas de divertimentos públicos e, aos poucos, o Rio de Janeiro testemunhava um aumento da demanda por eventos festivos por seus habitantes, pela gente comum que passava a celebrar sem comemorar em festas privadas, independentemente de qualquer outra razão que não fosse a do puro entretenimento e lazer. O desfrute coletivo da música e da dança, aos poucos, gerou os bailes de salão, tanto em bairros de elite quanto em regiões mais pobres. Dos assustados às gafieiras, chegando aos clubes suburbanos, a cidade presenciou uma crescente efervescência gerada especialmente por esse tipo de atividade. Se, em uma visão mais superficial, historicamente, os bailes formassem parte do patrimônio cultural das elites, como sinônimo de ricas festas, luxos e abundâncias, distinguindo a alta sociedade da "ralé", por conseguinte, as classes populares se apropriaram dessa prática para posteriormente construir seus próprios espaços de lazer. Primeiro, através de festas familiares ou comunitárias, para depois constituírem suas próprias redes de entretenimento, especialmente diante do desenvolvimento de novas tecnologias de comunicação, como a expansão do rádio e do mercado do disco, facilitando o acesso a 
produtos culturais internacionais, possibilitando hibridizações e difundindo novas modas e práticas de sociabilidade.

O baile, através da associação de sensações, escutas, performances e discursos, representa o tempo da emoção e do êxtase, que é efêmero. Mas implica uma experiência de aproximação e contato com o outro, durante um momento de partilha de vivências e trocas que podem fixar uma série de códigos sociais. A compreensão da dimensão dos bailes fornece uma via de acesso para a compreensão dos valores e relações sociais, pois eles representam um momento excepcional dentro da vida cotidiana, dramatizando diversas representações da realidade social, deixando em suspensão possíveis conflitos e desigualdades. Os bailes populares, ao absorverem a dimensão da festa, trazem o extraordinário para o cotidiano, catalisando com mais frequência os encontros e experiências performáticas e identitárias. Esses divertimentos públicos são fundamentais na manutenção da solidariedade grupal, incentivando a aproximação de indivíduos ao colocar as "relações sociais em estado de efervescência”. (COSTA, 2009, p. 70)

Durante a "interrupção" da vida social ordinária e do regime de trabalho, nos momentos efêmeros da festa, é possível realizar uma espécie de "renovação moral” que fortalece os laços de solidariedade grupal. (COSTA, 2009, p. 71) O baile marca uma atitude de transgressão perante a vida social, representando uma desagregação de uma ordem estabelecida, tanto através de excessos quanto por meio de contatos que recriam a realidade e têm o poder de revigorar a própria estrutura social.

A ruptura proporcionada pela festa [...] reside na descoberta dos sujeitos participantes da possibilidade de 'liberarem-se de si mesmos' e de enfrentar o mundo das regras de conduta e procedimento com a instauração de um tempo 'sem leis, nem forma'. Neste ponto, o sujeito da festa opera uma 'superação' da normalidade, de modo a identificar-se com um personagem imaginário numa comunidade imaginária, que exercita mecanismos que abalam as instituições normativas da sociedade. (COSTA, 2009, p. 71)

Do nosso ponto de vista, os bailes populares conseguiram reunir uma relevância cultural singular no tecido social carioca ao conjugar música e 
corpo, lúdico e erótico, lazer e exercício, o corpo individual e corpo coletivo. Além de funcionarem como um alívio contra as tensões originadas do cotidiano, especialmente em contextos de opressão e segregação, eles permitiam a criação de fortes vínculos identitários. Essas reflexões nos permitem compreender como os bailes soul dos anos 1970, em suas diferentes dimensões, imprimiram poderosos signos de distinção, na medida em que o corpo, a performance e o estilo manifestavam gostos e preferências de consumo, expressando a inscrição em variados tipos de pertencimento e afiliações sociais. Essas identidades concretizadas nas pistas de dança produziam estereótipos contrastantes, como jovem-velho, rico-pobre, negro-branco, nacional-global, mas também embaralhavam essas categorias ao possibilitar novos exercícios de diferenciação, que poderiam ser negados ou neutralizados em outras esferas. É dessa forma que os bailes funcionavam como veículo de expressão de associações sociais e se constituíam como territórios simbólicos.

As festas black estabeleciam redes de consumo, lazer e entretenimento guiadas pela música, que vinculavam a ocupação de espaços à proposição de novas representações socioculturais, que também eram políticas. Essas ações eram articuladas a práticas de consumo alternativas e marginais que, ao mesmo tempo, flertavam com uma cultura mainstream. Era por meio da dança e do estilo que os corpos comunicavam e se tornavam instrumentos de mediação e afirmação da diferença, reconfigurando uma cultura popular e negra. $\mathrm{O}$ consumo massivo associado a essas experiências de negritude incorporava uma possibilidade de representação da diferença cultural na qual os gêneros musicais assumiam uma função social e um papel simbólico em processos de disputas pelo poder. É Martín-Barbero (2008, p. 314) que diz que os gêneros massivos podem agir como uma espécie de mediadores sociais no interior da cultura popular massiva, em que atuam como modelos dinâmicos de negociação e estruturas de caráter social e ideológico, cujos códigos e convenções reconhecíveis por seus consumidores funcionam como portas de entrada para a produção de sentido e de identidades. Assim, a circulação da música na cena da Black Rio confirmava os bailes como expressões simbólicas da trama social, mas também como exercícios de novas expectivas, experiências e subjetividades, como discutirei nos próximos capítulos. 


\section{O movimento}

A quase totalidade dos textos jornalísticos, trabalhos acadêmicos e depoimentos públicos que abordam a memória do chamado movimento Black Rio se apoia na tônica da temática da busca, construção e afirmação de uma identidade específica, influenciada por uma cultura internacional. Uma identidade negra que se oporia fortemente à retórica do mito da democracia racial, como aponta McCann (2002), e cuja discursividade residiria sobre uma ideologia de resistência, altamente influenciada pelas proposições de alguns movimentos negros norte-americanos.

Não raramente, é possível observar o modo como diferentes autores de áreas diversas articulam as suas investigações na abordagem do fenômeno, que gira em torno da constituição dos bailes black como espaços de novas constituições identitárias afro-brasileiras. Nesse conjunto de textos acadêmicos "clássicos" que abordam a história do movimento Black Rio, perpassa-se a ideia de que o negro brasileiro, enquanto elemento étnico, para além do fenótipo, estaria em busca de uma identidade - não necessariamente considerada autônoma e autêntica - por intermédio de um processo de conscientização racial e combate ao racismo. Alguns autores ainda identificam a necessidade da constituição de uma produção cultural específica e legítima diante da apropriação pelo Estado do samba, do Carnaval ou de religiões de matriz 
africana na formatação de uma identidade nacional razoavelmente homogênea, apesar de conflituosa, retirando ou diluindo possíveis traços "negros" dessas manifestações. Assim, o também chamado movimento Black Soul seria uma resposta e reação a um suposto "assalto cultural" cometido pelo Estado e pelas elites brasileiras, permeado por influências de uma cultura global em consonância com a evolução dos meios de comunicação massivos. Seus principais participantes, portanto, acabaram por beber de fontes internacionais, notadamente da cultura negra norte-americana, como maneira de suprir uma "carência identitária".

Faz-se necessário mencionar que esses textos acadêmicos não se voltam exclusivamente para o estudo e análise do movimento Black no contexto brasileiro, mas abordam outras manifestações culturais das quais essa cena musical seria uma corrente convergente, uma etapa paralela a um processo mais amplo, ora em relação à própria formação do movimento negro brasileiro, ora como um momento embrionário de desenvolvimento de gêneros musicais como o funk carioca, o rap paulistano e o samba-reggae baiano, de certa forma, assumindo um lugar de dado contextual e aspecto coadjuvante. Poucos foram os trabalhos encontrados que tiveram o movimento soul como objeto central no conjunto das reflexões. A busca por referências, no entanto, revelou que, apesar da pouca atenção dada pela academia a esse objeto, alguns pesquisadores produziram reflexões preliminares à época do fenômeno ou em um momento imediatamente posterior, sempre articulando o Black Soul - em outras cidades do Brasil - à reorganização do movimento negro brasileiro e de uma consciência étnica em diferentes regiões do país na década de 1970.

Para Domingues (2007), o movimento negro no Brasil precisa ser definido de forma plural, englobando mobilizações de populações afrodescendentes em torno da resolução de questões sociais provenientes do racismo, da segregação e da marginalização na sociedade. Esses grupos instrumentavam a raça e a identidade étnico-racial em suas acepções simbólicas para mediar reivindicações políticas e articular a organização dos negros ao redor de projetos comuns de ação. Desse modo, os movimentos negros podem dizer respeito a entidades de qualquer natureza, como culturais, religiosas - terreiros de candomblé, por exemplo-, assistenciais, recreativas, artísticas - grupos de 
dança, teatro, capoeira - e culturais, como os centros de pesquisa e Organizações Não Governamentais (ONGs). Em termos políticos, desde o período pós-abolição, libertos, ex-escravos e descendentes criaram algumas entidades de mobilização racial, como grêmios e clubes em vários estados, como o Clube 13 de Maio dos Homens Pretos, em São Paulo em 1902, o Centro da Federação dos Homens de Cor, no Rio de Janeiro, enquanto no Rio Grande do Sul já havia sido criada a Sociedade Progresso da Raça Africana, em 1891. Essas associações negras tinham um mote assistencialista, recreativo e cultural e, por vezes, eram organizadas por classes de trabalhadores como portuários e ferroviários. Na mesma época, surgiam as primeiras manifestações de uma imprensa negra alternativa, cujos jornais eram voltados para a discussão de questões raciais e cujos títulos mais famosos eram produzidos em São Paulo. "Nesta etapa, o movimento negro organizado era desprovido de caráter explicitamente político, com um programa definido e projeto ideológico mais amplo”. (DOMINGUES, 2007, p. 105) Havia uma afirmação de viés mais cultural, de acordo com Pires (2015, p. 27), desde os anos 1930, a partir de um processo de articulação cultural que se opunha ao ideal de democracia racial estabelecido como uma espécie de "pacto político de contenção de massas”, que alocava práticas culturais de origem africana em uma posição subordinada a partir do caráter sincrético da contribuição dos negros à cultura nacional.

Nessa mesma década, foi fundada em São Paulo a Frente Negra Brasileira (FNB), uma das primeiras organizações negras deliberadamente políticas, com atuação em nível nacional, chegando a contar com mais de 20 mil associados. A FNB foi convertida em partido político, mas logo foi extinta em 1937, durante a ditadura do Estado Novo. Entre os anos 1940 e 1960, outras entidades foram criadas, além dos jornais da imprensa negra, mas sem a mesma força e amplitude e, apesar de alguns dirigentes terem sido eleitos para cargos públicos, mantiveram-se isolados politicamente. A exceção foi o Teatro Experimental do Negro (TEN), criado no Rio de Janeiro em 1944 e liderado por Abdias do Nascimento. ${ }^{1} \mathrm{O}$ TEN foi inspirado pela ideologia

1 Abdias do Nascimento (1914-2011) foi um dos maiores expoentes da cultura afro-brasileira, poeta, ator, escritor, dramaturgo, artista plástico, professor universitário, político e ativista dos 
da négritude, de Aimé Césaire e Léopold Senghor, e possuía grande vitalidade, desenvolvendo uma série de ações em defesa dos direitos civis da população negra, propondo a criação de leis antirracistas no Brasil. ${ }^{2}$ Como outras organizações negras, também foi desmobilizado durante a ditadura, sendo extinto em 1968 por ocasião do autoexílio de Abdias do Nascimento nos EUA. O governo militar também esvaziou outros movimentos que passaram para a semiclandestinidade, e só na década de 1970 que organizações civis e populares passaram a se reorganizar, incluindo a imprensa negra e o Grupo Palmares, de Porto Alegre (1971). No Rio de Janeiro, foi criado o Centro de Estudos Afro-Asiáticos (Ceaa) em 1973, a Sociedade de Intercâmbio Brasil-África (Sinba) em 1974, o Instituto de Pesquisas das Culturas Negras (IPCN) em 1975, mesmo ano de criação do Grupo de Trabalho André Rebouças e do Centro de Estudos Brasil-África (Ceba). Três anos depois, foi criado um grupo organizado político efetivamente, o Movimento Negro Unificado (MNU), entidade com uma pauta concreta de enfrentamento ao regime militar, de orientação majoritariamente marxista-socialista. ${ }^{3} \mathrm{E}$ tanto o IPCN quanto o MNU tinham uma ligação com a realização dos bailes soul no Rio e São Paulo, respectivamente, e era nas festas que muitas lideranças arregimentavam novos militantes.

Uma das primeiras reflexões acadêmicas sobre a ligação entre os bailes e a ação militante de negros foi apresentada em 1980, por Carlos Benedito Rodrigues da Silva, no IV Encontro da Associação Nacional de Pós-Graduação

direitos das populações negras. Atuou em movimentos nacionais e internacionais, como a FNB, a Négritude e o Pan-Africanismo, e foi fundador de entidades como o Museu da Arte Negra (MAN) e o Instituto de Pesquisas e Estudos Afro-Brasileiros (Ipeafro), além de ter sido posteriormente um dos idealizadores do MNU.

2 "A proposta original era formar um grupo teatral constituído apenas por atores negros, mas progressivamente o TEN adquiriu um caráter mais amplo: publicou o jornal Quilombo, passou a oferecer curso de alfabetização, de corte e costura; fundou o Instituto Nacional do Negro, o Museu do Negro; organizou o I Congresso do Negro Brasileiro; promoveu a eleição da Rainha da Mulata e da Boneca de Pixe; tempo depois, realizou o concurso de artes plásticas que teve como tema Cristo Negro, com repercussão na opinião pública”. (DOMINGUES, 2007, p. 109)

3 Essa não era necessariamente uma postura unânime da entidade, e havia divergências político-partidárias entre seus membros. Para um aprofundamento a respeito da história do movimento negro no Brasil, ver: Hanchard (2001) e Alberto (2011). 
e Pesquisa em Ciências Sociais (Anpocs), no grupo de trabalho "Temas e problemas da população negra no Brasil". O trabalho pioneiro intitulado "Black Soul: aglutinação espontânea ou identidade étnica” é uma análise do movimento Black deflagrado em São Paulo. Nele, o autor apontava a existência de modernas formas globalizadas de produções culturais negras para além daquelas de origem africana. Silva (1980) propunha uma análise do grupo Afro-Soul, sediado em Campinas e criado em 1978 por jovens negros interessados na realização de bailes de soul para um público também negro que não tinha acesso às festas e eventos de lazer promovidos em clubes tradicionais da cidade. $\mathrm{O}$ autor estava interessado em compreender se essa equipe de soul, enquanto representante de uma cena musical maior, tinha uma motivação mais voltada para os negócios e para o entretenimento, ou se haveria uma "[...] proposta mais concreta de conscientização do negro em busca de sua identidade étnica”. (SILVA, 1980, p. 2) Silva (1980, p. 2) partia do pressuposto de que o grupo Afro-Soul seria um exemplo de uma forma contemporânea de aglutinação étnica que tinha um "caráter de mobilização de elementos negros através da música” e também por outros elementos como roupas e danças, que emulavam uma forma de organização importante no processo de formação da consciência do negro em Campinas e, por extrapolação, em outras cidades onde ocorria fenômeno semelhante.

Para isso, o autor se atém a uma implicação local das atividades do grupo, mas sinaliza um dado interessante que pode ser incorporado em outras análises sobre a cena black no Brasil: a constituição de um conjunto de ações culturais promovidas por uma ainda insurgente classe média, ou mesmo de uma "elite" negra, que se configurava em alguns centros urbanos. "São pessoas que se pode dizer que conseguiram furar o bloqueio, tiveram acesso a um tipo de educação que a maioria da população negra não tem, e isso lhes atribui uma certa importância no meio negro”. (SILVA, 1980, p. 5) Além de um maior nível escolar, o autor aponta para uma articulação entre os principais integrantes da equipe com outros indivíduos e instituições socioculturais negras locais como associações beneficentes, grupos de teatro, órgãos de imprensa negra. Como apresentarei com mais profundidade no capítulo "Blacks sob vigilância”, apesar de uma grande maioria da população negra ainda permanecer no subproletariado urbano, após 1930, percebeu-se a emergência 
de uma pequena classe média formada por não brancos e a crescente incorporação de uma quantidade substancial de negros e afro-mestiços à classe trabalhadora industrial, que experimentou mais ganhos econômicos e sociais com relação às gerações passadas. Naquele momento, o sociólogo Hasenbalg (1979, p. 249) observava:

Contudo, devido a suas realizações educacionais mais elevadas e às formas de discriminação encaradas em seu movimento ascendente, este grupo está em melhor posição para visualizar a operação de mecanismos racistas. Com base nisto, é possível conceber este grupo como a principal fonte de liderança negra, tendo, de fato, as raras manifestações de não-conformismo racial durante as últimas décadas partido dos membros mais jovens e educados da classe média de cor.

Mesmo assim, para Silva (1980), como para outros autores, a preocupação das equipes de soul com o lazer seria maior que uma visão e uma proposta concreta de um movimento racial. $\mathrm{O}$ autor também considerava que a preocupação com a busca e a demonstração pública de um certo status alcançado por meio da integração em uma sociedade de consumo superaria possíveis interesses políticos: "Curiosamente, parece que os grupos acabam incorporando os padrões estabelecidos pela sociedade dominante, procurando serem reconhecidos como negros bem sucedidos”. (SILVA, 1980, p. 7) Esse desejo, para Silva (1980), também estaria representado no processo de ocupação de espaços anteriormente negados, como clubes frequentados apenas pela elite branca local, nos quais era vedada a entrada de negros. ${ }^{4}$ Essas inter-

4 "Mas, é preciso ver o que significa dar uma festa no Tênis Club, que e um dos mais conhecidos clubes da elite branca da cidade. Ainda que se utilize somente as quadras de esporte, essa situação aponta para a questão racial, na medida em que não estariam entrando no clube como um grupo qualquer, mas como um grupo de negros. Também significa ocupar um espaço que normalmente não lhe é permitido". (SILVA, 1980, p. 6) A situação da interdição da entrada de negros em espaços "brancos" da elite e da classe média de Campinas, conforme descrição em outras passagens do artigo de Silva, também era articulada à questão da classe social, como denuncia Assef (2003, p. 21) em relação ao contexto de São Paulo: "Ao contrário de países como os Estados Unidos, não havia no Brasil um código social que vetasse a entrada de negros nesses bailes. O fator excludente era mesmo o alto preço dos ingressos". 
dições parecem ter sido frequentes também no Rio de Janeiro, como lembra Oziléia Souza: "Na época, aqui em Volta Redonda, tinha um clube em que não podiam entrar negros, Clube dos Funcionários, e eu ficava indignada com isso". Em diversas passagens de seu artigo sobre a Black Rio, Lena Frias ilustra a questão ao transcrever o depoimento de um jovem negro de 17 anos, auxiliar de escritório:

O problema é o seguinte: em Mesquita tem dois clubes, o Mesquita Futebol Clube, que é da gente, e o Mesquita Tênis Clube, em que não entra preto. Eu fui querer entrar num baile no Tênis Clube, em janeiro, e não deixaram. Era um baile de conjunto. Eles disseram que a gente não podia entrar, criava tumulto. É por isso que nos bailes Black não tem White. (FRIAS, 1976, p. 5)

Havia, por esses jovens negros produtores e frequentadores, um maior cuidado com a apresentação, enfatizando um "bom comportamento", a criação de uma atmosfera não violenta de qualquer ordem, a respeitabilidade, imagens distantes das atribuições estereotipadas tipicamente relacionadas ao elemento negro. Esse desejo de transmitir uma imagem diferenciada também residia na questão da aparência, como forma de garantir o seu reconhecimento como "negros de bem". (SILVA, 1980, p. 12) Mesmo assim, para o autor, esses dados não apagariam o sentido de mobilização presente nesses eventos festivos: "[...] o fato dessas pessoas serem negras em sua maioria, e estarem reunidas em um mesmo lugar, ainda que por algumas horas, pode ter um sentido de resistência, e um significado importante para a conscientização do negro". (SILVA, 1980, p. 13)

Apesar de não avançar muito mais nas reflexões a respeito da importância dessa cena Black Soul e em suas implicações político-culturais, Carlos Silva levanta algumas questões pertinentes como o motivo da escolha da música norte-americana como amálgama de uma "aglutinação étnica" dos negros brasileiros. Uma das possíveis razões, um tanto holística, era de que o soul,

5 Babá e frequentadora dos bailes. Entrevista concedida à autora por telefone, Rio de Janeiro, 26 abr. 2016. 
em relação ao samba e a outros gêneros musicais afro-brasileiros, representava uma música que possuiria uma "força interior maior", explanação que deixo de lado neste momento por uma falta de sustentação teórica. Mas me atenho a uma outra justificativa dada por Silva (1980): a de que a black music, em geral, simbolizaria uma possibilidade de "ascensão social”, representada pelas imagens de seus principais artistas, que ultrapassava fronteiras nacionais e chegava a uma população marginalizada. O soul era a trilha sonora da luta contra o sistema racista presente na sociedade norte-americana, compreendido pelos adeptos da democracia racial como mais severo e mais grave que o racismo brasileiro. Naquele momento de maior conscientização e mobilização entre as populações negras brasileiras, esse gênero musical pareceria, pois, mais adequado a um acirramento das discussões em relação ao preconceito racial - ao menos, mais pertinente do que o samba, já apropriado pelas elites e outras camadas da população, o que teria levado ao seu "embranquecimento".

A respeito do conceito de democracia racial brasileira, Abdias do Nascimento (1978, p. 41) já denunciava a irrealidade contida na máxima de que negros e brancos conviveriam "harmoniosamente, desfrutando iguais oportunidades de existência sem nenhuma interferência, nesse jogo de paridade social, das respectivas origens raciais ou étnicas”. Para o autor, esse argumento ocultaria um racismo característico do Brasil, eficazmente institucionalizado nas estruturas mais profundas da sociedade e "difuso no tecido social, psicológico, econômico, político e cultural da sociedade do país”. (NASCIMENTO, 1978, p. 93) Domingues (2005, p. 2) argumenta que a democracia racial, "a rigor, significa um sistema racial desprovido de qualquer barreira legal ou institucional para a igualdade racial, e, em certa medida, um sistema racial desprovido de qualquer manifestação de preconceito ou discriminação”. Ela se configura como mito de acordo com o que Barthes (2009) propõe, pois o mito é um sistema de comunicação que transmite uma mensagem, um modo de significação originário de um contexto histórico e de condições de funcionamento a partir de constantes reinvestimentos da sociedade. Assim, o mito não necessariamente é uma verdade ou uma mentira: ele é um discurso que não se define pelo objeto da sua mensagem, mas pela maneira como essa mensagem é proferida e devidamente apropriada pela sociedade. E, como define Barthes (2009), "é a História que transforma o real em discurso". 
O mito se reporta a um processo contextualizado historicamente a partir de uma representação social formada mediante uma matéria já trabalhada, a fim de garantir a comunicação apropriada de uma determinada ideologia. Para Ortiz (2006, p. 38), o conceito de mito ainda sugere um ponto de origem a partir do qual se irradia uma história e um discurso mítico: "Sabemos em Antropologia que os mitos tendem a se apresentar como eternos, imutáveis, o que de uma certa forma se adequa ao tipo de sociedade em que são produzidos". Portanto, a ideia de uma democracia racial se configurar como mito diz respeito ao fato dessa visão estar consolidada no imaginário coletivo social do Brasil, transformada em ideologia oficial das relações raciais no contexto nacional, cujo ideário possui determinadas raízes históricas que remontam ao século XIX, como afirma Domingues (2005). Essa ideologia está intrinsecamente enraizada na produção intelectual de uma elite acadêmica e política interessada em transferir para os negros o peso por sua condição desprivilegiada na sociedade, o que incentivou e exaltou o processo de mestiçagem tanto como forma de "branqueamento" da população, como também celebrado como um sinal da inexistência de barreiras raciais. Mas Domingues (2005) também não exclui a responsabilidade do movimento abolicionista institucionalizado - representado pela figura de Joaquim Nabuco e da imprensa negra do começo do século -, que endossou essa ideologia, frequentemente comparando o sistema racial brasileiro ao norte-americano, representado pelo código oficial segregacionista sulista das Leis de Jim Crow, ${ }^{6} \mathrm{e}$ ao sul-africano (o apartheid), ${ }^{7}$ reconhecendo o Brasil como um modelo mais brando e até mesmo um paraíso multirracial: "Ao negar o preconceito racial, contribuía-se para desarticular a luta política antirracista, pois não se combate o que não existe”. (DOMINGUES, 2005, p. 8) O contexto da democracia

6 As Leis de Jim Crow se referem a uma legislação estadual decretada nos estados sulistas e limítrofes dos EUA que vigorou entre 1876 e 1965, cujas premissas mais contundentes exigiam que as escolas públicas e a maioria dos locais públicos (incluindo transportes) tivessem instalações separadas para brancos e negros. Esse conjunto de leis também afetava asiáticos e outros grupos minoritários.

7 A política oficial do apartheid (que significava "separação") foi adotada entre 1948 a 1994 na África do Sul, baseada no cerceamento dos direitos da maioria dos habitantes negros e instituída por governos sucessivos formados por uma minoria branca, que estabeleceram um regime de segregação racial. 
racial, de acordo com Fry (1996, p. 127), possibilitava uma hierarquização dos corpos de acordo com sua gradação de cor e não seria menos "real" que a discriminação "racial”, baseada na hierarquização de corpos de acordo com a raça.

Também o próprio movimento comunista brasileiro auxiliou na consolidação desse mito, pois, para esse grupo, o racismo era produzido pela diferença de classes, em que a injustiça racial era entendida como resultado das diferenças de ordem econômica e social. Mas o mito é ambíguo, pois existem dificuldades concretas e condições materiais racistas que impedem a sua total realização e, assim, a sua existência é puramente simbólica, pois se realiza no âmbito da linguagem. Mas, ao ser reelaborada e acionada social e coletivamente de forma sucessiva ao longo do tempo nas relações do cotidiano ou em discursos oficiais e midiáticos, a ideologia da democracia racial apresenta barreiras concretas para o desenvolvimento de ações políticas negras em um contexto social marcado pelo discurso da brasilidade mestiça. Por isso, para Ortiz (2006, p. 44), já que os próprios negros também se definem como brasileiros, o mito das três raças se torna exemplar e problemático, pois ele não apenas encobre tensões raciais como faz com que todos se reconheçam como nacionais.

Se Silva (1980) considerava importantes as reuniões públicas em bailes e eventos festivos de grupos negros como atos mobilizadores e conscientizadores, ele descartava o potencial político presente no consumo, entendido como mera tentativa de ingresso na sociedade capitalista, mesmo que fundamentasse uma identidade contraditória “como cidadãos". De certa forma, Silva (1980, p. 20) adiantava uma reflexão mais contemporânea em relação ao consumo como uma possibilidade de aquisição de uma cidadania alternativa e da construção de novos exercícios identitários "negros". Essa não parece ser a mesma visão de Lauro Cavalcanti, antropólogo, no artigo "Black-Breque: Estudo de um grupo ‘soul' em relação a adeptos do samba” (1981), também apresentado no encontro anual (Anpocs) realizado ano seguinte, no mesmo GT em que Carlos Silva apresentou seu artigo.

Hoje, vemos que esse texto representa um avanço nas reflexões sobre o movimento black brasileiro, e Cavalcanti (1981) enfocou especificamente o contexto carioca para promover um debate e uma comparação com o samba da época. A reflexão sobre esses embates e tensões foi utilizada para 
compreender a maneira pela qual esses dois gêneros - o samba e o soul - processariam identidades e etnicidades distintas a partir da confrontação de discursos de informantes oriundos desses dois universos. Cavalcanti (1981) tenta localizar o fenômeno do Black Soul dentro de um contexto mais amplo de emergência de movimentos de minorias étnicas em todo mundo, desencadeados especificamente no pós-guerra. Esse cenário chamou a atenção para a importância da etnicidade como fator preponderante de demarcação de diferenças e de novos significados a partir da configuração de categorias sociais distintas para além da classe. $\mathrm{O}$ autor apontou como exemplo significativo dessa nova compreensão do mundo moderno o crescimento do debate a respeito da questão racial, elencando algumas questões principais que mobilizavam o ainda insurgente movimento negro brasileiro:

A década de 70 no Brasil presenciou o debate da situação de negro em nossa sociedade de maneira tão intensa como jamais ocorrera anteriormente. Inúmeros grupos de intelectuais negros se reuniram e começaram a discutir sua identidade étnica, estudar seu passado e reivindicar seus direitos no presente. Houve a preocupação de auto-definição do grupo como afro-brasileiro, categoria que não estava tão impregnada pelo estigma do preconceito como crioulo, preto e negro; foi difundido, também, um questionamento da 'estética da brancura', que elegia os traços físicos tipicamente arianos como os mais belos, passando-se a tirar partido de características especificamente negras, como o cabelo encarapinhado, anteriormente rejeitado e disfarçado pelo alisamento. (CAVALCANTI, 1981, p. 2)

Cavalcanti aproveitou ainda para enumerar algumas críticas feitas aos participantes dos bailes black - que serão abordadas com mais profundidade no capítulo "O movimento" -, que consistiam em, por um lado, considerar o soul como resultado de uma importação de uma tendência cultural americana que não se encaixaria na realidade brasileira, especialmente segundo a visão de adeptos da democracia racial; enquanto outra visão criticava o movimento por uma suposta alienação, considerando o problema das classes sociais superior à questão racial. Iniciativas de mobilização político-racial, em geral, enfrentavam reações teóricas no Brasil, principalmente seguindo duas 
tendências. Uma mobilizava-se em defesa da democracia racial brasileira, que enaltecia a miscigenação e negava o racismo, em um país tido como "paraíso racial”, considerando qualquer movimento negro artificial e alienígena à realidade nacional. Para esse pensamento, tendências mais radicais de mobilização negra poderiam levar a conflitos. Uma segunda vertente de pensamento admitia, efetivamente, a existência do preconceito, mas atribuído à questão das classes sociais, pouco enfatizando a questão especificamente racial:

supõe essa linha de pensamento que o negro cessará de ser discriminado quando for resolvida a situação de disparidade das classes sociais, não vendo necessidade, portanto, de atribuir maior importância a um movimento negro que enfatize a questão étnica. (CAVALCANTI, 1981, p. 3)

Cavalcanti (1981, p. 3), nesse caso, busca uma terceira posição, ao tentar atribuir um significado maior ao soul, que, segundo ele, se constituiria, na época, talvez como "o único evento especificamente negro que mobilize grande número de pessoas”. Isso justificaria, para o autor, a sua comparação ao samba e a sambistas negros enquanto "exemplo máximo de negritude e brasilidade”, com discursos identitários e visões comuns entre os dois segmentos, mesmo que houvesse cisões e disputas.

Também é de 1981 o livro Carnaval Ijexá, de Antônio Risério. A obra, que teve apenas uma edição, é um testemunho situado entre o acadêmico, a crônica e a poesia sobre o desenrolar das novas ações e produções culturais afro-baianas durante os anos 1970, superpostas àquilo que o autor chama de "reafricanização", ${ }^{8}$ processo catalisador da influência negra norte-americana na configuração de um contexto "afro-ijexá", que incorporava convergentemente questões culturais derivadas dos processos de libertação das antigas colônias portuguesas na África e traços da tradição afro-brasileira. Essa reafricanização seria marcada pelo uso, no cotidiano ou no contexto da festa, de símbolos ligados a uma determinada africanidade que demarcavam uma

8 Uma definição espontânea de reafricanização, para Risério (1981, p. 13): “Os pretos se tornam mais pretos, digamos assim; se interessam cada vez mais pelas coisas da África e da negritude. Mas vivem, intensa e essencialmente, o presente, jogando aberto para o futuro". 
interação tanto com uma ancestralidade e uma mitologia quanto com uma cultura globalizada, em fluxos desiguais e desterritorializados de símbolos mundiais diaspóricos. Discutindo diversos temas, Risério analisa as dinâmicas internas da vida da juventude afro-mestiça baiana, especialmente no tocante às atividades de entidades carnavalescas recém-criadas, como os blocos afro e afoxés, bem como as relações dessas agremiações com o movimento negro na Bahia e, por conseguinte, no Brasil, realçando a importância da politização do carnaval, do corpo e da música.

Para Risério (1981, p. 18), esses processos coexistentes e paralelos da reafricanização estariam se desenvolvendo no interior de um "boom da negritude" e teriam sua direta expressão tanto nas performatizações públicas de uma cultura até então restrita a "guetos" e espaços periféricos, como na própria expansão física, social e cultural da periferia até locais públicos da cidade. Como exemplo, o autor reproduz a frase do ator baiano Mário Gusmão (1928-1996), primeiro negro formado na Faculdade de Teatro da Universidade Federal da Bahia (UFBA): "O Ilê foi, simplesmente, o bloco que teve a coragem de botar no meio da rua aquilo que antes só acontecia na cozinha”. (RISÉRIO, 1981, p. 18) No mesmo trecho, Gilberto Gil, em entrevista ao autor, considera o momento como aquele em que "os negros começam a conquistar a possibilidade de se autogerir esteticamente”. (RISÉRIO, 1981, p. 18) Assim, o autor aponta para as potencialidades de uma maior autonomia por meio da estética, empreendidas por um determinado grupo de jovens afro-mestiços baianos, que utilizavam a festa, a música, a dança, o corpo e a performance como substratos para uma possibilidade concreta de transformação social.

9 Ao longo do livro, Risério utiliza diversas vezes o termo "gueto" para se referir aos bairros periféricos pobres e negros de Salvador, utilizando o termo de acordo com o senso comum. No entanto, diante da observação da sociedade brasileira ao longo de sua história, a associação de gueto à experiência racial brasileira aparece um tanto deslocada, pois, de acordo com Wacquant (2004), o conceito de gueto se refere a uma historiografia ligada à diáspora judaica pela Europa e se relaciona ainda à experiência negra nas grandes cidades norte-americanas. A "guetização", que tinha um propósito definido de cercamento e controle étnico-racial, era um dispositivo sócio-organizador segregador do espaço urbano pautado por uma violência coletiva, com propósitos de ostracismo social. Wacquant considera as áreas pobres brasileiras como exemplos de aglomerações étnicas, marcadas pela pobreza e segregação, mas guardando suas especificidades. 
Algumas passagens do livro de Risério foram retomadas por Vianna em 1988, na publicação mais famosa e pioneira sobre o funk no Rio de Janeiro, O mundo funk carioca. O livro de Vianna representou um marco para os estudos acadêmicos sobre o funk e foi derivado de sua dissertação de mestrado em Antropologia (1987). Nele, Vianna descortinou uma cena musical e um universo que até então eram ignorados pela grande mídia e pela classe média brasileira. Ao tentar traçar uma genealogia do funk carioca, originado tanto do funk norte-americano das décadas de 1960 e 1970 quanto das batidas eletrônicas do freestyle e do Miami bass, ${ }^{10}$ Vianna abordou a história da Black Rio e de sua metamorfose no movimento do charme nos anos 1980, analisando a ligação concreta entre o universo cultural do funk e a vida nas favelas do Rio de Janeiro em seu cotidiano de exclusão social. Mas deixa de lado a problemática racial, o que pode estar relacionado a uma dificuldade de identificar esses fatores na produção de desigualdade e identidade, como critica Pinho (2005, p. 134).

Outro trabalho seminal sobre o universo do funk e também do rap no Rio de Janeiro foi o livro de Micael Herschmann, O funk e o hip hop invadem a cena (2000). O foco do trabalho de Herschmann (2000, p. 19) recai sobre o debate sociocultural e sobre as transformações na cidade, enfocando as narrativas sobre violência e cultura urbana que giravam em torno das figuras de funkeiros e rappers, a fim de refletir sobre o lugar do pobre no debate político e intelectual brasileiro. Para isso, Herschmann recorreu aos primórdios do movimento soul, mapeando as condições de emergência do funk e do hip hop no Rio de Janeiro e abordando as diferentes estratégias que esses jovens utilizavam para se inserir na cena cultural pública. $\mathrm{O}$ autor parte da música e dos bailes para compreender a criação de novos patamares e modelos de cidadania, próximos da comunicação de massa e do consumo (HERSCHMANN,

10 Freestyle é um gênero musical originado na virada dos anos 1970 para os 1980, diante da decadência da disco music, basicamente desenvolvido em comunidades latinas e negras de Nova York e Miami. Utilizando batidas eletrônicas de teclados e sintetizadores e misturando elementos rítmicos e melódicos do R\&B, dance e house music, era uma música dançante, mas melódica, com temática romântica, que, por sua vez, deu origem ao Miami bass, mais dançante e sincopado, com batida mais grave e intensa, fundamentado sobre a atuação criativa de DJs, substituindo temas românticos pela fala das ruas em gravações com temáticas sexuais, que baseou a constituição do funk carioca. 
2000, p. 38-39), analisando como essas práticas culturais, representações e estilos de vida refletiam a realidade e as dinâmicas sociais.

Alguns estudos acadêmicos sobre a história do movimento negro no Brasil foram produzidos tanto por pesquisadores brasileiros quanto estrangeiros, e dentre eles, destaca-se o livro de Michael Hanchard, Orfeu e o poder, o movimento negro no Rio de Janeiro e São Paulo (1945-1988), publicado no Brasil em 2001, traduzido do original em inglês lançado em 1994. Resultado de sua tese de doutorado em Ciência Política da Universidade de Princeton, em Nova Jersey, Hanchard se propôs a compreender a constituição do movimento negro no Brasil, partindo das cidades de São Paulo e Rio de Janeiro. Para o autor, as organizações políticas afro-brasileiras não possuíram um percurso sistemático e constante em comparação ao contexto norte-americano (HANCHARD, 2001, p. 19), a despeito do fato de que a população brasileira seria, oficialmente, composta por $54,9 \%$ de negros ${ }^{11}$ - enquanto, nos EUA, a população afro-americana corresponde a quase $13 \%$ do total. Baseando-se na teoria da hegemonia de Gramsci, Hanchard tentou compreender diversos mecanismos de exclusão instituídos pelas elites brasileiras que garantiram um regime de hegemonia racial e foram utilizados como instrumento de manutenção do poder, subalternizando os negros. Partindo desse pressuposto, o autor localizou as diferentes etapas do estabelecimento do movimento negro nacional como integrante das lutas pelas liberdades democráticas, especialmente entre as décadas de 1970 e 1980. Especialmente nos trechos em que tratou do Black Soul como uma célula embrionária para a constituição de uma política racial é que Hanchard apontou criticamente para uma suposta inoperância das práticas culturais enfatizadas pelos movimentos negros brasileiros.

Embora os promotores e disc-jóqueis do Black Soul talvez simpatizassem com as atividades políticas clandestinas durante esse período, eles mesmos não eram agentes dessas atividades [...]. Apesar de suas repercussões simbólicas, as festas eram um fim em si. Daí

11 Segundo Pesquisa Nacional por Amostra de Domicílios Contínua (PNAD-C) de 2016, realizada pelo Instituto Brasileiro de Geografia e Estatística (IBGE). 
a separação entre as práticas políticas e culturais do Black Soul e de outros grupos afro-brasileiros mais explicitamente políticos da época. (HANCHARD, 2001, p. 141)

Ao desconsiderar a potência da cultura como prática de intervenção política - englobando também o candomblé e outras religiões afro-derivadas, músicos, dançarinos e outros artistas populares -, Hanchard (2001, p. 39) criticou o que chamou de estratégia "culturalista" dos movimentos negros brasileiros. Para o autor, a cultura teria sido usada como um fim em si mesma, e não como uma forma de mobilização e ação política para a luta pelos direitos civis dos negros no país. Especialmente em relação aos bailes de soul, Hanchard (2001, p. 142) considerou que movimento serviu apenas como repositório de identificação intersubjetiva e "incompleta" em sua "[...] valorização de formas de expressão pessoal e de identificação que, antes dele, eram reprimidas ou negadas pelos brancos e não brancos do Brasil”. Hanchard ainda responsabilizou as políticas de identidade desenvolvidas pelos movimentos negros brasileiros pela ausência ou esvaziamento de um projeto concreto político de enfrentamento do racismo, ${ }^{12}$ o que não se comprova, pois, em realidade, apesar de receber críticas de alguns intelectuais negros, o Black Soul trouxe para o debate público a discussão sobre a questão racial, apontando para novas formas de afirmação identitária e ação política, como discutirei nos próximos capítulos.

Outro americano, o brasilianista Bryan McCann, também produziu um interessante trabalho em 2002, "Black pau: uncovering the history of brazilian soul”. No extenso artigo, McCann se dedicou a criar uma genealogia do soul no Brasil, tanto como movimento cultural quanto em relação à própria configuração do gênero musical no mercado fonográfico brasileiro da época. Tendo a produção musical massiva como mote principal do artigo,

12 Sobre esse aspecto, a tese de Hanchard (2001) recebeu um ensaio crítico de Pierre Bourdieu e Louis Waquant, no qual acusam o autor de ser incapaz de compreender a dimensão global das experiências raciais no contexto da diáspora africana por conta de uma visão etnocêntrica e "imperialista”, que usaria como único modelo de combate ao racismo aquele praticado nos EUA, desenvolvido a partir do movimento pelos direitos civis dos afro-americanos. Para mais, ver: Bourdieu e Wacquant (1999). 
McCann não se ateve a questões como a criação de um movimento negro ou discussões a respeito de reconfigurações identitárias. Para o autor, existiu uma relação direta de causa e efeito, ou de entrelaçamento e sobreposição, entre uma produção musical local e as movimentações em torno dos bailes de subúrbio, sugerindo como momento-chave para a configuração de uma cena de black music brasileira as trajetórias midiáticas de artistas como Tim Maia, Jorge Ben Jor e Dom Salvador, dentre outros, responsáveis pela criação do soul brasileiro como um subgênero musical. (MCCANN, 2002, p. 35-34) De fato, McCann (2002, p. 40) postulou que o primeiro álbum de Tim Maia (Tim Maia, 1970, Polydor) "inaugurou o Soul Brasileiro como um subgênero vocal musical”, afirmando que o cantor foi uma espécie de retransmissor da cultura negra norte-americana - destacando o cantor inclusive como pioneiro no uso do cabelo afro no Brasil -, difundindo-a por entre seus fãs, em sua maioria concentrados nos subúrbios cariocas. Mas o autor retira de Tim Maia a responsabilidade por ter sido um porta-voz de um emergente movimento black em termos políticos, visto que o cantor dava frequentes declarações à imprensa ressaltando sua origem "mulata" ou mestiça, e não negra. (MCCANN, 2002, p. 43)

É na segunda parte do artigo que McCann se detém com mais ênfase na Black Rio, desmembrando alguns processos em relação às atividades das equipes de som, chamando a atenção para a discussão que motivou grande parte das análises a respeito dessa cena musical.

O Soul era, portanto, um fenômeno social nascido com uma luta em seu coração sobre o seu próprio significado: Seria um veículo para a consciência política negra, ou simplesmente mais um modismo pop enriquecendo promotores experientes?. (MCCANN, 2002, p. 49)

Aqui, a ideia de pop, segundo Soares (2014), se articula a modos de produção e consumo orientados pelas lógicas do mercado, compondo um conjunto transacional de imagens, sons e ícones, norteados para o entretenimento e conectados a estilos de vida e consumo juvenis. Furtando-se de oferecer uma resposta definitiva, McCann (2002) creditou as implicações políticas do movimento ao seu caráter transgressor, o que superaria fronteiras sociais a 
partir da celebração de novas formas de cultura popular diante de um aumento do poder de compra de uma classe trabalhadora negra e mestiça.

Apesar de estarem fora da academia, Assef (2003) e Essinger (2005) foram dois jornalistas que acompanharam um processo de revalorização da black music no Brasil no começo dos anos 2000, publicando reflexões importantes do ponto de vista histórico sobre essa produção musical massiva nacional. Assef, em Todo DJjá sambou (2003), se propôs a traçar uma genealogia da atividade dos DJs brasileiros de diversos gêneros musicais, abordando também a cultura da noite, a cena clubber e a produção musical dançante desde os anos 1950 até a atualidade. A jornalista deu especial destaque a determinados personagens ligados à criação do samba-rock enquanto cena musical e gênero musical paulistano. Um deles foi Osvaldo Pereira que, segundo Assef, foi o primeiro DJ de que se tem conhecimento no Brasil. Durante a juventude, o DJ Osvaldo criou a sua “Orquestra Invisível Let's Dance”, que nada mais era do que um conjunto de equipamentos de som escondido atrás de uma cortina, que animava bailes populares reproduzindo a atmosfera sonora das grandes orquestras que se apresentavam ao vivo nas festas da elite local. Osvaldo acabou por inspirar toda uma geração de DJs de black music, tanto em São Paulo - plantando a semente do movimento hip hop - quanto no Rio de Janeiro. O livro ainda teve dois capítulos dedicados aos bailes do Rio de Janeiro, desde o movimento black, passando pelo charme e funk, abordando também a evolução das discotecas que acabaram por popularizar uma sonoridade pop-eletrônica no país.

Já Sílvio Essinger, em Batidão: uma história do funk (2005), realizou uma intensa e detalhada pesquisa histórica em um livro-reportagem que representou um passo adiante em relação ao trabalho de Vianna a respeito do universo do funk carioca. O ponto de vista de Essinger é voltado para o momento da chegada do funk à grande mídia nos anos 1990, ultrapassando os limites das favelas e atingindo um público mais amplo, consolidando um mercado e estabelecendo também novos parâmetros para a produção musical popular periférica. Figuras mais contemporâneas do funk, como Mr. Catra, Bonde do Tigrão e Tati Quebra-Barraco, possuem destaque especial no livro do jornalista, oferecendo uma visão alternativa sobre a cultura das favelas cariocas. No livro, o autor concedeu especial atenção ao movimento 
Black Rio, produzindo extenso material a partir de depoimentos de personagens centrais para a cena, como disc-jóqueis e produtores que atuaram na época, chamando atenção para o desenvolvimento de uma cena musical marginal e alternativa, que manteve instáveis e inconstantes relações de aproximação e distanciamento com a grande mídia e com a indústria fonográfica mainstream.

Abordando especialmente a história de um clube social suburbano carioca que foi palco de diferentes projetos que estabeleceram novos parâmetros para exercícios da negritude carioca, Sônia Giacomini, no livro A alma da festa: família, etnicidade e projetos num clube social da Zona Norte do Rio de Janeiro - o Renascença Clube (2006), construiu uma reflexão sobre discursos e valores articulados a uma comunidade de negros ligados a uma agremiação na qual vivenciavam uma experiência de classe média ainda na década de 1950. Como espaço de desenvolvimento dessa "elite negra”, o Renascença Clube representava um território intermediário entre uma burguesia tradicional branca e grupos proletários negros mais pobres. Seus sócios e fundadores possuíam aspirações relacionadas a uma ascensão social, econômica e educacional.

O Renascença deixou sua marca na história cultural do Rio de Janeiro especialmente por conta das rodas de samba e dos concursos de misses negras, mas também foi palco de um dos bailes mais emblemáticos do movimento Black Rio. Alguns de seus sócios, organizadores e frequentadores se tornaram bem-sucedidos produtores culturais da cena black carioca ao longo dos anos 1970 e figuras de destaque no meio cultural e político negro carioca, como será discutido a seguir. Os bailes de soul do Renascença demarcaram também um contexto importante para o clube, pois estabeleciam relações concretas entre essa "elite de cor" e grupos de negros mais pobres, representando também o encontro de gerações e oferecendo um espaço favorável para o contato com uma cultura transnacional diaspóricas, em lugar de uma brasilidade. (GIACOMINI, 2006, p. 216)

É interessante que justamente de uma área a princípio distante dos estudos sobre música e identidade, veio a tese de Rita Aparecida Ribeiro, Identidade e resistência no urbano: o quarteirão do soul em Belo Horizonte (2008). O trabalho apresentado ao Programa de Pós-Graduação do Departamento de Geografia da Universidade Federal de Minas Gerais (UFMG) é um estudo 
amplo que envolve temas como organização do espaço, sociabilidades, produção midiática e apropriações simbólicas. O pensamento geográfico, nesse caso, serviu como aporte para a compreensão de processos de identificação, representação e ocupação de espaços desenvolvidos a partir do Quarteirão do Soul, em Belo Horizonte, ocupação cultural onde fãs de black music se reúnem em uma rua da cidade para se encontrar, dançar, ouvir música e celebrar memórias. No trabalho, a autora realizou diversas entrevistas com personagens-chave do movimento soul carioca, que influenciou o desenvolvimento de uma cena black em Minas Gerais. Mas a autora acaba por se apoiar excessivamente sobre ideias como "resistência”, "luta”, "dominação", deixando de lado ambiguidades, tensões e conflitos inerentes a qualquer manifestação cultural, acabando por oferecer uma visão homogeneizante, sem observar faces mais complexas do objeto em questão.

Carlos Palombini (2009) e José Roberto Zan (2005) contribuíram para o debate produzindo dois artigos importantes para a compreensão da configuração do gênero do soul no mercado musical brasileiro, apresentando o movimento black como um braço fundamental desse processo. Palombini (2009, p. 42), no extenso artigo "Soul brasileiro e funk carioca", realiza uma revisão bibliográfica profunda que contribui para a genealogia dos dois gêneros musicais enquanto momentos de "apropriação e ressignificação de músicas africano-norte-americanas por industriais e artistas brasileiros” que integraram um processo maior, relativo à própria constituição da fonografia no Brasil. Já em "Jazz, soul e funk na terra do samba: a sonoridade da banda Black Rio", Zan (2005) se atém basicamente a uma análise estrutural dos discos e da trajetória do grupo musical, que promoveu uma hibridação de gêneros musicais nacionais e estrangeiros, o que acabou por gerar, segundo o autor, uma ressignificação do samba em consonância com novos movimentos identitários "transterritoriais" e diferentes tendências musicais. Mas a relação entre os bailes de soul e a indústria fonográfica foi eclipsada no texto, pois o autor, ao replicar um trecho do livro de Vianna (1988, p. 110) referente especificamente ao contexto do funk, reitera a visão de que a Black Rio não estaria atrelada às prioridades da indústria fonográfica multinacional. Mais à frente, perceberemos que essa hipótese não se confirma, visto que as gravadoras investiram pesadamente no segmento do soul, o que gerou altos lucros, mesmo por um curto período. 
Nesse sentido, tanto Palombini quanto Zan relegaram à cena musical dos bailes black um papel secundário ou consequencial em relação a uma reorganização mais ampla da indústria fonográfica. Para os autores, a Black Rio teria sido uma reação a um estímulo do mercado, deixando de lado sua importância política, visão razoavelmente coerente com McCann (2002), mas diametralmente oposta à proposta de Ribeiro (2008), que, por sua vez, creditou às gravadoras uma ação coadjuvante, simples resposta às demandas de uma juventude negra. A autora acaba por enfocar apenas processos subjetivos de identificação sem atentar para a importância do consumo cultural como central na criação de novos segmentos de mercado e também de novas formas de cidadania e políticas culturais. (GARCÍA CANCLINI, 1997, 2008)

Outro ponto discutível é em relação à compreensão de que o Black Soul corresponderia a um momento da história cultural do negro brasileiro em que "[...] se formava um movimento social, até certo ponto itinerante [...], mas fortemente coeso a partir a criação de uma identidade coletiva”, como novamente aponta Ribeiro (2008, p. 121). O que logo se mostra contraditório, visto que, desde o seu princípio, havia tensões e diferentes propósitos, além de conexões e estreitas relações entre essa cena alternativa e o mainstream cultural carioca. Seja no trânsito de DJs entre bailes da Zona Norte e boates da Zona Sul, seja no flerte inicial, e depois confirmado, com gravadoras multinacionais na produção e circulação de discos e com a grande imprensa - mesmo que esta olhasse o movimento com desconfiança -, que correspondiam às instâncias da cultura mainstream da cidade.

Pesquisas mais recentes nas áreas de música, ciências humanas e sociais têm se voltado para a história dos bailes soul em dissertações de mestrado e teses de doutoramento. Esses trabalhos, de certa forma, possuem em comum a reflexão e a valorização, mesmo que percebendo algumas tensões, de uma nova produção cultural negra independente, lançando olhares mais complexos sobre o objeto. A dissertação de Eloá Gonçalves (2011), do mestrado em Música da Unicamp, se voltou especificamente para a trajetória da banda Black Rio, com foco na musicalidade e na análise do repertório, abordando o surgimento do grupo como consequência da movimentação em torno dos bailes e uma reação da indústria fonográfica da época, que desejava explorar esse novo segmento de mercado. A cena black de São Paulo foi o objeto da 
dissertação de Daniela Silva (2013), da área de Estudos Culturais, que buscou compreender a influência da música negra norte-americana na juventude negra de São Paulo, avaliando também seus efeitos em movimentos mais contemporâneos, como o hip hop. Os bailes black paulistanos também foram estudados por Félix (2000), que realizou uma etnografia em festas promovidas duas equipes locais a partir de um viés antropológico, refletindo superficialmente sobre a trajetória histórica dessas manifestações. Esses dois trabalhos mencionam brevemente a importância da cena musical da Black Rio para o contexto de São Paulo, compreendendo separadamente esses dois cenários e observando algumas especificidades locais.

Do campo da música, também veio o trabalho de Sabrina Lôbo Moraes (2014), que realizou uma aprofundada pesquisa histórica sobre a Black Rio e sobre o universo do samba dos anos 1970 a partir de material da imprensa da época. Moraes discute as tensões e conflitos criados no embate entre os adeptos do soul e do samba, não apenas como um reflexo de estratégias de marketing da indústria fonográfica, mas como representação das disputas simbólicas e dos julgamentos de valor entre uma produção cultural nacional e uma internacionalizada. Em 2015, foram produzidos dois trabalhos importantes como a tese de doutorado de Carlos Eduardo Paiva, sobre a soul music no Brasil e as reconfigurações na identidade negra. A pesquisa em ciências sociais destina um capítulo à Black Rio, mas discute o contexto geral da emergência do gênero do soul no país, abordando também a carreira de cantores identificados com a black music americana, como Tim Maia e Jorge Ben Jor, e os diálogos entre o soul e a Música Popular Brasileira (MPB) da época. A segunda pesquisa é a dissertação de André Garcia Braga (2015), do Programa de Pós-Graduação em Antropologia Social da Universidade Federal do Rio Grande do Norte (UFRN), A cena Black Rio: circulação de discos e identidade negra. Apesar do autor não trabalhar com o conceito de cena musical diretamente, ele aborda os processos comunicativos desencadeados a partir da circulação de discos de vinil, que serviram como instrumento para a interpretação da formação e do desenvolvimento da Black Rio, observando o consumo desses artefatos inseridos no contexto do Atlântico Negro. (GILROY, 2001) 
Ao lado de McCann, desde os EUA, Paulina Alberto, professora brasileira de história da Universidade de Michigan, propõe uma interpretação do movimento Black Rio bastante complexa e abrangente. A partir da pesquisa que deu origem ao livro Terms of inclusion: black intellectuals in twentieth-century Brazil (2011), editado pela Universidade da Carolina do Norte, nos EUA, a autora publicou o artigo "When Rio was black: soul music, national culture, and the politics of racial comparison in 1970s Brazil", que discute como os bailes soul fizeram parte de uma importante etapa da constituição do movimento negro no Brasil, especialmente no Rio de Janeiro. Apoiada em uma extensa pesquisa em jornais da época, tanto os de grande veiculação quanto publicações independentes relacionadas a grupos de militantes negros, a autora ainda usa como recurso para basear suas conclusões arquivos de investigação da polícia secreta da ditadura, oferecendo uma visão bastante ampla sobre como a sociedade da época encarava o soul, seus participantes, suas modas e as políticas raciais decorrentes do fenômeno. A interpretação desses debates públicos, por si só, representa um rico material que permite uma percepção mais acurada de como participantes da cena black e a sociedade em geral tentavam definir raça e cultura nacional em um contexto de intensos debates políticos e posicionamentos radicais, discussão que irei aprofundar nas próximas seções.

Em meados dos anos 1970, o Brasil testemunhava uma lenta abertura, que relaxou a censura e as tentativas de controle sobre reuniões e ajuntamentos públicos, favorecendo o aparecimento de uma maior diversidade de expressões culturais públicas. Sob a pressão de setores moderados da sociedade civil, o regime militar dava início a um período de distensão lenta e gradual durante o governo Geisel (1974-1979). (FERREIRA; GRYNSZPAN, 2000, p. 133-134) Esse foi um momento-chave na trajetória da política brasileira, caracterizado especialmente pela realização de eleições para escolha indireta de governadores, vereadores, deputados e um terço do Senado, garantindo certa dose de liberdade desde a edição do Ato Institucional 5 (AI-5) em 1968. Tanto Dunn (2009) quanto Cavalcanti (1981) consideram o Black Soul como um braço da contracultura brasileira, no sentido de criação de uma produção cultural alternativa, divergente, instigante e fundamentalmente jovem, que se 
interessava menos pelo protesto político convencional e mais pela articulação de novas identidades pessoais e coletivas.

Heloísa Buarque de Hollanda (1992) observa que a contracultura urbana do início da década de 1970 tendia a se identificar menos com o povo ou com o proletariado revolucionário e mais com minorias raciais e sexuais. Isso propiciou, no Brasil, "um encontro direto, face a face, entre setores jovens marginalizados e setores jovens economicamente privilegiados, nas grandes cidades brasileiras”. (RISÉRIO, 1981, p. 23) Nesse sentido, o movimento Black Soul não se enquadraria como um braço da contracultura brasileira, mas com ela dialogava, ajudando a trazer para a esfera pública o debate sobre o lugar social da diferença, sem se opor ao mundo social e, principalmente, ao mercado, formando diversas alianças estratégicas que refletiam a transição de um paradigma político-cultural para uma perspectiva mais individualista.

A ênfase no indivíduo que caracterizava a cena black também convergia com a proposta da Segunda Onda do feminismo, que propagava o lema de que "o pessoal é político", conjugando a luta contra diferentes opressões com discussões relativas à cultura do cotidiano e à intimidade da vida privada. Mas o Black Soul divergia fundamentalmente da postura contracultural, que implicava uma noção de indivíduo da qual estaria excluído, ou ao menos sublimado, o seu caráter de sujeito social. (CUNHA, 2009) Ou seja, para os contraculturais, o indivíduo definia-se mais pela sua subjetividade, voltando-se para seu mundo interior em oposição ao mundo social - que englobaria a sociedade burguesa e capitalista, o status quo, o mundo do trabalho, o dinheiro, as religiões institucionalizadas, as estruturas tradicionais da sociedade. E, como notaremos a seguir, tanto os frequentadores quanto os organizadores, artistas e DJs da cena black demandavam por inserção social e ansiavam por exercitar seu poder de compra, utilizando, inclusive, recursos inseridos no capitalismo global, fazendo do consumo uma fórmula de acesso à cidadania $\mathrm{e}$ à igualdade social.

Ao analisar mais profundamente a atuação das equipes de som mais importantes do período nas próximas seções, pode-se perceber que, de forma alguma, existiam mesmas preocupações e agendas políticas na pauta dos bailes por elas organizados. Da mesma forma, esse fenômeno não decorre necessariamente de um estímulo das grandes gravadoras, interessadas em 
novos segmentos consumidores. Não havia, de forma alguma, coesão, e visões que corroboram perspectivas homogeneizantes dos processos culturais deixam de lado a noção de que a cultura é palco de conflitos e tensões em processos dinâmicos de legitimação e transformação. Os significados dos produtos culturais estão sempre em disputa, retrabalhando múltiplas identidades, cada vez mais articulados a questões mercadológicas, devendo, pois, ser repensados de formas mais sutis e complexas, evitando reduções.

\section{Hello, crazy people!}

$\mathrm{O}$ viaduto 31 de Março, construído no bairro do Catumbi, região suburbana próxima ao centro do Rio de Janeiro, esconde a história do Astória Futebol Clube, clube recreativo e esportivo construído aos pés do morro do Estácio na década de 1930. Quarenta anos depois, o Astória foi a arena da realização do primeiro baile efetivamente black de que se tem notícia no Brasil. Organizado pelo disc-jóquei Mr. Funky Santos (1950-2012), no dia 10 de novembro de 1971, o evento foi o primeiro no qual só se tocou e se dançou soul music. No entanto, Vianna (1988, p. 24-25), Essinger (2005, p. 17-18) e Thayer (2006, p. 90) consideram os Bailes da Pesada, promovidos pelos DJs Ademir Lemos e o jovem branco de classe média Newton Alvarenga Duarte, conhecido como Big Boy, na casa de shows Canecão, na Zona Sul do Rio de Janeiro, o evento fundador da Black Rio. ${ }^{13}$ De fato, o primeiro Baile da Pesada foi realizado em 12 de julho de 1970, pouco mais de um ano antes de Mr. Funky Santos realizar sua primeira festa. Como muitos outros jovens da época de todo o Rio de Janeiro, Mr. Funky, ou Oséas Moura dos Santos, foi influenciado por Big Boy, então um famoso DJ, locutor de rádio e apresentador de TV. Em seus famosos Bailes da Pesada, Ademir e Big Boy começaram a introduzir a soul music, apesar de que o rock progressivo e o pop ainda predominavam no set list da festa, de acordo com Assef (2003, p. 46). Mas o ponto alto era quando o DJ tocava algum sucesso de James Brown, lotando a pista.

13 Sobre a origem dos bailes, Dom Filó (2009) também questiona essa narrativa: "Costumam atribuir a Big Boy e Ademir Lemos, no Canecão, o surgimento do soul no Brasil. Mas isso não é verdade! O fato é que nós tínhamos intervenções no subúrbio por conta de vários outros companheiros, que se reuniam pra fazer festas nas casas". 
Eu gostava de rock, gostava de blues, gostava até de reggae, mas o soul mesmo ele ainda não tinha me despertado. E a primeira vez que eu ouvi soul foi exatamente com Big Boy. Eu ouvi James Brown. Então a partir dali eu juntei uma galera e nós começamos a pesquisar músicas. ${ }^{14}$ (RIBEIRO, 2008, p. 108)

Big Boy já difundia o soul em seus programas de rádio antes dos discos do gênero chegarem ao Brasil e foi um grande divulgador do som de James Brown, dedicando alguns minutos de seu programa diário à black music. Mas a ideia de realizar um baile que tocasse soul partiu de outro discotecário famoso na época. Pecegueiro, publicitário e empresário de Big Boy, no documentário The Big Boy Show (2004), conta:

Quem começou tudo isso foi Ademir [Lemos]. O Newton me telefonou um dia e disse: 'precisamos conversar, o Ademir da Le Bateau teve a ideia de fazer um negócio, um baile em um esquema popular em um lugar gigantesco. Parece que ele já fez contato com o Canecão’.

De fato, segundo o próprio Ademir Lemos, em depoimento ao programa Brasil Legal exibido em maio de 1991, foi ele quem contratou Big Boy para animar o baile.

Newton Duarte de Alvarenga, antes de se tornar o Big Boy (1943-1977), morava no bairro do Flamengo, Zona Sul do Rio, e gastava toda a mesada com discos, inclusive comprando muitos em São Paulo. Era fã dos Beatles, mas, atento às novidades da música pop, começou a trabalhar como programador de sequências musicais na Rádio Tamoio, ainda em 1964. Formado em Geografia, chegou a trabalhar como professor enquanto iniciava, paralelamente, sua carreira de sucesso como locutor de rádio, apresentando, posteriormente, programas na televisão e escrevendo colunas de jornal. Foi para a Rádio Mundial (860) AM comandar um programa musical que foi sucesso entre os jovens, lançando bordões inovadores como "Hello, crazy people!" e conseguindo um feito até então difícil na mídia carioca: se comunicar com o

14 Depoimento de Mr. Funky Santos publicado na tese Identidade e resistência no urbano: o Quarteirão do Soul em Belo Horizonte, de Ribeiro (2008). 
público jovem, que crescia cada vez mais, chamando a atenção da indústria musical. A Mundial pertencia ao grupo Globo, que tinha um potente sistema de transmissão que permitia que o programa de Big Boy chegasse a São Paulo e a cidades do interior do Brasil. (ASSEF, 2003, p. 37) O aumento dos índices de audiência jovem proporcionado pela programação musical oferecida pelas emissoras de TV desde os anos 1960 também gerou mudanças na programação das rádios, que se voltavam cada vez mais para esse público. Big Boy criou um personagem divertido, anárquico e espontâneo, mais próximo dos jovens, veiculando os principais lançamentos do hit-parade norte-americano e europeu. ${ }^{15}$ Se não se pode necessariamente creditar a ele o pontapé pioneiro e original na origem da Black Rio, decerto Big Boy foi o responsável pela popularização do soul nas rádios brasileiras, pois há registros de que ele foi o primeiro a tocar soul em uma emissora de rádio popular, ainda em 1967, segundo Hanchard (2001, p. 135).

O sucesso no rádio levou Big Boy para as pistas de dança, criando inicialmente o Baile da Cueca, em São Paulo, que, com uma seleção de novos hits e suas apresentações, tornaram o empreendimento um sucesso. Lançou diversas coletâneas, com os sucessos do seu baile, e simultaneamente começou a apresentar os Bailes da Pesada ao lado de Ademir Lemos, no Rio, com características semelhantes. A casa escolhida foi o Canecão, misto de cervejaria e casa de shows localizada no bairro de Botafogo, Zona Sul do Rio, reconhecido como palco de shows de grandes nomes da MPB. Os bailes eram realizados aos domingos, e o set list era "uma mistura de novidades do rock e da soul music, organizados em blocos, que eram entremeados por suas sempre transloucadas intervenções ao microfone”. (ESSINGER, 2005, p. 17) O baile foi um sucesso, contando com um público frequente de 5 mil pessoas por noite, segundo Vianna (1987, p. 51). As telas dos alto-falantes das caixas acústicas do equipamento de som eram pintadas com figuras de cartas de baralho em tinta fluorescente, que, sob o efeito da luz negra, apresentavam um

15 Big Boy foi ainda pioneiro no começo das operações da FM no país e assinou a programação da Rádio Eldo Pop, do Sistema Globo de Rádio em 1973, uma rádio de vanguarda que só tocava rock, especialmente progressivo. 
belo visual. Enquanto Big Boy era o animador, Ademir era responsável pelos sets de soul music da festa.

Você estava dançando e daqui a pouco Big Boy tocava um Pink Floyd, [do disco] Ummagumma [...]. Aí você tinha que sentar, cruzar as pernas e ascender um baseado. Ficava aquele clima de paz-e-amor. Na hora em que tocava um soul, a negada do subúrbio abria uma roda. Mas eram quinze minutinhos de alegria só e ele cortava. ${ }^{16}$ (ESSINGER, 2005, p. 19)

Antes de começar a realizar os Bailes da Pesada, Ademir Lemos Inácio (1946-1998) já era um discotecário de grande influência nas boates da Zona Sul da cidade. Lemos, ${ }^{17}$ conhecido como "Homem Baile" começou sua carreira artística como dançarino de rock em 1966, no programa Os brotos comandam, da TV Continental. (ASSEF, 2003, p. 39) O programa era comandado pelo amigo Carlos Imperial, grande nome do entretenimento e da música jovem brasileira. Os dois haviam se conhecido quando Imperial convidou Ademir para trabalhar na curadoria das músicas do seu programa Clube dos brotos, na Rádio Nacional. Mas acabou se destacando mesmo no final dos anos 1960 como discotecário em boates como Jirau e Le Bateau, em Copacabana, onde ele não apenas tocava os vinis, como animava a festa dançando e recebendo os frequentadores. Da mesma forma que Big Boy, Ademir também lançava moda: "Ele era o próprio showman, com sua cabeleira black - um estilo que começava a ser adotado por alguns jovens da cidade [...]”. (ESSINGER, 2005, p. 18) Especializado em rock e pop, fez a transição para o soul a partir dos Bailes da Pesada, gênero que acabou por dar o tom das noites dançantes no Canecão e possuía um diferencial que o distinguia de outros disc-jóqueis da época: “[...] Ademir foi o primeiro DJ brasileiro a se preocupar

16 Depoimento do Mr. Funky Santos publicado no livro Batidão: uma história do funk, de Essinger (2005).

17 Para Palombini (2009, p. 52), Ademir Lemos era mestiço, enquanto, segundo McCann (2002), ele era branco, o que pode denotar tensões nas apreensões e percepções sobre cor e raça entre observadores brasileiros (no caso, Palombini) e americanos (McCann), de acordo com as experiências culturais e raciais específicas de seus países. 
efetivamente com a técnica, e não apenas com o repertório” (ASSEF, 2003, p. 39), e assinou alguns discos de coletâneas ao longo da década, além de ter apresentado um programa televisivo na extinta TV RIO e o Som Livre Exportação, na Rede Globo. ${ }^{18}$

Sobre o repertório dos Bailes da Pesada, soul e rock possuíam o mesmo destaque na festa. Segundo o DJ Corello, em depoimento concedido a Assef (2003, p. 39), "Os dois tocavam na sequência coisas como Bobby Bloom [pop], Yes [rock] e Charles Wright [soul] sem que aquilo soasse estranho”, mas foi a black music que fez a fama do evento. Big Boy chegou a declarar à revista Rock, em 1974: "Eles querem é soul, e mesmo assim James Brown. Não aceitam música branca, mais lenta, sem a bateria marcada”. (ESSINGER, 2005, p. 30) Os bailes de Big Boy e Ademir Lemos se tornaram um marco na vida noturna do Rio de Janeiro, possibilitando que os dois discotecários se tornassem grandes nomes do show business nacional. Vianna (1988) ressalta que o evento atraía frequentadores tanto da Zona Sul quanto da Zona Norte da cidade, demonstrando uma frequência mais eclética e um mote mais democrático, o que foi um marco importante, pois "havia toda uma discriminação, o povo não atravessava o túnel”, como comenta a ex-esposa de Big Boy, Lúcia Duarte, em entrevista ao programa de TV De lá Pra Cá (2014). ${ }^{19}$

E já em 1970, lançaram, em LP, a coletânea Baile da Pesada (Top Tape, 1970), uma seleção do repertório musical que integrava o set list dos bailes, com faixas intercaladas por locuções e vinhetas mixadas às músicas, a fim de reproduzir em disco a atmosfera das domingueiras no Canecão. As faixas eram compostas por sucessos da soul music, mas também do pop-rock americano, gênero musical até então predominante dentre o segmento de música estrangeira que chegava ao Brasil. Esse formato de gravação em disco de coletâneas de músicas compiladas por um DJ, que ainda por cima dava nome ao disco, era ainda inédito no mercado brasileiro. E passou a ser um modelo recorrente, potencializando ainda mais a divulgação do nome do DJ ou da

18 No final dos anos 1980, Ademir Lemos lançou-se como cantor de funk, gravando, em 1989, a "Melô do Arrastão". Em 1991, lançou o disco Um senhor baile com o sucesso "Rap do Rapa", com samples das músicas "Money for nothing", do Dire Straits, e "Cocaine", de Eric Clapton.

19 Programa De Lá Pra Cá, com direção de Carolina Sá. TV Brasil, Rio de Janeiro, 23 jan. 2014. 25 min. 
equipe de baile e possibilitando que as pessoas levassem para casa as gravações que dançavam nas festas, além de aumentar a circulação dos catálogos e lançamentos das gravadoras.

Apesar do sucesso, os DJs ficaram impossibilitados de continuar no Canecão, cuja administração preferiu receber o cantor Roberto Carlos para uma longa temporada, o que ocuparia a agenda da casa inclusive aos domingos. ${ }^{20}$ Lemos, percebendo a adesão da população da Zona Norte, resolveu transferir suas festas para os clubes do subúrbio, com o objetivo de aproveitar o emergente mercado dos bailes black. Por já possuir um maior capital para investir em aparelhagens de som importadas e por também ter mais acesso aos últimos lançamentos da música negra norte-americana, sua equipe se tornou uma das mais bem-sucedidas da cena soul, cobrando em torno de mil dólares por um típico baile de final de semana. (MCCANN, 2002) Junto com Big Boy, decidiram excursionar por várias cidades, sendo pioneiros na realização de turnês nacionais só de DJs, trazendo para o trabalho do disc-jóquei o status de artista de sucesso. Outro DJ que alcançou fama e levou o soul para as boates da Zona Sul; também realizando bailes no subúrbio, foi Monsieur Limá, o Raimundo de Lima Almeida. Como Big Boy, Limá também apresentou programas de TV - Rio By Night Avec Monsieur Limá, na TV Tupi-, apresentando-se com roupas brilhantes e espalhafatosas com altos sapatos plataforma. (ASSEF, 2003, p. 40) O DJ também lançou várias coletâneas em disco e manteve-se em atividade com bastante sucesso no momento da transição do soul para a discoteque.

\section{Bailes $100 \%$ soul}

O crédito a Big Boy é importante para a compreensão daquele momento, pois foi o responsável pela difusão inicial da soul music no Rio de Janeiro em

20 Ademir Lemos, em depoimento a Vianna (1987, p. 51), conta sua versão do fato: “As coisas estavam indo muito bem por lá. Os resultados financeiros estavam correspondendo à expectativa. Porém, começou a haver falta de liberdade do pessoal que frequentava. Os diretores começaram a pichar tudo, a pôr restrição em tudo. Mas nós íamos levando até que pintou a ideia da direção do Canecão de fazer um show com Roberto Carlos. Era a oportunidade deles para intelectualizar a casa, e eles não iam perdê-la, por isso fomos convidados pela direção a acabar com o baile". 
uma época em que o acesso a uma produção midiática internacional era ainda difícil, especialmente para jovens da periferia. O rádio, pois, assumia um papel logo também adotado pelos disc-jóqueis dos bailes, de mediador e difusor de uma cultura globalizada por entre uma população menos favorecida. Com 20 e poucos anos, Oséas Santos também era um dos ouvintes de Big Boy. O jovem era morador de uma favela no Morro da Mineira, no bairro do Catumbi, Zona Norte do Rio de Janeiro, região periférica e marginalizada da cidade. Junto com alguns amigos, organizava pequenas festas de bairro - na época, chamadas de "festas americanas" ou "hi-fis" -, que eram reuniões informais em que os convidados levavam comida e bebida e dançavam ao som das últimas novidades da música norte-americana. O costume da realização de pequenas festas, bailes, quermesses que tocavam sucessos populares para o entretenimento de jovens dos subúrbios e periferias era algo frequente e constante, representando uma forma de lazer para um público de menor poder aquisitivo. ${ }^{21} \mathrm{O}$ jornalista, ator e cineasta independente Ras Adauto, que participou ativamente da Black Rio, aponta que o soul já se difundia pelo subúrbio desde os tempos da Jovem Guarda, em uma etapa posterior ao rock'n'roll:

\begin{abstract}
Eu venho de Padre Miguel e foi ali que eu ia às festinhas de um pessoal que fazia bailes nas suas casas. [...] Já tinham bailes nos subúrbios, como no Greip da Penha e em Realengo, que tocavam soul, e havia as festas soul nas casas das pessoas, no quintal, e depois isso 'desceu' para o centro. Os bailes nascem nos guetos e desaguam pelo Rio de Janeiro todo, $e$ foram capitalizados pelo pessoal das rádios da Zona Sul. ${ }^{22}$
\end{abstract}

21 É interessante notar como esse tipo de organização de evento cultural popular amador era também percebido no contexto americano, nas rent parties ou "festas de aluguel", realizadas nas favelas do Harlem ou de Chicago, no começo do século, em que negros se reuniam para ouvir e dançar jazz tocado ao vivo, nas block parties ou "festas de quarteirão", realizadas já nos anos 1960 e 1970, em espaços públicos como praças, parques e quadras esportivas em bairros negros americanos, animados por música eletrônica, e nos sound system jamaicanos, que se baseavam em sistemas de som potentes que animavam festas realizadas nas periferias de Kingstom desde os anos 1950. O som desses sistemas sonoros possuía características particulares como a ênfase nas frequências de graves e na questão estética, possibilitando novas formas de consumo popular. (GILROY, 2001)

22 Jornalista e militante. Entrevista concedida à autora por telefone, Rio de Janeiro, em 2 fev. 2016, telefone. 
Já nos anos 1960, Assef (2003, p. 25) menciona a existência de vários DJs e grupos de baile em São Paulo que realizavam festas soul e samba-rock como os Black Brothers, Os Primus, Lancaster e Sacudim, dentre outros, já em um formato mais profissional em relação ao contexto carioca. Nos bailes suburbanos do Rio de Janeiro, naquele tempo, o que agitava as pistas era a prática da dança entre casais formados, em sua maioria, por negros pobres e de classe média baixa, ao som de hits dançantes da MPB, sambas e musicas românticas internacionais. Mas já havia influências do soul americano em noites animadas por grupos como Devaneios, Brasil Show, Copa 7 - ainda hoje em atividade - e os conjuntos de Ed Lincoln e Lafayette. Como sinaliza Essinger (2005, p. 15), "Era o programa certo para todos os fins de semana do ano, mais até do que as rodas de samba, às quais o subúrbio sempre é associado”.

Para a jornalista e crítica Ana Maria Bahiana (1980, p. 49), os bailes de soul

surgiram exatamente dos bailes de rock, prática comum nos subúrbios cariocas e paulistas no início da década. Com grupos ao vivo e depois, cada vez mais, com música em fita, esses bailes misturavam, inicialmente, rock e soul, escolhidos pelos padrões mais dançáveis.

Ao final dos anos 1960, quando o rock deixa de assumir contornos mais dançáveis, passa a ser maciçamente substituído pelo soul e por uma produção pop dançante brasileira - de artistas como Wilson Simonal, Jorge Ben Jor e The Fevers. Esse movimento de bailes voltados para um público negro, animados por música norte-americana, também já ocorria em São Paulo desde 1967, segundo Silva (1998, p. 73), quando foi criada a Chic Show, primeira equipe profissional de baile a se formar na cidade voltada para o segmento da black music, logo seguida por outros empreendimentos, como as equipes Black Mad e a Zimbabwe, ambas criadas em 1975.

Foi nas pequenas festas do subúrbio, por volta de 1969, que Oséas deu seus primeiros passos como disc-jóquei, tocando seus discos em uma vitrola barata. Oséas era uma espécie de líder de uma turma de roqueiros do Morro da Mineira e idolatrava Led Zeppelin e Jimi Hendrix, mas já ostentava um grande penteado afro. Até então, o jovem trabalhava como auxiliar de palco de um grupo de carioca de rock e, logo depois, foi contratado para prestar 
serviço para a então famosa banda de Jovem Guarda Renato e seus Blue Caps. Nessa função, aprendeu a trabalhar com som e iluminação, o que possibilitou um conhecimento fundamental para o sucesso de seus bailes. Com a fama nas redondezas dos hi-fis que organizava, o jovem resolveu arriscar, inspirado pelos bailes de Ademir Lemos, de quem era fã confesso: "Ele foi meu ídolo, esteve sempre à frente". ${ }^{23}$ (ASSEF, 2003, p. 47) Junto com sete amigos, alugou alguns aparelhos de som primitivos e pouco sofisticados - mais exatamente dois toca-discos, alguns amplificadores e seis caixas de som, segundo Essinger -, contando com a boa vontade dos donos do Astória Futebol Clube, que cederam o espaço por uma noite para a realização de um baile maior. Construído na década de 1930, o clube chegou a abrigar um time de futebol e conquistou alguns títulos de importância local. Frequentado pela classe média da região, começou a entrar em declínio nos anos 1970, e a realização de bailes populares era uma alternativa para conseguir mais dinheiro para a manutenção das instalações. Para Frias (1976, p. 4), o DJ contou como ajudou a criar um nicho de mercado:

Comecei fazendo um soul diferente do de Big Boy. Era o seguinte: o soul que Big Boy lançava era bacana, mas não era aquilo que o pessoal queria. Ele tinha uma boa discoteca, mas começou a ficar ultrapassado, porque o negócio dele era mais comercial. Aí eu entrei com um soul pesado, marcado, e apanhei o público de Big Boy. É por isso que a rapaziada me considera assim uma espécie de pai do soul. Comecei a descobrir nas importadoras um som que ninguém curtia. Foi em cima desses que eu fiquei.

O dinheiro angariado com a venda prévia de ingressos deu apenas para financiar o som, e a iluminação foi feita só com um feixe de luz sobre todo o salão: "era uma pessoa em cima de uma cadeira fazendo movimentos, essa era a iluminação", lembrou Dom Filó em entrevista ao programa Caminhos da reportagem, em 2014. A precariedade da estrutura não impediu que comparecessem à festa em torno de 1.500 pessoas, um sucesso para os padrões

23 Depoimento de Mr. Funky Santos publicado no livro Todo DJ já sambou: a história do disc-jóquei no Brasil, de Assef (2003). 
da época, especialmente por não ter havido uma maior divulgação além do "boca a boca" informal. Para animar o público quase majoritariamente negro, Oséas fazia a mixagem das músicas na chave do próprio amplificador e, além de discotecar, descia do palco e conversava com os frequentadores, como um mestre de cerimônias. Mesmo tendo prejuízo, esse primeiro baile fez história, e o até então disc-jóquei amador decidiu se profissionalizar e fundou sua primeira equipe, a Pôr do Som: "Então Santos e a Equipe Por do Som foi a primeira festa black, a primeira festa negra, $100 \%$ negra nesse país”. ${ }^{24}$ (RIBEIRO, 2008, p. 109) Outros nomes para o empreendimento foram adotados, como Santos Equipe, Curtisom, Santos Equipe de Soul, Brazilian Santos, "até que alguém lá falou que eu era o Mister Funky Santos e o negócio começou a fluir”. ${ }^{25}$ (ESSINGER, 2005, p. 18)

Escolhido o nome artístico e comandando sua própria equipe, Mr. Funky Santos passou a realizar diversos bailes em outros clubes do subúrbio nos finais de semana, buscando difundir uma sonoridade soul mais pesada e dançante, descobrindo em lojas de vinis importados, como a Billboard - que importava discos para Big Boy -, Modern Sound, Symphony, King Karol, gravações que ainda eram novidade nas pistas do Rio de Janeiro. Essas lojas, todas localizadas na Zona Sul da cidade, atraíam também DJs de São Paulo e de outros estados.

Mr. Funky pode ser considerado um dos pioneiros na criação de um produtivo modelo de entretenimento alternativo no Rio de Janeiro, e os bailes no Catumbi incentivaram a realização de festas em outros locais do subúrbio, com a criação de novas equipes, como Uma Mente numa Boa, Uagir, Black Power, Cash Box, A Cova, dentre muitas outras. Os bailes, como modos de lazer popular e espaços de consumo de novas modas musicais e culturais no Rio de Janeiro, como em outras áreas urbanas do Brasil e da América Latina, não eram uma novidade em si. Nem tampouco a composição étnica do público era um diferencial, já que eventos dançantes voltados para populações negras eram uma tradição carioca desde a abolição, como foi visto no capítulo "Bailes e clubes de subúrbio". A grande diferença, a partir dessas experiências

24 Entrevista de Mr. Funky Santos.

25 Entrevista de Mr. Funky Santos. 
iniciais, residia no fato de que os bailes nos quais se podia ouvir e dançar o soul americano começaram a ser reproduzidos em outros pontos da cidade, indo além da Zona Norte, difundindo um estilo e estimulando a criação de uma cena paralela de entretenimento e consumo periférico na cidade.

\section{As Noites do Shaft e o Clube Renascença}

Foi após uma ida a um baile de Mr. Funky Santos, no Clube Astória, que Dom Filó teve a ideia de levar para o Clube Renascença uma proposta semelhante: "Vimos que poderíamos fazer a mesma coisa no Renascença, mas com um diferencial: a consciência negra”. ${ }^{26}$ (ESSINGER, 2005, p. 19) Em 1972, o Clube Renascença - antiga associação criada no Andaraí, Zona Norte do Rio, por uma classe média negra local - foi escolhido para ser o espaço de realização de uma festa com um mote marcadamente voltado para conscientização racial: as Noites do Shaft. Fazendo referência ao personagem do seriado homônimo americano, essas festas eram utilizadas por seus organizadores para propagar um discurso politizado, voltado para a formação e a valorização de uma nova imagem do negro, influenciados pela ideologia do movimento Black Power norte-americano. O Poder Negro, em sua acepção original, se referia a um conjunto de ideias e valores de afirmação e orgulho negro desenvolvido na década de 1960, tendo como um de seus principais idealizadores Stokely Carmichael, que difundia a crença da superioridade das culturas negras de origem africana.

A própria escolha do nome do evento já representava uma proposta diferenciada, mais popular e uma articulação com símbolos internacionais. Shaft era o nome do personagem principal do filme de mesmo nome, que contava as aventuras de um detetive negro, que propunha uma visão positiva e um protagonismo do negro em uma narrativa relacionada às experiências das populações negras norteamericanas. O filme, protagonizado pelo ator Richard Roundtree, ganhou três sequências dirigidas por Gordon Parks. Lançado pela MGM em 1971, teve um grande orçamento e recebeu o Oscar de melhor canção no ano seguinte com uma composição de Isaac Hayes, um dos

26 Depoimento de Dom Filó publicado no livro Batidão: uma história do funk, de Essinger (2005). 
maiores nomes do soul norte-americano e um dos artistas mais engajados da época. Sucesso comercial e de crítica, Shaft (Stax Records, Entreprise Records, 1971) é o trabalho mais conhecido de Hayes, que deu nome ao disco mais lucrativo lançado pela gravadora de black music Stax. Esse foi também o primeiro álbum duplo de estúdio de um artista de Rhythm \& Blues (R\&B). ${ }^{27}$ O filme notabilizou-se por lançar um herói negro, quase um similar de James Bond, porém carregado do linguajar das ruas, mostrando um estilo comportamental e uma moda típica dos guetos urbanos afro-americanos. Shaft pode ser considerado um dos primeiros filmes que inaugurou a vertente chamada blaxploitation.

A iniciativa de criar um evento com o título do filme para celebrar o orgulho negro foi do estudante de engenharia Asfilófio de Oliveira Filho, conhecido como Dom Filó, que conseguiu convencer a diretoria do Renascença a ceder o clube para a realização de eventos culturais que atuassem como formadores de uma consciência racial e social junto à comunidade negra. A primeira atividade foi a montagem do espetáculo musical Orfeu da Conceição, de Vinícius de Moraes, com atores negros que haviam formado um grupo de teatro do qual faziam parte nomes como Antônio Pompeu, Zózimo Bulbul e Zezé Motta. Dirigido por Haroldo de Oliveira, o elenco da peça também contou com não atores frequentadoras do clube, e o cenário teve a assinatura da arquiteta Vera Figueiredo, com trilha sonora do maestro Paulo Moura. A montagem chegou a ser encenada, posteriormente, no Teatro Tereza Raquel, em Copacabana. No entanto, o espetáculo não atraiu o público esperado ${ }^{28}$ e Dom Filó, ao se tornar diretor artístico do clube, junto com o ator Haroldo de Oliveira, teve a ideia de organizar grandes bailes para, através deles, propagar mensagens de valorização da cultura negra aos frequentadores. Por meio dessas festas, seus organizadores tentavam difundir um discurso mais

27 O disco atingiu o número um da The Billboard 200 e passou 60 semanas no topo das paradas norte-americanas. Os singles de "Theme from Shaft" e "Do your thing" também entraram no ranking Top 40 da parada Billboard Hot 100.

28 “[...] então a gente montou o Orfeu, aí tudo bem, um espetáculo maravilhoso, um sucesso, mas jovem negro nenhum. Ninguém tava [sic] ligado nesse troço de cultura. Eu com aquilo compreendi e entrei numa de fazer som" (Jornal de Música apud VIANNA, 1987, p. 55), conta Dom Filó em entrevista ao Jornal da Música em 1976. 
politizado, voltado para a formação e a valorização de uma nova imagem do negro. Lemas do movimento Black Power, como "I am somebody" e "I'm black and I'm proud", passaram a ser incorporados pelos frequentadores, representando uma aplicação da ideologia norte-americana do Poder Negro na vida cotidiana de jovens negros cariocas. O baile foi um sucesso e passou a atrair não somente os jovens frequentadores do Renascença como também a juventude negra de comunidades de pobres do entorno como Engenho Novo, Vila Isabel, Salgueiro, Morro dos Macacos, Andaraí, Pau da Bandeira e Cachoeirinha. (GIACOMINI, 2006, p. 210)

O Clube Renascença já levantava a bandeira da valorização da cultura negra desde sua criação. Fundado em 17 de fevereiro de 1951, a agremiação reunia, na época, 29 sócios, 11 homens e 18 mulheres, todos negros, que buscavam reforçar a existência de uma "elite" negra, em vias de ascensão social. De fato, a primeira diretoria do Renascença era composta por profissionais liberais que possuíam títulos universitários, o que era um grande diferencial quando se pensa no índice de escolaridade média da população carioca e, em particular, da população negra brasileira na época. Dentre as profissões dos coordenadores do Renascença, estavam um ourives, duas médicas, um médico, um professor de música e um advogado, que presidia a chapa da direção. Apesar do bom nível de escolaridade e de já integrarem uma classe média emergente, esses indivíduos não eram aceitos nos clubes tradicionais em função de sua cor. E o Renascença foi criado com o propósito de servir como espaço de convivência comunitária e também um local de resistência, conscientização e valorização racial.

Localizando-se inicialmente no bairro de Lins de Vasconcelos, o clube foi posteriormente transferido para o Andaraí, ambos bairros da Zona Norte, próximos ao centro. Essa região era tradicionalmente habitada por uma classe média e média-baixa e representava uma área de encontro entre "o morro e o asfalto”, também concentrando um emergente grupo de famílias negras em ascensão formadas por profissionais liberais, funcionários públicos e militares. O nível de renda e escolaridade de seus fundadores também ajudou a determinar um viés político-ideológico da vida social do clube nos seus primeiros anos, marcado por atividades que preenchiam rotineiramente a vida social dos seus associados desde que contribuíssem para "o aprimoramento 
dos jovens e estimulassem a socialização e difusão de certos símbolos da cultura clássica ou erudita”, como pontua Giacomini (2006, p. 32).

É importante frisar aqui que essa cultura "clássica" e "erudita" podia embaralhar tanto produtos culturais característicos de uma elite ocidentalizada - como a prática esportiva do xadrez, a leitura de cânones literários, a audição de música erudita tradicional -, como também se referia ao contato com textos produzidos por teóricos da negritude, enquanto corrente literária, como a obra do poeta antilhano Aimé Césaire e do político e escritor senegalês Léopold Sédar Senghor, ligados também ao movimento pan-africanista. A articulação a correntes clássicas ideológicas do pensamento racial estava inclusive representada na própria escolha do nome da agremiação. O Renascença teve seu título inspirado no movimento artístico-literário Harlem Renaissance, promovido nos anos 1930 no bairro negro nova-iorquino do Harlem por intelectuais negros como forma de criticar a discriminação racial e a desigualdade econômica, buscando uma autonomia e uma originalidade cultural para a população afro-americana. Os integrantes do clube Renascença, assim, se alinhavam a bases ideológicas clássicas ocidentalizadas que buscavam uma valorização do homem negro a partir da construção de um pensamento erudito como forma de afirmação e legitimação em sociedades racializadas.

A proposta da consolidação de uma elite intelectual negra, da mesma forma que era pensada no Harlem Renaissance, também encontrava ecos na configuração de um projeto para os frequentadores do Clube Renascença como um espaço de distinção. Diferentes formas de sociabilidade e de eventos festivos foram experimentadas, revelando, igualmente, distintas concepções de público e privado e também do que seria "ser negro". Efetivamente, o Renascença, em suas práticas iniciais, programações culturais e eventos sociais, reproduzia formas de exclusão ou de separação entre trabalhadores proletários e a pequena burguesia negra em ascensão que compunha seus associados, de maneira bastante semelhante ao que ocorria nos clubes da elite branca que barravam o ingresso de negros, conforme aponta Martins (2010, p. 122).

Nos anos 1960, uma mudança de rumos promove uma "popularização" das atividades do Renascença, com a incorporação de rodas de samba com artistas famosos e dos concursos de misses negras, muito valorizados na época, 
que obtiveram grande sucesso e apoio popular geral. Inclusive, uma das misses do Renascença, Vera Lucia Couto, foi vencedora do concurso de Miss Estado da Guanabara e ficou em segundo lugar no Miss Brasil de 1964. De fato, entre os anos 1960 e 1970, o clube integrou-se à geografia da cidade, cuja fama e a frequência ultrapassou os limites do subúrbio carioca. A festejada eleição de Vera Lúcia Couto como Miss Guanabara foi vista por muitos, se não pela maioria dos sócios, como uma vitória da negritude, quase um resultado memorável do esforço coletivo do grupo.

Por conta do sucesso de suas misses, o Renascença passaria a ser conhecido - e também reconhecido por seus próprios associados - como o "clube das mulatas”, o que, na época, foi alvo de julgamentos contraditórios. Um dos críticos dessa vertente era Dom Filó, que já desenvolvia um trabalho voltado para o combate à Doença de Chagas nas comunidades no Morro dos Macacos, em Vila Isabel e no Salgueiro. Filó teve uma trajetória atípica para um jovem negro da época. Nascido em 1949, passou a adolescência no bairro do Jacaré, Zona Norte. Filho de mãe empregada doméstica, o pai era mecânico e entrou no ramo de compra e venda de carros, até se tornar um bem-sucedido dono de uma agência de automóveis. A melhora nas condições de vida possibilitou que a família matriculasse o filho no curso de Engenharia Civil em uma faculdade particular, a Fundação Souza Marques - que era propriedade de uma família negra. Filó conta que "lá, entre os 43 alunos da turma, só havia quatro negros. Eu e outros três, todos eles militares. Eu com meu cabelo black power - e, às vezes, com tranças de barbante - tamanco, bolsa de pano, calças pantalonas. Era hippie”. (ALMADA, 2013) Além de estudar, Filó também comprava e revendia calças Lee, muito desejadas na época, além de perfumes importados, como o argentino Lancaster, para ajudar nas finanças. Ao completar 18 anos, ganhou um carro do pai, o que deu a Filó certa facilidade para circular pela noite carioca, conhecendo diferentes espaços de lazer, entretenimento e boemia.

Eu, de carro, me deslocava tanto para os bailes de grupos musicais como o Copa Sete, Devaneios, Lafayete, The Pops, na Zona Norte, como para o Beco da Fome, na Zona Sul da cidade, onde se reuniam artistas, e conheci gente como Jorge Ben Jor, Tim Maia, entre 
muitos outros. Minha identificação era com os bailes de dança de salão, mas isto antes de conhecer o soul. (ALMADA, 2013)

O Beco da Fome, contemporâneo do Beco das Garrafas, também se localizava em Copacabana, mas permaneceu em atividade após os anos 1960. Estava localizado na Rua Prado Júnior e reunia profissionais que trabalhavam até tarde da noite ou na própria noite, como jornalistas, policiais, cafetões e pessoas envolvidas com atividades de origem duvidosa. No Beco, estavam localizadas em torno 18 cantinas, que ofereciam cardápios a preços populares, e muitos músicos frequentavam o local após seus shows, bem como diversas outras pessoas em busca de um local alternativo para a diversão - o espaço foi destruído e hoje em dia dá lugar a um edifício. Além de frequentar diferentes pontos da noite carioca, Filó também se interessava pelas obras de intelectuais negros, como os americanos Malcolm X e Martin Luther King e os africanos Agostinho Neto e Samora Machel - respectivamente, os primeiros presidentes de Angola e Moçambique. No Renascença, realizava palestras e exibia alguns filmes de jazz cujas cópias eram cedidas pelo Instituto Cultural Brasil-Alemanha (ICBA), mas foi por meio dos bailes que percebeu um potencial maior de conscientização. Se nos anos 1950 a referência do Renascença era uma classe média idealizada, amante de saraus, e nos anos 1960 o projeto do clube tinha uma inclinação para a celebração da cultura negra nacional, nos anos 1970, buscou-se uma prática fora dos modelos consagrados, seguindo os passos dos movimentos negros norte-americanos e flertando com algumas propostas ideológicas do grupo Black Panthers. Isso também gerava conflitos e tensões entre as gerações mais velhas do clube, que inicialmente não toleravam ceder o espaço para um evento festivo tido como menos legítimo e distante da tradição. Os choques geracionais provocados pelo soul também se relacionavam à forma como os bailes abordavam abertamente as questões da autoestima negra e da luta contra o racismo, de acordo com Hanchard (2001, p. 136): "Em muitas ocasiões, as moças e rapazes que participavam do Black Soul entraram em conflito com os pais ou se viram como catalisadores de familiares que, até então, nunca haviam enfrentado as questões de opressão e identificação raciais”. Essa nova geração que passou a organizar e modificar a programação cultural do clube era influenciada por 
outros valores e visões. Dom Filó, juntamente com seus amigos, pensava em novas formas de ocupar aquele espaço sem abrir mão do mote que havia marcado a história do clube.

Eram herdeiros, mas também críticos da tradição construída ao longo da história do Renascença, oriundos de uma classe média negra emergente, alguns estudantes de cursos universitários. Alguns poucos tinham acesso a espaços sociais e de lazer da elite da Zona Sul carioca, e acesso à informação e geral, que vão, aos poucos, construir um projeto cultural e político com um cunho militante objetivando contribuir para a criação de uma consciência negra e para a constituição das primeiras bases de um movimento negro organizado. (GIACOMINI, 2006, p. 190)

Os bailes black passaram a disputar espaço, atenção e simpatia com as tradicionais rodas de samba realizadas no Renascença. Para Giacomini (2006), esse momento foi conflituoso, pois, na construção das acepções de uma identidade negra para o clube e seus sócios mais antigos, havia uma oposição a um sentimento racial importado dos Estados Unidos e presente no consumo da soul music, a despeito do fato de que a associação foi inicialmente influenciada por intelectuais afro-americanos clássicos ligados ao Harlem Renaissance. Para as gerações mais antigas de sócios, a construção da identidade negra deveria ser pensada a partir de traços mais nacionais e locais, como o samba, que seria uma manifestação cultural mais autêntica. Mas essas discussões internas não impediram o sucesso das Noites do Shaft, que durou três anos, sendo realizadas todos os domingos ininterruptamente. Mais que um simples baile, o evento emulava uma nova maneira de ser negro, apresentando um universo contemporâneo de imagens e referências e rejeitando o lugar a que se pretendia tradicionalmente atribuir o negro brasileiro, ligado a símbolos como samba, morro, favela, carnaval.

Com o foco na autoestima, a equipe de produção das Noites do Shaft definiu uma estratégia para os bailes, que deveriam ser mais diretamente vinculados a questões políticas e raciais a partir da articulação a uma cultura massiva afro-americana. Com vistas a alcançar esse objetivo, um dos pontos altos da festa era a projeção de slides em um paredão branco, com imagens retiradas 
de revistas americanas voltadas para o segmento negro, como a Ebony, ${ }^{29} \mathrm{du}-$ rante a execução das músicas. Naquele tempo, o acesso a publicações internacionais era restrito, e encomendas eram feitas a raros viajantes ou a aeromoças e comissários de bordo, que traziam algumas edições clandestinamente, junto com vinis contrabandeados. Também era possível encontrar edições da Ebony em bancas que vendiam jornais e revistas importadas na Avenida Rio Branco, no centro da cidade. O mero ato de adquirir um exemplar já era uma atitude de tomada de posição política, como aponta Carlos Alberto Medeiros, militante negro, em depoimento a Alberti e Perreira (2005, p. 3):

Eu passava e via a revista, tinha até alguma curiosidade. Mas é interessante isso: até para comprar a revista a primeira vez, eu tive que romper com alguma coisa. Porque você comprar uma revista de negros tinha um significado de identificação.

Medeiros se formou em jornalismo e atuou politicamente em diversas áreas, contribuindo com muitos dos projetos culturais de Dom Filó ao longo dos anos.

Além das fotos, nos bailes, eram projetados trechos de Shaft e de outros filmes representantes do cinema blaxpoitation, como Super fly e Wattstax. Wattstax, em particular, teve um papel importante para o movimento black, oferecendo imagens, discursos e músicas aos frequentadores dos bailes. Considerado o Woodstock negro, o documentário foi lançado em 1973 e não teve exibição comercial no Brasil, sendo mostrado em alguns bailes - na íntegra ou parcialmente -, com direção de Mel Stuart, que ficou famoso ao dirigir o filme A fantástica fábrica de chocolate, em 1971. O documentário registrou o festival de música negra realizado em 1972, no pequeno bairro periférico de Watts, em Los Angeles, organizado pela gravadora Stax - na época, a principal concorrente da Motown no mercado da black music. O show era uma forma de homenagear a comunidade, que, em 1965, foi palco da Revolta Popular

29 Ebony é uma revista mensal voltada para o público afrodescendente, criada por John Harold Johnson em 1945 nos Estados Unidos e publicada até os dias atuais. Sua proposta era dar visibilidade à população afro-americana, e suas capas são dedicadas a atores, músicos e políticos negros do país. 
de Watts, um dos mais sangrentos conflitos raciais ocorridos na história dos Estados Unidos. Mas também foi uma ação de marketing interessante para divulgar o casting da gravadora a partir de um concerto com suas maiores estrelas. O público presente pôde ouvir grandes sucessos do soul, funk, gospel e blues, e a iniciativa serviu como estratégia para vincular a imagem da Stax à comunidade negra e pobre dos Estados Unidos, em oposição à Motown, que cada vez mais se voltava para o segmento consumidor pop-branco americano. Wattstax ainda mesclava as apresentações musicais com imagens da plateia e do bairro, além de intercalar depoimentos de membros da comunidade negra de Watts com esquetes de comédia do famoso comediante negro Richard Pryor, criticando o racismo e analisando com humor alguns traços da cultura negra norte-americana. O documentário captava bem o clima da época e retratava o estilo dos habitantes locais, divulgando também frases do movimento pelos direitos civis, como "I am somebody", lema que integra o célebre discurso do reverendo William H. Borders, escrito nos anos 1950, proferido no documentário por Jesse Jackson, pastor batista e ativista político norte-americano.

Nos bailes do Renascença, também eram exibidas fotos de astros da black music, como James Brown, Jackson Five e Diana Ross, e de atletas, como Muhammad Ali, a fim de inspirar a plateia com as conquistas políticas e as construções estilísticas dos negros norte-americanos, "fazendo uma espécie de introdução à cultura negra por fonte que o pessoal já conhece, como a música e os esportes", justificou Filó em entrevista ao Jornal da Música. (VIANNA, 1987, p. 55) E mescladas às imagens de celebridades - algumas poucas brasileiras, como Pelé -, eram mostradas também fotos dos próprios frequentadores dos bailes, relacionando aqueles ícones com suas próprias experiências. "Você se via na tela, a autoestima aumentava e aquilo trazia mais gente. Foi uma bola de neve". ${ }^{30}$ (ESSINGER, 2005, p. 22)

Era fascinante para os novatos e deixava ansiosos mesmo os frequentadores mais experimentados. Estar bem composto no estilo Shaft, mais que necessário, era particularmente compensador e gratificante,

30 Depoimento de Dom Filó publicado na obra de Essinger. 
o que se entende quando se tem em vista a organização e apelos da festa: slides projetados nas paredes exibiam, alternadamente, imagens do Shaft e closes dos frequentadores. Nesses instantes, o participante se via em tamanho aumentado e era visto por todos. Celebrados e cotejados, lado a lado, o Shaft e o anônimo participante da festa, ambos nas mesmas dimensões, em cada qual igualmente presentes os signos que expressavam a adesão comum ao soul, à alma e ao orgulho negros, sintetizados e coagulados, de maneira perfeita, na figura do Shaft. (GIACOMINI, 2006, p. 195-196, grifo do autor)

Além da exibição das imagens, Dom Filó interrompia a discotecagem e passava algumas mensagens, que também eram mostradas nos slides, como "O seu cabelo cresce dia-a-dia, mas o mais importante é o que está debaixo desse cabelo. O que você esta pensando do futuro?" e "Nós temos que nos organizar como negros, senão nós não vamos chegar lá”. (ESSINGER, 2005, p. 22-23) Temas como estudo, família, abuso de drogas e violência também eram abordados, em uma visão positiva dentro de uma perspectiva de ascensão social associada ao orgulho negro. E alguns ativistas negros começaram a utilizar os bailes soul como locais para buscar adeptos. Não era incomum ver em alguns bailes jovens militantes distribuindo exemplares de livros como Black Power, de Stokely Carmichael, e Os condenados da Terra, de Frantz Fanon (HANCHARD, 2001, p. 138), obras de líderes negros que discutiam a questão racial e o combate ao racismo. É importante enfatizar que, mais do que outros bailes soul da época, as Noites do Shaft tinham uma vinculação maior com a questão política negra, não apenas por serem realizadas em um clube de negros que tinha uma trajetória de valorização da questão racial, mas por serem organizadas por jovens já ligados a uma militância, ainda em fase de reorganização. Carlos Alberto Medeiros ${ }^{31}$ assume:

Eu entrei no movimento negro via baile. O mais interessante é que minha trajetória no movimento negro começou frequentando as Noites do Shaft. Foi em uma ocasião em que fiquei sabendo de uma reunião que seria realizada no Centro de Estudos Afro-Asiáticos, da Universidade

31 Jornalista e militante. Entrevista concedida à autora, em 5 dez. 2016, no Instituto de Filosofia e Ciências Humanas, UFRJ, Rio de Janeiro. 
Cândido Mendes, em Ipanema. Decidi ir a esse encontro, e a partir dali me tornei um militante.

Dom Filó, da mesma forma que Mr. Funky, criava uma nova forma de atuar, ultrapassando o simples papel de tocar músicas. Naquele tempo, os DJs, mesmo que famosos, tocavam de costas para o público, de acordo com Essinger (2005, p. 19). Mas, nos bailes soul, os disc-jóqueis desenvolviam performances diferentes e assumiam uma função de animadores, mestres de cerimônias, se tornando celebridades. Especialmente a questão da autoestima estimulada pelos produtores das Noites do Shaft influenciou muitas outras equipes, que, em seus bailes, passaram a premiar os cabelos "blacks" mais bonitos, ou realizavam concursos para escolher os frequentadores mais parecidos com astros do soul, como Isaac Hayes ou James Brown. No baile da SGP no Mourisco em 1976, o participante mais parecido com Isaac Hayes concorria a uma caderneta de poupança no valor de mil cruzeiros como prêmio. (FRIAS, 1976, p. 3) Já em outros eventos, as premiações eram destinadas aos melhores dançarinos. Essa valorização também das pessoas comuns ao lado dos artistas famosos era uma estratégia também adotada nos próprios panfletos e cartazes de divulgação das festas, em que fotos de frequentadores ilustravam as peças publicitárias junto com rostos de celebridades dos bailes, como o cantor Tony Tornado e o DJ Monsieur Limá.

O fato de ser um dos poucos jovens negros a possuir um carro na época permitia que Filó circulasse pela noite carioca e descobrisse onde poderia conseguir discos inéditos para seus bailes, desenvolvendo novas oportunidades de negócios na área da cultura e do entretenimento. O soul ainda era um gênero pouco explorado em termos de segmento noturno, pois não era a música mais tocada nas boates e emergentes discotecas da Zona Sul. Disc-jóqueis de casas famosas, como Le Bateau, Jirau, One Way, dispensavam os discos de soul que chegavam, e os DJs dos bailes black começaram a negociar para conseguir esse material, criando canais exclusivos de acesso às novidades do gênero. "Chegava muito material black e eles só tocavam Sex Machine”. ${ }^{32}$ (ESSINGER, 2005, p. 19-20) E, desse modo, nomes do soul

32 Depoimento do Dom Filó. 
norte-americano, como Rufus Thomas, Isaac Hayes e Aretha Franklin, passaram a fazer parte do acervo dos DJs cariocas do subúrbio e do gosto de milhares de frequentadores dos bailes.

\section{O soul em alta velocidade}

As Noites do Shaft fizeram enorme sucesso, e o baile passou a não mais caber no Renascença. Em 1975, a mudança para outros espaços, como o Clube Maxwell e o Cascadura Tênis Clube, acarretou modificações na produção da festa, além de gerar um aumento do público. A mensagem política direta presente nos discursos contra o racismo e nas imagens teve que ser amenizada para que o baile pudesse ser realizado em clubes de classe média da Zona Norte, frequentados por um público mais misto. Dom Filó, junto com alguns amigos, decidiu então criar a equipe Soul Grand Prix, que tinha como slogan "Soul em alta velocidade". Sem abandonar a estratégia da projeção de imagens de temática negra durante os bailes, estas passaram a ser alternadas com cenas de pilotos de Fórmula Um, esporte muito em voga na época. Essa estratégia ajudava a dar um tom menos politizado ao baile, agora mais frequentado por jovens brancos. (HANCHARD, 2001, p. 136) Entretanto, o mote da conscientização racial não foi totalmente abandonado, e as festas organizadas pela SGP continuaram a ter uma pretensão mais didática. Projeções de personalidades negras continuaram ilustrando os bailes, com fotos de músicos como Duke Ellington e Dizzy Gillespie, em uma espécie de introdução à cultura negra.

A SGP se estruturou como uma das principais equipes de som do Rio de Janeiro e fez história no universo do entretenimento carioca, desencadeando uma nova fase da cena Black Rio. (FRIAS, 1976, p. 4) A equipe foi a primeira a realizar bailes também na Zona Sul, em bairros como Botafogo, Horto e Jardim Botânico. Em seu auge, a equipe era composta por um DJ principal, Luizinho, enquanto a parte empresarial ficava a cargo de Nirto Batista de Souza, primo de Dom Filó, que criou alternativas comerciais para o crescimento da equipe, produzindo bailes cada vez maiores e mais lucrativos em vários pontos da cidade, todos os dias da semana, sempre lotados. (VIANNA, 1987, p. 54) 
A equipe conseguiu o patrocínio de uma loja no Leblon, Curtisoul, que comprou o equipamento de som e deu o nome ao empreendimento, mas que logo foi substituído por "Soul Grand Prix". A mudança do nome da equipe não agradou aos donos da loja, que resolveram acabar com a parceria e pegaram de volta os equipamentos. Então, de forma artesanal, Nirto e Luizinho uniram duas caixas de som, com quatro woofers de 12 polegadas cada uma, em um sistema de som amador, mas que podia ser transportado facilmente, facilitando a circulação da equipe pelo subúrbio. Outras equipes copiaram a ideia, mas com equipamentos cada vez maiores e mais potentes. "As equipes passaram a empilhar caixas de som, formando enormes paredes ou muralhas que se tornaram marca registrada desses bailes". (HERSCHMANN, 2000, p. 23) Os também chamados "paredões de som" podiam ser dispostos de acordo com o espaço disponível, espalhados pelo salão ou montados um sobre os outros como um jogo de blocos. Na contracapa do LP de 1978 da Furacão 2000 (ABC Records - Phonodisc), Rômulo Costa escreve:

São 50 caixas de som em suspensão acústica, 8 caixas de som para acústica, mesa de som com 19 canais, câmara de eco para efeitos especiais, 16 amplificadores transistorizados de 250 watts cada, sofisticado sistema de iluminação que vai das luzes rítmicas às cadavéricas [...].

Com o aumento dos lucros, a SGP adquiriu um sistema de som e luz mais poderoso, incluindo luzes estroboscópicas e projetores coloridos, dando ao baile uma atmosfera pirotécnica e onírica, inspirada também na ambientação das recentes discotecas. Outra característica da equipe foi o desenvolvimento de estratégias de marketing alternativas para divulgar a marca dos seus bailes, que contavam não apenas com o carisma do mestre de cerimônias Filó, mas também com um visual diferenciado ostentado pelos integrantes da equipe, que também contava com um grupo de dança chamado Angola Soul, com uma média de 30 integrantes, que animavam os bailes. Duplas e grupos de dança eram um recurso frequentemente utilizado por algumas equipes. Em geral, não eram bailarinos formais, mas fãs que compareciam frequentemente aos bailes e chamavam a atenção pela maestria na dança e pela aparência, 
sendo contratados informalmente pelos donos das equipes - muitas vezes pagos apenas com discos ou entrada gratuita nos bailes. Outra marca que tornou os bailes da SGP famosos eram as intervenções realizadas no meio do baile, que sempre aconteciam entre meia-noite e duas da manhã. Um hit musical dançante e "explosivo" sinalizava esse ápice, com luzes estroboscópicas que começavam a piscar com mais intensidade, enquanto uma chuva de filipetas era disparada: era o auge do baile. Esse momento poderia corresponder à execução de músicas famosas, como os hits "Soul Power" ou "Sex Machine", de James Brown. Esse tipo de apresentação, junto com a utilização de grandes conjuntos de caixas de som, acabou se tornando um padrão incorporado por todas as equipes de soul, com algumas variações, e vigora até hoje nos bailes funk e em outras festas periféricas contemporâneas disseminadas pelo país, como nas festas de aparelhagem de tecnobrega no Pará, na cena reggae maranhense e nos shows de forró eletrônico do Nordeste.

A SGP tornou-se um empreendimento grande e lucrativo e seus promotores resolveram investir diretamente no mercado fonográfico, lançando seu primeiro LP com os principais sucessos do baile em 1974, pela Top Tape, produzido por Ademir Lemos. Segundo Frias (1976, p. 3), a equipe entrava com o nome e ganhava um cruzeiro por LP editado, e as faixas eram selecionadas de discos americano. Dois anos depois, a convite do famoso executivo da Warner, André Midani, a SGP lançou seu segundo álbum, que recebeu o disco de ouro. Em 1977, a fim de driblar pressões políticas e administrativas, a equipe se tornou empresa: Soul Grand Prix Produções, ampliando a gama de empreendimentos, como realização de shows e produção de programas de rádio, lançando vários discos. A equipe produziu e acompanhou o cantor Elton Douglas em 1976, realizando o primeiro baile da SGP na Zona Sul - junto com a equipe Black Power -, no Clube Mourisco, em Botafogo. Logo depois, Filó foi novamente convidado pela gravadora para uma nova empreitada, a criação da Banda Black Rio, cujos detalhes conheceremos mais à frente.

\section{Os DJs e as equipes de som}

Muitos dos seguidores dessas equipes pioneiras resolveram iniciar seus próprios negócios. Por volta de 1976, havia centenas de equipes de soul em 
atuação no Rio de Janeiro, e o movimento migrou para São Paulo, fazendo muito sucesso, e se espalhou por outras cidades, como Vitória, Porto Alegre, Belo Horizonte, Brasília e Salvador. O movimento Black Soul se disseminava pelo país através de suas filiais Black São Paulo, Black Porto, Black Bahia e Black Uai, mas o Rio continuava sendo o centro de "produção black", e os bailes cariocas recebiam caravanas de ônibus de várias cidades brasileiras. (PEREIRA, 2000, p. 2)

O centro e o subúrbio foram tomados pelos bailes de soul, com equipes profissionais especializadas, como a Black Power, Curtisom, Alma Negra, Célula Negra, Atabaque, Revolução da Mente, ${ }^{33}$ Dynamic Soul, Hollywood, Furacão 2000, que existe ainda hoje em outro formato, voltada para o funk carioca, ${ }^{34}$ além da equipe de Mr. Funky Santos, entre muitas outras. Para Thayer (2006, p. 90-91), a Zona Norte foi a região ideal para a difusão dos bailes black basicamente por ser um espaço de ocupação predominantemente negra aberta à difusão de sonoridades massivas afro-americanas. Além disso, era uma área que contava com vários clubes recreativos e esportivos, com amplos ginásios e salões de bailes e com as quadras escola de samba, ideais para eventos com grandes públicos, já que a média de frequência dos bailes girava em torno de 5 mil pessoas, podendo chegar a 10 ou 20 mil frequentadores. Espaços de lazer suburbano importantes como o Clube Mackenzie, Disco Voador, Portelão, Cine Show Madureira, Vera Cruz, Lespan promoviam bailes concorridos, que também eram realizados em regiões mais centrais, como Cesp-Rodoviária e na sede do cordão Bola Preta. Em entrevista a Essinger (2005, p. 25), o cantor Gerson King Combo comenta:

A Zona Sul era do Big Boy e do Ademir, a Zona Portuária e o Centro eram do Funky Santos, a Zona da Leopoldina, de Méier e Cascadura, da Soul Grand Prix. Mas de Madureira para lá - Oswaldo

33 Alusão ao título do álbum duplo homônimo de James Brown Revolution of the Mind: Recorded Live at the Apollo, v. 3, Polydor, 1971.

34 A equipe de som mais famosa até hoje foi a Furacão 2000. Criada em Petrópolis, tornou-se um miniconglomerado na área de entretenimento no Rio de Janeiro, depois de ter sido comprada por Rômulo Costa, um ex-funcionário da equipe. Atualmente, a Furacão é a maior marca ligada ao funk carioca, se desdobrando em gravadora e produtora, além de realizar programas de TV e de rádio. 
Cruz, Bento Ribeiro, Marechal Hermes, Rocha Miranda, era tudo da Black Power.

No auge do movimento, as equipes e produtores começaram a organizar shows com artistas de renome nacional e internacional. A profissionalização dessas equipes de som - que, em meados da década de 1970 giravam em torno de 300, como estimava Frias (1976, p. 4) - permitia que os produtores investissem intensamente em sonorização de qualidade e divulgação. Os maiores bailes, como os festivais de equipe, chegavam a obter rendas comparáveis a de um jogo no Maracanã, de acordo com Ademir Lemos: "Um negócio desses, só à base de discos, é uma loucura. De chegar a render Cr\$ 200 mil de bilheteria por baile com eu estou cansado de ver. Uma renda que um jogo, se não tiver Vasco ou Flamengo, não atinge”. (FRIAS, 1976, p. 3)

As equipes de som - também chamadas de equipes de baile - contavam com um DJ principal e outros secundários. Basicamente, havia um discotecário responsável por comandar os toca-discos, enquanto outro profissional controlava os amplificadores, e havia ainda um terceiro encarregado de "pilotar" a outra pick-up. As equipes podiam chegar a contar com dezenas de integrantes, dependendo do tamanho e importância do negócio.

\begin{abstract}
A equipe nada mais é do que a reunião de duas, três ou mais pessoas (quase sempre rapazes), que armam uma aparelhagem de som, compõem uma discoteca (só de soul no caso dos bailes black, onde não se aceita outro tipo de música), armam um esquema de iluminação tipo boate, com spots verdes, vermelhos, amarelos, roxos, azuis acendendo e apagando, variando as composições e os efeitos segundo a criatividade de cada equipe. Nas equipes menores, todo esse aparato cênico é confeccionado no fundo de quintais do subúrbio, à base de madeira compensada e papel de balão. (FRIAS, 1976, p. 4)
\end{abstract}

Além da produção do baile em si, as equipes realizavam o transporte e a instalação de seus sistemas de som, que se tornavam cada vez maiores e mais potentes, e preparavam a iluminação e a decoração do salão. Segundo Essinger (2005, p. 27), o DJ Marcão, da equipe Cash Box, uma das maiores da época, fazia seus bailes com um equipamento especial, com caixas de som 
pequenas e potentes que facilitavam o transporte e transmitiam o som de um gravador e de fitas cassetes, dispensando a utilização de vinis. O pai e o tio, técnicos em eletrônica, montaram amplificadores com peças importadas, e Marcão foi o primeiro disc-jóquei a discotecar em um som estéreo (HUMBERTO DJ, 2011), chegando a montar inúmeros amplificadores através de kits importados. Os DJs eram responsáveis por escolher e tocar o set list do baile, mas também atuavam como animadores, realizando sorteios e concursos, criando diferentes climas para os diversos momentos do baile. Como mestres de cerimônia, muitos DJs ultrapassavam o papel de enterteiners e proferiam discursos inflamados e politizados em torno da conscientização racial. Em outras esquipes, os DJs faziam a animação, realizando sorteios de discos e ingressos, camisas, boinas e sapatos, premiações em dinheiro para melhores dançarinos e concursos de beleza. Havia premiações para melhores dançarinos e concursos de beleza específicos, que celebravam tanto uma estética afro-brasileira, quanto um estilo baseado em um visual inspirado em celebridades afro-americanas. Essas eram estratégias que buscavam uma conscientização racial a partir de uma valorização estética e uma celebração de um estilo visual, mas também performático, em detrimento de uma atuação político-pedagógica mais convencional.

A atmosfera das festas soul é sempre vertiginosa e feérica: lanternas estroboscópicas decompõem gestos e parecem eliminar a gravidade; projetores vermelhos varrem um mar de cabeleiras afro que se agitam compassadamente; uma grande esfera de espelhos facetados, suspensa no teto do galpão, espalha um faiscamento constante. (BLACK RIO, 1976, p. 154)

Cada vez mais profissionalizados, os donos de equipe eram os contratantes dos DJs, técnicos de som e dançarinos e detinham os direitos fonográficos de alguns dos sucessos que tocavam em seus bailes, posteriormente lançados em coletâneas em vinil. Apesar de muitos DJs serem famosos, a maioria ainda era funcionária das equipes: "O DJ tocava virado de costas para a plateia, para que todo mundo pudesse ver da pista de dança o equipamento piscando”. (VIANNA, 1988) Ou seja, a equipe era a estrela maior do baile. 
O DJ sempre foi importante no Black Rio, mas é verdade que sempre foi muito mal pago, explorado mesmo. Enquanto os donos das equipes enriqueciam, iam pagando miséria aos discotecários. E o mais chato era que o nome do DJ nunca aparecia muito. ${ }^{35}$ (ASSEF, 2003, p. 46)

Aos poucos, alguns DJs começaram a desenvolver performances diferentes, como os da Cash Box, que "se colocavam à frente do palco e da aparelhagem, tocando, dançando e animando o público, exibindo uniformes com a marca da equipe”. (ASSEF, 2003, p. 46) Por vezes, DJs montavam suas próprias equipes e faziam sucesso, chegando inclusive a apresentar programas de rádio e televisão. Monsieur Limá, discotecário e empresário de bailes, teve um programa de televisão aos sábados, inspirado no programa americano Soul Train, ${ }^{36}$ divulgando as novidades do soul e apresentando grupos de dançarinos.

Mr. Funky Santos também teve uma intensa atuação no mercado carioca da black music. Comandou programas em emissoras de rádio importantes, como Imprensa FM, Roquete Pinto, Tropical e Manchete FM. E com sua foto nas capas, lançou, até os anos 1980, uma série de cinco coletâneas em vinil dos hits de soul e funk que faziam sucesso em seus bailes. Na Top Tape, uma das mais importantes gravadoras cariocas nos anos 1970 e 1980, foi responsável pela produção de dezenas de álbuns de outras equipes de som, como Black Power e Cash Box. Santos se afastou da cena após seu filho ter sido assassinado na porta de um baile funk no Rio e passou a atuar como corretor de imóveis até vir a falecer com um câncer no estômago em 2012.

Ademir Lemos também investia na área de produção fonográfica, um negócio até mais lucrativo que os bailes. Restrições de importação limitavam severamente chegada ao mercado de discos brasileiro de selos norte-americanos independentes como Motown e Stax. Isso favorecia as multinacionais com afiliadas brasileiras, como a Columbia Broadcasting System (CBS) e a Philips, dona da Polygram. Essa vantagem permitia que as multinacionais,

35 Depoimento de Mr. Funky Santos.

36 Soul Train foi um musical televisivo diário americano fundamental para a história black music que começou a ser exibido em 1971 e durou até 2006, voltado para apresentação de shows e números de dança. 
ao lado de selos brasileiros regionais, adquirissem os direitos para distribuir singles americanos independentes no Brasil e também lançar coletâneas localmente. Lemos, assim, conseguiu negociar as marcas das mais importantes equipes de soul para as companhias de disco, que davam nome a coletâneas de sucesso, com as músicas mais tocadas nos seus bailes. E o público dos bailes de soul era um mercado garantido para esses álbuns, divulgados também por meio de estratégias de marketing preliminares, como concursos e sorteios. Assim, produziu o primeiro disco da equipe SGP, lançado pela Top Tape em 1974, que obteve grande êxito. Em meio a esse sucesso comercial, Lemos rapidamente adotou a retórica do soul, com o discurso menos militante do "negro é lindo", tradução de "Black is beautiful", lema estadunidense que não denominava uma organização específica, mas foi apropriado por diversos movimentos civis e negros e tinha relação com a propagação do amor próprio e da autoafirmação, exigindo respeito e difundindo a valorização de novos padrões estéticos de beleza negra, mas também se relacionava a noções de boa aparência, moralidade e bom comportamento. Outros DJs que conseguiram fazer sucesso para além de suas equipes foram Mister Paulão Black Power, Luizinho Disc-jóquei Soul e DJ Samuel, conquistando seguidores assíduos e deixando suas marcas na cena black carioca. ${ }^{37}$

Mesmo com essa popularidade inicial, ainda havia muita dificuldade para encontrar nas prateleiras das lojas os sucessos internacionais do soul. Esses LPs específicos eram extremamente raros e importados, e poucas lojas trabalhavam com esse segmento. Normalmente, um lançamento estrangeiro demorava de dois a três meses para chegar ao Brasil, quando chegavam, "[...] tanto que os discotecários cariocas continuavam a chamar aquela música soul, quando funk era a palavra usada nos EUA”. (VIANNA, 1987, p. 53) A solução encontrada por muitos DJs foi contar com encomendas feitas a amigos, comissários e aeromoças que viajavam para os EUA e tinham condições

37 "Houve um tempo em que o discotecário era uma figura apagada no jogo de luzes, som e alegria da pista de dança. Era o maestro sem batuta, escondido entre pilhas de discos, às vezes jogado num canto qualquer, atrás de pratos, copos e panelas, ao lado da copa ou do bar de uma boate. Agora o cenário é outro... De repente, aquele modesto canto passou a ficar pequeno demais para a importância dos DJs das mil e uma noites de som...". Mário Henrique Peixinho, programador da rádio Mundial, na contracapa do LP DJs 77. (RCA Victor, 1977, encarte de um disco). 
de trazer os últimos lançamentos (VIANNA, 1987, p. 53), especialmente "porque nas lojas, os profissionais de mais nome ou com melhores relacionamentos tinham prioridade nos lançamentos”, de acordo com Essinger (2005, p. 34). A oferta de novidades era escassa, especialmente porque o número de equipes foi aumentando, mas com a maior profissionalização e o aumento dos lucros, muitos DJs passaram também a viajar para os EUA a fim de adquirir novidades, indo especialmente para Nova York e Miami - às vezes, viajando e retornando no mesmo dia. No Brasil, os vinis custavam caro, tanto os vendidos nos balcões das lojas quanto os encontrados no câmbio negro: "um compacto importado e raro chegando a custar de Cr\$ 2 mil a Cr\$ 3 mil, os menos raros a Cr\$ 500, no mínimo”. (FRIAS, 1976, p. 4) Às equipes e aos disc-jóqueis com menor verba, restava a saída de realizar as "transações de discos” (VIANNA, 1987, p. 53), em que equipes e discotecários trocavam e vendiam discos entre si.

Os DJs tinham preferência pelos Disco Mix, que eram discos, a maioria de 12 polegadas (LP) [...], com várias versões de uma ou algumas músicas remixadas, de forma que ficassem levemente modificadas da versão original (algumas vezes apenas com sua duração alongada), o que conferia a marca da exclusividade àquele DJ e sua equipe de som que conseguiu tal raridade. Mas as raridades também poderiam vir por meio de compactos importados de 7 polegadas, que tocavam a velocidade de 45 rotações por minuto $(\mathrm{rpm})[\ldots]$, conhecidos como compactos de Funk Forty Five. (BRAGA, 2015, p. 62)

As equipes competiam para conseguir mais novidades e alguns DJs retiravam o rótulo do disco para evitar que possíveis concorrentes descobrissem os nomes dos artistas e das faixas, tornando-as "exclusivas" ou fazendo uso de recursos mais escusos, como trocar o nome de uma música de sucesso por outro título, ocultando o nome do artista ou disponibilizando informações falsas. (VIANNA, 1987, p. 53) Um dos donos da equipe Curtisom, Reginaldo, conta ainda que importadores de discos clandestinos muitas vezes traziam poucas cópias do mesmo vinil e as vendiam já sem capa e com selos adulterados. Se algum DJ ou dono de equipe quisesse ter uma determinada canção, deveria, pois, entrar em contato com o próprio comerciante que 
trazia as encomendas, pois apenas o vendedor detinha as informações sobre o nome da música e sobre o artista solicitado, mantendo-as em segredo. (GIRALDO, 2014, p. 26) O DJ Marlboro, um dos maiores expoentes da cena funk carioca, conta em depoimento a Pedro Schprejer:

A gente ia para o baile para escutar músicas que não ouvia em lugar nenhum. Algumas delas, quando tocavam, o público urrava. Não tinha internet, era muito difícil conseguir disco importado. Algumas músicas eram preciosidades. Vi um cara trocar um fusca por um compacto importado - não estou brincando. (SCHPREJER, 2009)

É neste momento que se consolida a importância do trabalho dos DJs e dos bailes como agentes e espaços de intermediação entre gêneros musicais e fãs e consumidores. Em muitos casos - e no universo da black music em geral-, o papel dos DJs tem extremo valor no processo de criação e consolidação dos gêneros, pois suas ações, historicamente, têm sido mais eficientes do que a de jornalistas e críticos, a partir da descoberta de novos mercados e da colocação em prática de novidades apreendidas nas experiências das pistas de dança. (FRITH, 1996, p. 88) Em uma era pré-internet, em que aparelhos de TV, vitrolas e discos ainda eram itens de "luxo" para uma população desfavorecida economicamente, o rádio e os bailes, através do trabalho de disc-jóqueis e produtores, funcionavam como "filtros", facilitando o acesso a uma cultura internacional. "Nos bailes era onde se ouviam as novidades. Ali, todos perceberam que o futuro poderia ser mais dançante". ${ }^{38}$ (ASSEF, 2003, p. 47) Como ainda não havia gravadoras promovendo fortemente esses nomes da black music no Brasil, o DJ assumia o papel de "garimpeiro", descobrindo novidades, raridades e se destacando perante seus pares. Muitos discotecários se tornavam famosos, inclusive, por serem os únicos a possuir um determinado disco, atraindo pessoas para seus bailes, pois era apenas neles em que se poderia ouvir uma música específica. (ASSEF, 2003, p. 26) Ao mesmo tempo, os DJs assumiam e propagavam ideais de carisma e juventude, e suas atividades eram associadas ao novo por serem retransmissoras e difusoras

38 Depoimento do DJ Corello publicado no livro Todo DJ já sambou: a história do disc-jóquei no Brasil, de Assef (2003). 
das novidades de uma cultura global, atualizando suas ações mediadoras e atores políticos. A demonstração de suas capacidades de atração e prestígio garantia uma visibilidade e um certo poder de condução das massas, a partir da atribuição para si de um possível caráter “divino” de líder, que remeteria a um tipo ideal de autoridade ideológica (BARRETO, 2007), o que era realçado pela exibição de imagens, discursos e valores compartilhados nos bailes.

Bairros da Zona Norte - como Colégio, Irajá, Marechal Hermes, Rocha Miranda, Nilópolis, Acari, Andaraí, Bangu, Catumbi, Coelho da Rocha, Duque de Caxias, Grajaú, Leopoldina, Madureira, Méier, Mesquita, Nilópolis, Parada de Lucas, Pavuna, Penha, Ramos, Tijuca, Vila da Penha e Vilar dos Telles e Pavuna - passaram a compor uma cena musical pautada pela black music, que se estendeu até a Zona Oeste, mais distante do centro da cidade. A economia do Rio de Janeiro se baseava em uma forte estrutura terciária, o que incentivava a priorização de investimentos urbanísticos pela administração pública. (MOTTA, 2000, p. 85) Muitos centros comerciais populares e "calçadões” foram construídos e se converteram em áreas de intenso trânsito de pessoas. Importantes polos comerciais e urbanos do subúrbio, como Madureira, Caxias, na Praça do Relógio, ${ }^{39}$ Vilar do Teles ou na Rua Sete de Setembro, no Centro do Rio (FRIAS, 1976, p. 3), se tornaram pontos de encontro e de decisão dos blacks e locais preferenciais de divulgação dos bailes por meio de cartazes, faixas pintadas à mão, ${ }^{40}$ colocadas em avenidas de intenso movimento e distribuição de panfletos. "Depois alguns muros da cidade passaram a funcionar como quadros de aviso, agora menos usados porque baixou a fiscalização multando as equipes anunciadas”. (FRIAS, 1976, p. 4)

39 O DJ Paulinho, da equipe Black Power, se lembra dessas movimentações: “sempre todos os sábados, reunião dos Black's para discutir sobre músicas, discotecários, equipes que melhor se apresentavam etc... Detalhe: Essas reuniões rolavam e os participantes sempre se vestiam no maior estilo Black, usando chapéu, óculos escuros, bengalas, blazer, sapatos com dois e três andares. A Praça de Duque de Caxias ficava repleta de gente e parecia até que você estava no Harlem!?”. Disponível em: <http://zinezerozero.blogspot.com.br/2011/03/bgirlz-2011.html>. Acesso em: 6 abr. 2016.

40 A urbanização promovida por Chagas Freitas, governador do estado da Guanabara (1971-1975) e do Rio de Janeiro (1979-1983), levou à criação de grandes espaços chamados calçadões ou ruas de pedestres, às quais era vedado o trânsito. Os calçadões eram exclusivamente voltados para o comércio, mas com espaço para canteiros, árvores, bancos de praça, favorecendo a circulação de pessoas, como um shopping a céu aberto. 
Silva (2013, p. 139) lembra que os flyers fizeram parte da cultura da música negra norte-americana, especialmente no universo hip hop, relembrando que as filipetas foram criadas no século XII, mas foram popularizadas com o advento da fotocópia, já nos anos 1960, o que barateou a reprodução de panfletos, facilitando a sua produção em qualquer espaço e em maior escala. No Brasil, as primeiras filipetas de divulgação dos bailes soul eram simples, datilografadas e recortadas à mão. À medida que os bailes cresciam, as equipes criavam panfletos mais elaborados, utilizando cores, slogans criativos, designs mais modernos e diferentes elementos gráficos que chamavam a atenção dos frequentadores e reproduziam marcas estéticas da época, transformando os panfletos em uma espécie de documento da história da cena black. Os também chamados volantes eram distribuídos duas ou três semanas antes dos bailes e anunciavam as atrações das noites, as equipes e artistas participantes, os concursos e premiações e ainda davam informações sobre as conduções que poderiam ser utilizadas para se chegar ao local do baile. Não era raro um volante anunciar mais de uma festa, em que diferentes equipes dividiam os custos de produção, impressão e distribuição dos panfletos. Frias (1976, p. 4) transcreve o texto de um dos volantes coletados:

Grêmio de Rocha Miranda, Av. dos Italianos, 282 apresenta a maior festa da cidade. O $3^{\circ}$. Aniversário da Horus. Dia 17 de junho, Sábado, 19 horas. Horus, o aniversariante somos nós e o presenteado é você. Conduções: 960 - Penha - N. Iguaçu - B. Roxo - Méier - V. Nova - Cascadura - Jardim Botânico - Cascadura - Vilar dos Teles. Com este entrada grátis. Ou Vitória T. C. Rua Porto Alegre. Hulk apresenta Os Gigantes do soul Messiê Limá. Filme de Wattstax. Santos. E dançando a vedete Cia Soul. Atenção: Hulk oferece ao melhor dançarino Cr\$ 500,00.

Ou ainda: "Atenção: William Hulk oferece um sapatão ao melhor dançarino”. Mensagens positivas de paz e incentivo também eram transmitidas pelos panfletos e convites, como "o bom andamento do baile depende exclusivamente de você” (BLACK RIO..., 1978, p. 154), demonstrando um desejo dos organizadores de garantir a paz e a ordem em suas festas. 
A expansão do público do soul na segunda metade dos anos 1970 possibilitou aos produtores dos bailes o aluguel de grandes espaços, como clubes maiores e quadras de escolas de samba. Segundo Frias, na escola Império Serrano, por exemplo, os bailes já estavam praticamente incorporados ao calendário de eventos da agremiação. ${ }^{41}$ Os clubes e escolas podiam ficar com $20 \%$ a $50 \%$ da bilheteria arrecadada, e muitos firmavam contratos com as equipes, garantindo a realização semanal de bailes. "A Black Power tem Contrato com o Boêmios de Irajá, para onde carrega, no mínimo, 3 mil pessoas cada sábado. A Soul Grand Prix com o Maxwell, cuja lotação se completa a cada domingo". (FRIAS, 1976, p. 5)

Com o aumento da lucratividade, foi possível às equipes o pagamento de anúncios em rádios populares, como a Mundial, e em jornais, como os tijolinhos do Jornal do Brasil. "Big Boy e a Rádio Mundial também sempre foram divulgadores dos bailes soul, cada chamada custando, hoje em dia, nunca menos de Cr\$ 300 ou Cr\$ 500. E cada equipe usando de cinco a dez chamadas por dia” (FRIAS, 1976, p. 5), o que não substituía a divulgação barata por meio do anúncio dos próximos bailes realizados pelos próprios discotecários no final de cada noite. Com o aumento do lucro, as equipes podiam comprar espaço nos jornais para divulgar os bailes. As equipes diversificavam suas atividades, e até bailes infantis de soul eram realizados.

Em meados da década, começaram a ser organizados os festivais de equipes. Assim, em um dia, sete equipes podiam tocar em um mesmo baile. $\mathrm{O}$ Primeiro Encontro dos Blacks da Guanabara foi realizado no Greip da Penha em 1977 e reuniu quase 15 mil pessoas em um lugar onde só cabiam, no máximo, 5 mil. O evento, realizado pela SGP e pela equipe Black Power, contou ainda com o show da banda Watergate Tape, formada por músicos americanos que moravam no Rio. Esses festivais, geralmente, começavam no final da tarde e iam até a madrugada do dia seguinte, com várias equipes se sucedendo ao longo do evento. Cada equipe ocupava um lugar no salão para montar

41 Para Hanchard (2001, p. 140), a escolha das quadras de escolas de samba para a realização de bailes cada vez maiores era devido ao alto valor do aluguel de salões sociais, bem como à "relutância de muitos proprietários brancos em permitir que grandes levas de brasileiros negros entrassem em seus prédios". 
as caixas de som. Na sucessão das apresentações, enquanto uma equipe tocava, as outras aguardavam sua vez, em silêncio e com as luzes apagadas. Os fãs de cada equipe iam se reunindo proximamente às equipes de preferência, dividindo a pista em territórios.

Outro evento grandioso foi o lançamento do disco da SGP ${ }^{42}$ em 1976, no Guadalupe Country Clube, que contou também com aproximadamente 15 mil pessoas. "A piscina do clube estava vazia e as pessoas dançavam dentro dela. A passarela em frente ao Guadalupe estava tomada", narra o Nirto, um dos donos da SGP, para Essinger (2005, p. 29). Não só a piscina e a passarela, mas a multidão fechava a própria Avenida Brasil. Contudo, o baile teve que ser interrompido mais cedo, por conta da presença da Polícia Militar (PM), que enviou para o local mais de 600 homens da tropa de choque da aeronáutica, segundo Dom Filó em depoimento a Essinger (2005, p. 29). Um massacre eminente foi evitado pelo DJ, que solicitou que acendessem as luzes do salão, desligou a música e acalmou o público, terminando o baile:

Peguei o microfone e agradeci a presença do coronel, dizendo que ele estava ali para garantir a ordem. Foi tudo o que pude fazer. Ele falou que eu tinha resolvido um problemão e que a ordem era baixar o cacete. Puseram um campus em mim e fui levado para interrogatório. (DOM FILÓ, 2000, p. 1)

A polícia acompanhava de perto a movimentação dos bailes, e, em muitos registros da época, é possível encontrar informações preciosas sobre os fatos. Em relação ao baile do Guadalupe, o pedido de reforço policial foi feito pela direção do clube. Mas não por temor de atos de violência, e sim por conta do receio em relação ao excesso de lotação. Nos registros, havia ainda referências a uma possível proibição de que a SGP tocasse no Grêmio Recreativo

42 "The Beautiful Black People estaria no maior sufoco, não fosse o surgimento das equipes de som. There was a time em que foi um só Baile da Pesada. Hoje desdobraram-se em centenas de Disco Dance instalados nas festivas domingueiras de clubes. A Equipe Soul Grand Prix conquistou, através de suas multimilionárias performances, o direito de registrar esse acontecimento tão marcante". (Texto de encarte do LP da SGP escrito por Ademir Lemos, produtor do disco, Top Tape, 1976) 
de Rocha Miranda, pois a equipe já vinha sendo investigada pelo Departamento da Ordem Política e Social (Dops) por prática e incentivo de discriminação racial, segundo consta no pedido de busca do Departamento Geral de Investigações Especiais (DGIE) emitido pela Secretaria Geral do Conselho de Segurança Nacional, $n^{\circ}$ 02343, de 2 de julho de 1976, de acordo com Pires (2015, p. 42).

Os relatórios da polícia da ditadura, de fato, observavam um clima de tranquilidade nos bailes, e as investigações se referiam mais às tentativas de descobrir possíveis organizações radicais de fundo racial. Mesmo assim, era comum haver repressão a vários bailes, em que discos eram apreendidos e DJs eram levados para depor, como ocorreu festa de lançamento do primeiro disco de Gerson King Combo, em 1976, no Olaria Sport Club, que havia reunido 30 mil pessoas. Muitos disc-jóqueis, evitando perder valiosos discos importados de soul, colocavam-nos em meio a vários discos de samba, que eram entregues à polícia na hora das batidas e apreensões. Eventualmente, até o som da discotecagem era substituído quando havia notícias de que a PM estaria chegando, e o soul era substituído por discos de samba, modificando a trilha sonora dos bailes para eliminar suspeitas e evitar a violência policial. Depois que a polícia ia embora, o soul voltava a tocar.

Frias (1976, p. 4) reproduziu a indignação de um entrevistado: "por que é que preto não pode fazer festa que baixa logo os cana?”. Durante a Terceira Caravana Soul, realizada em junho de 1976 na quadra da escola de samba Império Serrano, em Madureira, foi exibido pela primeira vez o documentário Wattstax no Brasil. Durante o festival, policiais infiltrados entre os participantes do baile relataram detalhes da exibição, que não sofreu nenhuma forma de repressão por parte da polícia. E, segundo o relatório policial consultado por Alberto (2009, p. 15), o filme não foi exibido na íntegra, e apenas algumas cenas foram mostradas, sem áudio. Para o serviço secreto da polícia, isso não representou maiores problemas políticos, já que, sem o áudio, possíveis discursos "demagógicos" subversivos não seriam transmitidos para o público, desconsiderando qualquer perigo na exibição apenas das imagens em movimento. Alberto (2009) lembra que, naquele tempo, a censura do governo militar havia proibido a exibição de filmes nos cinemas, 
particularmente americanos, que tivessem uma temática explicitamente racial, a fim de evitar que os negros brasileiros fossem influenciados pelos movimentos afro-americanos.

O fato de a polícia secreta descartar o potencial político de Wattstax em razão da ausência de som sugere suas habilidades limitadas, naquele momento das investigações, para perceber o poder das imagens visuais para inspirar e comunicar novos tipos de identidades raciais e políticas. Wattstax - com suas cenas vibrantes de quase cem mil negros americanos ostentando cabelos afros, dashikis e diferentes estilos soul e funk, e enchendo o LA Coliseum em um evento voltado majoritariamente para a comunidade negra, durante o qual Jesse Jackson conduziu o público (com os punhos erguidos) em uma excitante versão de seu poema 'Eu sou alguém' (e suas palavras piscando por todo o estádio), e o National Black Anthem - comunica uma afirmação da negritude e orgulho racial para os quais nenhuma trilha sonora ou discurso político teria sido necessário. (ALBERTO, 2009, p. 15)

Já com o som, o filme pareceu ter um efeito mais intenso. Em julho de 1976, o recém-criado IPCN resolveu realizar, em comemoração ao primeiro aniversário da organização, uma exibição com áudio de Wattstax. Mas não em nenhum clube suburbano ou durante algum baile. O local escolhido foi o Museu de Arte Moderna (MAM) do Rio de Janeiro, no bairro do Flamengo, Zona Sul da cidade, uma instituição de prestígio para a elite e também para os movimentos contraculturais da época. Esse ato concedeu uma importância simbólica ao evento, organizado por uma militância negra e voltado para uma audiência também negra em um espaço percebido como branco e ocupado por uma elite intelectual. Lena Frias (1976) descreve o episódio como um momento de comoção pública, em que alguns indivíduos da plateia seguiam as frases de Jesse Jackson com os pulsos levantados, emocionados. Sobre a dimensão de Wattstax e sua importância para o movimento black, a jornalista comenta que o filme funcionava uma "espécie de modelo e, como tal, exaustivamente visto e estudado": "Passou a constituir-se num sensibilizador permanente, atuante e eficaz. As frases de Wattstax são decoradas, 
repetidas, bordadas nas roupas, cantadas, cantaroladas, dançadas, assoviadas”. (FRIAS, 1976, p. 4)

\begin{abstract}
Aberta a bilheteria, rapidamente os 220 lugares ficam ocupados e, poucos minutos após, quase 320 pessoas comprimem-se na sala da Cinemateca. Lá embaixo, no pátio outros tantos tentam entrar. [...] O público negro (havia dois brancos presentes, os habitués do museu ficaram lá embaixo), não presta muita atenção às palavras, mas passa a gritar e aplaudir logo que começa a projeção [...]. O público repete as palavras, as frases, embora o sentido lhes possa até ser desconhecido. E quando o Reverendo Jesse Jackson aparece na tela conclamando os negros americanos à profissão de fé na própria raça, no cinema, a exemplo do que sempre acontece em todas as exibições de Wattstax em todo o Grande Rio, repete com eles as palavras que fazem chorar um jovem negro de 16 anos, Roberto, estafeta, que está ao meu lado, espremido no corredor da cinemateca 'I am somebody'. Jessie Jackson fala na tela, com o punho erguido braço dobrado para dentro, a multidão no estádio de Los Angeles repete gesto e palavras. Na pequena multidão reunida no MAM, como nas grandes multidões reunidas nos ginásios da Zona Norte e Baixada, alguns punhos também repetem o movimento, e todo mundo dizia em coro, uns mais altos outros quase sussurrando: 'I am somebody'. ${ }^{43}$ (FRIAS, 1976, p. 4)
\end{abstract}

O soul chegava de vez à Zona Sul e, em 1976, foi organizada a primeira festa soul por uma equipe de som do subúrbio no Clube Mourisco, em Botafogo. O baile realizado em 31 de julho, sábado, foi divulgado em volantes que exibiam o título "Soul invade a Zona Sul” e contou com a presença de 9 mil pessoas, segundo cobertura do Jornal do Brasil. (O SOUL..., 1976, p. 5) O público dançou de oito da noite às cinco da manhã, animado pela SGP, promotora do evento, e pela equipe Black Power, além da animação do discotecário Monsieur Limá, que lançava sua equipe de som, a Soul Discotheque,

43 Wattstax também foi exibido na sede da Associação Brasileira de Imprensa (ABI) em 6 de setembro de 1977, em um seminário intitulado "O soul - e suas implicações sócio-econômicas e culturais na comunidade", com a participação do crítico musical Roberto Moura e da militante negra e antropóloga Lélia Gonzales. 
que, como o nome apontava, era especializada em música disco e passou a disputar com as equipes de soul a preferência do público. O próprio Monsieur Limá passou, posteriormente, a contratar equipes de soul e a produzir bailes na Zona Sul, ganhando muito dinheiro. (HANCHARD, 2001, p. 140) O baile do Mourisco serviu como marco da onda soul pela cidade, atingindo diferentes grupos sociais.

Apesar de representarem uma importante plataforma de divulgação de artistas nacionais, era majoritariamente a música norte-americana que abastecia os bailes. O inglês não era dominado pela grande maioria dos fãs e participantes da cena, mas isso não impedia o consumo dessas canções, já que o gosto pelo ritmo, a sonoridade e a pulsação do soul ultrapassavam fronteiras idiomáticas. E o consumo de produtos americanos também acentuava um desejo e uma demanda por ingressar em uma modernidade idealizada por parte desses jovens, que não mais se identificavam com produtos culturais tradicionais, como o samba e outros gêneros populares brasileiros. Foi naquela época que surgiram as primeiras "melôs", como adaptações de expressões em português, divertidas, que se assemelhavam e aproximavam à pronúncia de fraseados em inglês. "Então o sujeito ouvia 'Hard Work', do John Handy, e saía cantando 'Morre o Boi'. Dali a cinco minutos, tinha 2 mil pessoas no baile cantando 'Morre o Boi”', lembra o produtor de rap Fábio Macari em depoimento a Assef (2003, p. 26).

Um grande chamariz para o público e uma forma eficaz de manter o entusiasmo ao longo dos bailes - que tinham, em média, duração de seis horas - foi a incorporação de performances ao vivo, e as equipes passaram a organizar grandes shows, que deram um especial incentivo aos cantores de soul brasileiro. Tim Maia, Jorge Ben Jor, Cassiano, Gerson King Combo, Tony Tornado compunham um panteão para o soul brasileiro diante de uma audiência massiva. O primeiro disco de King Combo (Gerson King Combo, Polydor, 1977), inclusive, foi lançado em um grande baile no Portelão, em Madureira, durante um encontro das equipes de soul Black Power, SGP e Uma Mente Numa Boa, em 1977. A preocupação com a questão racial não era uma unanimidade, mas alguns DJs ganharam fama justamente por articular lazer e política de forma inovadora. No Rio, as equipes se diferenciavam por suas ações e estratégias específicas, denotando diferentes motivações. 
Muitos DJs buscavam apenas entreter suas audiências, animando seus bailes ao som do soul, em oposição àqueles que levantavam a bandeira do orgulho negro mais seriamente.

Os bailes - que, a princípio, eram uma opção mais barata e acessível para populações de menor renda - passaram a aumentar o valor da entrada, diante do aumento dos custos para produção, compra de equipamentos, pagamento de funcionários e aluguel de espaços maiores, inclusive em clubes mais elitizados, como o Tijuca Tênis Clube ou clubes na Zona Sul. Em Cavalcanti (1981, p. 8), um entrevistado que costumava frequentar as festas black na época declarou: "Coisa de louco, pagar cem cruzeiros num baile de 'soul', porque ele é coisa nossa e os donos das equipes que organizam os bailes estão ficando ricos à nossa custa”. Há um conflito de valores, pois, de acordo com informação de Bahiana (2006, p. 304), os valores praticados para a entrada nos bailes giravam em torno de cinco a oito cruzeiros. Era comum que mulheres não pagassem a entrada, mesmo que os ingressos tivessem valor acessível. Também segundo Frias (1976), as entradas poderiam custar entre sete e oito cruzeiros, e a Veja (BLACK RIO, 1978, p. 154) contabilizou ingressos que oscilavam “entre 8 e 25 cruzeiros (damas grátis)". Independente do valor da entrada, o fato é que os bailes reuniam multidões, e os donos das equipes faturavam alto, o que era motivo de crítica, pois apontava para uma suposta falta de comprometimento com a população negra e suburbana e com demandas específicas desse grupo, como opina um jovem negro frequentador dos bailes: "Vários promotores de baile enriquecem em cima de nós [sic] para depois irem gastar em 'discotheque' de brancos”. (CAVALCANTI, 1981, p. 8-9) E Bahiana (2006, p. 304) acrescenta: "Um fim de semana rendia, em média, Cr\$ 200 mil para essas equipes nas quais, via de regra, os discotecários - senhores supremos do repertório - eram brancos".

A imprensa carioca, percebendo o efervescente movimento que mobilizava milhares pessoas, batizou o fenômeno de Black Rio. A proliferação desses bailes black chegou a outras cidades do Brasil, como São Paulo, Salvador, Belo Horizonte, representando uma criação conjunta de símbolos étnicos e partilhas de experiências socioculturais. Segundo Bahiana (2006), na época, as festas no subúrbio e na Zona Sul foram responsáveis pelo enorme índice de venda de discos de black music, superando, inclusive, o rock dos Rolling 
Stones ou do Led Zeppelin. ${ }^{44}$ Os frequentadores dessas festas eram vistos como um enorme mercado em potencial. Inicialmente, foram lançadas coletâneas com os principais sucessos dos bailes. Muitas delas eram assinadas pelas equipes de som e pelos DJs de maior prestígio, em pequenas gravadoras. A gravadora repassava uma parte das vendagens para as equipes, que se tornaram cada vez maiores e mais rentáveis. As majors do disco, estações de rádio e emissoras de TV ficaram ansiosas para lucrar com o potencial comercial do movimento Black Rio e tentaram garantir um lugar para o segmento da soul music no mercado musical nacional.

Como consequência dessa circulação, pode-se dizer que houve uma institucionalização do soul como um segmento estável dentro do mercado musical brasileiro até aquele momento. Não só pela atividade dos próprios artistas que atuavam no interior do gênero musical, como também pelos que praticavam mesclas com outros gêneros, propondo, inclusive, novas reconfigurações para o próprio samba, matriz musical nacional. Apesar de estratégias mercadológicas diferenciadas, o mercado fonográfico, junto a artistas e produtores, tentava articular uma forma de introduzir no Brasil a produção musical negra de sucesso produzida nos EUA, ao mesmo tempo em que se voltava para o incentivo da produção de músicos locais do gênero. Era uma maneira de explorar um mercado paralelo que se desenvolvia a partir da cena musical dos bailes black e de incorporar, na produção musical brasileira, matrizes e dicções internacionais, notadamente norte-americanas, que tinham a ver, necessariamente, com novas formas de comunicação e expressão, representando também estilos de vida e estratégias de sobrevivência e negociação simbólica.

44 De fato, apesar da importância no cenário mundial e de influenciar a música popular brasileira profundamente, o rock, durante os anos 1970 no Brasil, não alcançava grandes índices de vendagem, "com um consumo numericamente baixo (os grande vendedores estrangeiros do gênero, como as grupos Rolling Stones e Led Zeppelin, atingiram, no Brasil, marcas medíocres de vendagem, entre as 10 e as 30 mil cópias, no máximo, com uma saída média, mensal, entre 2 e 5 mil unidades vendidas)". (BAHIANA, 1980, p. 41) 


\section{A indústria fonográfica no Brasil dos anos 1970}

A década de 1970 pode ser considerada como um período de grande crescimento do mercado fonográfico brasileiro, que foi acompanhado pela reestruturação desse setor produtivo por conta de grandes investimentos de capitais nacionais e estrangeiros, que acompanhavam o rápido desenvolvimento das tecnologias de gravação e produção e a utilização de novos modelos de gerenciamento no interior das gravadoras. (MORELLI, 2009, p. 15) Os anos 1970 também podem ser definidos pela consolidação do mercado de bens culturais, ainda que sob a tutela de uma ditadura militar de cunho conservador e autoritário, que dava contornos a um projeto de "integração nacional" mediado pelo capital privado, gerando uma enorme expansão na produção, distribuição e no consumo da cultura. Desse modo, a integração da nação se dava por meio do consumo de bens culturais, interligando consumidores e cidadãos na construção de uma cultura em que o popular se confundia com o massivo e com o mercado.

Era um momento de expansão econômica que motivou, especialmente de 1965 a 1972, o crescimento de $400 \%$ do mercado nacional de discos (MORELLI, 2009, p. 87), cenário refletido diretamente em números: de 5,5 milhões de discos em 1966, passaram a ser vendidos 52,6 milhões em 1979. (VICENTE, 2008, p. 105) E de 1978 para 1979, o Brasil se tornou o sexto maior consumidor de discos do mundo (MORELLI, 2009, p. 96), colocando o país em uma posição bastante estratégica como um alvo importante dentro do mercado mundial. Diversas as filiais internacionais ampliaram suas atividades no país nesse momento:

- a Philips/Phonogram - depois PolyGram e, atualmente, parte da Universal Music - chegou ao Brasil a partir da aquisição da Companhia Brasileira do Disco (CBD) em 1960;

- a CBS - hoje, Sony Music-, já em atividade no Brasil desde 1953, garantiu boa fatia do mercado com o sucesso da Jovem Guarda;

- a Electric and Musical Industries Ltd (EMI), que chegou ao Brasil em 1969 por meio da aquisição da Odeon;

- a Warner, cuja subsidiária brasileira chegou aqui em 1976; 
- a Ariola, que integrava o conglomerado alemão Bertellsman (BMG) e chegou ao Brasil em 1979;

- a Radio Corporation of America (RCA), que operava aqui desde os anos 1920 e, mais tarde, também foi comprada pela Bertellsman, tornou-se o núcleo da BMG.

Além das internacionais, havia gravadoras menores nacionais, como a Copacabana, Continental, RGE-Fermata, Top Tape e Tapecar. Em 1971, surgiu a Som Livre, braço fonográfico da Rede Globo, criada para lançar LPs de trilhas de novelas. Outras gravadoras vinculadas a emissoras de TV também foram criadas, como a GTA (Tupi), Bandeirantes Discos (Bandeirantes) e Seta (Record). É nesse momento em que a estrutura organizacional da indústria fonográfica brasileira se complexifica a partir de uma progressiva especialização. E ganha cada vez mais destaque e importância o papel do produtor artístico na produção fonográfica, cuja visão estratégica possibilitava a criação de produtos altamente vendáveis. A produção musical como categoria profissional se desenvolveu na década de 1950, nos EUA, quando o produtor passou de responsável pela direção e supervisão das sessões de gravação para uma espécie de mentor criativo, envolvido diretamente na concepção de um disco. (SHUKER, 1999, p. 219) Inclusive, muitos produtores de renome começaram a pressionar as gravadoras para receber não só os créditos nas gravações, como também direitos autorais sobre as canções vendidas. De fato, com o desenvolvimento das técnicas de gravação, como a tecnologia dos múltiplos canais e do som estereofônico, o produtor podia ser reconhecido como coautor e também como um intermediário cultural que pesquisava e captava tendências, descobrindo novas possibilidades e aprofundando a qualidade do trabalho de criação e gravação. Além do produtor, havia uma crescente verticalização e hierarquização na estruturação dos departamentos e setores das gravadoras multinacionais. ${ }^{45}$

45 Tal situação indicava uma estrutura bem mais complexa de profissionais distribuídos em diferentes áreas: artística (equipe de produção, composta por orquestradores, regentes e produtores); técnica (especialistas em áudio e eletrônica); comercial (marketing, capa/embalagem, produção, distribuição e promoção dos discos); e industrial (matrizes). (CERQUEIRA, 2015, p. 6) 
Ainda segundo Cerqueira (2015), a Phonogram, por exemplo, que contava com um contingente de 170 empregados e 150 artistas em 1968, passou a ter, em 1974, 500 funcionários para atender apenas a 28 artistas. Isso era um reflexo direto do crescimento da indústria do disco brasileira e da modernização do setor, que crescia $15 \%$ ao ano em média - mesmo diante de dois momentos de falta de matéria-prima, por ocasião das crises internacionais do petróleo na época -, seguindo a ampliação do mercado de bens de consumo, com destaque especial para a venda de aparelhos de reprodução sonora. (MORELLI, 2009, p. 61) O mercado brasileiro apresentava, assim, um grande potencial, e outras majors se estabeleceram no país, interessadas em comercializar aqui sucessos internacionais.

A repressão e a censura também dificultavam a expansão do mercado de música popular brasileira, o que facilitava e incentivava ainda mais o lançamento, por parte das multinacionais, de sucessos estrangeiros, que passaram a predominar nas programações das emissoras de rádio e nos suplementos das gravadoras. (MORELLI, 2009, p. 62) Essa condição aumentava muito os lucros, visto que era muito mais barato lançar aqui um disco já gravado no exterior do que gravar um LP com artistas brasileiros. Além disso, os discos estrangeiros já tinham seus custos de gravação cobertos pelas vendas realizadas em seus mercados de origem. Ainda segundo Morelli (2009, p. 62), havia outra vantagem para as filiais instaladas no Brasil, que, apesar dos altos impostos sbre importação de gravações, as faziam entrar no país como “amostras sem valor comercial”, prática proibida por lei, mas tolerada pelas autoridades.

Em Morelli (2009, p. 63), é possível ainda encontrar alguns índices que demonstram a ocupação massiva do mercado brasileiro pela música estrangeira, notadamente a norte-americana. Levantamentos semestrais realizados pelo Jornal do Brasil no primeiro semestre de 1971 apontam que a música nacional ocupava 57,5\% do chamado "mercado de sucesso", mas logo no semestre seguinte ocupou apenas $37 \%$ desse mesmo mercado, caindo para apenas $16 \%$ no primeiro semestre de 1972 , com uma pequena recuperação no segundo semestre daquele ano, atingindo 17,5 pontos percentuais.

No começo dos anos 1970, 47\% de todos os discos fabricados no Brasil apresentavam artistas estrangeiros ou versões de músicas estrangeiras, de 
acordo com Dunn (2009, p. 191). Na intenção de tentar participar desse segmento, muitos eram os artistas que gravavam versões em português de sucessos internacionais ou cantavam em inglês. Vários cantores e bandas da época, inclusive, se apresentavam com nomes estrangeiros. Assim, uma boa parte dos artistas internacionais que faziam sucesso no Brasil, ironicamente, eram brasileiros. Como exemplo, havia Terry Winter, Michael Sullivan, Mark Davis (Fábio Jr.), Morris Albert, Christian, Demis Rousseau, Dave MacLean, Dee D. Jackson e bandas como a Light Reflections e Lee Jackson. O inglês se consolidava como o idioma do futuro, do consumo, e essa estratégia era utilizada como forma de conquistar um público brasileiro mais interessado em sonoridades importadas, sugerindo que "a adoção da língua inglesa e da postura internacional por parte dos artistas configurava-se como uma opção estratégica passível de conferir a seus trabalhos uma maior legitimidade junto aos jovens consumidores urbanos”. (VICENTE, 2009, p. 5) De certa forma, na década de 1970, pode-se perceber o encerramento de um processo cultural começado 50 anos antes de busca de uma identidade nacional brasileira, especialmente quando se observa como a esfera musical popular equacionou impasses, tensões e polêmicas criados ao longo do período. (NAPOLITANO, 2002a, p. 75) Esse momento correspondia a uma revisão de tradições anteriores e da própria memória musical, em que a música e o mercado passaram a absorver ou aderir aos modelos da música pop, abrindo-se esteticamente para novas formas e novos produtos.

\section{O segmento do soul}

A grande quantidade de lançamentos, sejam estrangeiros ou nacionais, não deixava dúvidas a respeito do crescimento acelerado do mercado consumidor brasileiro de discos nos anos 1970, que incorporava novos segmentos da população com um crescente poder de compra. Mesmo assim, apesar do empenho da indústria fonográfica para aproveitar o mercado brasileiro na venda massiva de rock internacional, bandas mais famosas, como Led Zeppelin e Deep Purple, aqui não obtiveram vendas expressivas. O mercado nacional tinha características peculiares e precisava ser explorado de maneiras diferentes. 
A música negra norte-americana já era razoavelmente consumida nos subúrbios do Rio, primeiro por meio do rock'n'roll de cantores como Chuck Berry e Little Richards, cujas carreiras foram ofuscadas por Elvis Presley. No Rio de Janeiro, a Jovem Guarda e os Beatles ocuparam a faixa musical destinada aos jovens nos anos 1960, além de conjuntos de baile, como Golden Boys (influenciados pelo doo-wop), The Fevers, Renato e seus Blue Caps. Cantores negros de "balanço" (ou samba-rock, samba-soul) também eram bastante requisitados, como Jorge Ben (antes de ser Ben Jor), Bebeto e Wilson Simonal, que faziam sucesso nos clubes do subúrbio e começavam a introduzir em suas canções sonoridades do soul. As primeiras gravadoras que se interessaram pela proposta foram a Top Tape e Tapecar, de porte mais modesto, que criaram eficientes estratégias de negócio ao contratar as duas equipes mais famosas, a SGP e a Dynamic Soul, para o lançamento de coletâneas com o repertório dos bailes de soul.

Outra equipe, a Sorac, também assinou contrato com a Top Tape, que investia no segmento e, apenas em um mês, em maio de 1976, lançou seis discos de soul, enquanto a Love Som fechou com a Phonogram. De acordo com Frias, os discos eram lançados com tiragens entre 10 e 20 mil cópias, que vendiam com facilidade, especialmente entre o público da Zona Norte: "Propositadamente, tiram-se poucas cópias, o que garante a raridade do disco e a possibilidade de relançamento posterior a preço bem mais alto. Ou a vendagem no câmbio negro, a preço que dependerá da qualidade da seleção musical”. (FRIAS, 1976, p. 4) Em seguida, a SGP foi contratada pela Warner, Elektra e Atlantic (WEA), recém-chegada ao Brasil e interessada em atingir um mercado jovem mais amplo. Na segunda metade da década de 1970, a Warner Music, fundada em 1954, conseguiu rapidamente ultrapassar a CBS, a RCA e a Capitol e tornou-se a maior gravadora e, por conseguinte, o maior conglomerado de entretenimento do mundo, garantindo uma participação de $25 \%$ no mercado norte-americano. (MIDANI, 2009, p. 98) Desde 1960, o espetacular crescimento do mercado mundial da indústria fonográfica havia chamado a atenção dos grandes conglomerados da comunicação, que compraram todas as companhias independentes de discos que existiam no mundo.

Em junho de 1976, a Warner abriu uma filial no Brasil e se dedicou a vender seu catálogo norte-americano no país, reproduzindo matrizes 
estrangeiras para atender a uma demanda crescente de consumidores mais jovens no mercado brasileiro, conquistando uma boa fatia do mercado nacional. Nos anos seguintes, passou a lançar números reduzidos de discos de artistas brasileiros de seu catálogo enxuto de contratados, o que garantiu uma ampliação de sua participação no mercado local, conquistando um público fiel e uma maior margem de lucros ao longo do tempo - a "faixa de prestígio”. Era a reprodução da mesma estratégia adotada por André Midani na Philips nos anos 1960. Com pouca rentabilidade, a Philips tornou-se sinônimo de MPB quando Midani, então principal executivo da gravadora, decidiu cortar vários artistas do seu cast, mantendo apenas 50 de 150 cantores. (ALONSO, 2011, p. 330) Em comum, os que restaram mantinham o foco na juventude urbana brasileira da época, como Caetano Veloso, Elis Regina, Jorge Ben, Gal e Chico Buarque, entre outros. Essa mesma estratégia de buscar um público jovem, mantendo um cast reduzido de artistas e explorando o catálogo internacional da gravadora, foi mantida por Midani, quando saiu da Philips-Phonogram para fundar a WEA no Brasil, ${ }^{46}$ se tornando um dos nomes mais importantes da indústria fonográfica do país. Além de conservar artistas da MPB que tinham surgido a partir do Tropicalismo (MORELLI, 2009, p. 101), investiu também no emergente segmento do soul brasileiro, como forma de aproveitar o sucesso do gênero no contexto internacional.

A divisão fonográfica da Warner Communications possuía três selos: Warner, Elektra e Atlantic, que se comportavam ainda como gravadoras independentes. Pois, mesmo tendo sido vendidas, os donos dos selos permaneciam na liderança, com grandes participações nos lucros de suas marcas. A Atlantic Records tinha um catálogo independente, especializado em artistas de jazz, soul e R\&B, como Ray Charles, Roberta Flack e Aretha Franklin, e foi adquirida pela Warner em 1967. A vantagem de possuir um vasto catálogo musical era um "importante trunfo para a produção de coletâneas,

46 Na Philips, Midani também passou a empregar outra estratégia. Primeiro, separou a "nata” da MPB e cantores mais popularescos em dois selos: Philips e Polydor. E os artistas que vendiam 4 mil discos que permaneceram na Philips passaram a receber todas as atenções da gravadora, que realizava campanhas de marketing, peças publicitárias, investia mais em produção, tecnologia e divulgação, passando a vender 40, 50 mil cópias. Com isso, a gravadora tornou-se bastante lucrativa, aumentando sua participação de $7 \%$ a $8 \%$ para $18 \%, 19 \%$ do mercado. (MIDANI, 2009) 
compilações e mesmo para a consolidação no mercado de novos formatos". (VICENTE, 2002, p. 335) Assim, para aproveitar o catálogo da Atlantic, a WEA passou também a investir na cena black nacional, se tornando uma espécie de "ponto de convergência para muitos eventos relacionados com o movimento black, promovidos por DJs nos subúrbios do Rio e de São Paulo”. (MIDANI, 2009, p. 102) André Midani considerava que a Black Rio poderia ser o primeiro movimento musical inteiramente negro a produzir um tipo de música que não fosse o samba (BAHIANA, 2006, p. 306) e investiu muito em seus contratados, pensando em criar uma espécie de Motown brasileira. ${ }^{47} \mathrm{Na}$ época, diante do fim de movimentos como a Jovem Guarda, a Tropicália e a Bossa Nova, o soul poderia ocupar esse espaço na produção de uma música para um público jovem.

O segmento fonográfico da soul music já vinha sendo explorado no Brasil há alguns anos. De acordo com Sansone (2004, p. 171), o primeiro disco de soul lançado no Brasil de que se tem conhecimento trazia o título inglês What is soul?, lançado em 1967 pela CBD. O LP apresentava uma compilação de diversos cantores - Aretha Franklin, Percy Sledge, Joe Tex, The Capitols, Wilson Picket, Sam \& Dave etc. - e a capa exibia uma foto de jovens brancos dançando ao lado de uma descrição do que seria o soul. Tanto pela foto quanto pelo texto, percebia-se a estratégia da gravadora de desvincular a sonoridade de uma produção racializada, atrelada diretamente à cultura negra urbana norte-americana, ignorando a utilização corrente, nos EUA, da expressão black music. ${ }^{48}$ A proposta da gravadora, naquele momento, era apresentar o

47 Nirto, da SGP, fala a respeito do investimento na busca de novos talentos: "Aí alugaram para a gente um apartamento em Ipanema, na Visconde de Pirajá, e deram um gravadorzinho para registrar tudo o que tivesse em termos de black brasileiro". (ESSINGER, 2005, p. 36)

48 "Dia a dia surge uma novidade no mundo da música em todos os cantos do mundo. E cada inovação ganha sempre um nome pequenino, mas com a intenção de definir algo muito grande e elevado. Assim é o 'soul', a última inovação surgida no mundo da música e que consegue uma aceitação das maiores, principalmente pelo público jovem que, como sempre, é o primeiro a aceitar, adotar e beber o que vem com característica de novidade. As letras contêm mensagens de muito sentimento e ternura, embora o ritmo seja alegre e bem dentro da linha do que o jovem prefere e exige... É o que se dança e se canta em todas as boates ianques, em todas as 'caves' de Paris e do resto da Europa. E como o vento é que traz ligeiro as novidades musicais, num instante ele se fez presente no Brasil, onde aos poucos começa a infiltrar-se...”. (SANSONE, 2004, p. 171) 
soul como uma novidade popular da música jovem da época, moda em boates europeias, desarticulando essas produções de uma possível associação a questões de raça, especialmente a um discurso de afirmação de uma negritude - mesmo que a maioria dos cantores que figuravam nessa coletânea fossem negros.

No começo dos anos 1970, o soul ocupava lugar de destaque nos índices de vendagens de compactos simples no Brasil, como o do grupo Greaves, com o disco Take a Letter Maria (ATCO, 1970), o conjunto Sly \& The Family Stone (Thank You, Epic, 1970) e o compacto Yester me, Yester you, Yesterday (Tamla, 1970), de Stevie Wonder, que ficou entre os 20 mais vendidos no país, segundo o Instituto Brasileiro de Opinião Pública e Estatítisca (Ibope). (SCOVILLE, 2008, p. 36) Já o soul brasileiro de cantores como Tim Maia e Hyldon também era um gênero bastante consumido naquele momento. Dados do Nelson Oliveira Pesquisas de Mercado (Nopem), baseados em informações de lojistas do Rio e São Paulo, ${ }^{49}$ apontam que o segmento do soul, categorizado conjuntamente com rap e funk, de 1971 a 1977, manteve, anualmente, de 1 a 2 discos entre os 50 mais vendidos de cada ano. Ao analisar esses dados, Vicente (2009) constatou que, em 1971, Tim Maia, com o disco homônimo (Tim Maia, Philips), ficou em $26^{\circ}$ lugar, sendo citado mais a frente, em 1974, junto com Hyldon (Na rua, na chuva, na fazenda, Philips, $28^{\circ}$ lugar), que, no ano seguinte, ficou em $32^{\circ}$ lugar com Na sombra de uma árvore (Philips, 1975). Em 1976, Cassiano ficou em $25^{\circ}$ lugar (A Lua e eu, Philips) e Cláudia Telles (Fim de tarde, CBS) em 50 $0^{\circ}$ lançada pela CBS naquele momento como uma versão brasileira de Diana Ross. É importante lembrar que a Philips tinha um forte segmento de soul music por conta da atuação de André Midani, que manteve seu apoio à black music brasileira também na WEA.

O soul também foi bastante representativo no V Festival Internacional da Canção (FIC) de 1970, que expôs o gênero para uma maior audiência por

49 “A Nopem, Nelson Oliveira Pesquisas de Mercado, é uma empresa carioca criada em 1965 com o objetivo de atender exclusivamente à indústria fonográfica. Nelson Oliveira, seu fundador, trabalhara anteriormente no lbope e estruturou sua pesquisa de venda de discos a partir de informações de lojistas do eixo formado pelas cidades do Rio de Janeiro e São Paulo. As listagens não trazem quantidades de vendas, mas apenas a posição anual de cada álbum no ranking dos 50 mais vendidos". (VICENTE, 2006, p. 2) 
meio de novos cantores, como Tony Tornado, o conjunto Dom Salvador \& Abolição, o Trio Ternura e Erlon Chaves. As canções "BR-3", vencedora da etapa nacional do V FIC na voz de Tornado, e "Eu também quero mocotó" foram amplamente executadas nas rádios, o que ajudou na venda de seus respectivos compactos, potencializando o soul no mercado. E, de certa forma, o evento "serviu de campo de sondagem, que desta vez atuou a favor da indústria fonográfica, que buscava uma reformulação na produção musical” (SCOVILLE, 2008, p. 35), potencializando o segmento do soul. O FIC também funcionava como uma espécie de celeiro de novos sucessos para a programação musical e para a trilha das novelas da Rede Globo, uma das realizadoras do festival.

Outra gravadora que investiu no soul foi a Tapecar, que editou no país títulos da Motown e LPs de artistas da Tamla. A Tapecar era uma gravadora industrial e fábrica de cartuchos sonoros para carros e se transformou em selo musical no início da década de 1970, também lançando discos de samba e MPB ${ }^{50} \mathrm{O}$ segmento ainda envolveu outras grandes gravadoras do país, como a CBS, ou menores, como a Top Tape e a Continental, de acordo com Dias (2000, p. 76), e ainda a Phonogram, cujo gerente de produtos, Roberto Menescal afirmou na época: “[...] eu diria que a saída é o soul, porque o pessoal do black soul amanhã vai acabar fazendo black samba. Vai ser legal porque vai trazer uma nova maneira de ver o samba”. (BAHIANA, 2006, p. 306) Às gravadoras, de fato, não poderia ser creditado exclusivamente o sucesso do soul no Brasil. Mas, de fato, os executivos das companhias estiveram atentos ao fenômeno, inclusive desenvolvendo estratégias para dar mais visibilidade ao movimento e, por conseguinte, chamar a atenção da imprensa e do público para futuros lançamentos discográficos, como assume André Midani (2009, p. 103) em seu livro Música, ídolos e poder, após ir a um baile black no subúrbio carioca:

Nas semanas seguintes, chamei jornalistas cariocas e paulistas que eu conhecia, e organizei várias caravanas para Olaria. As

50 A empresa encerrou suas atividades em 1980, ao vender seu catálogo para a Som Livre. Na década de 1990, todo o seu acervo foi licenciado à Discos Copacabana, que posteriormente foi adquirida pela EMI. Desde 2011, o acervo da Tapecar vem sendo restaurado e digitalizado pelo selo Discobertas. 
reportagens começaram a aparecer no Rio e em São Paulo, criando uma controvérsia grande, a favor e contra os blacks, sua cultura e sua música, que muitos julgavam alienada, temendo que tais manifestações viessem a destruir a tradição secular dos morros. Para culminar, a revista Veja publicou em 1978 uma longa reportagem de seis a sete páginas, ampliando os debates e pondo fogo nesse confronto entre 'Velhas Guardas versus Jovens Guardas', que no final se resumia a 'samba versus soul', ou 'tradição versus evolução'. Pouca gente considerava que essas modalidades pudessem conviver. ${ }^{51}$

Outro célebre texto que descortinou os bastidores das ações empresariais da indústria fonográfica em torno do movimento foi redigido pela jornalista musical Ana Maria Bahiana e publicado em fevereiro de 1977 no Jornal da Música, que tinha grande circulação na época. No artigo "Enlatando Black Rio”, republicado em 2006, Bahiana abordava a suposta manipulação por parte das gravadoras do mercado black, reafirmando o movimento soul como mais uma criação da indústria cultural sem qualquer fundamento político e que poderia angariar altos ganhos para as gravadoras:

Um mercado de bom tamanho - de 10 a 20 mil consumidores certos -, com índice ótimo de homogeneidade e resposta a estímulos. Um mercado que podia, bem manipulado, ser o estopim de outro muito maior, Black São Paulo, Black Salvador [...]. (BAHIANA, 2006, p. 305)

Uma das estratégias empregadas com ampla lucratividade era o lançamento de coletâneas com os nomes das principais equipes ou dos DJs mais famosos, que poderiam fazer uma espécie de curadoria. Restrições de importação limitavam severamente a chegada ao mercado de discos brasileiro de selos norte-americanos independentes, como Motown e Stax, o que favorecia as majors com afiliadas brasileiras como a CBS e a Philips. Essa vantagem permitia que as multinacionais, ao lado de selos brasileiros regionais,

51 Midani se confunde porque, na verdade, a revista Veja publicou duas matérias abordando a Black Rio, sendo a primeira, com cinco páginas, em 1976 e a segunda, com apenas duas páginas, em 1978, esta um obituário sobre o falecimento do compositor Candeia. 
adquirissem os direitos para distribuir singles americanos independentes no país, lançando coletâneas localmente que rendiam altos lucros. No princípio, gravadoras menores, como a Continental, Top Tape e a Tapecar, lançaram as primeiras coletâneas com repertórios dos hits mais tocados por equipes famosas. (BAHIANA, 1980, p. 218) Sem perder tempo, os diretores de outras grandes gravadoras multinacionais com sede no Brasil logo se mobilizaram para também aproveitar a onda black no mercado do disco, empurrando selos domésticos para as margens. Por volta de 1977, além da Warner, todas as gravadoras brasileiras, incluindo a CBS, a Polygram e a Phonogram, antiga Philips, tinham em mãos uma série de projetos relativos à formação de uma cena black na música brasileira, e o movimento ganhou projeção nacional. (RAMOS, 2007, p. 65)

Assim, as músicas mais tocadas nos bailes poderiam ser adquiridas pelos participantes, ou novos lançamentos do catálogo das gravadoras passavam a ser tocados diretamente nos bailes, que tinham um alcance maior do que a rádio ou a TV naquele contexto. As coletâneas de hits funcionavam também como peças de divulgação de vários novos artistas da black music internacional em um mesmo produto, tornando-o bastante atrativo, especialmente em um momento de retração no consumo ocasionado pelo fim do milagre econômico. Mesmo diante da recessão, o mercado de aparelhos de reprodução sonora cresceu em $813 \%$ até o começo da década de 1980 (ORTIZ, 1999, p. 120), e as coletâneas colaboraram de forma decisiva para a ampliação do mercado fonográfico brasileiro, garantindo publicidade e alta lucratividade a um custo bem mais baixo. A gravadora repassava uma parte das vendagens para as equipes, que se tornaram cada vez maiores e mais rentáveis. Esse êxito também acompanhava o aumento da popularidade da música americana vendida no Brasil por intermédio das afiliadas locais. O poder econômico das multinacionais ainda garantiu uma maior distribuição de discos por todo o país, bem como a compra de espaços publicitários na TV, e o soul entrou até nas trilhas sonoras de novelas e de programas musicais nacionais.

Bahiana (2006) também documentou em um dossiê o investimento no soul realizado por outras gravadoras, como a Phonogram-Polygram, ainda bastante articulada ao mercado da MPB, que investia no soul brasileiro de 
Cassiano e Tim Maia, além de lançar o primeiro disco da União Black ${ }^{52}$ para concorrer com a Banda Black Rio da WEA, tendo à frente o cantor Gerson King Combo, que logo depois lançou seu primeiro disco solo, em 1977. Esses nomes deram forma à divisão interna desse segmento na gravadora, estratégia semelhante à da CBS, que desejava ocupar a faixa de mercado dominada pela música americana contratando o cantor e compositor Robson Jorge - que trabalhou com Tim Maia -, autor do sucesso "Fim de tarde", interpretado por outra contratada da gravadora, Cláudia Telles, trabalhada pela CBS para ser uma versão nacional da cantora Diana Ross. Ainda integravam o cast da gravadora a mineira Rosa Maria e o grupo Alma Brasileira, composto por integrantes da escola de samba carioca Mocidade Independente de Padre Miguel. Para dar o pontapé inicial no segmento soul, a CBS organizou a coletânea Brasoul, LP lançado simultaneamente no Brasil e nos EUA, representando a decisão da companhia de trabalhar com o segmento soul no mercado brasileiro e americano ao mesmo tempo. A Continental foi a última a penetrar no mercado black, contratando o cantor e compositor Dom Mita, que misturava samba e soul utilizando instrumentos como o surdo no lugar do contrabaixo e substituindo a guitarra pelo cavaquinho. Outros cantores de soul brasileiros também foram lançados, mas sem muito sucesso, como Miguel de Deus e Tony Bizarro.

A Som Livre, gravadora brasileira pertencente à Rede Globo, tinha um acordo com a Top Tape, que detinha os direitos de distribuição da gravadora Motown no Brasil. Assim, o repertório internacional das trilhas sonoras das novelas globais, a partir de 1971, passaram a apresentar uma quantidade imensa dos contratados da Motown, como Stevie Wonder, Michael Jackson, Gladys Knight \& The Pips. Muitas das canções incluídas nas trilhas rapidamente eram lançadas em compactos, que logo entravam para a lista dos mais vendidos. O programa Som Livre exportação, veiculado pela Rede Globo de 1970 a 1971, também ampliou a divulgação do soul no Brasil, consolidando

52 Segundo Essinger (2005, p. 38), a União Black era originalmente um grupo de samba do subúrbio: "Com o aval do produtor e integrante dos Fevers Pedrinho da Luz, Gerson então conseguiu roupas blacks para a rapaziada, ajudou na composição das músicas e o disco foi feito. A foto da capa, curiosamente, foi tirada com a banda posando nas ruínas do Astória, lá onde começara Mr. Funky Santos". 
a tendência no mercado de discos. Ocupando a lacuna deixada pelos extintos programas O fino da bossa, Jovem guarda e Divino, maravilhoso, da década de 1960, com recorrentes apresentações de músicos como Tim Maia e Tony Tornado, o programa Som Livre exportação era também resultado da parceria comercial com a Philips-Phonogram - maior gravadora do país, que tinha em seu cast todos os grandes nomes da MPB, menos Roberto Carlos -, que também tinha um acordo com a Rede Globo para a produção de todas as trilhas de telenovelas. (SCOVILLE, 2008) Responsável por altos índices de vendas, o soul tornou-se um segmento rentável e lucrativo, concretizando as expectativas dos críticos ao movimento, que denunciavam o caráter mercantilizado da Black Rio.

\section{A Banda Black Rio}

Com o sucesso dos bailes e a maior difusão de gêneros da black music norte-americana nas rádios brasileiras, artistas nacionais que cantavam soul music começaram a despontar e a gravar discos de grande sucesso. Mesmo antes desse êxito alavancado pelos bailes, a black music já influenciava o trabalho de muitos artistas brasileiros. Além dos já consagrados Tim Maia ${ }^{53}$ e Jorge Ben Jor, novos nomes como Hyldon e Cassiano, antigos parceiros de Tim Maia, angariaram excelentes resultados para a indústria fonográfica. Tony Tornado, Bebeto e Gerson King Combo, diferentemente dos outros cantores de soul brasileiros, ganharam impulso em suas carreiras ao articularem diretamente suas imagens aos bailes black, realizando grandes shows a partir de contratos com as equipes de som.

A boa repercussão do segmento incentivou a WEA, Warner Music do Brasil, que, em 1977, incumbiu ao músico Oberdan Magalhães, a pedido da matriz norte-americana, a criação de uma banda que mesclasse a soul music com a música negra brasileira mais conhecida no exterior: o samba. "A Warner está animadíssima, tem toda uma transação em cima de música negra,

53 Sobre a importância do soulman Tim Maia, Ramos (2007, p. 68) comenta: “Os Lp(s) lançados por ele ao longo dos anos 70 são bases fundamentais da música pop que se desenvolveu no Brasil nas décadas seguintes e estão entre os exemplos mais bem acabados de nossa música em termos de produção de discos dentro de um estúdio". 
sabe, eles estão formando uma banda, o Oberdan e esse pessoal, eles estão recebendo um fixo para ensaiar todo dia e criar um som black brasileiro", comentou Marinaldo Guimarães, na época, empresário do cantor Luís Melodia. (BAHIANA, 2006, p. 303) Inicialmente chamada de Black Rio Band, contava com Oberdan no sax e outros músicos, como Barrosinho no trompete, Luís Carlos Batera, Cristóvão Bastos ao piano, Claudinho Stevenson na guitarra, Lúcio do Trombone e Jamil Joanes no baixo, músicos experientes, mas "[...] do subúrbio, marginalizados no mercado da MPB fina". (ESSINGER, 2005, p. 37) Com produção artística de Dom Filó, na época também contratado da WEA, surgia, assim, a Banda Black Rio, após três meses de ensaios. ${ }^{54}$

O som produzido pela banda era uma grande fusão entre a black music internacional, o samba - especialmente o samba de gafieira - e a improvisação "jazzística", a partir de uma base instrumental que executava arranjos originais e demonstrava a competência dos músicos integrantes do grupo. Oberdan demonstrava, com esse trabalho, as influências que recebera do universo do samba e o do jazz. Além de sobrinho do sambista Mano Décio da Viola, Oberdam era primo de Silas de Oliveira, um dos fundadores da escola de samba carioca Império Serrano e compositor do consagrado samba "Aquarela do Brasil”. E o músico começou a estudar música com Paulo Moura, um dos mestres do saxofone brasileiro, quando tinha 15 anos. (RAMOS, 2007, p. 70) Diante do convite da Warner, o músico convidou alguns membros do grupo Impacto 8 - formado em 1967, que também deu origem à Banda Abolição, liderada pelo pianista Dom Salvador - e também dos conjuntos Senzala e Cry Babies. Nascia assim, ao final do ano 1976, a formação original da Black Rio.

54 "A gravação que o Mazzola produziu com a Banda Black Rio foi um momento muito importante na vida musical do país, pois o grupo reunia os mais importantes músicos black do Rio de Janeiro. Oberdan, líder da banda, desenvolveu arranjos surpreendentemente ousados e modernos, que fizeram com que o álbum Maria Fumaça se tornasse, até hoje, uma referência entre os músicos brasileiros devido ao seu conceito inovador e, sobretudo, à influência que exerceu sobre os destinos musicais do funk brasileiro, que estava nascendo, inicialmente pela influência musical do Jorge Ben Jor, do Tim Maia e, naquele momento, dessa banda. O negro podia se expressar de muitas maneiras - sem ficar unicamente confinado ao samba e, no entanto, sem o renegar". (MIDANI, 2009, p. 102) 
No começo, a banda não atendeu imediatamente às expectativas da indústria fonográfica. Sua primeira apresentação-teste, acompanhando o cantor Luís Melodia em uma performance ao vivo em um show no MAM, Zona Sul do Rio, e depois durante um baile no Clube Olaria, no subúrbio, não cativaram o público, particularmente por conta da ênfase em composições instrumentais, que não dialogavam diretamente com os fãs da black music naquele momento, segundo Ramos (2007). Mas André Midani e a WEA já consideravam essa reação, visto que a proposta da banda era fazer música de "alto nível”, comparável ao trabalho de músicos como Hermeto Pascoal e Egberto Gismonti: "Ela é instrumental, mas ligada ao som das gafieiras, aos bailes populares, ao Astor e Seu Conjunto, que foi a formação desses músicos”. (BAHIANA, 2006, p. 309) Oberdan Magalhães também explicou após o espetáculo: "O som da banda não é propriamente feito para dançar, nós estamos a fim de fazer um som forte, uma música alegre”. (BAHIANA, 2006, p. 308) Uma solução para tornar os shows da Banda Black Rio mais populares foi a contratação dos cantores Sandra de Sá e Carlos Dafé - que depois seria contratado pela WEA em carreira solo - para acompanhar o grupo nas apresentações seguintes. O primeiro disco, Maria Fumaça (1977, Warner), era inteiramente instrumental e trazia clássicos da música brasileira em versões repaginadas, como "Na Baixa do Sapateiro", de Ary Barroso, e "Casa Forte", de Edu Lobo, em uma proposta clara de renovação e mistura de sonoridades e gêneros. Sobre o disco, Oberdan comentou: "Essas músicas mostram todo sentido da alquimia e da transformação que estamos propondo, porque a música popular brasileira precisa ser renovada, remexida, com todos os sons, sem preconceitos". (BAHIANA, 2006, p. 310)

A crítica especializada elogiou o trabalho, apesar do disco não ter obtido grandes índices de vendagem. Não tanto quanto discos de hits dos bailes lançados por DJs e equipes de som de gravadoras independentes, como a Top Tape e a Tapecar. Mesmo assim, a Banda Black Rio conseguiu ter suas músicas circulando em nível nacional, em especial por conta da participação na trilha sonora de uma novela global - a faixa "Maria Fumaça" foi incluída na trilha da novela Locomotivas, em 1977. No ano seguinte, a banda acompanhou Caetano Veloso na turnê Bicho Baile Show, em maio de 1977, com o repertório de canções do LP Bicho (Philips, 1977). O show, que tinha um mote 
mais dançante e pop, foi levado até para a quadra da escola de samba Beija Flor, em Nilópolis, a fim de atingir um público mais popular. Seu registro ao vivo foi lançado em CD apenas décadas depois, mas o show representou um momento de grande projeção para a banda. ${ }^{55}$ Em 1978, com menos canções instrumentais e um apelo mais comercial, o grupo lançou o segundo disco, Gafieira universal, pela RCA-BMG.

A mudança para a RCA trouxe alterações concretas na proposta sonora inicial do grupo, a fim de popularizar mais o trabalho, e a gravadora impôs a inserção de vocais e a produção de gravações com uma roupagem mais pop, o que não foi aceito por alguns integrantes, que abandonaram o grupo. O terceiro LP, Saci Pererê (RCA Victor, 1980), foi lançado já no declínio da cena da Black Rio, mas a banda continuou fazendo shows até o falecimento de Oberdan, em um acidente de carro em 1984.

Ao lado da Banda Black Rio, os grupos Dom Salvador \& Abolição e União Black inspiraram o surgimento, no subúrbio carioca, de alguns conjuntos oriundos de festas e gafieiras, que criaram um circuito paralelo, mas convergente à cena dos bailes black. Esses conjuntos eram também influenciados por grupos de funk norte-americanos, como Earth Wind and Fire e KC \& The Sunshine Band, e ainda pelas orquestras de gafieira tradicionais. Ainda hoje em atividade, conjuntos de baile como Copa 7, Os Devaneios e a Banda Brasil Show executavam canções de sucesso e também composições próprias, todas voltadas para a execução de passos de dança no salão, em que os arranjos de metais eram articulados a teclados, baixos e guitarras, que modularam uma sonoridade até hoje identificada com a prática do samba de gafieira moderno, mesclando samba e black music.

\section{MPB+soul}

E a soul music, que chegava ao Brasil através dos bailes, começava efetivamente a ocupar a significativa fatia da música estrangeira nas gravadoras

55 Sobre esse show, Caetano Veloso comenta em artigo publicado na Revista Música de 1977: “[...] o show é bem uma apresentação de banda. Eu estou presente, a minha transação se dá por inteiro. É bacana, mas é bem mais uma apresentação de banda. Eu fiz questão que fosse assim, porque eles são músicos muito bons”. (RAMOS, 2007, p. 71) 
nacionais, se fazendo também mais presentes no universo composicional da MPB que, naquele momento, já havia absorvido a ideologia tropicalista baseada na incorporação de elementos da cultura de massa. A sigla MPB foi um rótulo fonográfico que incorporava vários gêneros e estilos musicais urbanos desenvolvidos a partir de 1965 e simbolizava especialmente a música popular urbana do período pós-tropicalista. A MPB acabou por forjar uma identidade estética e ideológica para setores médios dos principais centros urbanos, especialmente para uma pequena parcela universitária ou para grupos de intelectuais e artistas, e correspondia a um imaginário coletivo de uma resistência política e cultural. O termo guarda-chuva englobava a moderna produção musical massiva urbana que emergiu a partir da Bossa Nova (NAPOLITANO, 2002b), reunindo uma série de convenções culturais, movimentos e estilos que atualizaram a tradição do samba, exercendo novos cânones e padrões de valor e autenticidade. Sob o aval da indústria fonográfica do período, a MPB era caracterizada por uma produção musical que reunia apuro estético e pesquisa de tradições nacionais populares, com o objetivo de criar composições “de qualidade”, mas que, especialmente após a Tropicália, passou a dialogar com influências massivas do pop internacional.

A popularidade no país de nomes como Aretha Franklin, James Brown e Stevie Wonder aumentava e também exercia grande influência sobre muitos artistas brasileiros. Compositores, músicos e arranjadores começaram a inserir mais veemente em suas canções elementos anteriormente considerados antagônicos, renovando suas estratégias midiáticas e popularizando seus trabalhos em consonância com novas tendências de consumo. Essa hibridização não era uma prática nova e correspondia a uma nova etapa da incorporação de gêneros estrangeiros à música brasileira, como ocorreu com o jazz (com o samba-jazz e a bossa nova), depois o rock (com a Tropicália e a Jovem guarda), atualizada naquele momento pelo contato com a black music norte-americana.

De certa forma, já em 1969 a tendência da introdução do soul na MPB começava a se confirmar, especialmente com o êxito da gravação por Roberto Carlos do soul "Não vou ficar". Um ano depois, Elis Regina gravou "These are the songs" (Em pleno verão, 1970, Philips), um dueto com Tim Maia, compositor da canção e também autor do sucesso de Roberto Carlos. Foi o 
pontapé inicial para uma carreira de sucesso e para a consolidação do soul no cenário musical brasileiro. Tim Maia, que já havia estourando nas rádios no final do ano anterior com "Primavera", lançado em um compacto simples, gravou seu primeiro disco, Tim Maia (Polydor), em junho de 1970. Acompanhado pelos Diagonais, grupo liderado pelo guitarrista e compositor Cassiano e acompanhado pelos músicos Hyldon, Camarão e Amaro, Tim Maia se tornou o principal representante do núcleo do soul brasileiro, ao lado de Jorge Ben. Mas as características estilísticas dos dois músicos diferenciavam-se, no sentido de que Tim Maia se voltava mais para uma produção ligada à black music norte-americana original, enquanto Jorge Ben se interessava por hibridizar o samba de diversas maneiras.

Alguns compositores de MPB, como Marcos Valle, de origem bossa-novista, e Ivan Lins, aderiram ao soul, tal como António Adolfo e Tibério Gaspar, dupla de compositores de procedência jazzística que encontraram no soul o caminho para o sucesso, vencendo o $5^{\circ}$ FIC com "BR-3", interpretada por Tony Tornado em 1970. O $5^{\circ}$ FIC, em especial, promoveu o então novo segmento do mercado, potencializando o soul na indústria fonográfica. No festival, outras composições também obtiveram destaque como "O amor é o meu país”, de Ivan Lins, e “Abolição 1860-1980”, do conjunto Dom Salvador e Abolição. A composição "Eu também quero mocotó”, de Jorge Ben Jor, foi defendida pelo maestro e arranjador Erlon Chaves, acompanhado pela Banda Veneno, e ficou em sexto lugar. A canção, ao lado de "BR-3", foi uma das favoritas do festival, amplamente executada nas estações de rádio, motivando grandes vendas de seus respectivos compactos.

\section{Brazilian disco music}

Para Bahiana (1980, p. 48), em meados dos anos 1970, duas linhas de produção emergiram nos EUA: uma se manteve mais fiel aos padrões de gosto das populações jovens e negras - o soul repaginado e transformado em funky music-; e a outra aproveitava apenas os padrões rítmicos e o pulso dançante em formas mais diluídas e comerciais para um público mais amplo - a discothèque. O crítico musical Tárik de Souza (1976, p. 10) considerava a disco uma "espécie de filial pilantragem do soul", em referência ao movimento 
encabeçado por Wilson Simonal nos anos 1960, baseado em canções mais comerciais, divertidas e dançantes que seguiam fórmulas pré-determinadas. Em torno de 1975, a moda mundial da disco music chegou ao Brasil através de nomes como Donna Summer, Chic, KC \& The Sunshine Band, Gloria Gaynor, entre outros, incluindo artistas originalmente identificados com o soul e funk que voltavam-se para a nova moda. De fato, como confirmam os dados da Associação Brasileira dos Produtores de Discos, em 1978, dos 30 álbuns mais vendidos em São Paulo e Rio de Janeiro, 16 eram LPs de discoteca. (RODRIGUES, 2003, p. 10)

Criada nos EUA e voltada para as pistas dos clubs, a disco music mesclava ingredientes do rock e do soul, mas sem sombra de pregação racial. A gravação "Soul Makossa”, do saxofonista camaronense Manu Dibango, lançada em 1972, é considerada uma das primeiras gravações do gênero e tornou-se um hit mundial. Apesar do sucesso comercial, a música disco foi frequentemente denegrida por alguns críticos por conta de sua influência pasteurizante sobre a música popular, a partir da utilização de baterias eletrônicas, teclados e sintetizadores (SHUKER, 1999, p. 99), em canções dançantes e melodiosas que falavam de amor, exaltavam a dança e a vida noturna. Para outros, no entanto, essa forma musical, apesar de considerada superficial e alienante, expressava, através da dança, uma vitalidade libertadora, inovadora e sensual. A disco emergiu a partir de uma "subcultura", no início dos anos de 1970, baseada em boates frequentadas por grupos negros e gays, e o gênero musical, no auge do sucesso, acabou por dominar a música pop por alguns breves anos, restaurando o hábito da dança como um "imperativo pop". (SHUKER, 1999, p. 99) As gravações de disco music continham, basicamente, pouca ou nenhuma letra, baseando-se em ritmos marcados e de batidas repetitivas (DOURADO, 2004, p. 109), e acabaram por influenciar toda a música pop mundial, dando origem à dance music e aos vários gêneros da música eletrônica. $\mathrm{O}$ Brasil também teve sua "diva disco", a cantora paulistana Lady Zu, cujo estilo era inspirado na cantora norte-americana Donna Summer. Lady Zu estourou com a música "A noite vai chegar" (Phonogram), carro-chefe do compacto de 1977, que vendeu um milhão de cópias, e foi incluída na trilha sonora da novela Sem lenço, sem documento, da Rede Globo. O sucesso lhe valeu o título de "Rainha da Discoteca Brasileira" e possibilitou a gravação do seu segundo LP, Fêmea 
brasileira (Phonogram), em 1979. Incorporando a moda das discotecas da época, os arranjos do LP fundiam a fórmula da disco music com gêneros nacionais, como o baião e o samba. Da moda musical disco, também participou o produtor e tecladista Lincoln Olivetti, que gravou com Robson Jorge a música "Aleluia" (Robson Jorge e Lincoln Olivetti, Som Livre, 1982), um grande sucesso nas rádios. Se, por um lado, Olivetti desfrutava de grande sucesso comercial nessa época, conhecido como "o mago do pop" por renovar a carreira de vários artistas da MPB, por outro, atraiu críticas que o responsabilizavam pela "pasteurização" do gênero nos anos 1980. Mentor da sonoridade funk-pop de "Realce", de Gilberto Gil (Realce, WEA, 1979), também foi um dos produtores de Salve simpatia (Som Livre, 1979), disco que marcou uma nova fase para a carreira de Jorge Ben Jor, de orientação mais voltada para as pistas de dança, com gravações densamente marcadas pela presença de sintetizadores, criando as bases de uma espécie de "disco-samba".

Os diferentes processos na indústria fonográfica mundial dos anos 1970, como a segmentação e massificação do mercado, abriram espaço para a oferta de uma produção musical mais pop, diante da internacionalização cultural e da evolução das novas tecnologias de gravação. Como pontua Vicente (2002), a maior racionalização e especialização das atividades da indústria, obtida por meio de uma divisão do trabalho mais complexa e de uma sofisticação das técnicas de marketing e de produção, ao mesmo tempo em que levava a uma maior padronização dos segmentos predominantes no mercado, "[...] deu voz e identidade a segmentos sociais antes absolutamente ignorados no contexto da mídia nacional”. (VICENTE, 2002, p. 199) 


\section{Blacks sob vigilância}

A cena Black Rio, ao alcançar a grande mídia, acabou por despertar críticas e reações que seguiam, basicamente, duas frentes. A primeira defendia a tese de que o Brasil era uma democracia racial, obtida graças à miscigenação de três raças: o branco português, o negro africano e o índio nativo. Segundo essa corrente, o país seria o paraíso do mulato, não havendo atualmente grandes problemas de preconceito racial, o que tornaria qualquer movimento negro artificial e deslocado da realidade nacional, uma tendência importada dos EUA que poderia ser prejudicial ao Brasil ao pregar uma marcada diferenciação racial que possivelmente conduziria a conflitos e tensões. (CAVALCANTI, 1981, p. 3) Havia ainda o receio de um distanciamento de uma autêntica cultura brasileira, alienando os participantes não apenas da "verdadeira” identidade nacional, como também de possíveis ações políticas eficazes de conscientização racial que deveriam ser pautadas em tradições afro-brasileiras. Outras críticas, advindas de uma esquerda com tendências comunista-marxistas, partiam do pressuposto de que o problema da desigualdade no Brasil seria uma questão de classe social e não de ordem racial, pressupondo que a união e a luta de classes dispensariam a necessidade de um movimento negro com ênfase na questão étnica. 


\section{A esquerda nacionalista e a alienação do soul}

"Black Rio: o orgulho (importado) de ser negro no Brasil", texto publicado em 17 de julho de 1976, é considerada a primeira matéria jornalística de relevo que trouxe para a Black Rio os holofotes da imprensa e chamou a atenção da cidade para a cena dos bailes. De autoria de Lena Frias (Marlene Ferreira Frias, 1943-2004), a reportagem de capa do segundo caderno do Jornal do Brasil revelava os bastidores do movimento, mas denunciava, nas entrelinhas, a crítica à vocação dos seus participantes para a celebração de uma identidade vista como "americanizada".

Lena Frias, naquele momento, se consagrava como jornalista e pesquisadora influente da música popular e cultura brasileira. Tinha trânsito livre entre compositores e intelectuais de esquerda e era ligada ao universo do samba e do Carnaval particularmente. No Jornal do Brasil, produziu outras reportagens de grande teor investigativo - chegando a se mudar para a Cidade de Deus para uma reportagem sobre a comunidade - e era entusiasta e amiga de artistas populares, como Clementina de Jesus e Candeia, defensora da "autêntica” cultura popular. ${ }^{1}$ Falar sobre a Black Rio, de certa forma, era uma novidade em relação aos seus temas comuns de reportagem. Convidada por um contínuo do jornal, um jovem branco chamado Everaldo - que se vestia como black para ir às festas -, Lena Frias foi pela primeira vez a um baile soul no clube Maxwell, em Vila Isabel, Zona Norte do Rio. ${ }^{2}$

A jornalista - ela mesma afrodescendente - também considerava o crescimento da Black Rio como um reflexo da segregação racial, portanto, não totalmente desprovido de valor e legitimidade. No artigo, há momentos em que a visão neutra da repórter apenas narra detalhes sobre os fatos, mas há

1 Além de jornalista, Marlene Ferreira Frias (1944-2004) pesquisava cultura popular e era muito ligada ao universo do samba carioca. Foi jurada durante alguns anos de desfiles de escolas de samba, fez parte do Conselho de Carnaval da Cidade do Rio de Janeiro, do Conselho Estadual de Cultura do Rio de Janeiro e, com Hermínio Bello de Carvalho e Nei Lopes, escreveu textos para o livro Rainha Quelé (2001), com organização de Heron Coelho, sobre a vida de Clementina de Jesus. Lena Frias faleceu em 2004, ano de seu último trabalho, um release sobre um CD de Dona Ivone Lara.

2 De acordo com José Sergio Rocha, jornalista, no site Agenda do Samba-Choro, em 12 de maio de 2004. Disponível em: <http://www.samba-choro.com.br/noticias/arquivo/9139>. 
passagens em que se posiciona favoravelmente em relação aos bailes, denunciando o racismo contido na repressão às festas e aos frequentadores. Mas, de forma geral, o texto ecoa um discurso de esquerda e um viés nacionalista, que considerava inautênticas e alienantes manifestações que tivessem um cunho "internacionalista" e "mercantilizado". No mesmo Jornal do Brasil, um ano depois, em 1977, o Secretário Municipal de Turismo do Rio de Janeiro, Pedro de Toledo Pizza, já declarava que "o Black Rio é um movimento comercial com uma filosofia racista”. (TURISMO..., 1977, p. 20)

Se, logo no título, percebe-se a ênfase irônica do argumento que critica a prática da "importação" de formas culturais estrangeiras, a denúncia dessa perspectiva política fica clara em passagens como "sabem tanto de soul quanto ignoram de cultura brasileira”. (FRIAS, 1976, p. 4) O tom da reportagem era de que as classes menos privilegiadas e a população negra deveriam assumir uma atitude mais "nacionalista", mesmo que ela reconhecesse que "embora sobre a cópia já se criem originalidades". Ao longo do texto, a jornalista também realçava a falta de um suposto sentido político para o movimento, enfatizando seu caráter de "modismo" e "imitação", pois "Frias se preocupava menos com a imitação da cultura estrangeira praticada por roqueiros brancos do que com a aparente alienação dos afrodescendentes em relação aos símbolos estabelecidos de uma cultura nacional afro-brasileira”. (ALBERTO, 2009, p. 18) Isso, de certa forma, endossava a ideia da jornalista de que era uma manifestação inofensiva e que, portanto, não deveria ser alvo de repressão policial, rejeitando também a hipótese de que o movimento seria uma espécie de mobilização que pregava a divisão racial, temida pela ditadura. Para Frias, os participantes, produtores, DJs e artistas estariam mais interessados em lucrar com o negócio do que em incentivar a formação de uma consciência política e racial. Esse não foi o primeiro artigo a abordar o fenômeno da Black Rio, como alega Vianna (1987, p. 57), mas foi a matéria que ganhou mais repercussão por conta da amplitude e profundidade com a qual tratou o tema.

$\mathrm{Na}$ esteira do artigo do Jornal do Brasil, vários outros jornalistas e críticos de esquerda de suplementos culturais tradicionais, revistas populares e jornais especializados em música logo amplificaram a crítica de Frias em relação à natureza comercial e importada do soul. Algumas semanas depois, 
Tárik de Souza (1976, p. 10), também do Jornal do Brasil, publicou o artigo intitulado "Soul: sociologia e mercado", em que comparava a história do jazz e da soul music nos EUA com as compilações e coletâneas brasileiras lançadas em vinil com o nome das equipes de som mais famosas e considerando essas gravações como " $10 \%$ de alma e $90 \%$ planejado marketing”. Além de criticar o soul como um movimento comercial, esses articulistas deixavam claras suas perspectivas, que evidenciavam a falta de vocação política e a inexistência de consciência racial entre os participantes da cena.

O questionamento à legitimidade do fenômeno e a ênfase em sua falta de expressão política estavam presentes também no desprezo em relação aos participantes. Para alguns jornalistas, o soul apenas demonstrava uma adesão a fórmulas musicais mercantis estrangeiras, e dificilmente poderia sugerir alguma coisa para além do mero conformismo de pessoas simples, despreparadas para resistir aos bombardeios de modismos propagados pelos meios de comunicação. (ALBERTO, 2009, p. 26) E mesmo reconhecendo uma motivação de protesto racial, José Ramos Tinhorão era enfático ao apontar a Black Rio como uma cópia, mas inadequada ao contexto brasileiro, enfatizando a questão da classe e da nacionalidade como fatores que deveriam prevalecer sobre a etnicidade na luta pelo fim da desigualdade social - e não racial:

[...] é que o grande desejo dos brasileiros de pele negra das grandes cidades (ao menos os do Rio e de São Paulo, onde o movimento black já existe) é parecer o mais possível com os negros norte-americanos. Isto é, deixarem de ser trabalhadores explorados num contexto subdesenvolvido, para se tornarem a imagem de trabalhadores explorados num contexto superdesenvolvido. (TINHORÃO, 1977, p. 2)

As acusações mais contundentes de inautenticidade do Black Soul vieram do jornal O Pasquim, representante máximo da esquerda alternativa na imprensa do período. O crítico musical Roberto Moura (1977, p. 2-8), no artigo "Carta aberta ao Black-Rio", descreve a cena do soul carioca como uma insidiosa campanha publicitária neocolonialista que visava simplesmente criar condições para o consumo dos excessos produzidos pela indústria cultural estrangeira, apontando para a falta de consciência política dos blacks, vistos 
como "não pensantes" e apenas preocupados com a aparência e os ditames da moda. ${ }^{3}$ Até mesmo o poeta Ferreira Gullar veio a público criticar o movimento, "negando significado sociológico ao black-jovem". De São Paulo, a voz do maestro Júlio Medaglia, um dos mentores musicais da Tropicália, também se levantou contra as influências estrangeiras da musicalidade americana, que poderiam macular a autêntica música afro-brasileira, em entrevista publicada na Folha de São Paulo em 10 de junho de 1977:

O que existe de mais trágico por trás de tudo isso é que eles estão tentando impingir um ritmo, uma harmonia e um som que nada têm a ver com a nossa musicalidade. E o pior é que estão se valendo de um bando de inocentes úteis, que mal sabem avaliar a importância do tesouro musical, que herdaram da África. (SANTOS, 1977, p. 32)

O compositor Caetano Veloso rebateu críticas a seus novos trabalhos, que consideravam que os artistas não poderiam se alienar da realidade e deveriam refletir em suas canções suas consciências políticas e seus desagravos em relação à repressão. O auge do patrulhamento aconteceu durante a turnê do álbum Bicho, quando o cantor se apresentou ao vivo acompanhado pela Banda Black Rio. A faixa de trabalho foi a composição "Odara”, que "apresentava bastante explícita a inspiração no funk, especialmente a forte presença do contrabaixo". (RODRIGUES, 2003, p. 37) O trabalho, que tinha uma proposta claramente voltada para a dança, foi duramente criticado pelas patrulhas ideológicas, visto como alienado. O LP Refavela (Philips, 1977), de Gilberto Gil, também foi criticado - chamado de "Rebobagem" pelo crítico Tárik de Souza na revista Veja.

O debate em torno das patrulhas ideológicas se refere a um momento muito particular dos anos 1970, em que intelectuais e formadores de esquerda deliberadamente passaram a cobrar uma arte engajada, criticando

3 Outro artigo do Pasquim, escrito por Aldir Blanc, intitulado "Safari", narrava a visita do jornalista a uma festa soul, comparando a experiência a uma caminhada pela África "desconhecida e escura", descrevendo os participantes como uma tribo liderada por um tirano, que falavam uma língua "estranha" intercalada com frases em inglês, como "oh yeah", e que adoravam os "deuses brancos do soul, os executivos das gravadoras". (O Pasquim, ago. 1977) 
manifestações que não se enquadrassem em um viés de contestação política. As patrulhas ideológicas estabeleciam claramente uma distinção de valor entre "músicas para dançar" e "músicas para pensar". Caetano denunciava os cadernos de cultura dos principais jornais e revistas do país, que seriam dominados por uma esquerda repressora representada por críticos que pretendiam policiar a música popular no Brasil. ${ }^{4}$ Se os próprios integrantes da MPB poderiam ser criticados por produzir canções e discos que privilegiassem a festa, a alegria, o ritmo e a dança, o que dirá de todo um movimento periférico, popular, baseado em bailes, nos quais se ouvia e se dançava música americana? Risério (1981, p. 32) ainda complementa: "Pior ainda é que esses setores supostamente 'progressistas' falavam em nome das massas oprimidas do país exatamente para condenar uma das manifestações estéticas e sociais mais vivas dessas mesmas massas oprimidas”.

A vida nas grandes cidades brasileiras foi marcada por movimentos jovens contraculturais, algumas vertentes diretamente descendentes do Tropicalismo, criado entre os anos de 1967 e 1968. De certa forma, por seu caráter mais fluido e sem uma ideologia consolidada nem preocupação diretamente política e institucional, esses movimentos eram vistos sem um claro propósito ideológico, muitos acusados de alienação política. Claramente, havia uma desilusão em relação às organizações tradicionais de esquerda, especialmente por esses centrarem o foco da revolução na classe, em detrimento de questões como raça e gênero, deixando de lado aspectos mais subjetivos. Novas demandas aparecem na esfera pública com o surgimento de movimentos sociais e políticos independentes representando negros, mulheres, gays e trabalhadores. O corpo e o físico natural, em um contexto pré-culto à boa forma dos anos 1980, era valorizado, acompanhando a liberdade das novas ideias e o fluxo mais livre do pensamento, o que não deixava de ser revolucionário e angariava mais adeptos que adotavam uma atitude contra a "caretice". Essa proposta de uma articulação política por outras vias que não a institucional nem por meio da luta armada ganhava fôlego, especialmente em um

4 Ver: Os críticos musicais, segundo Caetano Veloso, Jornal O Globo, Rio de Janeiro, 31 jan. 1979, p. 41. 
momento que marcava o fracasso das tentativas de revolução insurrecional durante o governo militar.

Mesmo alguns militantes, intelectuais e artistas negros viam com suspeição o Black Soul, temendo radicalizações e, mais ainda, o caráter comercial do movimento, o que não beneficiaria seus participantes negros e pobres. "Sinto que há uma tentativa de radicalização racial no Brasil. Acho que isso é uma jogada perigosa de grupos que estão estimulando o racismo como forma de planejamento de marketing para lançamento de linhas de produtos especificamente negros", comenta o publicitário negro José Jorge da Costa. (FRIAS, 1976, p. 5) O movimento estaria potencializando os lucros para empresários brancos, e não para a população negra. Apesar de diferenças ideológicas e de propósitos, Lena Frias atuava em um jornal vinculado à esquerda, como também era Abdias do Nascimento, famoso intelectual negro e ativista político. Embora o soul fosse reconhecido como um instrumento que favorecesse a união da comunidade negra na época, suas expressões estéticas e musicais eram vistas com certa desconfiança por alguns militantes negros que ainda separavam o estético do político. No entanto, essa visão aos poucos se modificou, a partir do momento em que essa produção cultural passou a ser vista de maneira positiva e incentivadora de uma mudança de comportamento frente à questão racial. (GOMES, 2006, p. 224) Em seu livro O genocídio do negro brasileiro (1979), Abdias critica a suposta alienação do soul, mas tenta identificar suas causas e relativizar seus efeitos a longo prazo. Para o intelectual, os blacks utilizavam símbolos e atos de consumo "alienados", mas que poderiam ter um valor positivo de afirmação racial e "espírito rebelde":

Essas realidades fazem compreensível que nas grandes cidades como o Rio de Janeiro e São Paulo a juventude negra canalize suas ansiedades para movimentos como estes, intitulados de 'Black Mad' ou de 'Soul' [...] os quais parecem utilizar a música, a dança, o vestuário, o corte de cabelo e outros símbolos como demonstrativos de inconformismo e confrontação. E também para evadir do sentimento de frustação, mesmo ao custo de recorrer a modelos alienados, cuja origem ostensiva são os negros dos Estados Unidos. Quem pode adivinhar se essa iniciativa, aparentemente equivocada, 
não se transformará num movimento de tomada de consciência e de uma afirmação original? (NASCIMENTO, 1978, p. 131)

Maria Motta-Maués (2009, p. 715) sinaliza que lideranças negras haviam incorporado a visão estereotipada da vocação e gosto atribuído às populações afro-brasileiras pelas festas e eventos de lazer. Especialmente militantes ligadas à imprensa negra e associações mais tradicionais consideravam como atividades políticas mais legítimas "reuniões, edição de jornais, manifestações públicas”, eventualmente saraus, cursos e outras ações educacionais, enquanto que as manifestações associadas à sociabilidade, a divertimentos, festas - que, inclusive, sempre estiveram presentes na história das entidades de movimento negro - eram vistos naquele momento como empecilhos à mobilização política e à conscientização racial por abrirem mão de uma ação pedagógica concreta. De certa forma, esse tipo de discurso das lideranças negras reproduzia um desejo de se desviar da imagem estereotipada dos negros como malandros, boêmios, bêbados, viciados, em prol da construção de uma imagem de honestidade, intelectualidade, respeitabilidade e de cumprimento dos deveres. Como Márcia Motta-Maués (2009, p. 719) considera, desde a década de 1930, havia uma continuidade no tratamento a determinadas manifestações populares, especialmente aquelas associadas a grupos negros populares, acusadas de serem perniciosas e de impedirem a elevação moral dos indivíduos - e essa era a intenção primordial dos primeiros movimentos negros.

Assim, o soul recebia uma dupla crítica: era tanto um "modismo" inútil, alienado e infértil de ideias, com uma inflexão deliberadamente comercial marcada pela importação de produtos culturais de uma América imperialista, como também representava uma "traição" ao patrimônio cultural brasileiro, pois seus participantes abraçavam o soul e deixavam de lado o samba, tido como a mais autêntica tradição afro-brasileira nacional. E esquerdistas tradicionais criticavam o Black Soul, alegando tratar-se de mero entretenimento, produzido e "commoditizado" pelo capital multinacional, que desviava a atenção da política de classes. (DUNN, 2009, p. 208) Vale notar que os blacks, naquele momento, recebiam críticas muito mais acirradas do que a juventude branca roqueira, influenciada, da mesma forma, por tendências 
americanas. Isso sugeria a escamoteação de um tom racista e discriminatório ao poupar dessas críticas as formas de lazer e consumo das elites e classes médias brancas, desmerecendo a Black Rio, esta usufruída por uma juventude negra menos privilegiada. Dom Filó, em entrevista à revista Veja, ofereceu uma resposta às críticas:

Por que se aceita com toda naturalidade que a juventude da zona sul se vista de jeans, dance o rock, frequente discoteca e cultue Mick Jagger, enquanto o negro da zona norte não pode se vestir colorido, dançar o soul e cultuar James Brown? Por que o negro tem que ser o último reduto da nacionalidade ou da pureza musical brasileira? Não será uma reação contra o fato de ele haver abandonado o morro? Contra uma eventual competição no mercado de trabalho? Por que o negro da zona norte deve aceitar que o branco da zona sul (ou da zona norte) venha lhe dizer o que é autêntico e próprio do negro brasileiro? Afinal, nós que somos negros brasileiros nunca nos interessamos em fixar o que é autêntico e próprio do branco brasileiro. (BLACK RIO, 1976, p. 158)

Para José Ramos Tinhorão, um dos mais ferrenhos críticos musicais e severo detrator da "americanização" da cultura brasileira, os discos de soul brasileiro lançados pelas gravadoras estrangeiras representadas pela WEA representariam uma "violência cultural consentida" e "exemplos de como a dominação econômica estrangeira, disfarçada por um desenvolvimento à base de importação maciça de capitais e tecnologia pode acarretar a contrapartida cultural de que, ser atual... é imitar o que se importa de mais moderno!”. Na crítica intitulada "Protesto ‘black' é fonte de renda ‘white”, Tinhorão (1977) considera esse um efeito da demanda de um novo mercado formado por consumidores negros em processo de ascensão socioeconômica diante de um maior acesso ao ensino superior por meio do crescimento da oferta de vagas em faculdades particulares, processo que ele compara à "expansão dos supermercados":

Levados normalmente a contestar as verdades oficiais vigentes, pela dificuldade que encontram em seu processo de ascensão em face 
da marca da cor, que os identifica tradicionalmente com as classes subjugadas (escravos até 1888, trabalhadores não qualificados depois), os brasileiros de pele escura dos grandes centros urbanos foram levados a projetar-se na imagem das camadas equivalentes nos Estados Unidos. E, assim - inspirados pelas sugestões dos filmes de cinema e de televisão, pelas reportagens de revistas e pelas novidades musicais - inclinaram-se não a tomar consciência da sua realidade de trabalhadores brasileiros freados em seus propósitos de melhorias de vida pela barreira da cor, mas a imitar os processos de luta criados pelos negros americanos: a contestação pela extravagância, o orgulho pessoal, a formação de núcleos próprios etc. Mas tudo isto, apenas - e que é revelador da falta de sentido critico ideológico do seu movimento - apenas na área do lazer. (TINHORÃO, 1977, p. 2)

Da sua maneira, Tinhorão (1977) representava a visão da esquerda de que a Black Rio era uma questão de comércio, consumo e "indústria do lazer", que dissolvia reivindicações e pautas políticas em favor da diversão e da moda. Os negros brasileiros seriam, pois, inconscientes em seu desejo de se parecer com os negros norte-americanos - "Isto é, deixarem de ser trabalhadores explorados num contexto subdesenvolvido, para se tornarem a imagem de trabalhadores explorados num contexto superdesenvolvido". O crítico também apontava a questão da classe como superior às ações baseadas na raça ou na cultura. Foram os críticos culturais que ajudaram a difundir a expressão “vazio cultural”, que estigmatizou os anos 1970 como um período de suposta inatividade, "desbunde" e ausência de produções artísticas de cunho mais flagrantemente político. Bahiana (1980, p. 42) enumera algumas razões para esse "esvaziamento", que teria levado o público jovem a se voltar para o consumo descompromissado da música internacional: o clima repressivo da ditadura - que se aprofundou entre 1969 e 1975 -, a saturação da fórmula dos festivais, a prisão e exílio compulsório de intelectuais e artistas de esquerda, que acompanharia o desejo das novas gerações de "admirar e, consequentemente, tentar imitar com fidelidade a música que vinha de fora”.

Por volta de 1972, a fase mais repressiva do governo militar, a oposição armada foi, em grande parte, reprimida, com a prisão e exílio de muitos 
ativistas políticos. A agitação cultural do final da década de 1960 foi substituída por uma atmosfera de desilusão política, e os problemas sociais e econômicos se agravaram. "Com quase todas as vias de oposição política organizada bloqueadas, a juventude urbana da classe média se voltou para buscas mais pessoais e espirituais” (DUNN, 2009, p. 198), tendência que se mostrava predominante em várias cidades do mundo, condicionando a emergência de uma série de movimentos contraculturais. Essa nova inclinação contracultural no Brasil ganhou o sobrenome de "desbunde" pela esquerda tradicional. O termo jocoso correspondia ao ressurgimento de controvérsias públicas entre vários setores da oposição a respeito do papel dos artistas e intelectuais, em um questionamento da eficácia social e política da arte e da cultura. Foi o momento do surgimento das patrulhas ideológicas ligadas a críticos e militantes ortodoxos de esquerda. Para estes, em um momento de desesperança e desilusão diante da manutenção do regime com guerrilhas, torturas, sequestros e assassinatos, quaisquer produtos culturais que ousassem investir em discursos positivos sobre a realidade, exaltando a alegria, ou que se voltassem para o simples hedonismo festivo, eram imediatamente taxados de "entreguistas", "alienados" e até "colaboradores do regime" - como ocorreu com Wilson Simonal. Muitos artistas, não apenas da música, como também do cinema, literatura e teatro, ansiavam por mais autonomia artística e buscavam discutir outros temas, o que soava como alienação para os "patrulheiros", visto que essas visões mais otimistas e descompromissadas com a política não poderiam ser imediatamente identificados com uma "resistência".

Para Cunha (2009, p. 82), esses fatores que determinaram o esvaziamento também seriam os mesmos que ofereceram novas matérias-primas para diferentes maneiras de atualização cultural, novas demandas sociais e visões alternativas. Novos artistas e movimentos começaram a surgir questionando a autoridade intelectual da esquerda e denunciando seus privilégios enquanto representantes de minorias. Esses grupos não se sentiam representados por essas organizações tradicionais e passaram a produzir seus próprios repertórios de modas e linguagens locais, no ímpeto de criar diferentes maneiras de "estar no mundo" e de fazer política, para além das bases institucionais, buscando possíveis transformações no espaço do cotidiano. 
Mesmo sambistas negros criticavam o movimento pela sua falta de autenticidade cultural, já que o funk representava, para esse grupo, uma corrupção das tradições do samba. Essa rivalidade, incentivada e explorada pela mídia e gravadoras, basicamente foi encabeçada por Candeia, compositor criador da escola de samba Grêmio Recreativo de Artes Negras Quilombo, ${ }^{5}$ em 1975, que tinha uma atuação importante em relação à pesquisa e valorização das tradições musicais negras do Rio de Janeiro. O compositor chegou a declarar: "Não tememos a incompreensão de muitos, as calúnias de outros e nem as queixas de negros racistas”. (CANDEIA..., 1978, p. 135) Em 1977, gravou, com Dona Ivone Lara, o partido alto "Sou mais o samba": "Eu não sou africano, nem norte-americano/ ao som da viola e pandeiro/ sou mais o samba brasileiro”. Segundo Dom Filó, em entrevista a Essinger (2005, p. 41), isso foi uma estratégia de marketing da própria WEA, que era contratante tanto de Candeia quanto da SGP, como forma de criar polêmica e chamar a atenção para seus artistas. Mas frequentadores e fãs do samba e do Black Soul trocavam críticas efetivamente:

adeptos da música 'soul' afirmam ter desistido de ir às quadras de escolas de samba porque estas se haviam comercializado em demasia; sambistas consideram ser o 'Black Rio' um fenômeno eminentemente comercial e, por conseguinte de pouca qualidade". (CAVALCANTI, 1981, p. 16)

A leitora Rosa Nascimento, em carta enviada ao Jornal do Brasil em 22 de julho de 1977, denunciava o tratamento recebido pela Banda Black Rio na quadra da escola de samba Quilombo, em um evento voltado para festas populares. O grupo teria sido impedido de se apresentar pelos dirigentes da agremiação, que alegavam "preservar e divulgar as origens das manifestações artísticas populares".

5 O Grêmio Recreativo de Arte Negra e Escola de Samba Quilombo foi fundado pelos compositores Candeia, Nei Lopes, Wilson Moreira e Mestre Darcy do Jongo em 8 de dezembro de 1975, na Fazenda Botafogo, subúrbio do Rio de Janeiro. A escola de samba nunca foi filiada a nenhuma liga carnavalesca e não participa de desfiles competitivos. Suas atividades de resgate dos valores originais do samba incluem trabalhos culturais e sociais, especialmente voltados para a comunidade negra e pobre da região. 
Temendo a repressão, alguns DJs e equipes evitavam assumir posições políticas, garantindo que seus negócios tinham um mote apenas de entretenimento. A Lei de Segurança Nacional previa pena de detenção de um a três anos para quem incitasse publicamente ao ódio e à discriminação racial. (BRASIL, 1967, Art. 33, VI) Nirto, um dos donos da SGP, se defendia:

Você viu? Aquele festival de rock em Saquarema reuniu umas $30 \mathrm{mil}$ pessoas e não houve nenhuma restrição a nada. Então, poderíamos dizer também que está havendo movimento político no rock. E não está havendo. Não é nada disso. Simplesmente o rock, atualmente no Brasil, reúne mais pessoas brancas. Agora, o soul não; o soul atinge mais as pessoas negras. Este é o motivo de o soul reunir tantos negros, tantos blacks no Brasil. (FRIAS, 1976, p. 4)

Além disso, as equipes e os frequentadores começaram a ser considerados racista em relação aos brancos, pois existiam histórias de brancos barrados nos bailes soul. "O racismo começou com a Soul Grand Prix", afirmou Big Boy, na época (FRIAS, 1976, p. 5), ${ }^{6}$ corroborando a crença de que a discriminação e o preconceito racial poderiam ser acionados pelos negros mais radicais em relação aos brancos. Essa tese, como notaremos a seguir, também estava presente nas suspeitas da polícia secreta, que temia um clima de animosidade racial provocado pelos bailes black. Essas críticas eram questionadas por DJs como Mr. Funky Santos, que também não assumia a existência de um problema racial no Brasil, nem dava um tom político aos seus bailes:

Eu não acho que o soul Power seja um movimento racista. Porque eu acho que esse é um país onde a gente não deve implantar esse tipo de coisa, porque aqui, seja branco, seja negro, a gente deve estar lado a lado. Há aquelas barreirinhas, mas são muito pequenas. Então, se a gente for implantar um movimento desses, a gente está arriscando a se quebrar. Não é uma boa, eu não aconselho ninguém a fazer. Porque o soul é o caminho da comunicação entre os negros. Não é

6 Big Boy também afirma na mesma reportagem sua perda de mercado: "Atualmente, a Soul Grand Prix, que não tem a metade do material que eu tenho, ganha $\mathrm{Cr} \$ 10$ mil por baile. Eu ganho Cr\$ 5 mil”. (FRIAS, 1976, p. 5) 
um movimento negro. É um movimento de negros. (MR. FUNKY SANTOS, 1976, p. 4)

Ao enfatizar os bailes black como canais de comunicação entre negros, Mr. Funky sinaliza para o potencial político e de mediatização dessa cena musical, mas sem reconhecê-la como uma organização coletiva efetiva, com lideranças e pautas definidas. Havia sim uma finalidade política, quando os bailes de soul se tornam "um meio para atingir um fim - a superação do racismo”, como considera Vianna (1987, p. 57), mas que se consolidava na oferta de novos repertórios simbólicos e culturais que ressaltavam a capacidade de intervenção de seus atores sociais, propondo novas implicações para as políticas culturais brasileiras. Esse potencial foi reconhecido, apoiado e defendido pelas novas entidades do movimento negro da época, como o então recém-criado IPCN em 1976, que apoiava os blacks e cujos dirigentes mantinham estreita relação com a cena do soul. Carlos Alberto Medeiros, membro da diretoria do instituto, escreveu um editorial no Jornal da Música em agosto de 1977 defendendo a Black Rio:

É claro que dançar soul e usar roupas, penteados e cumprimentos próprios não resolve, por si, o problema básico de ninguém. Mas pode proporcionar a necessária emulação - a partir da recriação da identidade negra perdida com a Diáspora Africana e subsequente massacre escravistas e racistas - para que se unam e, juntos, superem suas dificuldades.

\section{Direita, ditadura e repressão}

As críticas ao soul partiam também de jornais considerados de direita, como O Globo. Em 26 de abril de 1977, na página dez da edição matutina, um editorial não assinado declarava o posicionamento do jornal:

É próprio da juventude escolher os seus próprios meios de expressão; e é comum que esses meios sejam esdrúxulos, excêntricos. Assim, não é por seus aspectos pitorescos, beirando às vezes o grotesco, que se deve condenar esse movimento batizado de 'soul', ou, na 
versão carioca, de ‘Black Rio’. O problema não está nas roupas, nos sapatos ou nos apelidos. Mas está no que esconde atrás de tudo isso: uma visão alienada da realidade, artificialmente estimulada por interesses nitidamente comerciais, e tendo por base um indisfarçado racismo [...]. Não se pode considerar autêntico, nem positivo qualquer movimento - musical, esportivo ou que outro pretexto tenha - que, em nome de uma manifestação artística, ou mesmo de simples entretenimento, procure dividir a sociedade brasileira com uma cunha [sic] racial. (RACISMO, 1977, p. 10)

Críticos conservadores aliados ao regime militar, como Gilberto Freyre, ${ }^{7}$ atacavam o movimento soul dizendo tratar-se de mera importação insidiosa dos discursos culturais e políticos afro-americanos irrelevantes para a "democracia racial” no Brasil. Em artigo intitulado “Atenção brasileiros”, publicado no Diário de Pernambuco em 16 de maio de 1977 e repercutido no Jornal do Brasil no dia seguinte, Freyre critica a articulação da afirmação racial com o marxismo, em uma militância que poderia provocar “ódios”, mas também conjuga duas formas de imperialismo que poderiam agir sobre o Brasil por meio desse movimento: o norte-americano capitalista e o soviético comunista. Ou seja, em uma intrincada perspectiva irrealista, Freyre considerava que duas forças historicamente antagônicas estariam se unindo e utilizando a juventude black da época como ferramenta de dominação do país.

Teriam os meus olhos me enganado? Ou realmente li que, dos Estados Unidos, estariam chegando ao Brasil - se é que já não se encontram - vindos da tradicionalmente muito amiga República dos Estados Unidos da América do Norte - por quem? - de convencer brasileiros, também de cor, que suas danças e seus cantos afro-brasileiros deveriam ser de melancolia e de revolta? [...] Se é verdade o que suponho ter lido' - escreve o autor de Casa Grande e Senzala - 'trata-se de mais uma tentativa da mesma origem no sentido de

7 É notório que Gilberto Freyre era um entusiasta do movimento militar de 1964, tendo sido convidado pelo marechal Castelo Branco a assumir o Ministério da Educação e colaborando com o regime nas perseguições a intelectuais. Para mais, ver: Gilberto Freyre: um vitoriano nos trópicos, de Maria Lúcia Garcia Pallares-Burke (2005). 
introduzir-se num Brasil crescentemente, fraternalmente, brasileiramente moreno - o que parece causar inveja a nações também bi ou tri-racionais nas suas bases - o mito de uma negritude, não a la Senghor, de justa valorização de valores negros ou africanos, mas que faria às vezes daquela luta de classes tida por instrumento de guerra civil. (SOCIÓLOGO..., 1977, p. 14)

Para Alberto (2009, p. 28), as críticas por parte da imprensa em geral acabaram por chamar a atenção também da ditadura, que passou a investigar bailes, DJs e produtores - apesar de que o DGIE, órgão de inteligência da polícia, havia começado suas investigações em abril de 1975, portanto, antes do artigo de Frias ter sido publicado. Essas reportagens serviram de suporte para embasar justificativas de investigação e a polícia secreta do regime começou a acompanhar as movimentações, com receio de estar sendo implantada no Brasil uma célula subversiva dos Panteras Negras ou de outros movimentos negros radicais norte-americanos. Os Panteras Negras (Black Panther Party for Self-Defense) foi um partido e organização fundado em 1966 por Bobby Seale e Huey Newton, inicialmente baseado em projetos sociais e educacionais voltados para a comunidade negra e para as crianças. Com o acirramento das tensões raciais, seus integrantes passaram a ser reprimidos pela polícia e logo estabeleceram táticas para se opor à violência do Estado, defendendo ações armadas em defesa da causa negra. ${ }^{8}$ Mas também apoiavam outras pautas ligadas a minorias como o movimento do Orgulho Gay, sendo os primeiros a endossá-lo. A imagem dos Panteras Negras despertava receio entre as autoridades brasileiras, pois a criação de um movimento com inspirações semelhantes no Brasil representava uma ameaça à propaganda e à comunicação oficial do governo militar, que tentava difundir uma imagem e um sentimento de união nacional, evitando qualquer referência a uma possível desarmonia racial, dentro ou fora do país. Isso valia também para imagens do cinema, e, segundo Hanchard (2001, p. 137), os censores foram instruídos a proibir quaisquer filmes que retratassem problemas raciais no Brasil ou

8 Autores como James Baldwin, de Numa terra estranha (1963), e Eldridge Cleaver, de Alma no exílio (1971), forneceram as bases filosóficas para a formação do grupo Panteras Negras. 
nos EUA, especialmente aqueles que abordavam diretamente o movimento Black Power. $^{9}$

Efetivamente, a ditadura já vinha exercendo repressão policial sobre outras manifestações de cunho artístico ou musical que tivessem relação com quaisquer protestos raciais. Em 1971, no VI FIC, realizado no Maracanãzinho, Tony Tornado e Elis Regina apresentaram a música "Black is beautiful”, composta pelos irmãos Marcos e Paulo Sérgio Valle. A composição, por si só, já havia sido censurada antes do lançamento. A letra original, segundo Palombini (2009), continha os versos "eu quero uma dama de cor / uma deusa do Congo ou daqui / que melhore o meu sangue europeu” foi substituída por "Eu quero um homem de cor / um deus negro do Congo ou daqui / que se integre no meu sangue europeu”, tanto para se adequar ao eu-lírico feminino na voz de Elis quanto para garantir que a herança europeia e negra fossem "igualadas" em termos de valor e importância, mantendo o ideal positivo da mestiçagem e da integração racial. Mesmo assim, a apresentação da canção ainda gerou polêmica e, durante a apresentação no festival, Tony Tornado levantou uma das mãos com o punho cerrado, gesto característico dos Panteras Negras, e acabou sendo preso ainda no ginásio. (PELEGRINI; ALVES, 2011)

Mas, inicialmente, a vigilância sobre os bailes tinha uma motivação de manutenção da "ordem e segurança pública", e era comum a revista a sacolas de disco em busca de drogas, quando os policiais chegavam ao absurdo de revistar o cabelo black dos frequentadores negros dos bailes (MARSIGLIA, 2015; PEREIRA, 2000), inclusive confiscando pentes-garfo, pois achavam que os dentes de metal poderiam ser usados como armas. (PIRES, 2015, p. 19) Se algum jovem negro fosse preso, via de regra, teria seu cabelo raspado. $\mathrm{O}$ policiamento, nesse caso, não era apenas sobre o caráter de mobilização política ou ação subversiva, mas também se referia à própria repressão institucional que faz parte da história da sociedade brasileira desde os tempos da

9 Hanchard (2001, p. 137) cita como exemplo de censura que representava a preocupação quase paranoica de se evitar qualquer discussão racial o caso de uma frase cortada de um artigo traduzido do jornal britânico Manchester Guardian sobre xadrez, que dizia: "Os brancos têm grandes vantagens materiais, enquanto os negros quase não têm abertura legal”. 
escravidão, em que o "elemento negro" e suas manifestações culturais eram vistos com suspeição pelas autoridades.

Quantas vezes já corri de pancadaria e invasões da polícia nos bailes do Greipe da Penha e também em Madureira, Marechal Hermes, Rocha Miranda. Umas duas vezes a polícia deu tiros dentro do clube Greipe para acabar com o baile. E se você fosse preso, tomava porrada e ainda te esculachavam. Um amigo meu, lá de Padre Miguel, que ia sempre aos bailes comigo e uma galera, foi preso e tosaram a cabeleira black power dele e feriram o couro cabeludo. (Ras Adauto)

Recentemente, em julho de 2015, a Comissão Estadual da Verdade do Rio de Janeiro (CEV-RJ) encontrou documentos que mostram como, a serviço da ditadura, investigadores passaram a vigiar artistas e produtores dos bailes com a suspeita de que um revolucionário afro-americano estaria no Brasil recrutando militantes para implementar no país um regime de segregação racial. ${ }^{10}$ A reportagem sobre a descoberta foi publicada no jornal $O$ Globo em 11 de julho de 2015, de autoria de Flávia Oliveira, que diz que o ponto de partida dos historiadores da CEV-RJ foi um informe de fevereiro de 1975, enviado pelo I Exército aos órgãos de informação, incluindo o Dops do antigo estado da Guanabara. No relatório intitulado Black Power (Informe 17/75-B), havia um alerta sobre a formação de um grupo de jovens negros " [...] de nível intelectual acima da média, com pretensões de criar no Brasil um clima de luta racial”. (OLIVEIRA, 2015) Eles estariam recebendo instruções e financiamento do exterior, e o local dos encontros era na quadra da escola de samba Portela.

O relatório também descrevia supostos objetivos do grupo: "Sequestrar filhos de industriais brancos; criar um bairro só de negros; criar ambiente de aversão aos brancos". Pelas informações contidas nos relatórios, as investigações eram conduzidas por policiais negros, que poderiam se infiltrar discretamente nos bailes sem causar maiores suspeitas. Mesmo sem conseguir

10 Ainda que a repressão sobre as escolas de samba não tenha começado com a ditadura, a censura e a repressão do regime militar também foram aplicadas às escolas de samba, segundo Hanchard (2001, p. 138): "era comum a polícia invadir as quadras de escolas de samba, nessa época, e fazer detenções indiscriminadas de até duzentos rapazes negros de cada vez, bem no meio da quadra". 
comprovar as denúncias, os relatórios serviram como justificativa para a perseguição aos organizadores dos bailes - equipes de som como Black Power e SGP e seus integrantes eram nominalmente citados. Os textos ainda traziam descrições detalhadas do público presente aos bailes, valor dos ingressos e até expressões usadas pelos frequentadores - ao $2^{\circ}$ Encontro dos Blacks, no Portelão, compareceram 6 mil "pessoas de cor", segundo o documento da Seção de Buscas Ostensivas.

Os responsáveis pelos bailes foram fichados e interrogados. Em 1976, Asfilófio de Oliveira Filho, o Dom Filó, da Soul Grand Prix, foi capturado perto do Renascença Clube, na saída da Noite do Shaft. Encapuzado, foi lançado num carro. Terminou numa sala úmida, com a visão ofuscada por uma luz forte. Passou a madrugada sob tortura psicológica, sem saber onde estava. A descrição do ambiente coincide com depoimentos de presos políticos que passaram pelo DOI-Codi, cuja sede ficava no Quartel do $1^{\circ}$ Batalhão da Polícia do Exército, na Rua Barão de Mesquita, na Tijuca. 'As vozes perguntavam onde estava o US\$ 1 milhão. Mas aquilo não existia', lembra Dom Filó, deixado horas depois no Lins de Vasconcelos. (OLIVEIRA, 2015)

O primo de Filó, Nirto, também foi detido e interrogado, na tentativa da polícia de confirmar a suspeita de que americanos estariam financiando o movimento. E começou-se a notar uma vigilância mais ostensiva dos bailes, com agentes infiltrados nas festas e até mesmo tentativas de forjamento de flagrantes de tráfico de drogas no escritório da equipe SGP, localizado na Central do Brasil, mas sem sucesso: "O esperto que tentou armar a tramoia acabou sendo desmascarado e, de forma cinematográfica, pendurado na janela do $23^{\circ}$ andar para confessar", conta Essinger (2005, p. 35). O cantor Gerson King Combo também foi detido, levado para a sede da Polícia Federal na Praça Mauá, Centro do Rio, e interrogado durante três horas, após desembarcar de um voo no aeroporto Santos Dummont. Ele era considerado pela polícia como "líder do movimento black". ${ }^{11}$ De fato, essa opinião era

11 Em entrevista a Moraes (2014, p. 27), o produtor e empresário de Gerson King Combo conta que sempre havia alguém da produção vigiando os bailes para dar o alerta caso a polícia apare- 
compartilhada com alguns veículos da imprensa, como O Globo. Em um editorial intitulado "Black Power in Brasil", o articulista Ibraim De Leve - provavelmente um pseudônimo para o colunista social Ibrahim Sued, já que a "de leve" foi uma expressão criada e frequentemente utilizada por ele - denuncia que um grupo não identificado estaria tentando deslanchar no país um movimento Black Power organizado e afirma: "O líder é o cantor Gerson King Gomho, e o vice-líder é Tony Tornado. O objetivo do movimento é instaurar o racismo nesse país, como existe nos Estados Unidos”. (DE LEVE, 1977) E segue denunciando que, nos bailes, os negros geram agitações e estimulam o confronto contra brancos, insuflando uma revolta racial no país. Esse temor tinha relação com a ideia de que o soul seria uma célula de esquerda, comunista e da "resistência".

Tony Tornado também era alvo das críticas da esquerda por seu canto "americanizado" e o acusavam de copiar a música estrangeira (ALONSO, 2011, p. 123), debochando de seu estilo que mimetizava James Brown. De certa forma, como considera Alonso (2011, p. 124), mesmo que Tony Tornado e, por conseguinte, Gerson King Combo e outros cantores brasileiros de soul compusessem e gravassem músicas que pregassem o protesto e a conscientização, nunca foram considerados artistas da "resistência", pois eram criticados de serem "copiadores" de uma musicalidade "importada”, portanto, alienada e menos legítima. O próprio Tim Maia, reconhecidamente influenciado pela música americana, disparou:

Faço música de preto. E os pretos precisam se convencer de que chegaram ao mundo dos brancos acidentalmente, em navios negreiros. Olha só isso que chamam de movimento Black Rio: os negros não passam de xerox dos americanos, que, por sua vez, imitam os brancos. Não sacam que o negócio é voltar para a África. (MOTTA, 2006, p. 127)

André Midani, presidente da WEA, que possuía vários artistas e equipes de soul em seu cast, veio em defesa dos blacks, se posicionando contra as

cesse, a fim de que pudessem esconder os discos de soul imediatamente, trocando as músicas e passando a tocar samba para disfarçar. 
críticas da "imprensa branca" que os acusavam de perda da negritude, representado pela rejeição ao samba. Em 1985, em entrevista ao Jornal do Brasil, Midani reafirma sua postura:

Eles congelam os negros como responsáveis por guardar a cultura brasileira intacta através dos anos. E no meu entender, isso é perigoso porque impede o negro de entrar na sala de jantar. Ele não tem o direito aos instrumentos eletrônicos, nem de usar e abusar das aventuras que a modernidade pode proporcionar a sua linguagem musical. (CARONE, 1985)

Midani ainda conta que, devido a comentários como esse, seu nome chegou ao Ministério da Justiça, apontado como receptor de fundos do movimento black americano, que estavam sendo utilizados para financiar uma guerrilha urbana a partir das favelas, mas o assunto não teve maiores consequências. O disco-jóquei Mounsieur Limá, que também estava lucrando bastante com o movimento e realizando concorridos bailes, defendia o fenômeno, não enfatizando sua autenticidade, mas realçando sua capacidade de "controle social”, garantindo a segurança na cidade, que deveria ser incentivado pelo governo: "Se não houvesse isso, eu garanto que haveria um aumento grande nos assaltos, nos finais de semana, o pessoal sem ter o que fazer, sem ter como se divertir”. (O SOUL..., 1976, p. 5) Apesar de não mencionar diretamente a juventude negra como alvo principal do comentário, o DJ ressaltou dois estereótipos clássicos relacionados ao negro, especialmente pobre, que é aquele que ou dança ou é criminoso. ${ }^{12}$

Mesmo com esses argumentos não tão enaltecedores, as investigações policiais continuaram e se estenderam a São Paulo e ao Rio Grande do Sul, cujos escritórios da Polícia Federal produziram relatórios com um mote comum: todas as investigações criminalizavam o movimento black e o acusavam de pregar entre jovens negros "o preconceito racial, a discórdia e o desentendimento nocivo à comunidade brasileira”. Havia também uma preocupação tácita em buscar conexões dos integrantes mais famosos com organizações

12 E, de fato, como defende Vianna (1988), era notória a ausência de álcool e drogas mais pesadas, bem como de graves atos de violência nos bailes de soul. 
comunistas, citando nominalmente Monsieur Limá, Tony Tornado, Big Boy, Ademir Lemos e membros das equipes, além de jornalistas como Tárik de Sousa, Lena Frias, Tarlis Batista, além do fotógrafo Almir Veiga. A repressão também recaiu sobre a questão administrativa das equipes, as movimentações financeiras, valores de ingresso, fluxo de caixa, segundo depoimento do professor da Universidade Federal Rural do Rio de Janeiro (UFRRJ), Pereira Amauri, ao programa Caminhos da Reportagem em 2014.

Em 1976, um documento de investigação policial que anexava reportagens como a de Lena Frias registrava a declaração de que o soul "explorava, de certa forma, o orgulho da negritude, o confronto entre brancos e pretos, e as rivalidades sociais e econômicas entre a Zona Norte e a Zona Sul do Rio de Janeiro". (ALBERTO, 2009, p. 28) Havia ainda nos relatórios a denúncia de que alguns bailes não aceitavam a entrada de brancos, como os da equipe Black Power - e que, por isso, havia sido banida do Grêmio Recreativo Rocha Miranda -, o que incorreria, tecnicamente, em um crime de discriminação racial, violando a lei Afonso Arinos de 1951, mas o que não gerou maiores repressões ou processos policiais contra os organizadores desses bailes. De qualquer forma, mesmo com a presença nos relatórios de denúncias de "radicalismos" nos bailes que proibiam ou dificultavam a entrada de brancos, alguns investigadores consideravam essa atitude um reflexo de práticas semelhantes em clubes de rock ou clubes sociais, como o late Clube do Rio de Janeiro, Hípico Brasileiro, o Clube Militar, frequentados por brancos na Zona Sul, que rotineiramente faziam a mesma coisa com indivíduos negros. (ALBERTO, 2009, p. 11)

Apesar das intensas investigações, não houve qualquer conexão mais forte com organizações comunistas ou grupos negros radicais americanos, e os investigadores passaram a focar nas implicações psicossociais do movimento, adotando a visão esquerdista de que os bailes de soul tinham apenas uma preocupação mercadológica, visto que a maioria dos organizadores e das equipes não fazia distinções em relação aos "tipos étnicos” dos frequentadores. Mas a pesquisa dos arquivos do DGIE por Pires (2015, p. 43) relata que não foi possível corroborar nenhuma das suspeitas da repressão, como a implicação de capital e membros estrangeiros no movimento do soul; a presença de atos contra brancos ou maiores animosidades raciais; o uso de drogas nos 
bailes; a crítica direta ao regime ou a presença de propaganda comunista, entre outros. E entre os meses de outubro e novembro de 1976, o DGIE encerrou as investigações.

O relatório da polícia que encerrou as investigações sobre o soul ecoou ainda mais a linguagem dos comentaristas da esquerda. Ele não apenas concluiu que qualquer confronto entre negros e brancos brasileiros era, em última análise, uma questão de música, moda e marketing, ao invés de uma consciência política, como também traduzia o pesar da esquerda de que o soul havia transformado uma real consciência revolucionária em uma espécie de alívio complacente, e que os seus frequentadores nunca teriam sido capazes de constituir uma ameaça real para o governo. (ALBERTO, 2009, p. 30)

A polícia finalmente percebeu que os bailes black eram apenas uma tentativa de reunir um grupo específico em torno de uma forma particular de música, estilo e lazer, mas ressaltando ainda uma distinção clara, presente em alguns pontos dos relatórios, que separava os frequentadores gerais, chamados de "pessoas de cor", daqueles que seriam mais engajados, considerados mentores desse movimento, os "negros" ou "blacks". De certa forma, um passo além da crítica produzida pela esquerda, pois sugeriam uma noção de diferença política fundamental entre a constituição de identidades locais difusas e a de identidades definidas a partir da importação de símbolos culturais internacionais (ALBERTO, 2009, p. 12), que no espaço dos bailes entravam em disputa na conformação de estilos particulares e diferentes. Mas a repressão assustou muitos donos de equipes, que ou modificaram paulatinamente o som de seus bailes, adotando sonoridades menos conectadas a uma sensibilidade black, passando a investir mais na disco music e no pop-rock, ou simplesmente abandonaram o negócio das festas.

\section{O fim dos bailes?}

Alguns autores, como Essinger (2005), Giacomini (2006), Mccann (2002), Thayer (2006) e Ribeiro (2008), consideram que a cena Black Rio começa a entrar em declínio no final dos anos 1970, por conta de fatores como a 
atenção negativa gerada pelas reportagens jornalísticas e a repressão da polícia da ditadura; críticas por parte da esquerda e de artistas ligados ao mundo do samba; e a introdução da disco music no mercado musical. A respeito da suposta definitiva substituição do soul pela disco, ${ }^{13}$ tanto nas gravadoras quanto no gosto dos públicos dos bailes, há algumas particularidades que dão a entender que, por um tempo, os dois gêneros conviveram, dividindo espaços e profissionais. Muitas equipes aderiram à disco, especialmente aquelas que não tinham uma preocupação mais clara com a questão racial e começaram a realizar bailes com vistas apenas na lucratividade. Isso não deixou de criar uma situação inédita, pois "a Zona Sul e a Zona Norte estavam dançando as mesmas músicas”. (VIANNA, 1987, p. 61) Com uma divulgação maciça pelas gravadoras, a disco music ainda foi tema de uma novela de enorme sucesso, Dancin' Days (1978-1979), que, ao lado do filme Os embalos de sábado à noite (1977), ajudou a difundir a moda da discoteca e tomou o espaço do soul na mídia e no gosto do público. A era disco teve uma duração curta, mas foi o suficiente para desarticular a cena black, e os bailes de soul voltaram a acontecer somente na periferia, em menor número. O segmento na indústria fonográfica também logo foi ocupado pela disco music e, depois, pelo rock e pelo pop, tanto nacional quanto internacional.

Os bailes black passaram a não ser mais tão concorridos, a exemplo do que ocorreu com a SGP. A equipe passou a ocupar tocar apenas em uma noite por semana, aos domingos, no Clube Condomínio, no bairro do Jardim Botânico, Zona Sul do Rio, eventualmente realizando bailes na Zona Norte, frequentemente dividindo espaço com outras equipes. A SGP também enfrentava problemas financeiros. Vianna (1987, p. 61) conta que a equipe trouxe para o Brasil o grupo norte-americano Archie Bell and The Drells, ligado ao Philly Soul, para realizar 17 apresentações junto com a equipe. O conjunto ganharia 10 mil dólares, "livres de despesas", por apresentação (FRIAS, 1976, p. 1), uma quantia vultosa para a época, mas a turnê foi um fracasso. ${ }^{14}$

13 Para saber mais sobre a ascensão da disco music no Brasil, ver: Essinger (2005) e Rodrigues (2003).

14 Segundo Frias (1976, p. 3), havia um projeto de trazer outros artistas da Philadelphia International Records para o Rio de Janeiro, empresariados por uma firma paulista, a Four Seasons, que acabou não se concretizando. 
Com o enorme prejuízo, a equipe foi obrigada a vender parte de seu equipamento de som para pagar as dívidas e passou também a realizar bailes de disco music, gerando desavenças entre a equipe e a saída de Dom Filó, que foi estudar nos EUA e retornou anos depois, criando com Carlos Alberto Medeiros uma produtora de vídeo. No entanto, até o começo da década de 1980, discos de soul ainda eram lançados, como as coletâneas assinadas por Mr. Funky Santos, mas já considerados uma espécie de flashback, rótulo logo associado aos bailes que continuaram tocando soul após os anos 1970 - em São Paulo, são chamados de festas "nostalgia" e também tocam clássicos do samba-rock.

Para alguns participantes do movimento, a superexposição da Black Rio na mídia e no mercado musical acabou por colaborar para sua decadência. A saturação acabou sendo inevitável, e o público se voltou para outras novidades. Alguns setores da imprensa e da esquerda mantinham constantes ataques ao caráter "mercantilista" dos bailes e das equipes, enquanto intelectuais e sambistas denunciavam os participantes da cena como "colonizados", "imitadores", que estariam colocando o samba e a cultura nacional em perigo. A TV também ajudou tanto na divulgação do movimento quanto na propagação de imagens e ideias associadas aos blacks que não colaboravam para uma visão positiva da Black Rio, especialmente quando sátiras passaram a ser feitas, a exemplo dos humoristas Os Trapalhões, cujos esquetes ajudaram a estigmatizar os blacks. Mas, mesmo que o contato e as negociações entre o movimento black e a mídia, a moda e o mercado pudessem repotencializar suas políticas de estilo na cultura da época, favorecendo novos diálogos e apropriações, o fato é que parece ter havido uma saturação do soul, especialmente em relação ao mercado musical.

Em declaração à revista Veja, Marco Mazola, da WEA, explicou que as leis de marketing da indústria do disco preconizam que as grandes vendas de discos "[...] dependem menos dos valores individuais do que das correntes e movimentos musicais”. (BLACK RIO, 1976, p. 156) Daí o investimento da gravadora no movimento Black Rio como forma de alavancar uma maior lucratividade. Mas, como qualquer "movimento", ele é provisório e se baseia em ciclos que se extinguem de acordo com o surgimento de novas tendências. Os inúmeros artistas brasileiros de soul foram deixando de gravar discos ou tiveram que se adaptar, se engajando em outros gêneros musicais depois 
que seus álbuns não mais alcançaram o sucesso de vendas esperado, em parte porque "a sonoridade dos arranjos nacionais (com exceção de Tim Maia) não agradaram aos dançarinos cariocas”, como justifica Vianna (1987, p. 60). Na verdade, os discos de soul brasileiro não agradaram aos críticos, pois alguns cantores venderam bastante, como Hyldon, Cassiano e ainda Cláudio Zoli. Em relação a Tim Maia, é notório que, nos anos 1980, continuou a vender discos, mas progressivamente abandonando uma sonoridade mais "funkeada” para se aproximar da música romântica popular mais comercial.

E ainda a MPB, mesmo vendendo menos que as músicas consideradas de "baixa qualidade" pela crítica musical, ocupou definitivamente o status de uma música socialmente valorizada, sinônimo de "bom gosto", oferecendo à indústria fonográfica a possibilidade de consolidar um catálogo de artistas e obras de realização comercial mais duradoura e inserção no mercado de forma mais estável e planejada, em álbuns mais bem acabados, complexos e sofisticados. Esses artistas de MPB continuavam a ser sustentados pelos álbuns de custo mais barato e artistas populares e também pelas coletâneas, sobretudo as trilhas sonoras de novelas, que garantiam alta lucratividade para investimentos a longo prazo nos artistas da "faixa de prestígio". Dada a lógica de segmentação de mercado, a "faixa de prestígio" e a "faixa comercial" não se anulavam, sendo complementares, já que investir apenas em sucessos populares instantâneos não compensaria os riscos de não possuir um elenco estável de compositores-intérpretes, bem como um conjunto de obras de catálogo, de vendas mais duráveis ao longo do tempo. (NAPOLITANO, 2002b, p. 5)

Se, em um primeiro momento, a produção comercial nacional de apelo popular foi tomada pela black music brasileira, no começo dos anos 1980, aos poucos, o lugar desse gênero passou a ser ocupado por outras vertentes, como a música romântica - Roberto Carlos, Fábio Jr. - e o "sambão-joia” Agepê, Benito di Paula -, entre outros. Nomes consagrados como Jorge Ben Jor e Tim Maia deram continuidade a suas carreiras de forma estável, consolidando-se definitivamente dentro da MPB. Apesar de manterem ainda influências do soul e do funk em seus discos, passaram a incorporar também influências da disco music e da dance music em uma tentativa de tornar mais comerciais suas produções musicais. Guardando suas especificidades, os 
dois músicos conseguiram estabilizar-se no mercado fonográfico justamente por desenvolverem estratégias midiáticas nas quais foram capazes de incorporar elementos da black music norte-americana à dicção da canção brasileira, influenciados ainda pela bossa nova e pelo samba. Bebeto, seguidor da batida de Jorge Ben Jor, acabou por superar seu antecessor e manteve um ritmo regular de produção de discos, vendendo milhares de cópias até final dos anos 1980, mantendo-se ativo em shows nos bailes das periferias. Aos poucos, foi condicionando seu estilo mais para um tipo de samba de contornos românticos, que influenciou fortemente os novos grupos de pagode na virada para a década de 1990, como Negritude Jr., Só Pra Contrariar, Raça Negra e Art Popular.

Vianna (1988, p. 11) aponta ainda para a permanência da realização em menor escala de bailes animados por "um funk mais antigo", baseado na sonoridade de pré-sintetizadores e com uma batida mais lenta, gênero posteriormente chamado de funk melody. Em paralelo, eram realizados também bailes nos quais se tocava uma variedade mais lenta de R\&B, que ficou conhecido como charme e acabou se desenvolvendo como uma outra cena musical suburbana, bastante ativa na atualidade. Criado por DJs como Corello e Fernandinho, de uma geração posterior, os bailes charme eram voltados para o moderno R\&B americano, cujos set lists eram compostos por hits mais melódicos e de andamento mais lento, de grande apelo comercial. Essa sonoridade era ideal para o desenvolvimento de elaboradas coreografias coletivas, executadas pelos frequentadores que chamavam a atenção pela elegância no vestir - o traje "esporte fino" era uma exigência para muitas dessas festas -, o que inspirou o termo "charme" para designar o novo movimento. Os bailes charme rivalizavam com o funk, que retornou à mídia no final dos anos 1980, a partir da atuação de equipes que haviam se tornado verdadeiras corporações, como a Hollywood e a Furacão 2000, ainda em atividade. Dirigida pelo empresário Rômulo Costa, a equipe se desmembrou em gravadora, programa de TV e de rádio, organizando bailes que chegavam a reunir 30 mil "funkeiros" - inclusive muitos de classe média - no Rio e em outros estados. Esse novo tipo de funk tocado nas festas era originário do subgênero Miami bass. E os militantes das várias tendências do movimento negro brasileiro carioca 
deixaram os bailes de lado, “[...] não mais considerando-os como um espaço propício para a conscientização”. (VIANNA, 1987, p. 62)

Já um discurso musical mais politizado consolidou-se nas periferias paulistas através do advento do rap. Equipes de baile locais, como a Chic Show e a Zimbawe - que depois se tornou um selo e lançou o grupo de rap Racionais MCs -, rivalizavam entre si e continuavam organizando grandes bailes e shows. Ao longo dos anos 1980, a Chic Show continuou atuante e foi responsável pela vinda ao Brasil de grandes nomes da black music americana, como Gloria Gaynor, Earth, Wind \& Fire e Cheryl Lynn. A equipe lançou várias compilações em LP e produziu programas de rádio. Em seus megaeventos, enquanto os DJs se revezavam nos toca-discos, os primeiros videoclipes de rap eram exibidos nos telões, divulgando um novo estilo de dança, o break, e, posteriormente, o rap e cultura hip hop.

Em Salvador, o movimento Black Soul teve repercussões específicas, contribuindo para o que Risério (1981, p. 23) chamou de "blackitude baiana”. Entre 1974 e 1980, surgiu uma série de blocos afro, organizações de Carnaval criadas por jovens negros influenciados tanto pelos discursos do Black Power norte-americano, quanto pelo pan-africanismo e o movimento de libertação anticolonialista das ex-colônias africanas - em especial, da África lusófona. O primeiro foi o Ilê Ayê, seguido pelo Malê Debalê, Olodum e Muzenza, agremiações voltadas para a promoção da cultura afro-brasileira, inspirados tanto pelo samba e pelo candomblé, mas também que tinham um cunho de luta contra a discriminação racial, encontrando eco em sonoridades como, particularmente, o reggae, que influenciou a constituição do gênero musical do samba-reggae.

Em um momento de questionamento das convenções e de movimentações sociais globais, a cena black e seus desmembramentos foram particularmente incentivados por um contexto social jovem, que valorizava o corpo, o desafio às convenções e apresentava diferentes formas de mobilização por vias alternativas, que também se davam no âmbito da intimidade e da subjetividade. Os bailes e a música ofereciam um refúgio simbólico para um grupo que se sentia excluído do discurso nacional baseado em uma identidade mestiça e harmônica. Os blacks, nos bailes, dançando e ouvindo soul, enfatizavam uma crítica não só ao autoritarismo do governo militar, mas também 
às tradicionais formas de luta e contestação, o que era visto por muitos como uma forma de escapismo despolitizado e por uma traição às tradições.

A Black Rio apontou para a oposição a uma cultura institucionalizada, ao racismo e ao autoritarismo, por meio de uma contestação de uma cultura nacional unificada (DUNN, 2009, p. 202), resistindo à repressão e às críticas por meios singulares, negociando com as instâncias mainstream da indústria cultural e apresentando uma rasura ao centro da identidade nacional a partir de suas margens. No próximo capítulo, discutirei como a materialização de novas políticas de estilo a partir da cena da Black Rio representava a assunção de papéis mais complexos e variados por uma juventude negra brasileira, que compartilhava códigos culturais globais como reação e estratégia para lidar como as novas demandas socioculturais do cotidiano. Reinterpretado e subvertendo o valor e as regras em torno da música e dos objetos de consumo cultural, o estilo dos blacks era resultado de uma polifonia de citações diversas, e tentarei reconstituir essas complexas genealogias, baseadas em releituras e apropriações que resultaram em novas políticas culturais negras. 


\section{O estilo da Black Rio}

Os bailes soul promoviam uma atmosfera de valorização de um estilo que celebrava uma estética afro-brasileira inspirada no visual de artistas afro-norte-americanos. A configuração da cena da Black Rio se deu em torno da afirmação de diversos e tensivos processos de identificação heterogêneos, que, por meio da combinação de elementos distintos, gerou a constituição de um novo estilo que representava uma síntese, no nível significativo, de diferentes formas de adaptação e negociação, mas também de maneiras alternativas de afirmação racial. Essas eram estratégias que buscavam uma conscientização racial tomando por base uma valorização estética e uma celebração de um estilo, em detrimento de uma atuação político-pedagógica mais convencional.

Essas práticas, como aponta Yúdice (1997), formavam um conjunto de estratégias de reconversão cultural, adotadas mediante um sistema marcado pela globalização econômica e pela mundialização cultural. Para Yúdice, a reconversão cultural possibilita que os sujeitos passem a desenvolver novas práticas, habilidades e linguagens para sua reinserção em novas condições de produção, de consumo e de sociabilidade. Nesse sentido, as ações que caracterizaram o fenômeno da Black Rio não podem ser interpretadas apenas como atos de resistência racial. Uma visão mais produtiva sobre essa cena deve enfocar as nuances criativas e reconfigurações identitárias e estilísticas 
marcadas pelo consumo, embasando uma série de ações que apontava para um potencial provocador, subversivo e contraditório das políticas culturais, atravessando e recortando fronteiras de classe, raça e territórios.

Paulina Alberto (2009, p. 34) considera que a compreensão do sentido político da Black Rio passa pelo intenso poder transformador das políticas de estilo que a cena propagou, engendradas pela conjunção de práticas de consumo cultural e demandas por modernas formas de cidadania. Essas estratégias significativas seriam alternativas a ações institucionalizadas promovidas diretamente por movimentos sociais e políticos, como as práticas das organizações negras tradicionais. Dados seus limitados recursos e fontes, os frequentadores e produtores dos bailes black produziam respostas mediadas que combinavam criatividade e consumo para configurar seu estilo, encenando e performatizando uma linguagem singular que marcava suas experiências com um explícito gesto político e significativo.

Os estilos construídos dentro e a partir dos bailes - o estilo dos blacks - eram superfícies da manifestação de tensões entre polaridades como subalternos $\mathrm{x}$ dominantes, negros $\mathrm{x}$ brancos, periferia $\mathrm{x}$ centro, tradicional $\mathrm{x}$ moderno, resistência x cooptação. Mas, ao mesmo tempo, representavam acomodações dessas dicotomias de forma ambígua e ambivalente. Essas posições se alternavam em jogos reflexivos e complexos que representavam os embates, as fragmentações e as contradições presentes na constituição da própria sociedade brasileira. Os estilos, enquanto práticas significantes e codificadas compostas por elementos como música, iconografia visual, performances, roupas, estéticas e sistema de valores (HEBDIGE, 1979), se tornavam indícios de um significado e de uma identidade em disputa, simbolizando, simultaneamente, uma recusa a visões homogeneizantes e também um desafio oblíquo a uma hegemonia e a uma cultura mainstream, apresentando novas práticas culturais periféricas e cosmopolitas.

Esse contexto, para Preciado, condiz com o deslocamento do lócus da construção da subjetividade política das tradicionais categorias de classe para instâncias transversais como o corpo, a sexualidade, a nacionalidade, a raça e o estilo (inclusive a imagem), criando novos patamares para a condição de subalternidade. (CARILLO, 2010, p. XX) Angela Prysthon (2004) propõe outra interpretação para o fenômeno, abordando a noção de cosmopolitismo 
periférico, em que ser cosmopolita na periferia significa reconhecer a diferença cultural e as marcas locais específicas, inserindo-as no conjunto mais amplo da metrópole contemporânea. Essa situação é particularmente incentivada por reformulações, remapeamentos e relativizações culturais que buscam fissuras tanto da realidade social quanto nas tradições locais, recriando os traços de uma cultura que se pretende urbana, internacional, moderna e, ao mesmo tempo, alternativa e ambígua. O sujeito cosmopolita periférico estabelece, pois, novos centros e demarca outros territórios (PRYSTHON, 2004, p. 38), sem negar a referência e a reverência ao(s) centro(s) em um processo de "autodescoberta que pode levar ao estabelecimento das primeiras políticas da diferença”.

Essas políticas da diferença - ambivalentes, problemáticas, contraditórias - são incompletas e estão em permanente mutação. No contexto da Black Rio, elas trabalham sua retórica no plano estético-celebratório que combina dança, moda, música, lazer, performance, estabelecendo um diálogo maleável e instável entre processos alternativos de subjetivação e as condições de existência material. Essas condições criam uma comunidade simbólica, pautada pelo consumo de gêneros musicais, símbolos e objetos significativos, que nunca formam um conjunto uniforme. Assim, se a cena black desde sempre foi recortada por diferenças étnico-raciais e de classe que não coincidiam integralmente nem formavam um todo homogêneo, ela dividia entre os seus integrantes um mesmo tipo de linguagem e de práticas significativas, manifestas no estilo, uma resposta mediada e codificada (HEBDIGE, 1979, p. 80) por transformações que estavam afetando toda a comunidade.

Os estilos facilitam a transmissão de informações e mensagens, elaborando dramatizações de linguagens em imagens complexas que favorecem a expressão de novas realidades. Na construção de um estilo black, muitas vezes, estereótipos foram acionados como estratégias de representação e formas de identificação que revelavam tensões entre práticas constituídas e os novos anseios sociais. Novos estilos passaram a ser elaborados a partir de imagens estereotipadas, removendo sua fixidez e representando alteridades dinâmicas, que deram autonomia aos sujeitos para a produção de imagens distintas que lhes permitiram postular equivalências, semelhanças e identificações diferentes do que estava posto. O compositor baiano Djalma declarou 
a Risério (1981, p. 26): "Nós, os negros, já saímos da coisa do maculelê, samba de roda e capoeira. Nossa criação, nossa cultura, andaram [sic], apesar da repressão. Uma postura racista é querer nos imobilizar no que dizem ser as formas puras de nossa cultura”. Em contraste com narrativas da marginalidade, pobreza, segregação e tradição, os bailes começaram a difundir uma mensagem de valorização da beleza negra, na mesma medida em que passaram a oferecer a seus frequentadores outras possibilidades de identificação que não passassem necessariamente por traços de uma brasilidade, como reafirmou Mr. Funky Santos a Essinger (2005, p. 47): “Antes da black music, o que havia para o povão era futebol, samba e jovem guarda. Só som burro, refrão cheio de laia-laiá. Foi com a soul music que o negro passou a se valorizar, cuidar do visual”.

\section{Classe média negra}

Na configuração do estilo na cena da Black Rio, havia um projeto estético baseado em uma construção social que conjugava individualidade e coletividade, afirmando modos de vida e propondo novas representações de acordo com demandas inéditas em consonância com movimentos internacionais. Nesse processo, havia a rejeição de uma identidade cultural nacional para a construção de comunidades que se articulavam tanto em relação aos bailes, quanto em relação aos atos de consumo cultural de bens simbólicos. O que ocorria pela interconexão com outros grupos localizados na África e, mais flagrantemente, nos EUA. A partir desses fluxos e diálogos, as sensibilidades passaram a se modificar, estabelecendo novas formas de convivência local e propondo diferentes formas estéticas e experiências pessoais diversas. É a esse processo a que Sansone (2004) se refere ao falar em "globalização negra”, que diz respeito à disseminação de musicalidades, símbolos, estilos de vida e uma estética vinculada às populações negras do eixo Nova York, Los Angeles e Londres, por exemplo, e que colaborava para a internacionalização de ícones negros, como personagens de filmes (Shaft, Cleópatra Jones), artistas (James Brown, Michael Jackson), intelectuais e militantes (como Malcolm X e Angela Davis). 
Nesses trânsitos simbólicos, a cultura negra urbana norte-americana é apropriada como sinônimo de modernidade, se estabelecendo como referencial compartilhado de um cosmopolitismo, como algo positivo, especialmente em relação aos produtos da cultura brasileira, compreendidos como um patrimônio que havia sido apropriado indevidamente pelas elites, e pelo Estado, e também como um signo anacrônico de uma tradição distanciada da contemporaneidade. Como exemplo, podemos lembrar o comentário de Hamilton Bernardes Cardoso, jornalista e ativista negro, em 1977 na reportagem televisiva "Da Senzala ao Soul” (1977): "Quando a classe média, o branco, começou a entrar nas escolas de samba, a gente começou a se sentir um pouco como se estivesse sendo expulso de lá". Assim, ao voltar-se para os EUA, a juventude black buscava reformular e atualizar seus repertórios culturais, mesmo que de maneira problemática, se aproximando de fluxos, sonoridades, estéticas e visões mundializadas que poderiam ser acessadas por meio do consumo da cultura de massa americana - ainda que essa cultura afro-americana fosse, no contexto dos EUA, uma produção periférica.

Contudo, ainda que a posição privilegiada dos Estados Unidos permita uma maior divulgação de suas ideologias, entende-se aqui que a cultura negra naquele país ainda se mostra como uma cultura discriminada e a divulgação das manifestações negras da época não pode ser vista apenas como uma estratégia de dominação, mas refletem a força das manifestações políticas, sociais e culturais existentes. (SILVA, 2013, p. 142)

Isso inclui o fato de que a preferência por ouvir e consumir canções em inglês permitia que os frequentadores dos bailes demarcassem "estratégias conceituais, simbólicas, sociais e linguísticas de valorização das práticas musicais, hierarquizando inclusive gostos e ideias". (TROTTA, 2013, p. 10) Essa anglofonia não pode ser interpretada apenas como reflexo do imperialismo norte-americano, já que a linguagem é um instrumento de poder, de hierarquização e de legitimação simbólicas. Mas a performatização do gosto pelo inglês dava o tom também de um desejo por se inserir em um contexto global e em uma produção cultural cosmopolita, experimentando uma sensibilidade 
e uma partilha mundial de valores que acabavam por estabelecer formas de vínculo e pertencimento.

O desejo pelo novo, pela vivência do cosmopolitismo e a vontade de se distanciar de uma identidade brasileira que estaria baseada no apagamento de traços negros mais evidentes em prol de uma valorização do fator mestiço era uma estratégia também de desvio e subversão das estruturas racistas da sociedade. Os frequentadores dos bailes soul, ao consumir essa cultura de massa afro-americana, poderiam se colocar em uma posição conveniente, distintiva e mais positiva. E isso representava também a partilha de sentimentos e demandas comuns a ambos os grupos em situação desprivilegiada, que lutavam por autonomia e igualdade, em uma espécie de ativismo transnacional ou um "transnacionalismo negro", segundo conceitua Hanchard (2001).

Isso poderia apresentar um possível instrumental para a produção de representações e de atos afirmativos que trouxessem a esses jovens negros mais benefícios do que a identidade mestiça nacional. Vantagens como uma possibilidade de igualdade, de combate à discriminação, de valorização estética e de ascensão socioeconômica, cujas perspectivas eram transmitidas pelas imagens de sucesso presentes nas páginas da revista Ebony, nos filmes e nas imagens de cantores negros famosos, cujas canções serviam como trilha sonora para essa possibilidade de transformação.

Esse impulso distintivo demarcado pelo desejo de consumo de uma cultura cosmopolita - americana, internacional, moderna, jovem - também tinha relação com a demonstração de uma emergente ascensão social e econômica por parte dos frequentadores da cena black. Os bailes representavam uma opção de lazer para populações marginalizadas e periféricas, mas foi entre a juventude negra suburbana com um maior poder de compra que o estilo black foi incorporado e difundido com mais veemência. A reportagem da revista Veja sobre a Black Rio de 1978 já apontava a especificidade do público da cena. Ele não era composto por cidadãos integrantes do lumpen, em referência ao lumpemproletariado, que, de acordo com um vocabulário marxista, dizia respeito a uma classe subproletariada, um grupo populacional situado socialmente abaixo da classe trabalhadora, em termos de condições de vida e de recursos econômicos. 
[...] os adeptos do Black Rio formam uma gama que abrange desde o proletário até o cidadão de classe média, todos integrados à economia urbana e decididos a abandonar o acanhamento marginal das gafieiras e o irritante enquadramento das escolas de samba-empresas. Mas a capacidade aquisitiva do Black Rio pode ser avaliada por aqueles poucos vinte carros parados à porta de bailes onde se balançam milhares de pessoas. (BLACK RIO, 1978, p. 154)

Embora uma grande maioria de negros ainda permanecesse no subproletariado urbano naquele tempo, após 1930, notava-se a emergência de uma pequena quantidade de não brancos localizados em uma classe média formada por profissionais liberais, funcionários públicos e militares. Houve também uma maior incorporação de um número substancial de negros e mulatos à classe trabalhadora industrial no período. Esse setor da população experimentou uma maior soma de ganhos econômicos e sociais em relação às gerações passadas e pôde ter acesso a mais educação, saúde e opções de lazer.

O crescimento de uma classe média negra acompanhou o considerável desenvolvimento dos segmentos médios da população brasileira como uma consequência direta do milagre econômico empreendido pelo governo militar entre 1968 e 1973. Durante o regime Médici (1969-1974), o poder ideológico e de repressão por parte dos militares atingiu o auge, especialmente a partir de 1968, com a promulgação do AI-5. Mas a economia ia bem, com crescimento médio de $11 \%$, ajudado pela grande expansão industrial, agrícola e de exportação de minérios - especialmente facilitada pela supressão de demandas por direitos trabalhistas. O “milagre”, no entanto, não reduziu drasticamente a desigualdade socioeconômica, privilegiando o crescimento em detrimento do bem-estar coletivo. (DUNN, 2009, p. 190) Mas pesquisas mostram que, a partir de 1973, muitos brasileiros ascenderam socialmente e ingressaram nas classes médias, primeiro nas grandes cidades e depois nas cidades menores e no campo. (SANTOS, 2001, p. 135) No crescimento dos setores médios, o componente negro nessa categoria observou um aumento menor, mas significativo. A educação básica também foi privilegiada e, no começo dos anos 1960, a matrícula no ensino primário cresceu $60 \%$, contando também com o aumento da oferta de vagas e escolas (MOTTA, 2000, p. 88) 
e com um acréscimo do ingresso no nível universitário, em faculdades particulares por parte de indivíduos negros.

Para Fernandes (1978), a tendência à proletarização foi um dado importante no período, relacionado ao desenvolvimento industrial nacional de bens de consumo, incluindo ainda um crescimento do setor de serviços. Mesmo assim, as chances de ascensão social para "pretos" e "pardos" continuavam muito menores do que para os brancos, como comprova Hasenbalg (1979), da mesma forma que esses dois grupos continuavam apresentando os menores graus de instrução e os menores índices de participação na distribuição de renda.

Entende-se aqui "classe média" em critérios objetivos como escolaridade, tipo de ocupação e nível de renda. Mas, em relação a afro-brasileiros, é um grupo ainda subalternizado e que encontra dificuldades para se manter nessa classe. A classe média negra possui uma especificidade descrita por Figueiredo (2004, p. 203) em sua composição, pois é formada em sua maioria por indivíduos filhos de trabalhadores manuais, que não herdaram bens imóveis e que sobrevivem exclusivamente dos salários, estando fora de uma socialização típica de um ambiente de classe média e, portanto, com aspirações e experiências de classe diferenciadas. Mesmo os poucos que conseguiam ingressar no nível superior tinham dificuldades de ingresso em um mercado de trabalho em vias de expansão, ora sendo preteridos, ora mal remunerados, especialmente em relação a jovens profissionais brancos. O peso da cor e as separações impostas pelo racismo deixavam explícito que as oportunidades não seriam as mesmas para jovens negros e brancos, especialmente naquele tempo, o que reduzia as possibilidades de mobilização social, mas não impedia um aumento progressivo do poder de compra e do maior acesso a diferentes bens culturais. O consumo e outros traços distintivos eram formas dessa classe média negra se distinguir perante o conjunto da população afro-brasileira, como pontua Praxedes (2003, p. 2):

Neste sentido é que os afrodescendentes se empenham para a aquisição de certos símbolos que garantam sua distinção em relação ao restante dos afrodescendentes pertencentes às camadas populares, como a posse de um diploma universitário, o exercício de um 
trabalho não manual e o cultivo de algumas práticas de consumo que envolve diferenças no tamanho das residências, no modelo e ano do automóvel adquirido, no número de empregados domésticos e no modo de vestir.

Nos anos 1970, os indivíduos pertencentes a essa classe média negra parecem ter sido colocados em uma posição ambivalente e conflituosa. Havia um movimento no sentido da incorporação de padrões da "sociedade dominante" (SILVA, 1980, p. 6), buscando um reconhecimento em meio a seus pares por conta da ascensão econômica, e um desejo da afirmação de um lugar legítimo na sociedade - como estava presente nas aspirações dos criadores do Clube Renascença. Mas, ao mesmo tempo, o acesso a mais informação gerava novas aspirações e inquietudes, deflagrando uma maior demanda por direitos e igualdade. Assim, muitos indivíduos negros dos setores médios começaram a demonstrar maior interesse por questões ligadas ao orgulho negro, em novas manifestações de consciência racial e social, o que levou a investimentos mais efetivos na constituição de organizações negras de diversas ordens. Um orgulho negro que, de acordo com Giacomini (2006, p. 196), “[...] supõe, propõe e promove uma coesão, uma espécie de solda entre os indivíduos que se reconhecem como iguais, operando como uma base fomentadora de vínculos, ligações, cimentando e conformando o grupo étnico consciente de si mesmo".

Mesmo se propondo a uma união, essa classe média negra representava um processo de estratificação e diferenciação interna com uma consequente modificação no padrão de relações sociais dentro do conjunto populacional afro-brasileiro, criando obstáculos à produção de uma identidade coletiva e a uma mobilização mais ampla. (HASENBALG, 1979, p. 249) Essas diferenciações existiam tanto dentro do próprio segmento negro médio quanto em relação aos negros mais pobres. Mas o acesso a um maior nível educacional e o enfrentamento de formas de discriminação no processo de ascensão social levaram alguns membros dessa "elite" negra a se posicionarem como possíveis lideranças de um movimento de luta contra o racismo. Figueiredo (2002) nota ainda que essa maior escolarização e ascensão socioeconômica não implicaram um possível "embranquecimento", em que os estratos médios 
supostamente pudessem correr o risco de abandonar suas tradições e afiliações étnicas, como indicavam alguns estudos clássicos das relações raciais brasileiras. Esses negros, ao se depararem com situações discriminatórias em locais de trabalho, restaurantes, bairros residenciais de classe média, escolas particulares, acabaram por desenvolver uma "identidade étnica tardia". A ascensão social de negros e mulatos acabou por possibilitar uma maior reflexão e valorização racial, fortalecimento da identidade étnica e o cultivo de um "orgulho da cor e da ascendência negra”. (FIGUEIREDO, 2002, p. 116)

É importante também mencionar que esses grupos médios negros passaram a se fixar nas regiões suburbanas da cidade, ao longo da malha ferroviária, como visto no capítulo "Bailes e clubes de subúrbio", e fizeram com que o subúrbio passasse a ser, no lugar de um território marcado por imagens ligadas à pobreza, ao mau gosto e ao provincianismo, um nascedouro de novas linguagens, estéticas, modas e estratégias de sobrevivência, criando valores mais positivos e sentidos mais complexos para a vida social e para a formação desse "ethos suburbano", que implicava uma vida social com traços mais comunitários e vínculos sociais mais intensos. Paralelamente, o subúrbio carioca estabelecia-se como um espaço urbano integrado, mas subordinado tanto à cidade quando ao mercado, cujos habitantes ocupavam os espaços públicos de maneiras alternativas, a fim de obter os meios de garantia de uma cidadania cultural e de uma expressão política, mesmo que acessando os benefícios da modernização e do desenvolvimento econômico de forma diferenciada ou parcial. Essa condição teve estreita relação com o desenvolvimento de novos aparatos de lazer e produção cultural por classes sociais intermediárias em vias de crescimento, que passaram a produzir outras visões sobre suas culturas, experiências e identidades. Mesmo que essa modernização híbrida tivesse um caráter excludente e desigual, ela gerava efeitos estruturantes positivos sobre práticas sociais nos subúrbios e espaços periféricos.

Na medida em que, entretanto, a urbanização precedeu historicamente a industrialização, criou-se nos países da América Latina um 'efeito demonstração' que consiste em assumir como valor, por efeito da vida urbana e do consumo das idéias e de modas do Ocidente, 'pautas sociais' dos países centrais, sem que tivéssemos vivenciado as mudanças estruturais, ou seja, na base econômica, que 
sustentaram essas mesmas idéias nos países do capitalismo central. [...] Ora, o efeito demonstração supõe que a modernização da economia se efetua através do consumo. (PINHO, 2006, p. 180)

A modernidade, como valor e ideologia, era concretizada no consumo de mercadorias e também de bens simbólicos, notadamente lazer, música e outros produtos massivos. A cena black, pois, foi consequência desse momento em que jovens trabalhadores e estudantes negros passaram a experienciar suas vivências de classe e cor de forma diferente das gerações anteriores, mediante o acesso a um conjunto maior de informações que gerou a manifestação de outras demandas e novas formas de luta contra o racismo. Esses novos repertórios significativos faziam com que sentissem a necessidade de expressar suas individualidades em meio a uma coletividade constituída a partir dos bailes. O consumo para esses indivíduos assumia um papel de prática ativa de produção de significados sustentados socialmente, que funcionavam como uma espécie de compensação para o sentimento de exclusão e para a segregação racial. (PINHO, 2006) Essa situação também gerou uma outra ambivalência, pois o desejo de desfrutar dos bens simbólicos e materiais relativos a um ideal de modernidade criava uma tensão e incompatibilidade com uma "construção sócio-antropológica da categoria negro", em referência à expressão de Figueiredo (2004), que se baseava em uma visão essencialista do negro simbolicamente determinada enquanto ser "folclórico", que deveria se voltar apenas para suas matrizes culturais tradicionais e, portanto, fora da contemporaneidade.

Essas novas formas de exercício da negritude geravam críticas que se acirravam especialmente nas tensões entre o soul e o samba. Os adeptos do soul, bem como a cena black, acionavam a valorização de aspectos ligados a um estilo de vida jovem, em detrimento de formas culturais ligadas a um mundo "adulto", como o samba. Essa ideia de juventude se refere a uma construção sociocultural, investida de símbolos e valores específicos, dados a partir da relação entre condições biológicas, papéis sociais e construções simbólicas. Suas definições, variáveis de acordo com o contexto, também têm relação com o advento das sociedades industriais modernas ocidentais e com o surgimento de novos segmentos de mercado ligados ao consumo massivo 
e ao capitalismo do pós-guerra. Assim, a juventude era reificada e positivada no espaço dos bailes, o que contrastava com o samba, que representava a tradição, as "raízes" e a "velha guarda". (CAVALCANTI, 1981, p. 15) A ideia de juventude propagada pela cena da Black Rio tinha algumas conotações implícitas para além da faixa etária. Ser jovem significava, no contexto dos bailes, ser alegre, interessante, black (e não negro ou preto), moderno, anglófono, que desenvolvia novas formas de uso do corpo e performatizava um estilo diferencial, com um acesso especial a uma cultura internacional, como relembra um entrevistado em Cavalcanti (1981, p. 6-7): "Desde a primeira vez que fui ao 'Black Rio' senti que era uma coisa 'quente', 'ligada'... Transa pra gente 'black' jovem sem coroas nem turista pra perturbar”.

No Brasil, o Instituto Brasileiro de Geografia e Estatística (IBGE) classifica demograficamente como jovens aqueles indivíduos que possuem entre 15 e 24 anos. Mas a ideia de juventude ultrapassa limites de idade e pode ser considerada uma categoria trans-etária, conceptualização proposta por Vianna (1992), cujos valores e significados são difundidos, internalizados e reproduzidos por diferentes indivíduos e grupos sociais enquanto símbolos estéticos e comportamentais, manipulados no domínio do consumo. Assim, um ideal de juventude está associado às dinâmicas do mercado, às transformações sociais, a uma maior vitalidade e a formas diferenciadas de usos do corpo, o que implica uma articulação com padrões de beleza, danças, modas, linguagens e comportamentos atualizados. Essas circunstâncias implicam uma identidade aparentemente "universal”, cujos parâmetros são difundidos mundialmente, especialmente em um contexto de globalização da cultura de massa, cujos produtos são divulgados pelo cinema, pela televisão, pela indústria da música e da moda.

Mais uma vez, a cena black articulava a oposição de referenciais jovem versus adulto, moderno versus tradicional, representando novas aspirações de uma juventude subalterna por um sucesso que as gerações parentais supostamente não haviam conquistado, em termos econômicos e de autoestima, independência, satisfação pessoal e, mais ainda, autonomia para a ocupação de espaços sociais significativos. Isso poderia simbolizar uma maior mobilidade social, que implicava um maior trânsito entre grupos distintos e mais possibilidades de convivência. Ao mesmo tempo em que os bailes eram espaços 
fundamentais para a sociabilidade de uma juventude negra, eram também territórios de encontros entre brancos, negros e mestiços, ou uma juventude afro-mestiça, como prefere Risério, que ousavam ultrapassar, no momento efêmero da festa, fronteiras de raça, cor e classe. Na efervescência do baile, de encontros, embates e fluxos, a cultura juvenil era concretizada na experiência musical coletiva, em que a vivência em grupo estabelecia modelos e parâmetros para a configuração de um estilo particular que apontava para novas formas de ser jovem, negro, suburbano, cosmopolita, moderno e político.

$\mathrm{Na}$ construção dessa versão pessoal de uma cultura juvenil negra e moderna, era possível encontrar uma complexa variedade de opções na conformação dos estilos de vida, especialmente quando se pensa nas escolhas estruturadas das gerações anteriores. Esse conjunto de novas movimentações e novas visões de mundo favoreceu o reconhecimento de que símbolos pré-construídos estavam saturados. E a juventude black ultrapassou os limites da tolerância às ideologias, o que permitiu a ampliação do campo da consciência (SANTOS, 2001, p. 135) na mesma medida em que apresentou novas formas de exercício da negritude. Assim, participar da cena da Black Rio revelava-se como uma forma de ingressar na modernidade ocidental ou, pelo menos, de se imaginar localizado nesse contexto, lugar possível para a autoidentificação com a negritude global e uma contemporaneidade, mesmo sendo jovem, negro, subalterno e brasileiro.

\section{Novos estilos, novas negritudes}

Negritude, na acepção original da palavra, se referia a um movimento literário dos anos 1930 baseado em uma ideologia pan-africanista e que pregava a solidariedade a partir da origem comum entre os povos negros oriundos da África. Fundada por Léopold Senghor, poeta, intelectual e político negro, eleito presidente do Senegal (1960-1980), a négritude era baseada na valorização de todas as manifestações culturais de matriz africana, postulando uma lógica própria para a fundação de uma razão negro-africana. Da mesma forma que o pan-africanismo, a négritude partia da premissa de uma unidade e uma história comum para todos os povos africanos, em um quadro fixo de referenciais. Mais do que um movimento literário, era um ato político que 
clamava por reconhecimento ao enfatizar o combate ao racismo e a reflexão sobre a condição do negro e de sua relação com o colonizador.

A ideia de negritude, aos poucos, passou a ser utilizada como uma referência a uma espécie de consciência étnica e política, voltada para uma mobilização a partir de uma autodefinição baseada em uma herança cultural africana mítica - história, arte, religião, valores etc. - que passa pela cor, como uma manifestação física e fenotípica da identidade. Nos anos 1960, a luta do Movimento pelos Direitos Civis, liderado por Martin Luther King, e a atuação de Malcolm X, porta-voz da organização Nação do Islã, bem como os escritos do intelectual negro Frantz Fanon, pavimentaram a estrada para o surgimento de novos movimentos políticos negros, como os Panteras Negras, nos EUA. Os membros do Black Panther Party, em resposta à violência racial, aderiram a táticas de guerrilha urbana e formularam uma redefinição política, social cultural e estética para as populações afro-americanas, baseada no Poder Negro (Black Power), que desmistificava o conceito de classes sociais da esquerda comunista. Já na África do Sul, diante do acirramento das ações do apartheid, a Organização de Estudantes da África do Sul (Saso) criou o conceito de consciência negra, baseado em uma política libertária que teve como principal representante Steve Biko. Para Gomes (2006, p. 219), o ideário da consciência negra afirmava a positividade do corpo negro em seus traços físicos, marcas identitárias que deveriam ser entendidas como "sinais diacríticos” ressignificados com base em uma leitura política, compreendendo os mecanismos dos condicionamentos psicológicos do racismo que impediam uma tomada de posição do negro diante da discriminação.

Desse modo, a negritude como categoria foi incorporada enquanto recurso de linguagem que exprime uma dada realidade social, localizada em um determinado momento histórico, e que correspondia, no nível simbólico, a uma identidade racializada negra, cujas inferências contextuais eram acopladas à categoria étnica de uma africanidade. E, se a negritude e seus símbolos historicamente nascem da opressão racial escravista, não é possivel compreender essas dinâmicas subjetivas apartadas desses regimes de exclusão e desigualdade.

Assim, é fundamental salientar que a negritude ou a identidade negra - expressões utilizadas como sinônimos -, enquanto discursos, são contextuais, 
mas políticos, pois possibilitam o posicionamento daqueles que se compreendem como negros diante da sociedade, marcada por uma longa história de segregação baseada na ideologia racial. De maneira geral, os processos individuais de identificação ocorrem na afirmação das diferenças perante o outro, de tal forma que a individualização nunca está integralmente dissociada do reconhecimento dos outros. Isso faz com que as subjetividades individuais tanto organizem as produções simbólicas do indivíduo quanto gerem significados coletivos. Isso nos permite compreender a identidade negra como recurso político e, portanto, essencialista, pois revela aspectos selecionados de uma determinada história, de uma estética e de uma vivência de recriação cultural. Nesse processo essencializante, marcadores que mudam no tempo e no espaço - como a cultura, a corporeidade, a musicalidade, a religiosidade e um amplo conjunto de símbolos e valores - assumem uma centralidade estratégica e podem ser acionados de acordo com distintas circunstâncias e conveniências.

O fator histórico, que também é inerente à própria noção de raça, é determinante fundamental da identidade negra, que molda o coletivo a partir da união de elementos e de um sentimento de continuidade social e cultural, ancorando afetos, narrativas, valores e experiências. "Assim, temos, na subjetividade dos afrodescendentes o resultado também de um projeto histórico implícito nas trajetórias civilizatórias trans-nacionais e nacionais”. (GONÇALVES, 2010, p. 372) O lugar idealizado da origem e da sua autenticidade para essa negritude seria a África, como modalidade ideológica e mítica, onde residiriam referências de ancestralidade que demarcariam traços e heranças culturais articulados à conformação da identidade. A ancestralidade se refere tanto a aspectos tradicionais de algumas nações africanas, que possuem a marca da oralidade, quanto a uma maneira existencial e afetiva de se relacionar ritualisticamente com a divindade e com antepassados mortos.

De forma que o próprio corpo indumentado no estilo Black passa a ser o suporte da construção da etnicidade daquele grupo, revelando diferenças e construindo fronteiras. A 'moda' soul se afasta do costume dominante que impõe um modelo de beleza ou imagem (cabelo alisado, roupas no estilo surfwear da zona sul), e dialoga com a 
'tradição', no caso a 'invenção' da negritude moderna pan-africana dos povos da diáspora. (BRAGA, 2015, p. 89)

A "África” a que se reportam esses movimentos de negritude, explica Hall (2003, p. 31), é uma "construção moderna, que se refere a uma variedade de povos, tribos, culturas e línguas, e cujo principal ponto de origem comum situa-se no tráfico de escravos”. E que no contexto das Américas e das ex-colônias foi retrabalhada e ressignificada na atualidade da diáspora, cuja ideia se apoia em uma concepção binária de diferença, fundada sobre a fronteira de exclusão e dependente da construção de um "Outro". (HALL, 2003, p. 33) Essa “África” garante recursos simbólicos de sobrevivência, oferecendo formas e padrões culturais que circulam e se intercambiam com outros valores e costumes, abrindo novas possibilidades de reorganização da vida em sociedade. (TAVARES, 2010, p. 82) Na estética africana apropriada nesses movimentos diaspóricos, é importante destacar que havia uma determinada preferência por elementos presentes em algumas culturas do continente consideradas integrantes de uma "África negra” ou África subsaariana - de países como África do Sul, Benin, Quênia, Nigéria, Senegal, por exemplo -, região localizada ao sul do Deserto do Saara. Mas não se enfatizavam tanto traços relacionados às áreas do Norte da África ou África setentrional, onde estão situados países mais ligados a um imaginário do Oriente, de cultura majoritariamente árabe, como Egito, Marrocos, Tunísia, Argélia. Isso pode ser explicado pelo fato de que foi a partir da África subsaariana que se estabeleceu o fluxo do comércio de escravos no período colonial.

Martín-Barbero (2008, p. 245), ao abordar a constituição do popular-urbano pela incorporação das produções culturais negras à cultura das cidades e à indústria cultural, discorre sobre o momento em que o "gesto negro se torna popular-massivo”. Nessa passagem, ainda que conflituosa e ambígua, seria possível, de acordo com Hall (2003), perceber em seus repertórios culturais populares as diferentes experiências sensíveis das comunidades negras.

Em sua expressividade, sua musicalidade, sua oralidade e na sua rica, profunda e variada atenção à fala; em suas inflexões vernaculares e locais; em sua rica produção de contranarrativas; e, sobretudo, em 
seu uso metafórico do vocabulário musical, a cultura popular negra tem permitido trazer à tona, até nas modalidades mistas e contraditórias da cultura popular mainstream, elementos de um discurso que é diferente - outras formas de vida, outras tradições de representação. (HALL, 2003, p. 342, grifo do autor)

Na geografia da diáspora negro-africana, as formas de vida, experiências e representações materializam-se na importância dada aos estilos como formas de expressão, de linguagem e superfícies de comunicação. O estilo baseado na estilização retórica do corpo possibilitava a ocupação de novos espaços sociais e a apropriação de patrimônios culturais alheios, indicando o pertencimento a uma comunidade. Esse estilo black globalizado é marcado por processos desterritorializantes, estabelecido e estabelecendo novas relações sociais, novas formas de associação, pertencimento e lealdade, a partir de trocas e fluxos complexos, criando parâmetros diferenciados de interação entre indivíduos e espaços. Para Hall (2003, p. 342), o estilo, desse modo, ocuparia lugar central dentro do repertório negro, em que o corpo seria o único capital cultural de que dispunham os povos da diáspora. "Temos trabalhado em nós mesmos como telas de representação”.

Hoje em dia o crioulo já está numa de afro. Antigamente o crioulo esticava o cabelo. Hoje em dia o crioulo vê que não é nada disso. Hoje em dia os crioulos já procuram fazer o máximo que os crioulos americanos os nossos irmãos lá do outro lado, está entendendo. Então dá nisso que você está vendo, cada um lança a sua moda, cada um dança a sua maneira, é isso aí. (MR. FUNKY SANTOS, 1976, p. 4)

O estilo, pois, possibilita a inscrição do corpo negro na paisagem urbana por meio de estratégias codificadas de consumo cultural e jogos ambivalentes entre valores essencializantes, estereótipos e representações alternativas que, combinados às dinâmicas globalizantes, tensionam os limites dos processos de individuação. A esse respeito, Pinho (2005, p. 141) argumenta que "as formas de alteração visual, de manipulação da aparência e de reversão de estigma são formas políticas de inscrição da visualidade afrodescendente no 'corpo' da cidade, subvertendo a paisagem e reinventando os lugares [...]”. 
O estilo, assim, emerge da articulação entre atos de consumo, espaço, corpo e discurso, dando nova inflexão às formas convencionais de intervenção crítica negra, apresentando um gesto performático ao mesmo tempo afirmativo, subversivo, mutável e permanentemente em disputa.

Na conformação do estilo de vida, Giddens (2002, p. 79) entende que ele engloba "um conjunto mais ou menos integrado de práticas que um indivíduo abraça, não só porque essas práticas preenchem necessidades utilitárias, mas porque dão forma material a uma narrativa particular de autoidentidade”. A partir do estilo, foi possível ao grupo dos frequentadores dos bailes soul reavaliar suas experiências estéticas na vida cotidiana e ainda reconfigurar suas subjetividades acomodando realidades e significados. Ao incorporar as aspirações daquela coletividade, que reelaborava outras formas negras de identificação, esses indivíduos criavam um estilo baseado na dramatização e performatização pública de uma identidade por meio dos gestos, da fala, das roupas e do corpo. Um corpo que pode ser definido, segundo Pinho (2005, p. 138), "como uma instância da reprodução da sociedade, que opera através do processo de transmissão de estruturas culturais para o suporte da subjetivação". Nessas performances de negritude, é possível observar a centralidade da cultura na linguagem do estilo, catalisado pela música soul, capaz de expressar interesses, visões, valores e capacidades organizativas das diferentes gerações e grupos étnicos no tempo e no espaço. (MARTINS, 2010, p. 121)

A identidade e suas marcas são definidas a partir das diferenças entre $o$ eu e os outros (FOUCAULT, 2002), aquilo que se é, que os outros não são e que existe no limite da sua diferença. Homi Bhabha (1998, p. 55), em O local da cultura, sugere ainda que a identidade ocupa um lugar de fronteira, um espaço intermediário (o terceiro espaço) de alterações políticas. E as identidades, para serem incorporadas e estabelecidas, precisam ser elaboradas no pertencimento ou na confrontação com um determinado grupo identitário, cuja coletividade aponta para fragmentações que tornam os processos identitários contemporâneos situacionais e transitórios, mesmo que ainda possuam pontos de fixidez como o fenótipo, no caso da identidade negra, que podem ser variáveis de acordo com o contexto social, a geração, ou o sistema classificatório local. Essas variações tornam as identidades dependentes da linguagem, que permitem a reencenação de práticas sociais e a mutação de 
significados, cujos discursos são permanentemente negociados, repetidos, traduzidos, verificados, reelaborados, individualmente e em grupo: "fragmentos de eu, contados por mim e experimentados por muitos". (MORTARI, 2004, p. 26)

Nesse processo de elaboração discursiva das identidades, a performance consiste na repetição de normas que regulam o fazer cultural na coletividade, eventualmente alterando-as criativamente e até questionando-as, em um processo de bricolagem que inclui novos elementos, muitas vezes aparentemente díspares. Ao acionar a identidade, a performance se vincula e se circunscreve no corpo, tanto o coletivo quanto o individual, representando fisicamente um acontecimento social, materializando no corpo os valores da cena musical, em rituais sensíveis e afetivos de elaboração, narração e repetição de discursos e subjetividades que são acionados pelos sujeitos.

$\mathrm{Na}$ correlação entre estilo e identidade, a performance é o elo que se estabelece no corpo como espaço possível para reconfigurações subjetivas e para a construção política, enquanto conjunto de convenções configuradas a partir do processo de escuta e fruição musical que mobilizam uma série de funções comunicativas e sociais. Para o senso comum, a palavra "performance" é associada à arte, recitais, apresentações teatrais, e também é utilizada como sinônimo para desempenho ou atuação. Para Zumthor (2000), a performance é entendida como uma dupla ação entre emissão e recepção, cujo foco recai sobre os atores cujos atos performáticos são intermediados por elementos como voz, gestos, mediações, bem como por suas interpretações. E o ouvinte engajado na performance contracena, conscientemente ou não, com o intérprete e com o texto, e nesse processo comunicativo é estabelecida uma relação de reciprocidade e interação entre intérprete, texto e receptor. Simon Frith (1996, p. 203-204) também valoriza o papel da recepção, entendendo que "enquanto ouvintes, nós performatizamos a música para nós mesmos”. E corpos envolvidos na performance da música mimetizam e se envolvem de acordo com "as convenções de comportamento indexadas pelo gênero musical em questão”. (LIMA, 2007, p. 73)

Essa performance acionada na conveniência do baile de soul, na noite do final de semana, no momento de lazer - portanto, de caráter fluido e transitório -, está implícita no estilo e dramatiza uma identidade realizada na 
linguagem, na subjetividade e na comunidade. Ao mesmo tempo em que a lógica performática identitária é calcada nos processos de subjetivação efêmeros e líquidos da subjetividade contemporânea, ela encontra certa coerência em contextos de enunciação e situações comunicacionais. A performance atualiza o corpo e nele inscreve os processos de identificação, criando um efeito de presença das encenações e vivências dos discursos. Na dimensão performática, corpórea e material, são materializadas as identidades que conformam os estilos. Estilos que se baseiam na exposição pública de linguagens, nos gestos, nas sensibilidades em que se inscrevem, nas identidades e em "[...] um corpo em ação gerando uma camada sensível sobre a qual repousam crenças. Por isso a noção de movimento - e o contínuo entre performatividade e performance - na base de ligação entre indivíduos". (JANOTTI JUNIOR; SOARES, 2014, p. 10) Cabe aos atos e experiências performáticas, pois, o momento de partilha do sensível, e o cinema da época foi responsável por uma ancoragem desses sentidos e sensibilidades para a juventude black.

\section{Black movies}

Filmes como Shaft, Super Fly ou o documentário Wattstax fizeram sucesso na cena da Black Rio, bem como outros filmes americanos do gênero cinematográfico blaxploitation. Muitos desses filmes eram frequentemente exibidos antes de alguns bailes, seguidos por debates, ou imagens e clipes eram projetados em telões, servindo como pano de fundo e um acompanhamento visual para as músicas tocadas nos bailes.

Há quem viva apenas de exibir esses filmes antes dos bailes soul. Quem os têm pode pedir qualquer preço, mercado aberto à especulação. O conhecido Messiê Limá, (branco), que detém também filmes sobre artistas negros particularmente importantes para o Soul Power (Marva Whitney, Mongo Santamaria e outros) ganha, segundo Nirto, um dos donos da equipe Soul Grand Prix, que o contrata para essas exibições, Cr\$ 500,00 em cada apresentação. Segundo um outro componente da equipe, Limá ganha, na verdade, Cr\$ 1 mil 500 e segundo os seguidores habituais dos filmes e alguns amigos 
de Messiê Limá, ele ganha de Cr\$ 2 mil a Cr\$ 3 mil. (FRIAS, 1976, p. 4)

Wattstax nunca foi exibido comercialmente no Brasil, mas esse documentário teve uma importância fundamental para a juventude negra da época, não só por seus longos números musicais, mas por mostrar um retrato vívido da maneira como negros americanos se vestiam, dançavam e se comportavam. Outros filmes, como Claudine (1974), com músicas de Gladys Night e Curtis Mayfield; Melinda (1972), sobre a vida no Harlem; O chefão de Nova Iorque (1973), com músicas de James Brown e cujos vilões eram os brancos; Slaughter (1972), com Jim Brown e músicas de James Brown; e Black Samson (1974), sobre a violência nas ruas, integraram o movimento cinematográfico blaxpoitation e criaram uma marca para o gênero.

A estética cinematográfica do blaxploitation pretendia representar a realidade das comunidades negras urbanas americanas, também simbolizando o momento de luta pelos direitos civis e contra a segregação racial dos anos 1970. Os filmes também se baseavam no mote "negro é lindo" e apresentavam novos padrões de beleza, moda e comportamento, em oposição à hegemonia da estética "branca" hollywoodiana. E, de fato, o ápice do blaxpoitation coincidiu com a decadência de grandes estúdios de Hollywood, atraindo novas plateias para os cinemas. Muitos conglomerados do cinema americano estavam à beira da falência e, como solução, abriram suas portas para filmes independentes de baixo orçamento, mas com temáticas diferenciadas e roteiros criativos. Os primeiros filmes blaxploitation foram um sucesso e incentivaram os estúdios a produzir mais de 200 filmes do gênero até 1975, estimulando inclusive produções independentes. A produção em série levou também à realização de películas de gosto duvidoso e de menor orçamento, como as comédias escrachadas Black Dracula, Black Shampoo, Black Lolita e até mesmo Black Gestapo.

Em geral, esses filmes tinham baixos orçamentos, mas geravam muito lucro, tornando-se sucesso rapidamente, como Sweet Sweetback's Baadasssss Song (1971), dirigido e protagonizado por Melvin Van Peebles, um dos filmes seminais do gênero. Super Fly, de Gordon Parks Jr. - mesmo diretor de Shaft -, lançado em outubro de 1972, superou as bilheterias de O poderoso chefão, 
de Francis Ford Coppola, naquele mesmo ano ${ }^{1}$ - e inspirou o lançamento de The black godfather, em 1974, uma versão negra de O poderoso chefão. Além de mostrar a realidade dos guetos, os filmes em sua maioria, possuíam elencos formados por atores negros em papéis protagonistas - os brancos, quase sempre, quando apareciam nos filmes, interpretavam vilões ou antagonistas - e eram também dirigidos e produzidos por afro-americanos.

O cinema blaxploitation também ficou marcado por filmes policiais protagonizados por anti-heróis violentos e mulherengos, que agiam nos limites da moralidade e da lei, mas que também eram carismáticos e bem-humorados, ganhando humanidade e representando hábitos e costumes dos bairros negros. Gírias e palavrões faziam parte dos diálogos, que também ganharam protagonistas negras interpretadas por atrizes de beleza e sensualidade notáveis, como Pam Grier (Foxy Brown, 1974) e Tamara Dobson (Cleópatra Jones, 1973). Com a consolidação do gênero, a produção cinematográfica blaxpoitation aumentou, abrindo espaço para a produção de filmes de outros gêneros tendo negros em papéis principais, como comédias, faroeste e mesmo obras com temática de realismo social. ${ }^{2}$ Os filmes também reservavam lugar especial para a música, e as trilhas sonoras compostas por artistas famosos representavam um atrativo a mais. James Brown fez a trilha de $O$ chefão do gueto, Curtis Mayfield foi responsável pela música de Super Fly e Isaac Hayes ganhou um Oscar com a canção-tema de Shaft.

Os cabelos afros imensos, as calças boca de sino, cores psicodélicas, os sapatos plataforma para homens, os decotes profundos, vestidos justos e

1 O sucesso de Super Fly se deu mais pelo boca a boca do que por uma campanha promocional do estúdio, o que foi um feito surpreendente para a época. O filme contava a história de um traficante que conseguia enganar a máfia, e o estilo do protagonista marcou época. O slogan do filme era "He's got a plan / To stick it to the Man" ("Man" aqui significava o "Cara", que se referia aos brancos americanos), e a frase passou a ser adotada por jovens negros em todo o país.

2 No Brasil, os principais filmes blaxpoitation que aqui foram exibidos, como Shaft, fizeram sucesso, mas não chegaram a influenciar cineastas. $O$ único diretor que chegou a realizar um filme com ecos do blaxpoitation foi Waldir Onofre, um diretor e roteirista negro, em As aventuras amorosas de um padeiro (1975). O filme independente, de orçamento bem modesto, foi rodado em Campo Grande e chegou a obter um surpreendente sucesso nos cinemas nacionais. Apesar de apenas um dos protagonistas ser interpretado por um ator negro (Haroldo de Oliveira), o filme explorava relacionamentos inter-raciais e o humor, retratando a vida nos subúrbios, flertando também com as pornochanchadas do período. 
minissaias para mulheres, que ostentavam longos cílios postiços e maquiagem forte, ressaltavam uma estética negra e criavam a linguagem visual do blaxpoitation baseada no lema "say it loud, I'm black and I'm proud". Era uma exibição pública da aparência que contrariava a invisibilidade imposta à comunidade afro-americana e à beleza negra. Os filmes eram marcados por cenas em que personagens negros humilhavam ou maltratavam seus antagonistas brancos, pelo uso de uma linguagem baseada em gírias e palavrões e ainda pela exibição de cenas de sexo irônicas ou mais explícitas, além de mostrar relações inter-raciais. Muitos roteiros também faziam frequentes referências e denúncias contra o racismo e contra a corrupção - especialmente da polícia branca institucional-, mostrando criminalidade e pobreza, eventualmente até endeusando marginais, como cafetões e traficantes. Por mais que os filmes blaxploitation reiterassem a representação de alguns estereótipos ligados aos negros, como a violência, a imoralidade e a sexualidade selvagem, ${ }^{3}$ bem como um privilégio ao excesso, representado no exagero das roupas, dos carros e armas, essas imagens ecoavam o contexto da época, e esse conjunto simbólico soava bastante subversivo, em matéria de contestação de um regime estético e comportamental hegemônico, mesmo que mantivesse o viés consumista do american way of life. A imagem dos negros nesses filmes não era subserviente ou passiva, e nessas representações cinematográficas, "o negro se torna dono da supersexualidade que o estereótipo lhe atribui. Sua macheza lhe possibilita nunca abaixar a cabeça para o branco" (SOVIK, 2009, p. 24), dotando de positividade os atributos negativos. Na década de 1980, o gênero perdeu força, mas serviu para dar visibilidade a atores, diretores e compositores negros, ajudando na divulgação mundial do soul e do funk.

A fórmula do blaxpoitation fez sucesso em outros países e contextos segregados por propor uma nova representação da negritude, mesmo que acionando algumas ideias que poderiam ser compreendidas como pejorativas, mas que foram reapropriadas de modo a positivar os atributos "negros".

3 Não só nas cenas, mas as trilhas sonoras também colaboravam para a afirmação de símbolos associados às representações do negro propostas pelos filmes de blaxpoitation em relação à sexualidade do homem negro. Uma das frases da canção-tema de Shaft, composta e interpretada por Isaac Hayes, dizia: "Who's that private dick who's a sex machine to all the chicks? SHAFT!" ("Quem é aquele pinto secreto que é uma máquina de sexo para todas as garotas? SHAFT!”). 
Mesmo que muitas das histórias girassem em torno de cafetões, traficantes, gângsteres e criminosos, geralmente eram personagens sensuais e charmosos, superdotados. Shaft rompia um pouco com essas características e, ao contrário, propunha um herói clássico negro, que buscava a justiça e agia dentro da lei, o que o tornou mais atrativo para um público mais amplo. Os filmes incorporavam atores jovens e propunham uma linguagem contemporânea, com gírias e expressões coloquiais usadas nas ruas, colocando a condução das tramas e os cenários das narrativas nos guetos e áreas pobres da cidade. Mesmo assim, a profusão de figurinos usados nos filmes representava a última moda da época, ligados a elementos de uma estética afro-derivada, que demonstravam uma valorização do consumo e do próprio corpo. As cenas de violência e sexo também davam um tom mais contemporâneo e libertário para os filmes, atraindo audiências mais amplas e priorizando a ação em detrimento do drama, o que concedia aos protagonistas uma posição de poder.

\section{Moda e consciência}

A consciência veio como moda Jorge Watusi ${ }^{4}$

De forma geral, tem-se testemunhado na contemporaneidade o sucesso de gêneros musicais e artistas na indústria fonográfica cuja estética e discurso têm ido além dos eventos musicais, chegando a atitudes, práticas de consumo e vestuário que englobam "toda uma gama de estratégias de identificação através do consumo de bens desenvolvidos e divulgados para o público jovem”. (TROTTA, 2006, p. 34) O rock and roll foi um dos primeiros gêneros a demarcar um mercado jovem nos anos 1950, em que a roupa circunscrevia tanto uma moda derivada da música quanto um estilo que definia um pertencimento a um grupo, determinando valores e gostos. As diferentes estéticas das modas que acompanham os gêneros musicais reforçam os diferentes

4 Jorge Watusi, bailarino negro baiano. Ver citação em Risério (1981, p. 31). 
estilos a partir da fixação de suas marcas no vestuário, comunicando e expressando aspirações, reforçando os ideais de cada época.

Nos anos 1970, a moda se diversifica e se voltava para a satisfação de necessidades de distinção e diferenciação, mas em signos menos elitistas, cujos valores buscavam demonstrar mais informação, criatividade individual e capital cultural do que econômico. Surge também uma nova relação do indivíduo para com a moda: no lugar da roupa representar status ou classe social, ela passa a ser parte da elaboração de uma imagem pessoal, o que gera a criação de vários focos criativos e referências estéticas diversas. Essa moda refletia também algumas demandas e era pautada pelos movimentos culturais e sociais desencadeados nos anos 1960, como o movimento hippie, o feminismo, o movimento gay e os movimentos negros e pelos direitos civis, que se articulavam a uma cultura jovem que questionavam o status quo. "Essa fragmentação do sistema traz consigo as modas jovens: modas marginais que se apoiam em critérios de ruptura com a moda profissional" (HELLMAN, 2009 , p. 35) e que se abriam a interpretações pessoais de cada consumidor, incorporando traços de estilos de diferentes grupos sociais e culturais.

O jeans, um tipo de tecido originalmente utilizado para roupas de trabalhadores em minas, democratizou o acesso às tendências, quando estar na moda não significava mais ser elegante e tinha mais a ver com causar impacto emocional e simbólico. A novidade não vinha mais das elites e da alta costura, mas sim da moda das ruas, que incorporavam novos valores de consumo e ideais igualitários, mas também aspirações individualistas. O mundo dos esportes gerou inovações na fabricação de tecidos, mais elásticos, flexíveis e que demarcavam o corpo, explorando outras sensualidades. A arte moderna e a Pop Art, de cores fortes e contrastantes, desenhos geográficos e abstratos, valorizavam uma moda hedonista, libertária, irônica e espontânea, materializando nas roupas uma cultura do excesso e do exagero, como nas mangas bufantes, calças com amplas bocas, babados, cores fortes, lapelas pontudas, decotes profundos, brilhos e texturas.

A moda black, de certa forma, incorporava essas novidades, mas ainda valorizava uma elegância e uma preocupação com a indumentária como uma forma deliberada de diferenciar a juventude black, por exemplo, dos "cocotas”, gíria da época que se referia inicialmente às meninas adolescentes e 
passou a designar os jovens de classe média que curtiam o rock e a praia, em parte influenciados pelo movimento hippie e pela contracultura, mas também pela recente cultura surf: "cocota e cabelo para fina [sic] não é com a gente”, declarou um entrevistado frequentador dos bailes soul a Frias (1976, p. 4). Existiam também os "bailes de cocotas", que tocavam as últimas novidades do rock, divulgadas por rádios jovens como a Tamoio, a Mundial, a Rádio Ipanema e a América. Essas festas também tinham suas equipes de rock, como a equipe Khaunna, Sons e Efeitos, Jet Rock, The House of Rock, Concepção Erótica, e os bailes de Big Boy também atraiam os cocotas. Os ícones nacionais desse grupo eram as jovens atrizes Lídia Brondi e Glória Pires, por conta do sucesso de suas personagens na novela Dancin' Days (1978). "Os cocotas iam pros bailes de rock do subúrbio, tinham cabelo parafinado, visual meio surfista, usavam calça com o rego aparecendo. O negócio deles era só diversão", relembra o DJ Marlboro, que frequentava os bailes de soul, mas se destacou no circuito do funk nos anos 1980. (SCHPREJER, 2009) A "calça cocota" se referia a um modelo de jeans com a cintura bem baixa, justa nos quadris, geralmente com a boca mais larga. Os rapazes podiam ter cabelos longos, e os frequentadores da praia começavam a usar cabelos parafinados (FRIAS, 1976), ${ }^{5}$ que davam um tom aloirado às madeixas. A informalidade dos cocotas era oposta ao visual dos blacks, que eventualmente buscavam uma aparência mais formal e sofisticada ou uma apresentação mais exuberante e cheia de detalhes, cuja composição dos elementos compunha o ritual de preparação para a noite do baile, buscando um diferencial e um maior destaque. O jovem Hélio de Oliveira, então com 22 anos, que trabalhava como contínuo, narra para Lena Frias como se dava essa preparação:

5 O entrevistado Edson M. S., estudante de 16 anos, descreve para Frias (1976, p. 6) a visão pejorativa que os cocotas tinham entre os blacks: "A rapaziada que é mesmo da cor, que tem esse preconceito com eles, nem entra em festa de roqueiro. Roqueiro é cocota, white é drogueiro. Tem uns pretos que botam umas calças cocota e vão pra lá dizer que também são, mas eu acho que não pega bem pra eles. Será que eles não veem que o cabelo deles é duro também? Acho que eles queriam ter aquele cabelo de parafina, lisinho, caído pros lados! White tem é inveja do cabelo da gente, porque não pode fazer igual”. 
a gente bota uns óculos escuros, um chapelão, um paletó diferente, lascado atrás, um terno branco e uma gravatinha borboleta, um casacão até o pé. Fica chamando atenção. É como a gente gosta. Calça tem que ser de boca estreita, na cintura, nada de calcinha de cocota. (FRIAS, 1976, p. 1)

Uma moda black, principalmente a que apareceu no Rio de Janeiro nos anos 1970, oscilava entre a influência dos cantores e artistas negros dos EUA e a incorporação de alguns elementos de várias estéticas africanas. Criada especialmente para enfatizar as performances na pista dos bailes, que logo alcançou as ruas, a moda dos blacks, em um primeiro momento, se propunha a reproduzir o visual dos cantores de soul mais famosos, como Isaac Hayes e, especialmente, James Brown. Esse estilo se baseava na encenação de uma estética e de uma beleza negra ideal, de acordo com alguns padrões de consumo cultural globalizado, com base na cultura afro-americana. "Começamos a ditar moda [...]. O que a gente via acontecer no Harlem, a gente começava a jogar para cá”, relembra Nirto em depoimento a Essinger (2005, p. 24), um dos donos da equipe SGP. Quanto mais elaborada a roupa, mais próxima ela estava da indumentária dos ídolos negros americanos, o que enfatizava o acesso a diferentes informações e a criatividade individual, além de ostentar um certo poder aquisitivo que concedia aos participantes da cena black um capital cultural e simbólico distintivo. A moda black, assim, mantinha um compromisso significativo com a juventude negra suburbana, mas estabelecia também um diálogo com os valores da classe média, de cujas referências os participantes ora se distanciavam ora se aproximavam.

Para se distinguir por meio do visual, muitos se inspiravam nas capas bordadas e veludos brilhantes de cores berrantes como as usadas por James Brown, ou modelos que imitavam a capa de Rufus Thomas no filme Wattstax, vermelhas, até à altura dos joelhos. O terno ou traje mais social, especialmente no contexto dos bailes black, caracterizava uma forma de inserção dentro de um modelo aceito socialmente, mas sem deixar de afirmar uma diferenciação. Nesse ato de adaptar, traduzir e atualizar peças de vestuário que inicialmente eram utilizados por grupos de maior poder aquisitivo, havia uma apropriação cultural lúdica e irônica que propunha uma inserção, mesmo que transversal, a uma estética e a um mercado de consumo massivo 
de bens culturais. Muitos ostentavam ternos vistosos, chapéus de aba larga e joias como anéis, correntes e relógios, inspirados pelo visual de gângsteres dos anos de 1930 e 1940 e dos cafetões negros (pimps) americanos, como revela o cantor Gerson King Combo em depoimento a Essinger (2005, p. 25): "Eu era um dos crioulos mais bem caracterizados, com capa e chapéu de lontra, aquele visual do cafetão americano”. Sobre as apresentações do cantor, Essinger (2005, p. 40) dá mais detalhes:

Chegava ao baile em carros de luxo da época, como Dodge Dart, Galaxy e Mustang, e levava um entourage 'de 21 crioulos' - entre eles os músicos de sua banda (a União Black), um auxiliar de palco, um mordomo (para trocar suas roupas ao longo do show) e seis seguranças (três de cada lado do palco).

Gerson King Combo também copiava, deliberadamente, os passos do ídolo James Brown, que usava uma longa e brilhante capa de cetim ou veludo e também trocava de terno inúmeras vezes no palco, tornando suas performances ao vivo uma experiência inédita musical e também visual. ${ }^{6}$ Os artistas de soul, nos anos 1960, costumavam utilizar roupas mais formais, seguindo o padrão estético dos cantores brancos norte-americanos do pop e do rock'n'roll. Ternos bem cortados, ajustados, em tons sóbrios, vestidos longos e sensuais para as mulheres eram usados no intuito de tornar os cantores negros mais "palatáveis" para o público branco. A elegância, o luxo e o glamour nos trajes se tornou uma estratégia bastante utilizada pela Motown, que investia em fórmulas musicais mais comerciais e populares e tentava trabalhar a imagem dos seus artistas nesse sentido. James Brown também usava ternos e roupas sociais no começo de sua carreira, mas preferia ostentar calças bem mais apertadas do que o usual na moda da época. Em suas apresentações, acompanhado pelo trio vocal The Famous Flames, é possível perceber a modelagem mais ajustada nas pernas e de comprimento mais curto

6 O apuro com a própria indumentária, bem como com o visual da banda que o acompanhava, foi a marca da trajetória midiática de James Brown. Conta-se que se um dos músicos não estivesse com os sapatos devidamente engraxados e brilhantes para o show, deveria pagar uma salgada multa ao cantor. 
quando comparada à das calças dos outros cantores. A ideia era que as calças não atrapalhassem os passos velozes, valorizando os movimentos e também chamando a atenção para as pernas, como forma de ressaltar as formas corporais e criar uma imagem mais viril e sensual para o cantor.

Nos bailes, as calças mais curtas e ajustadas, com a boca mais estreita (BAHIANA, 2006, p. 304), também eram uma preferência entre os jovens frequentadores, ao contrário das célebres calças boca de sino, que marcaram a década de 1970, um ícone das discotecas e também do movimento hippie. Confeccionadas em tecidos associados a uma ideia de elegância, como linho, brim ou tergal, as calças vincadas e bem passadas demonstravam qualidade da roupa, apuro e cuidado com a aparência, mesmo que tivessem cores fortes ou fossem combinadas com peças coloridas e chamativas. O jeans começava a se popularizar e era sinônimo de lazer, descontração e juventude, se tornando primeiro moda entre os adolescentes de classe média, para depois chegar aos bailes. As calças jeans mais desejadas eram as da marca americana Lee, que só eram achadas no Brasil via contrabando de revendedores e, apesar do alto preço, viraram febre; naquele tempo, se dizia "calça Lee” no lugar de calça jeans. Dom Filó, inclusive, conseguiu fazer algum dinheiro revendendo calças Lee compradas no câmbio negro. A modelagem americana, no entanto, não se adequava ao gosto e ao padrão de corpo brasileiro, e era preciso ajustar algumas partes da calça em costureiras, especialmente na região da boca, e, no caso dos modelos femininos, eram apertados na parte de trás, a fim de ressaltar e valorizar os glúteos.

Mesmo que o estilo dos blacks não se baseasse em uma apropriação direta de traços culturais nacionais, já que era inspirado na moda das ruas nova-iorquinas e refletia a escolha de uma nova aparência, "capaz de negar simultaneamente o surrado traje do malandro carioca e o uniforme colonial das escolas de samba" (BLACK RIO, 1978, p. 154), é interessante notar que, nos anos 1920 e 1930, o uso de calças de boca estreita era um costume negro, usada por malandros e capoeiristas, da mesma forma que a preocupação com a elegância. A boca mais estreita das calças, segundo Noronha (2003, p. 134), impedia que, na luta, o malandro fosse derrubado pelas pernas. $\mathrm{Ou}$ seja, o modelo de calça demarcava uma afiliação a uma identidade específica e a um certo tipo de comportamento tido como marginal e, portanto, chamava 
a atenção da polícia, que prendia qualquer indivíduo que usasse esse tipo de roupa, somada a outros elementos da indumentária. ${ }^{7}$ Da mesma maneira, calças boca de sino também não eram favoráveis à performatização dos passos de dança na pista, pois eram mais justas na perna, e modelos mais folgados eram mais confortáveis para a performance dos bailarinos. E, mais importante, as calças de maior comprimento poderiam ocultar os sapatos, que mereciam destaque na cena dos bailes. ${ }^{8}$

Os sapatos tinham importância fundamental no contexto do Black Soul. Chamados de pisantes ou "cavalo de aço", esses calçados eram inspirados nos sapatos plataforma, com saltos grossos e altos, ou possuíam solas com várias camadas, "andares". O nome "cavalo de aço" pode também ter sido adotado como referência à novela global de mesmo nome, exibida em 1973, na qual o personagem interpretado pelo ator Tarcísio Meira usava sapatos de grossas solas de borracha. Pisantes coloridos ou brancos, mas o mais comum eram os coloridos, de tons contrastantes - "rosa, rosa e roxo, amarelo ovo, verde-limão, azul e creme, lilás, todas as combinações imagináveis” (FRIAS, 1976, p. 5), o que também levou a outro apelido para esse modelo de calçados: "salada de frutas". Quanto mais altos, mais o bailarino se destacava em meio à multidão dos bailes. Não eram muitos os lugares onde esse modelo específico de sapato poderia ser encontrado, e os locais mais famosos (talvez os únicos) que confeccionavam esse tipo de calçado eram duas lojas: a sapataria Pinheiro, na Galeria São Luiz, em Madureira, e a loja do Sousa, no centro da cidade. Nessa composição, os sapatos, que eram bastante caros, deveriam ser

7 A roupa ajudava a manter a identidade do grupo de maltas de capoeiras que eram comumente vistos "usando calça larga de boca fina (a chamada calça boquinha, com bolso muito fundo, no qual cabiam fumo, dinheiro, cartas e a navalha), paletó sempre aberto, botina bico bem fino e lenço no pescoço. Este lenço, ou mesmo a camisa, devia ser de seda, já que, segundo corria nas ruas, o tecido cegava o fio da navalha. A roupa era sempre branca, porque traria marcadas as quedas no chão da rua". (NORONHA, 2003, p. 114)

8 Dom Filó, em entrevista a a Ribeiro (2008, p. 168), explica: "O visual do Black tem todo um sentido. E por que a calça era apertada? Exatamente para aparecer o sapato. Sendo boca sino era apertada, era difícil de colocar, pois era uma calça muito justa para passar o movimento das pernas, para mostrar o brilho das pernas. Ali você identificava o dançarino e na hora de dar o 'espaguete' que é quando você abre as pernas e dá o 'espaguete', tem todo um contexto, na dança e na expressão da roupa". 
impecáveis, envernizados, brilhantes. ${ }^{9}$ "Porque a parte mais importante do black era o sapato. Era o 'tchan'. Não existia tênis na época. Ninguém ia de tênis. Então você tinha que fazer um sapato. Ele era feito sob medida, duas cores, três cores e, geralmente, em verniz", conta Dom Filó em entrevista a Ribeiro (2008, p. 168).

$\mathrm{Na}$ época, calçados, ainda mais sob medida, não eram itens de valor muito acessível, mas os jovens se esforçavam para adquirir os sapatos, que, inclusive, favoreciam uma melhor performance durante a execução dos passos de dança. "Meu sapato? Custou Cr\$ 250,00. Eu ganho salário. Mas eu tenho um mais bonito, de três andares. O pessoal sabe que eu me amarro e me deu de aniversário. Eu nem pude falar. Eu fiquei tão feliz...”, conta um jovem morador da favela Dona Marta, em Botafogo, balconista de farmácia para Lena Frias (1976, p. 5). Solados de couro facilitavam o deslizamento na pista, mas também faziam uso do recurso de fixar chapas de metal no solado, na região do salto e da frente do calçado - por isso, "cavalo de aço" -, que ajudavam a movimentação e facilitavam os giros quando em contato com o chão liso, relembrando comentário de Risério (1981, p. 28):

O pessoal escrevia firme nos salões, envergando o traje típico da onda, cabelo ouriçado sob boné ou chapeuzão, calça de cintura alta e boca larga, camiseta de lastex, sapato, digo, pisante colorido, de nome 'cavalo de aço', salto altíssimo, com uma chapa de metal no bico e outra no salto, de modo a melhor deslizar em ágeis e desconcertantes passos de dança, a exemplo do chamado 'agilidade no sabonete', em si mesmo um minishow filigranado de virtuosismo rítmico e corporal.

Confeccionar peças sob medida, customizar, modificar e personalizar eram práticas habituais dos jovens para tentar seguir a moda da Black Rio. Recorrer a costureiras e alfaiates era comum e, como conta Ras Adauto em

9 “Os pisantes de dois, três, quatro andares, feitos à mão, modelos especiais, custam de $\mathrm{Cr} \$ 250$ a Cr\$600 nas lojas do Sousa e do Pinheiro, no centro da cidade e em Madureira; só a filial do Pinheiro na Galeria São Luis, em Madureira, está vendendo, por semana, cerca de 500 pares de sapatos especiais para os black". (FRIAS, 1976, p. 4) 
entrevista à autora - concedida em 21 de fevereiro de 2016 -, a família ajudava bastante: "Quem costurava minhas roupas era minha mãe. [...] Muitas das roupas as próprias pessoas inventavam, e surgiram modistas e estilistas com as suas modas black". Para ficar na moda e usar as famosas calças boca de sino, Oziléia Souza mandava colocar nesgas nas calças. "Ficava muito mais barato, a gente não podia comprar roupa nova sempre, e reaproveitava peças usadas". Dom Filó, em entrevista concedida a Ribeiro (2008, p. 163), também comenta que muitos usavam camisetas de malha rudimentarmente pintadas à mão, com imagens copiadas das capas dos discos de soul ou até mesmo com frases que reportam ao movimento negro norte-americano, como "Black is Beautiful". "Você tinha na época, muito pouca opção de roupa. Não tinha silk screen, não tinha nada. [...] Eles pintavam aquelas camisas coladas no corpo, que eram malha Hering mais baratas”. Outra opção frequente era personalizar as roupas de maneira criativa:

As roupas, de um modo geral, são de tecido barato, pois as despesas com os sapatos não deixam muita margem a luxos complementares por parte da população Black carioca, constituída, em sua grande maioria, de bagageiros, contínuos, entregadores, balconistas, ambulantes, biscateiros, auxiliares de escritório, empregadas domésticas. Exóticos, isto sim: velhos paletós bordados com frases-chave da soul music (os black sabem tudo sobre o soul, detalhes históricos, épocas de lançamentos de discos, de conjuntos e cantores norte-americanos; sabem tanto de soul quanto ignoram de cultura brasileira), camisetas toscamente pintadas a mão, chapéus, óculos escuros em modelos americanos, coletes, bengala como complemento. (FRIAS, 1976, p. 4)

A confecção e customização de roupas em casa com tecidos comprados em lojas populares, assim, tornou-se a solução mais comum e já era uma prática bastante difundida entre as classes mais baixas, visto que roupas de lojas de departamento e butiques eram caras. As pessoas tinham menos opções de consumo, menos peças em seus guarda-roupas, e a utilização de acessórios diversos dava um tom mais diversificado e moderno ao visual, como óculos escuros, coletes, gravatas borboletas, suspensórios, bengalas e chapéus, que 
ajudavam a dar destaque os bailarinos na pista de dança. O Jornal do Brasil assim descreve a indumentária dos frequentadores de um baile realizado em 1976: "roupas as mais exóticas, que incluíam casacos feitos com chenile, veludo ou peles e velhas capas de chuva, de xantungue, improvisadas em capotes; e toucas de banho, de plástico e coloridas, usadas a modo de boina ou boné”. (O SOUL..., 1976, p. 20)

"O resultado são fantasias individuais sempre renovadas, roupas descobertas no fundo de algum baú, ou acessórios adquiridos em lojas tão prosaicas e óbvias como as da praça da Bandeira”. (BLACK RIO, 1978, p. 154) Para Risério (1981), a utilização do artesanato e da customização de roupas e acessórios, além da combinação de diversos elementos, pode ser compreendida como uma reação consciente contra a indústria, comércio e tecnologia, em que se buscava uma moda mais individualizada, singular, não padronizada em relação aos modelos prontos de fábrica, uma tônica da moda dos anos 1970. A ideia era se opor a uma "gramática" imposta pelo capitalismo, aumentando possibilidades de combinações e criatividade. Ao mesmo tempo, representava o desejo de ingressar em uma moda a partir de soluções alternativas mais baratas a um público de menor renda. "O surgimento marginal de novos estilos vestuais, até que estes eventualmente venham a ser absorvidos pelo circuito industrial, implica, necessariamente, no recurso à prática artesanal, ao fabrico doméstico de roupas”. (RISÉRIO, 1981, p. 102)

Porque a partir de determinado momento a gente começou a criar a nossa própria maneira de vestir. Que era muito elegante. Porque era uma roupa que batia com a gente. Diferente de você chegar ali e comprar uma roupa numa butique. Era diferente você comprar uma roupa numa loja. Você fazia a sua roupa. A calça vinha na sua medida, o sapato vinha na sua medida, os sapatos eram umas obras de arte porque eram sapatos com tom sobre tom que eles chamavam de salada de frutas. ${ }^{10}$ (RIBEIRO, 2008, p. 161)

Ao final da década, alguns empresários, de olho no sucesso do soul, decidiram investir na moda black, como contou Mauro Taubman, estilista e

10 Depoimento de Mr. Funky Santos. 
dono da marca Company, em novembro de 1978: "Abrimos um departamento especial para vender a moda black e aos poucos lançaremos roupas bem sensuais em tecidos aderentes". (BAHIANA, 1980, p. 49) Mas as iniciativas acabaram sendo frustradas e as estratégias de marketing tiveram que ser redirecionadas com o declínio da cena soul e a ascensão da discoteca no cenário musical carioca. De qualquer sorte, a moda black reproduzia parâmetros do universo fashion mundial, bem como da cultura jovem da época, que valorizava o corpo e o realce das formas, especialmente com a utilização de tecidos sintéticos como o veludo, nylon, elastano e lycra. Especialmente o poliéster se tornou bastante popular, pois era mais barato e foi muito usado na confecção de camisas de botão, de modelagem mais ajustada, com golas pontudas e estampas floridas, psicodélicas e geométricas, utilizada por homens e mulheres.

A década de 1970 também foi marcada pelo crescimento da moda unissex, que correspondia a um sentimento da época ligado a idealismos, contestação social e transformações, com ênfase na questão da igualdade de gêneros. Apesar da frequência dos bailes ser predominantemente masculina (BLACK RIO, 1978, p. 154), o estilo soul chegou a homens e mulheres, em que ambos poderiam usar as mesmas roupas, em especial calças e ternos de corte mais acinturados. Havia ainda os macacões - chamados de peça única -, popularizados por James Brown, geralmente de cores fortes e modelagem justa, e, a exemplo do astro, os blacks usavam a peça aberta na parte superior, deixando o tórax à mostra. Havia uma deliberada exibição do corpo e da sensualidade, como forma de exercitar novas sexualidades, especialmente no caso dos homens. Risério (1981, p. 104) relembra que, naquele momento, homens começavam a retomar o interesse pela estética, pela moda e beleza, com a marca do exibicionismo e da expressividade corporal, com certo apelo erótico, especialmente no caso dos jovens negros, assim como os hippies na década passada.

É interessante notar que, enquanto o diferencial das mulheres que frequentavam a cena black era a utilização de roupas típicas do guarda-roupa masculino, os homens se permitiam uma estilização maior, ostentando visuais menos discretos - especialmente em oposição às roupas de trabalho -, com brilhos, brocados, texturas e cores diferenciadas e modelagens justas, 
marcando o corpo, o que, até então, era uma estética mais associada à moda feminina em geral. Os ternos brancos foram reapropriados da tradição dos malandros, enquanto paletós e sobretudos longos e bem cortados já faziam referência direta a uma noção de elegância burguesa reconfigurada no processo de ascensão econômica dos negros americanos. "Eles se sentiam gente, se sentiam maravilhosamente gente, porque nunca se usou terno e gravata, não tinha oportunidade”, como relembra Gerson King Combo em depoimento a Rita Ribeiro, (2008, p. 161). O terno e a gravata, no contexto da cena black, mesmo em cores vibrantes e detalhes que tendiam a um exagero, era uma forma de distinguir o traje do tédio do mundo cotidiano do trabalho, mas, ao mesmo tempo, emulava a possibilidade de ascensão social, justamente ao usar um tipo de traje que não era utilizado em suas vidas diárias - o terno do executivo, do advogado, do businessman.

Falando sobre o surgimento dos estilos negros, há similaridades nesse tipo de construção tanto no contexto brasileiro quanto norte-americano. Ostendorf (2000, p. 219) lembra como as vestimentas negras, durante a escravidão, possuíam características como o uso de cores brilhantes e "descombinantes”, justaposição de peças de roupas e a tendência à criação de um modo de vestir que não buscava a discrição, mas chamar a atenção. Essas características, segundo o autor, invocavam possíveis tradições de costumes da África Ocidental, combinados com tendências especificas da experiência diaspórica no Novo Mundo, em que mostrar o que se possuía e chamar a atenção quando em público era uma forma de expor um certo capital simbólico ou até mesmo posses materiais. As sociedades escravocratas davam à roupa, assim, uma função cultural sobredeterminada, pois as transgressões sociais por meio da vestimenta "adquiriam um significado existencial político e uma urgência social” (OSTENDORF, 2000, p. 219) e até mesmo ofereciam uma possível sensação de liberdade - como o que ocorre durante o carnaval, por exemplo, em que fantasias luxuosas encenariam outros modos de existir.

Há semelhanças entre a experiência negra norte-americana e a brasileira, em que mesmo os mais pobres se esforçavam para ter ao menos uma boa vestimenta que seria usada aos domingos, nas missas católicas ou cultos pentecostais - a "roupa da missa" -, momentos de convívio coletivo de comunidades que se organizavam em torno de rituais religiosos. A roupa e a forma de 
se apresentar publicamente possibilitavam a aquisição de respeito e demonstravam um domínio de códigos sociais que promoviam uma inserção social em grupos variados, demarcando identidades tanto por meio do exagero e da ruptura, quanto pelo exercício de cópia de determinados padrões como forma de imitação das classes de maior poder aquisitivo, em uma tentativa de subversão de hierarquias de cor e classe.

Estar "bem vestido", ao longo da experiência diaspóricas, tinha uma importância fundamental na trajetória da memória da escravidão e pós-escravidão. Usar boas roupas significava ter dinheiro e, portanto, estar longe da marginalidade, da criminalidade e da ilegalidade. Ter uma "boa aparência" se alinhava a uma ideia de inserção na sociedade, no mundo do trabalho, pertencer a uma "boa família", ser respeitador (e respeitado), cumpridor dos seus deveres e, portanto, digno de confiança. Mesmo que na fugacidade de uma festa noturna, usar boas roupas emulava a sensação de pertencer a uma classe mais privilegiada, ou de ser reconhecido como um cidadão dotado de direitos. Ao mesmo tempo, denotava um momento de liberdade e criatividade, quando a opção era pelo choque e pela provocação no visual em relação à homogeneização do cotidiano. Uma oportunidade de se destacar e garantir uma maior visibilidade no espaço da cena: "O maior sonho de cada Black é lançar, isto é, apresentar uma roupa ou um detalhe original no vestir, para ser imitado pelos demais". (FRIAS, 1976, p. 5) Obviamente, a utilização da roupa e da aparência também representava um recurso a mais dentro da "economia da atração" durante a noite, em que a beleza e a criatividade poderiam trazer maiores ganhos em disposições de afetividade e relacionamentos. A ideia era subverter significados dominantes e valorizar traços que, fora daquele espaço, poderiam ser ridicularizados ou causar estranhamento, inspirados em uma estética e em atos de consumo influenciados pela cultura afro-americana. Muitas dessas imagens chegavam a esse público por meio de capas de discos de soul americano, revistas negras e, ainda, através do cinema.

Tanto os astros negros do cinema quanto os líderes dos movimentos políticos inspiravam os jovens blacks cariocas. Dom Filó e os companheiros da SGP usavam um visual totalmente preto, com jaquetas, botas e boinas, inspirados nos Panteras Negras, e circulavam pelas ruas da cidade causando comoção e ostentando "grossos cordões, cabelos volumosos e sapatos de saltos 
bem altos. Para completar, andavam num automóvel Galaxy preto com os vidros escurecidos". (ESSINGER, 2005, p. 30) A exuberância das indumentárias masculinas nos bailes era contraposta ao esmero nos acessórios chamativos, na apresentação dos cabelos e na maquiagem usada pelas mulheres, em tons brilhantes e cores fortes. Inspiradas pelas divas da soul music, como Diana Ross, e por atrizes negras, como Pam Grier, muitas usavam glitter em olhos carregados, grossamente delineados e emoldurados por longos cílios postiços, com sobrancelhas extremante finas, deixando os olhos em destaque. Muitas mulheres chegavam a raspá-las, para redesenhá-las com lápis, levantando o arco da sobrancelha.

Para além das referências americanas, a cultura africana também influenciava a moda black, mesmo que lateralmente. Batas e calças coloridas, com estampas que rememoravam uma arte de estamparia africana, também eram usadas pelos jovens, junto a outros elementos. "Aqui todas as combinações são possíveis, e trancinhas coloridas de contas podem perfeitamente se combinar com uma blusa Fiorucci, assim como abadás caírem levemente sobre jeans”. (RISÉRIO, 1981, p. 104-105) Acessórios como cordões, pulseiras e brincos também marcavam uma estética africana, como a utilização de colares de madeira e marfim e de contas brancas, justos ao pescoço - moda que foi incorporada pelas novelas, quando o acessório passou a ser usado pelo galã e ator Mário Gomes na novela Duas vidas, exibida pela Rede Globo entre 1976 e 1977, na qual interpretava o papel de um cantor. Os turbantes e amarrações com lenços voltaram à moda e foram também incorporados pelas frequentadoras da cena black, combinados com elementos de uma estética jovem contemporânea internacional.

Na Europa, desde o século XVIII, já havia referências ao uso de turbantes, primeiro por marinheiros e navegadores, após contato com os povos do Oriente, mas logo passaram a ser usados pelas damas francesas. Os turbantes foram introduzidos no mundo da moda em meados dos anos 1920, por conta da influência oriental no vestuário da época, introduzidos pelo estilista Paul Poiret. Nos anos 1940, foi a vez de Carmen Miranda trazer o turbante e amarrações apropriados da cultura das baianas negras, influenciando mulheres em todo o mundo e tornando o turbante sinônimo de sofisticação e referência de luxo. Entre os anos 1960 e 1970, uma nova onda da moda étnica 
reintroduziu os turbantes nas passarelas, especialmente reapropriados por Ives Saint-Laurent, inspirado pela cultura do Marrocos e do norte da África.

Historicamente, diversos modelos de turbantes eram usados por diferentes povos ao longo do tempo, como persas, árabes, argelinos, judeus, tunisianos, de inúmeras maneiras, antes da era cristã, sendo predominantes na indumentária masculina. Os turbantes eram utilizados como indicadores de afiliação étnica e posição social - como tribo, casta, reino -, da mesma forma que podiam simbolizar uma determinada religião. Mas podiam ser apenas adereços de moda ou simples proteção contra o sol. No Brasil e na América, os turbantes chegaram por meio da escravidão africana, herança de povos iorubás e malês (muçulmanos), e eram rotineiramente usados com amarrações simples, compondo o traje de trabalho. Nas religiões de origem africana, o uso do turbante se reconfigurou e se tornou uma marca tradicional dos terreiros, ganhando um status simbólico e religioso na umbanda e candomblé, fundamentais territórios de preservação da cultura afro. Assim, os turbantes permaneceram na cultura brasileira como um símbolo de uma africanidade e de uma negritude e foram apropriados nos anos $1970 \mathrm{em}$ um sentido de luta e afirmação racial. Diferentes amarrações de turbantes compunham o visual das mulheres nos bailes.

Pode-se afirmar que a moda soul, como toda moda, mantém uma relação direta e ininterrupta com o costume. Mas, por seu compromisso específico com um grupo étnico em condição minoritária, o diálogo estabelecido é duplo ou, se se prefere, referido a dois diferentes costumes ou tradições. De um lado, a moda soul dialoga com o costume dominante na sociedade envolvente, tomando-o como referência a partir da qual procura se distanciar e diferenciar. De outro lado, ela evoca - e dialoga - com o costume e a tradição nos quais o grupo vai buscar resgatar sua originalidade e o que seria sua autenticidade. (GIACOMINI, 2006, p. 201)

Em um primeiro momento, a indumentária black servia apenas para uma performance restrita à noite e aos bailes. Mas, aos poucos, a exibição pública desse estilo na paisagem urbana se tornou uma forma de anunciar a condição de ser um black e um frequentador da cena também em outros espaços para 
além dos bailes, o que permitia, para Giacomini (2006, p. 199), "de um lado o reconhecimento pelos iguais e, de outro, a afirmação da especificidade junto aos diferentes”. Essa demarcação da diferença no cotidiano, aos poucos, se torna quase essencial para os frequentadores dos bailes, na construção não apenas de performances identitárias, mas também como formas novas de ocupar o espaço público.

Em muitas culturas negras nas Américas, é notável a preocupação com a questão visual e a aparência, que criava uma possibilidade e um sentimento de inserção social em sociedades segregadas, como mencionado anteriormente. Na moda black, o brilho, o exagero, os detalhes não eram operadores de uma mera superficialidade, mas se tornavam fonte de prazer em modos de enunciação e posicionamentos perante o que se considerava bom ou mau gosto e também enfatizavam status cultural da moda, acionando valores relativos à alta e à baixa cultura, ao kitsch e ao chique, em maneiras sofisticadas de comunicar um estilo a partir de produções de sentido diferenciadas. Risério (1981, p. 101) conclui: "A indumentária era, enfim, uma plumagem artificial que se tornava, em si mesma, aviso e manifesto, espécie de fantasia ideológica, símbolo de inconformismo e afirmação de uma distância”. Nesse ponto, a roupa não só integrava os blacks à cidade, mas trazia uma nova marca para a paisagem urbana, a marca da diferença, atravessada por relações de poder e estratégias de visibilidade.

\section{Cabelos politizados}

Uma das formas de dramatização do estilo black residia na apresentação dos cabelos, que davam o tom mais "afro" dessa estética. O penteado, conhecido corriqueiramente como afro ou black, se tornou um instrumento estético baseado na afirmação positiva da ideia do "ser negro", a partir de processos de autovalorização, representação e reconhecimento. (CARRERA; OLIVEIRA, 2013) Nesse contexto, o estilo de penteado black power se referia àquele utilizado por ativistas negros sul-africanos, americanos e brasileiros nos anos de 1960 e 1970, acionado no momento de uma redefinição dos signos de beleza no qual os cabelos afro ou naturais se tornaram uma maneira de construir autoestima e autoconhecimento. (TROTTA; SANTOS 2012) Assim, o 
cabelo assumia centralidade como elemento fundamental na composição do estilo e do visual black, que, pela primeira vez, era usado ao natural, sem alisamentos e com maior volume. No auge do movimento soul, a maioria dos cantores negros, mesmo aqueles não deliberadamente ligados ao funk, haviam aderido ao penteado: de James Brown aos Jackson Five, chegando ao Brasil nas figuras de Tony Tornado, passando por Wilson Simonal, Jorge Ben Jor, Tim Maia, Gilberto Gil - que tingiu uma estrela branca no cabelo. Antes disso, ainda nos anos 1950, artistas como Nina Simone e Miriam Makeba passaram a usar seus cabelos naturais publicamente, dispensando o uso de perucas e alisantes, como um símbolo de orgulho e autoafirmação negra.

O cabelo retém em si uma das marcas mais distintivas e significativas da população afrodescendente no contexto diaspórico. E nas discussões em torno do combate ao racismo, o apelo à naturalidade do corpo negro trata o cabelo como uma construção ideológica e política de afirmação, demarcando um pertencimento a uma comunidade. Exibi-lo ao natural publicamente encenava, portanto, uma crítica às estruturas hegemonicas. A ideia de naturalidade aqui implica em uma percepção de uma estética ainda sim produzida, só que coerente com uma idealização do espontâneo (SANTOS, 2000), em oposição a uma artificialidade atribuída ao padrão branco-ocidentalizado de beleza e uma crítica à manipulação do corpo por ferramentas e produtos químicos a fim de se adequar a essa padronização. Os partidários dessa concepção da naturalidade acreditam que, por meio da politização da consciência racial e do próprio corpo negro, podem chamar a atenção para a importância da negritude e para as pautas do movimento. Assim, destacavam o uso de uma textura mais próxima ao natural em uma leitura ideológica da construção de uma identidade negra ideal. Essa estratégia se relacionava a uma demanda por reconhecimento de uma autoimagem construída positivamente, em sociedades que desvalorizavam a aparência negra. A naturalidade, aí, se referia mais a um atributo simbólico, pois não significava a total ausência de interferências estéticas. Estas seriam de outra ordem, que não modificariam a estrutura, mas realçavam a textura original, especialmente enfatizando a diferença em relação ao cabelo liso. Usar, assim, o cabelo "natural" era uma forma de comunicar uma intervenção nas hierarquias de cor que definiam o "bom" e o "ruim" em matéria de estética capilar, e o cabelo era convertido 
em uma espécie de mediador entre uma aparência física e um discurso da negritude.

No contexto brasileiro, o cabelo, mais do que a cor da pele, é visto como marca indelével da condição física negra. Para Nogueira (2007), existiriam dois tipos de preconceito: o de origem e o de marca. O preconceito de origem, que caracterizaria os EUA, por exemplo, tem relação com a suposição de que todo indivíduo que descende de certo grupo étnico pode sofrer as consequências do preconceito, mesmo os mestiços, independente de sua aparência ou proporção de ascendência. Assim, quaisquer "potencialidades hereditárias" permitiriam que o indivíduo se filiasse "racialmente" ao grupo discriminado e, portanto, passível de sofrer discriminação. Para Wacquant (2004, p. 162), a "guetificação" dos negros nas grandes cidades americanas acelerou essa amalgamação social e simbólica de mulatos e negros em uma "raça" única negra, e com o advento da indústria cultural, a consciência racial foi transformada em um fenômeno de massa, motivando a mobilização também de comunidades negras em outras partes do mundo. Já o racismo no Brasil se baseia no preconceito de marca. Nogueira (2007) considera que o racismo característico da sociedade brasileira se exerceria em relação à aparência, traços físicos do indivíduo, bem como gestos e sotaques. Assim, o cabelo crespo, cacheado, "duro", "pixaim" traria a marca da "raça” negra no corpo e enfatizaria a herança da africanidade, sendo, portanto, historicamente e socialmente estigmatizado. Um estigma que deveria ser apagado, alisado, controlado como forma de fugir da discriminação.

Ao se valorizar essa textura capilar "natural", era possível enfatizar e demonstrar publicamente a origem negra, demarcando uma diferença e uma afiliação racial-identitária de forma positiva, operando ainda como uma forma de desconstrução e rejeição a uma mestiçagem cujos traços branco-europeus eram valorizados em detrimento das marcas africanas e negras. As ideias de "naturalidade" - natural no sentido de não manipulado por alisamentos ou químicas - e "autenticidade" - no sentido do cabelo tido como "verdadeiro", original, sem disfarces - caminhavam juntas e legitimavam aquele tipo de cabelo como uma marca distintiva e positiva. E também valorizavam uma articulação a uma "natureza" no sentido de origem étnica, localizada em uma África ancestral e mítica. Giacomini chama essas novas formas de estilizar o 
cabelo como "penteado soul”, que assumiria uma dupla função, expressando um diálogo com a representação de um costume "ancestral", em sua articulação a um ideal de negritude e de uma África mítica - relacionada à ideia de naturalidade, natureza, liberdade -, e, ao mesmo tempo, demarcava um compromisso com a contestação de um "penteado do padrão eurocêntrico". (GIACOMINI, 2006, p. 201) A estetização do cabelo black. Quem não tinha o cabelo naturalmente crespo, podia fazer um permanente para encaracolar os fios ou poderia adquirir uma peruca. Isso também sugere que a estética black poderia ser performatizada apenas nos bailes, enquanto outros estilos de cabelo continuavam sendo usados em outros espaços.

Negros que ousavam ostentar o cabelo natural, longo, volumoso, estavam manifestando um auto-orgulho e uma politização do cabelo, que simbolizava também uma identidade jovem. A rejeição à apresentação tradicional dos cabelos de indivíduos negros, quase raspados para os homens ou alisados para as mulheres, revelava ainda uma negação ao padrão de comportamento das gerações anteriores, uma atitude jovem, cosmopolita e uma subversão às regras estabelecidas em relação ao "lugar do negro" em uma sociedade racializada. Dom Filó relembra, em depoimentos concedidos a Pedro Schprejer e Rita Ribeiro, dois momentos de sua biografia em que o cabelo se tornou um instrumento de luta e afirmação individual e coletiva:

Para falar a verdade naquela época você tinha dois cortes, ou esse que era o meu e de alguns adeptos, o black-power, e aqueles que usavam o Príncipe Danilo que era raspadinho do lado e só uma cuia na cabeça. Até dentro de casa a gente tinha uma pressão da mamãe, do papai, eles diziam: 'não vai cortar esse cabelo, tá parecendo macaco'. Então a gente já tinha no subconsciente que não podia passar de um centímetro o cabelo, ou melhor, meio centímetro. Então, isso aí fez com que alguns começassem a discutir essa questão da discriminação. (RIBEIRO, 2008, p. 164)

Nossa auto-estima era, até então, muito ruim, dentro de casa a gente se autodiscriminava. [...] Os moleques davam cascudo na gente. A gente tava cansado daquela onda. Aquilo era muito careta. [...] Foi quando surgiram os blacks. E começamos a assumir dentro de casa. Cinco anos depois, meu pai já usava black, minha mãe deixou 
de alisar o cabelo. Mudou o contexto da família negra, o visual, e a auto-estima foi lá em cima! (SCHPREJER, 2009)

A pluralidade de escolhas disponíveis na conformação do estilo estava ligada à relação com os outros, com a família, os amigos e os pares, estabelecendo um processo de "transformação da intimidade". (GIDDENS, 2002, p. 85) Além da questão política deliberada, os cuidados com o cabelo tinham uma relação direta com o surgimento de novos consumidores e mercados, da mesma forma que alternativas artesanais e criativas self-made eram uma forma de atender às novas demandas. "Nós não tínhamos produtos, nós não tínhamos nenhum pente. Então nós passamos a criar os nossos produtos. Por exemplo, eu penteava meu cabelo black com aros de bicicleta enfiados em uma madeira”, conta Dom Filó em entrevista ao programa Caminhos da Reportagem (2014). A utilização do ouriçador, um tipo de pente em formato de garfo, com dentes finos, também demarcava um novo símbolo para a afirmação do orgulho negro. Em entrevista, Oziléia Souza diz que:

O ouriçador era meu companheiro de bailes. Na rua, pessoas brancas riam do meu cabelo, mas aí que dava vontade de deixar o black mais alto. Ninguém podia encostar a mão, e nos bailes era uma disputa para ver quem tinha o black mais arredondado e arrumado.

O pente garfo, utilizado para soltar os cachos e enfatizar o volume capilar, possuía um significado importante para ativistas negros norte-americanos - e também para cantores e atletas negros -, que usavam o objeto preso aos cabelos, um costume que foi mantido pelos rappers e jogadores de basquete na atualidade. Esse hábito reportava ao papel simbólico importante em algumas sociedades africanas ao longo do tempo, em que o pente era tido como um artefato de poder, muitas vezes confeccionado como objeto artístico que representava status, afiliação a um determinado grupo social e até mesmo crenças religiosas e místicas.

Algumas iniciativas pontuais tentavam atender à necessidade dos consumidores negros, já que, por volta de 1976, a cena dos bailes black tinha se mostrado um grande mercado consumidor não apenas de discos e roupas, mas também de artigos de beleza. O americano Jim Lee, que veio para o Rio 
jogar basquete no time do Flamengo, segundo Essinger (2005, p. 35), acabou ficando na cidade e montou uma firma de importação de cremes e pentes para as cabeleiras black, revendendo também bebidas. Mas, com o declínio da moda black e o acirramento da repressão em relação aos bailes, o americano desfez o negócio e retornou para os EUA.

As diferentes formas de penteados afros, dessa forma, dialogavam tanto com uma moda afro-americana quanto com uma ideia de ancestralidade, difundido entre seus adeptos o sentimento de pertencimento a uma comunidade mais ampla: os negros da diáspora. Ao expressar o orgulho negro, o cabelo era politizado e suas diferentes formas de manipulação podiam ser compreendidas como maneiras de manifestar e afirmar uma identidade. O penteado afro natural, bem como o uso de tranças, era uma forma de construir politicamente uma aparência como parte de uma contestação estratégica de uma estrutura racista e de um padrão eurocêntrico de beleza. (MERCER, 1987, p. 40)

As afiliações a diferentes equipes também determinavam a forma como os fãs usavam seus cabelos, de acordo com gostos e referências diferentes. Uma parte dos frequentadores se identificava com uma estética mais africana e costumava usar batas e calças coloridas em estampas próximas a padrões africanos. Eram comuns também os adereços que faziam alusão a esse imaginário, em acessórios como correntes grossas, colares de contas, brincos grandes de madeira, pulseiras e turbantes ou lenços amarrados na cabeça. As tranças ainda eram novidade, e era possível encontrar alguns poucos salões que trançavam cabelos. O mais comum era o uso de “coquinhos”, vários pequenos coques em torno da cabeça, feitos em casa, bastante estigmatizados por serem associados a um tipo de penteado de "escravos", que, naquele momento, passaram a ser exibidos publicamente, amarrados com tiras coloridas.

As tranças foram bastante popularizadas pelos bailarinos do grupo Angola Soul, que acompanhava as apresentações da SGP, e influenciava os fãs da equipe. Já o visual da equipe Black Power era o topete black (ESSINGER, 2005, p. 24), com o cabelo volumoso, aparado nas laterais. A Furacão 2000 marcou a época, pois a equipe era acompanhada por uma dupla de bailarinas, as Irmãs Furacão, que, inclusive, figuraram em algumas capas dos discos da equipe. Na contracapa do LP de 1978, elas são apresentadas como duas 
excelentes dançarinas, com cabelos coloridos e dotadas de "muito swing para marcar o balanço”. As jovens fizeram sucesso com seus cabelos black descoloridos, pintados de loiro, lançando moda na época. "Quem teve a ideia de pintar o nosso cabelo foi minha mãe", conta Regilane Dutra, ${ }^{11}$ que também era filha do cantor Gerson King Combo e foi casada com Rômulo Costa, empresário que depois se tornou dono da Furacão 2000.

Nós frequentávamos os bailes da Soul Grand Prix no clube Maxwell, na Tijuca, onde morávamos. Em um baile, o pessoal da Furacão nos viu e mandou um recado para a gente, pois queriam nos conhecer, porque dançávamos bem e nosso cabelo loiro chamava a atenção. Eles nos convidaram para dançar. Acabamos nos tornando a marca da equipe.

Kobena Mercer (1987, p. 34) considera que o cabelo e as diferentes formas de manipulá-lo, moldá-lo e estilizá-lo podem ser compreendidos tanto como autoexpressões individuais como também formas de incorporação de normas sociais, convenções e expectativas do grupo. Enquanto referências culturais, o corpo e o cabelo podem ser tomados como expressões visíveis da alocação dos sujeitos nos diferentes estratos sociais. (GOMES, 2006) O cabelo, então, passa a ser compreendido como um indício marcante de procedência étnica e um dos principais elementos biotipológicos na constituição individual no interior das culturas, carregando consigo um "banco de símbolos" (SANSONE, 2004), que diz respeito a um complexo sistema de linguagem. No caso, o cabelo afro e outros tipos de penteados e adereços - como, por exemplo, tranças, dreadlocks, utilização de turbantes, flores, faixas - "assumem para o africano e os afrodescendentes a importância de "resgatar" (pela estética) memórias ancestrais, memórias próximas, familiares e cotidianas”. (LODY, 2004, p. 65) Estes seriam sinais diacríticos corporificados que rememoram a ascendência africana em um processo de identificação visual e comportamental associado a ações e reações de ativismo cultural, resistência e denúncia contra o preconceito. (GOMES, 2006)

11 Uma das Irmãs 2000, sócia da equipe Furacão 2000. Entrevista concedida à autora por telefone, Rio de Janeiro, em 27 abr. 2016. 
Diante de toda a carga simbólica depositada sobre o corpo negro, o cabelo, em si, assume um papel decisivo sobre configurações identitárias variadas, para além da aparência, ao assumir papel preponderante na construção de um estilo black. Estilo esse que passava por uma performance, uma encenação, que poderia ser acionada no momento do baile, na exibição pública de um exercício identitário. Mas, diferentemente da cor da pele, o cabelo é manipulável de acordo com a conveniência, podendo ser escondido ou ressaltado a depender do contexto. Usar o cabelo preso, alisado, em locais que exigiam maior "formalidade", como ambientes profissionais ou escolares, e ouriçado e volumoso na noite do baile demonstrava uma estratégia de acionamento de uma negritude em territórios significativos, ressaltando o deslizamento e mobilidade da identidade quando articulada à linguagem do estilo. O cabelo, enquanto marcador étnico-racial, é convenientemente convocado, mesmo que na temporalidade de uma noite de final de semana, cuja forma deliberada, autônoma e positiva o remete ao status de ato político, mesmo que de acordo com o espaço para o qual essa estética é concebida. E quando o cabelo, seu volume e sua naturalidade ultrapassavam o espaço do baile, havia efetivamente uma subversão da norma, redirecionando aqueles indivíduos excluídos a uma ação de resistência a partir da provocação e da visibilidade do que antes era reprimido, modificado, oculto.

A variedade de opções estéticas e referências culturais disponíveis naquele momento permitiam que os integrantes da cena black pudessem fazer diferentes escolhas na criação de uma identidade significativa, que poderia ser variável de acordo com os contextos e conveniências. Na configuração desses novos exercícios identitários, era possível reavaliar continuamente afiliações tradicionais e novas influências, conjugando-as de acordo com desejos de apresentação pública e impulsos individuais, estabelecendo narrativas próprias que possibilitavam novas visões e compreensões do presente e da realidade vivida. Naquele momento, as lógicas do estilo se constituíam como estratégias que ocupavam o lugar de discursos. O estilo criava um canal de representação alternativa materializada sobre a superfície cultural da vida cotidiana a partir da partilha coletiva de uma experiência da negritude. Isso reforçava laços de solidariedade entre um grupo subalterno, compensava sentimentos de exclusão e possibilitava uma inserção em um mercado 
de consumo que era uma porta de entrada para a vivência da modernidade, negociando, por meio da exibição e performatização da diferença, um poder reivindicatório.

Ao construir seu estilo por meio de improvisações e mesclas com signos provenientes de uma cultura globalizada, conjugando modas em evidência com traços que diziam respeito a uma tradicionalidade, os participantes da cena da Black Rio criavam um inventário autoexpressivo, realocando a si mesmos e suas comunidades no mundo, denunciando também suas condições de exclusão e desejo por maior mobilidade social. A ressignificação do espaço dos bailes, mediados pelas negociações com o mercado e pela oferta de uma multiplicidade estilística marginal e heterogênea era acionada por meio do prazer, da celebração, da alegria e da autoestima, e nesse ponto, a música ocupou lugar central como fator de aglutinação, mobilização e banco de símbolo de referências. No capítulo seguinte, proponho uma análise de um produto musical ligado à configuração da cena black, como forma de compreender as variadas formas de circulação do gênero da soul music que geraram transformações e impactos sociais e econômicos, provocando uma redistribuição de poderes envolvendo músicos, ouvintes e a indústria musical - que abarca instâncias fonográfica, de entretenimento e comunicativas - em um contexto no qual ingressavam novos atores no processo de mediação. 


\section{A música dos bailes}

Dentro do estilo da Black Rio, as formas de fruição da música têm um papel preponderante, e o soul assume a centralidade da cena, pois era primeiramente o consumo musical que fundamentava as mediações comunicacionais no contexto dos bailes. Na impossibilidade de presenciar um baile soul pela distância temporal entre esta pesquisa e o desencadeamento do fenômeno, proponho, como recurso metodológico, analisar um dos discos mais relevantes do período, lançado por uma das maiores equipes de som da época. Além dos altos índices de vendas, a escolha do LP da SGP de 1976 é justificada pela sua celebridade e qualidade, que contribuiu para a manutenção do seu valor e da sua importância ao longo do tempo, sendo reconhecido por fãs brasileiros de black music como um dos mais importantes da cena soul carioca. Esse disco, nos depoimentos com atores da cena, era recorrentemente mencionado como um dos mais memoráveis e, hoje, é considerado um item de colecionador bastante valorizado - é possível encontrar LPs originais por valores que variam entre $\mathrm{R} \$ 120$ e R \$200 no site de leilões on-line Mercado Livre.

$\mathrm{Na}$ tentativa de capturar a atmosfera dos bailes e o entorno midiático no qual essa cena musical se configurou, esse LP também funciona como o registro de um possível set list de um baile, e a análise de cada faixa, bem como a interpretação de elementos visuais que compõem o álbum, é conjugada a 
informações disponíveis nas fontes consultadas sobre os bailes, sobre o mercado musical e sobre a atuação dos DJs de soul. No mercado das coletâneas de soul da época, esse também foi um disco especial, cujo lançamento recebeu grande investimento de marketing por parte da gravadora, a WEA, o que representava os esforços de estabelecer um segmento de mercado expressivo para o soul no Brasil, de forma semelhante ao desenvolvimento e consolidação do gênero na indústria musical dos EUA. Assim, tentarei também construir um panorama geral também sobre a configuração do soul enquanto gênero musical e suas implicações para os processos de identificação das populações negras, tanto nos EUA quanto no Brasil. E no processo de escuta e interpretação desse álbum, por fim, buscarei identificar estratégias de produção de sentido e de circulação midiática, inferindo sobre as mediações e afetos que vinculam esse disco à cena musical, utilizando tanto perspectivas de inspiração musicológica quanto semiótica, articuladas a abordagens sociológicas e históricas, "[...] de modo a oferecer respostas mais complexas sobre as relações de sentido e de sensibilidade que emergem na escuta dos distintos gêneros musicais”. (CARDOSO FILHO, 2014, p. 7) A interpretação da trajetória dessas produções musicais em suas especificidades pode nos oferecer uma chave interpretativa das diferentes maneiras pelas quais a música se materializava nas pistas dos bailes e das cenas musicais, convocando os frequentadores à dança e à celebração por meio da corporificação de diferentes performances e gestos, que também são parâmetros fundamentais do estilo.

\section{Um álbum de equipe}

Uma das maiores equipes de som da cena Black Soul, a SGP desencadeou um novo momento para a cultura black na cidade, realizando bailes em vários bairros da Zona Norte à Zona Sul. Lançando vários discos até os anos 1990, a SGP foi responsável pela introdução na cena Black Soul de novas sonoridades associadas ao soul e ao funk norte-americanos. Foi selecionado o LP da equipe lançado no ano de 1976, auge do movimento Black Rio, quando o empreendimento se transformou em um complexo empresarial de entretenimento altamente lucrativo. Após um disco de relativo sucesso lançado pela Top Tape em 1974, a equipe foi convidada pelo executivo e diretor da Warner 
do Brasil, André Midani, para encabeçar o segmento soul da companhia. A estratégia foi bem-sucedida e o LP da equipe lançado pela WEA recebeu o disco de ouro: "[...] Era uma coletânea de música soul e vendemos mais de 106 mil cópias em poucas semanas. Chegamos à frente do Roberto Carlos". (DOM FILÓ, 2009)

Definitivamente, as coletâneas foram o formato discográfico mais consumido pelo público dos bailes black, e várias outras equipes e DJs também lançaram discos de sucesso. Esse modelo baseado em compilações musicais era composto por gravações de soul e funk previamente selecionadas pelos DJs das equipes e integravam os set lists dos bailes, mostrando-se de antemão bem-sucedidas nas pistas de dança, aprovadas pelos frequentadores, o que diminuía os riscos de não aceitação. Mas, aos poucos, as coletâneas basicamente se tornaram uma estratégia para as gravadoras colocarem em circulação músicas de seus catálogos, divulgando hits de artistas famosos e lançando novos cantores - muitas vezes, as coletâneas de soul eram lançadas antes ou paralelamente aos discos de carreira dos artistas. Para o público, esse formato também era mais econômico, pois, para ter em casa os grandes sucessos dos bailes, não seria necessário comprar um disco de cada artista, e a coletânea também possibilitava o contato e o consumo de diversos estilos e subgêneros contidos em apenas um produto.

Até o final dos anos 1960, os consumidores brasileiros compravam, em geral, mais compactos simples, cujo formato menor barateava o preço. Isso motivava o sucesso de uma determinada canção específica, e não da obra inteira. O maior investimento em coletâneas representava um segundo momento, que refletia um direcionamento mais incisivo da produção fonográfica para o público jovem e de menor poder aquisitivo. Além disso, as produções internacionais eram muito mais rentáveis para as gravadoras, reduzindo gastos em relação ao investimento em artistas locais, já que era mais barato lançar um disco estrangeiro. Assim, evitavam-se despesas com estúdios, músicos de acompanhamento e arranjadores, e o custo maior se referia apenas ao pagamento de royalties para a matriz importada. Não foi à toa que, em 1977, oito meses após sua instalação no Brasil, a WEA já havia realizado 167 lançamentos estrangeiros no país. 
Havia também uma outra diferença fundamental na circulação mercadológica do formato das compilações internacionais. A venda de coletâneas fazia com que os gêneros musicais ganhassem mais importância do que os artistas. Assim, as canções mais famosas, os hits de determinado gênero, recebiam mais destaque do que o artista propriamente. Tanto que, até hoje, os discos de soul ou determinadas canções são decididamente mais lembradas pelos fãs do que nomes de cantores ou bandas menos famosos, ou do que seus álbuns originais. Muitos discos de carreira, de fato, nem eram lançados no Brasil, apenas alguns fonogramas com as músicas de trabalho, que integravam as coletâneas. Tárik de Souza (1976, p. 10) chamava esses lançamentos de "discos de retalho", que continham "mais sucessos por menos centímetros de matéria-prima”. Dessa forma, uma determinada coletânea poderia alcançar uma grande vendagem, enquanto o artista ou banda poderia não lograr da mesma repercussão em seus trabalhos autorais. Isso também aumentava a rentabilidade das coletâneas, que eram produtos mais baratos do que um disco de carreira porque prescindiam de grandes gastos com divulgação e trabalho da imagem de algum artista específico.

Nessa época, alguns discotecários já produziam e mixavam suas próprias coletâneas, como Ademir Lemos e Big Boy, ora colando faixas umas nas outras, sem pausas - no formato non-stop -, ora editando e inserindo efeitos sonoros, vinhetas e vozes, para dar efeito de um set de baile. Era possível também aumentar o tempo de duração das músicas, e muitas coletâneas eram compostas por versões exclusivas de canções norte-americanas, que se tornaram raridades, em muitos casos registrando gravações produzidas especialmente para integrarem as coletâneas brasileiras. O estilo de música que predominava nas coletâneas era o soul-funk; entretanto, em fins dos anos 1970, compilações foram lançadas contendo já alguns sucessos da disco music, refletindo também a opção de algumas equipes que passavam a investir nesse segmento.

As gravadoras trabalhavam a imagem das equipes de som como se elas fossem um "artista" propriamente e ganhavam um status privilegiado não por serem autoras de canções de sucesso, mas por serem “autoras” da seleção dos melhores hits, que davam aos seus bailes um diferencial. Especialmente a Warner, na figura de André Midani, investia fortemente na divulgação dos discos da SGP, organizando grandes festas de lançamento, promoções, 
e comprando bastante espaço publicitário na TV, rádio e jornais. O nome da equipe, que suplantava o nome dos donos ou DJs integrantes, servia como garantia de qualidade e dava aos sucessivos lançamentos de coletâneas assinadas por ela uma regularidade musical, garantindo a consolidação da carreira da equipe enquanto lançadora de sucessos não apenas nas pistas de dança, mas também diretamente no mercado do disco nacional. O primeiro disco da SGP também foi trabalhado como um álbum, mas, diferentemente do que se propunha esse formato discográfico, partiu de uma criação coletiva, que somava o faro da equipe para a escolha de hits com a imposição da gravadora para a divulgação de seu catálogo, levando também em consideração constrições do mercado, valores e gostos da audiência.

A escolha pelo formato LP também representava uma maior lucratividade. Os discos do vinil com 12 polegadas eram inicialmente apenas consumidos por disc-jóqueis, enquanto o público geralmente adquiria compactos ou compactos duplos, de preço menor. A capacidade maior de armazenamento, com cerca de 20 minutos em cada lado, mudou a forma de escutar música e diminuía o custo de produção. Além disso, foi possível se pensar em um conjunto de canções com certa unicidade que passaram a compor os discos, vistos como uma obra musical com unidade estética que "redimensiona o álbum para uma perspectiva em que seu consumo abrange outras esferas sensoriais além da predominantemente auditiva”. (FREITAS, 2013, p. 45) Os álbuns passaram a exigir uma produção mais apurada, a fim de tornar o produto mais atraente, e as gravadoras começaram a investir em projetos gráficos mais elaborados para capas e encartes, que tornavam o disco, em sua materialidade, também uma extensão da imagem e da trajetória midiática do artista, agora visto como um criador de uma obra de arte. Ao assinar suas próprias coletâneas, as equipes, pois, assumiam para si o status de autoras, não referente a uma autoria individual, mas sim a um "autor coletivo". E, de fato, na contracapa do álbum, quem assina a coordenação artística da obra é a própria SGP. Sobre o processo de negociação e lançamento de coletâneas assinadas pela SGP, Nirto e Filó comentam:

O processo de lançamento (de uma música) é realizado em convênio com a gravadora, que traz a matriz, e a equipe, que lança no 
baile. A seleção para o baile é feita na base da qualidade, e a grande preocupação é não viciar o público em termos de comércio. O primeiro contato que fizemos para edição de disco pela Top Tape foi na base de Cr\$1,00 por disco. Agora, a WEA, por intermédio do Sergio Motta e do Mazzola (diretor de catálogo internacional e vice-presidente artístico, respectivamente), entrou em entendimento conosco, nos oferecendo um catálogo da King e da Atlantic para nós selecionarmos um LP. (BAHIANA, 2006, p. 305)

A WEA comprou a Atlantic Records (Atlantic Recording Corporation) em 1967, mas o selo independente havia sido criado 20 anos antes pelos irmãos Ahmet e Nesuhi Ertegün e por Herb Abramson em 1947. Com foco principal em jazz e R\&B, voltada para um público majoritariamente negro, a Atlantic foi responsável pelo lançamento, nos anos 1950, de grandes nomes como Charles Mingus e John Coltrane, integrantes de sua divisão jazzística, e revelou, na mesma época, o mega-astro Ray Charles, o grande percursor da soul music. Segundo Márcio Ribeiro (2003), foi a Atlantic, inclusive, que cunhou o termo "rhythm \& blues" para identificar a música feita por artistas negros, cujos discos até então eram chamados de race records. Os discos da Atlantic possuíam uma produção apurada, e a gravadora recorria aos melhores estúdios do país para a gravação de seus discos - incluindo os estúdios da Stax -, o que a tornou um dos empreendimentos mais bem-sucedidos dos EUA. Também integravam o seu cast Aretha Franklin, Wilson Pickett, Sam \& Dave, Otis Redding e Roberta Flack. A gravadora, posteriormente, passou a diversificar seu elenco, investindo no rock-pop ao lançar grupos como o Vanilla Fudge, Iron Butterfly, Yes e o seu maior sucesso comercial, o Led Zeppelin.

\section{A emergência do soul}

O termo "soul music", em seus primórdios, se referia a um conjunto de sonoridades e musicalidades que utilizavam figuras melódicas e riffs derivados da música gospel e do folk blues, que englobavam a música popular negra no começo dos anos 1960, de acordo com Brackett (2009). O soul era proveniente também do jazz e do R\&B - que se originou da eletrificação do blues, 
com ritmo mais acelerado e instrumentos como guitarra e baixo elétricos-, o que demonstra a interconexão entre diferentes gêneros que compartilhavam abordagens harmônicas, tipos de ritmos, melodias e timbragens semelhantes.

Mas os gêneros realmente se diferenciam, seja pela forma e o grau em que esses elementos são colocados em jogo, seja pelo tema das letras. Assim, a emergência da música soul a partir do rhythm and blues no início dos anos sessenta é mais uma mudança de ênfase do que uma importação de novos elementos da música gospel (como se diz às vezes). Todavia, o crescente emprego de técnicas vocais para significar êxtase espiritual, intensidade e devoção num contexto secular intensificou tanto o senso tanto de identificação apaixonada do cantor com a canção quanto de conexão entre o estilo de música e a comunidade negra. (BRACKETT, 2009, p. 63)

Assim, o soul, como integrante de uma cultura afro-americana de entretenimento, se desenvolveu nos EUA entre 1890 e 1930, a partir da circulação em maior escala do jazz e do blues especialmente em cidades como Nova Orleans, Chicago, Memphis e Nova York - especificamente no bairro do Harlem -, que atraíam tanto uma audiência emergente negra urbana quanto um público branco. (OSTENDORF, 2000) A relação entre o soul e a comunidade afro-americana era um fato concreto, e o desenvolvimento do gênero acompanhou a evolução do movimento pelos direitos civis, dando voz às movimentações culturais e políticas do período, incentivando a conscientização política e racial da população negra norte-americana e chegando também a outros contextos sociais em diferentes países. Além disso, a música acompanhava ainda a própria ascensão social e econômica do negro americano. (SOUZA, 1976, p. 10)

Para alguns pesquisadores, o soul, nos seus primórdios, não se referia essencialmente a um ritmo ou gênero musical determinado, mas dizia respeito a uma forma singular de interpretar canções, cuja terminologia serviria para designar vários aspectos de um ethos afro-americano. (CAVALCANTI, 1981, p. 6) Assim, o soul fazia referência a elementos culturais afro-americanos, como à soul food, culinária específica das comunidades negras do sul dos EUA. E soul music nada mais era que as músicas produzidas pelos negros, 
englobando vários gêneros, e não havia propriamente canções, mas sim intérpretes soul que traduziam o sentimento de uma "alma negra" na forma de cantar com emoção e habilidades vocais peculiares. Mas, aos poucos, o soul começou a se delinear como gênero, ganhando contornos específicos, e "[...] nos anos 70, o termo se generalizou de tal forma, cobrindo estilos tão variados, de Roberta Flack ao Jackson Five, que a única unidade identificável, nesse terreno, está no fato de todos os artistas soul serem negros”. (RISÉRIO, 1981, p. 29)

Dentre as características do canto soul, estava a utilização de melismas sofisticados, progressões harmônicas derivadas do gospel, mas com uma orientação mais pop, presente tanto na recorrência de temáticas amorosas como na adoção eventual de estruturas rítmicas próprias para a prática da dança - em pares ou solo. Ray Charles, um dos primeiros cantores de soul, ganhou fama ao reunir em suas composições elementos do R\&B e do gospel. Reproduzindo inovações já empregadas por alguns cantores menos famosos, como a utilização de padrões de chamada e resposta entre sua voz e conjuntos de metais, ou então alternando com o canto em coro de backing vocals, Ray se inspirava no formato de canções religiosas para compor músicas que falavam sobre temáticas seculares - muitas vezes, substituindo expressões como "Lord" por "baby" -, inserindo técnicas vocais como gritos, interjeições e melismas. (BRACKETT, 2009, p. 63) Sua canção de 1958, "I got a woman”, é considerada por muitos como o marco do nascimento do soul. Recursos semelhantes também foram utilizados por James Brown, cujo canto áspero, exuberante e aberto era semelhante à forma como pastores negros pregavam em seus cultos, exortando os fiéis. Logo, outros cantores que também se identificavam com o soul passaram a empregar outros estilos de canto, mais suaves e sofisticados, como Sam Cooke - que saiu das hit parades negras para alcançar as paradas de pop music, rótulo adotado primeiramente para definir as produções musicais voltadas para o público branco -, em baladas românticas que não apelavam tanto para temáticas sexuais nas letras ou vocalizações.

No começo dos anos 1960, a música soul começava a se distanciar das bases musicais do $\mathrm{R} \& \mathrm{~B}$, começando a assumir características diversificadas e identificáveis a partir da ação de músicos ligados às várias gravadoras 
independentes localizadas em diferentes regiões dos EUA. Apesar de diferenças regionais imprimidas por cada selo nas canções, esses artistas possuíam uma certa coesão, como aponta Brackett (2009, p. 64): "Além dos melismas, bends e amplo espectro de timbres empregados pelos lead vocalists, estas canções, todas em tempo lento, davam destaque a subdivisões em quiálteras, frequentemente articuladas em arpejos de piano ou violão".

Nos centros urbanos de Nova York, Filadélfia e Chicago, o tipo de soul produzido concentrava-se em gravações nas quais o vocal ganhava mais destaque do que o acompanhamento instrumental, em melodias mais suaves, um tipo de sonoridade particularmente trabalhada pela Atlantic. O soul da cidade de Detroit era representado pela Motown, cujo cast possuía nomes de peso do quilate de Marvin Gaye, The Temptations, Smokey Robinson, The Supremes e The Four Tops. As gravações da Motown tinham uma orientação mais pop e mais dançante, com arranjos que utilizavam uma linha de baixo mais forte - incentivando a prática da dança -, vozes suavizadas em modulações sofisticadas e canções de temática romântica, frequentemente incluindo acompanhamentos de palmas e pandeiros, elementos apropriados também da música gospel, que exerciam grande apelo sobre a juventude branca norte-americana.

No sul dos EUA, o soul assumia uma sonoridade mais tradicional, pesada e marcada, com ritmo mais sincopado, vocais crus e inflamados, inspirados nos estilos de canto do blues, e "cozinhas" de metais mais completas, que ocupavam o lugar dos backing vocals, representado pela produção da gravadora Stax, baseada em Memphis, Tennessee. A Stax, deliberadamente, cultivava um soul bem característico, que incluía a colocação dos vocais mais atrás durante a mixagem da gravação em comparação a outros discos de soul da época, privilegiando o trabalho instrumental de conjuntos como Booker T and the MGs e The Bar-Keys. O selo contava ainda com Otis Redding, Carla Thomas, Sam \& Dave, Rufus Thomas e Isaac Hayes - e basicamente seu casting compunha o set list dos bailes e coletâneas lançados por Mr. Funky Santos.

Entre os anos de 1964 e 1966, as técnicas de gospel empregadas pelos lead vocalists continuaram, enquanto os instrumentos acompanhantes adquiriram maior definição através do uso de riffs rítmicos. 
O baixo, em particular, ganhou proeminência através do emprego crescente de padrões sincopados e os metais começaram a ser usados em rajadas sincopadas em staccato. (BRACKETT, 2009, p. 64, grifo do autor)

No início dos anos 1970, influenciados pelo rock psicodélico, cantores como Marvin Gaye (What's going on, Motown, 1971) e Curtis Mayfield (Superfly, Curtom Records, 1972) lançaram os primeiros discos conceituais de soul, cujas temáticas das canções eram baseadas em críticas sociais. O ritmo das faixas possuía subdivisões mais regulares em arranjos mais elaborados utilizando orquestras ou conjuntos de cordas. A questão da temática político-racial já vinha sendo explorada com bastante sucesso em hits de Aretha Franklin, com "Respect" (1967), e "Say it loud - I'm black and I'm proud" (1968), de James Brown, que assinalaram o começo de uma fase mais politizada da música soul.

Nesse momento, o soul já havia se transformado em um termo vago, sinônimo de black music, em processo de absorção por um mercado mainstream, bem assimilado pelas plateias brancas. Artistas influenciados pelo soul agressivo e dançante de James Brown, em uma tentativa de diferenciar-se do soul-pop, passaram a desenvolver uma sonoridade mais radical, com ritmos mais fortes e marcados e arranjos mais "pesados" e complexos, incluindo a utilização de percussão e metais, cujas frases musicais reiterativas permitiam maiores improvisos instrumentais, em uma ligação mais direta com o jazz e o próprio rock. Especialmente Brown estimulou o desenvolvimento de uma estética funk ao introduzir uma percussão pesada e quebras no ritmo (break beats), inserindo nas canções também sons pouco convencionais como gritos, sussurros, distorções na voz (SILVA, 2011), alternando entre falsetes e gritos mais graves, alternados com riffs exuberantes de baixo, guitarra e solos de bateria. As músicas ganharam um andamento mais rápido, com linhas de baixo mais ativas, e tanto a guitarra quanto bateria ganhavam destaque em solos arrojados.

Foi nessa época que a gíria "funky" deixou de ter o significado de algo ofensivo, pejorativo, e passou a designar modos de comportamentos tidos como característicos e positivos dos negros norte-americanos, como gestos, 
roupas, gírias: “[...] tudo podia ser funky: uma roupa, um bairro da cidade, o jeito de andar e uma forma de tocar música." (VIANNA, 1988, p. 20) "Funk" passou a designar as novas produções da black music e passou a ser mais ostensivamente utilizado nos EUA na virada da década de 1960 para 1970. "Na realidade, com a intensa presença do soul no mercado, alguns músicos mais engajados da época passaram a encarar o funk como uma vertente da música negra ainda capaz de produzir uma música, digamos, 'revolucionária”. (HERSCHMANN, 2000, p. 21) Dentre os representantes do funk, destacava-se o guitarrista George Clinton, que, com suas bandas Parliament e, posteriormente, Funkadelic, desenvolveu um tipo de funk mais pesado, influenciado pela psicodelia. Outros grupos de funk que surgiram no período, incluindo Earth Wind \& Fire, Sly and The Family Stone, KC \& Sunshine Band, Kool \& The Gang, Chic, The Gap Band e músicos/cantores como Jimmy “Bo” Horne e Chaka Khan - muitos deles gravaram grandes sucessos da disco music. Os primeiros trabalhos dos Jackson Five também fazem parte dessa categoria.

Outra vertente do soul, de estilo mais suave, inspirado na Motown e nas baladas românticas de cantores como Curtis Mayfield, foi o chamado Philly soul, originário do estado da Filadélfia. Representado por bandas como Harold Melvin \& The Blue Notes, The O'Jays e The Stylistics e pelo músico Billy Paul, o soul da Filadélfia era profundamente marcado por arranjos de cordas e metais em gravações mais dançantes, mas ligeiramente mais lentas, em que as vozes eram registradas com mais "limpeza" e nitidez, com um apelo mais pop. Essa sonoridade foi desenvolvida nas gravações lançadas pelo selo Philadelphia International Records, fundada em 1971, que eram marcadas por arranjos orquestrais, linhas de baixo bastante marcadas e percussão vigorosa em canções animadas e vibrantes. "O som característico de bateria enfatizava os médios e frequentemente acentuava cada batida”, como considera Brackett (2009, p. 66), influenciando a disco music na década de 1970 ao apresentar canções mais "melosas" e mais "bem comportadas" em relação a outros estilos de soul e funk. Ao lado das seções de sopro e cordas dos arranjos, que concediam certo refinamento e sofisticação, eram contrapostos teclados e sintetizadores, que davam um tom mais moderno às composições, apesar de serem mantidas as estruturas musicais tradicionais. Os produtores Kenneth "Kenny" Gamble e Leon Huff criaram a marca do Philly soul dentro 
da gravadora, compondo e produzindo canções precursoras do estilo, como "I love music" (1975), dos The O'Jays, "The love I lost" (1973), de Harold Melvin \& the Blue Notes, e "The Sound of Philadelphia (TSOP)" (1973), do conjunto Mother, Father, Sister, Brother (MFSB), trilha sonora do programa norte-americano Soul Train.

A SGP, representada pela figura do DJ Luizinho - ou melhor, Luizinho Disc-Jockey Soul -, foi responsável pela introdução do Philly soul na cena dos bailes black cariocas. Luiz Stelzer era um jovem branco apaixonado por soul. Começou sua carreira discotecando em boates da Zona Sul e sua fama cresceu. Luizinho garimpava novidades dançantes entre os discos promocionais dispensados pelos DJs de outras casas, o que garantia originalidade a seu trabalho. Logo recebeu um convite dos donos da SGP, que foram até a discoteca onde o jovem DJ tocava. Luizinho recusou o convite, mas a SGP não desistiu e ofereceu como pagamento adiantado um fusca. Diante da proposta irrecusável, o DJ finalmente aceitou ingressar na equipe como disc-jóquei principal, na qual permaneceu alguns anos até fundar sua própria equipe, a Power Som, atuando também com produção de rádio, lançando algumas coletâneas de sucesso e montando um equipamento de alta qualidade que alugava para outros eventos, como a sonorização do Carnaval na Avenida Rio Branco, Centro do Rio.

\section{Uma black em uma moto}

A capa tinha uma black em cima duma moto - um negócio revolucionário na época. Dom Filó ${ }^{12}$

O primeiro LP da SGP também marcava a entrada da Atlantic no mercado brasileiro, e seu catálogo de artistas serviu como fonte para a compilação das faixas que compuseram o disco da equipe. A WEA, detentora dos direitos e distribuidora da Atlantic no Brasil, investiu na qualidade do álbum, cuja capa dupla foi ilustrada pela dupla de artistas plásticos Walney de Almeida

12 Em entrevista a Edson Lopes Cardoso em 2009. 
e Miranda de Almeida, que também atuavam em publicidade. Walney, especialmente, também integrava o departamento cultural do Clube Renascença e era amigo de Nirto e Dom Filó, participando ativamente das atividades do clube, como a produção da peça Orfeu da Conceição e de rodas de samba, bem como da cena da Black Rio. O design gráfico ousado da capa tinha inspiração na arte psicodélica, abusando das cores fortes e formas abstratas, bem como de desenhos surrealistas de inspiração onírica, em um traço próximo à Pop Art. Esse tipo de ilustração, baseada na superposição de imagens e cores contrastantes e saturadas, com efeito caleidoscópico ou "lisérgico" era bastante usado também em capas de disco de rock da época e tinha relação com os movimentos contraculturais jovens dos anos 1960 e 1970. Um exemplo foram as capas de discos célebres como Sgt. Pepper's Lonely Hearts Club Band, de 1967 - criada por Peter Blake, um dos fundadores da Pop Art -, e Yellow Submarine, de 1969 - do artista tcheco Heinz Edelmann. Grupos de funk e soul também adotaram o visual psicodélico nas capas de seus LPs, como Kool \& The Gang (Spirit of the Boogie, 1975) e The Dramatics (Whatcha See Is Whatcha Get, 1971). No Brasil, as capas dos álbuns Jorge Ben, de 1969, criada pelo artista plástico Albery, Jardim Elétrico (1971), dos Mutantes, e o primeiro disco de Caetano Veloso, de 1969, seguiam essa tendência.

A capa do disco da SGP também fazia eco às capas de discos de soul norte-americanos, em que personagens negros ganhavam destaque principal na narrativa visual. A célebre capa do disco de compilação de canções de sucesso de Marvin Gaye, Super Hits (1970), mostrava um super-herói negro salvando uma mocinha também negra, com cabelo afro, ao estilo das HQs. Havia uma demanda clara por parte do público negro em adquirir produtos nos quais eles se vissem e se sentissem diretamente representados, assumindo posições protagonistas, tanto nos EUA quanto no Brasil. Um jovem negro universitário confessou para Lena Frias (1976, p. 4): “[...] mas o que sei é que tem gente nas bocadas que nem compra mais discos de soul se, na capa, aparece branco". Esse consumo afirmativo era tão decisivo que, temeroso por ter seu disco rejeitado, o DJ Luizinho (ou Luizinho Disc-Jockey Soul), ao lançar seu disco O som dos blacks (1977, RCA), pintou metade do rosto de preto, em um "meio" blackface que tentava demonstrar sua afiliação não apenas ao movimento black, mas a uma identidade negra globalizada - também representada 
no uso de uma cartola com as cores da bandeira americana-, acionando ainda o valor da mestiçagem que garantiria a partilha dessa negritude.

A capa do álbum da SGP tinha também um certo tom futurista, presente nos traços da ilustração que lembrava cenas de viagens espaciais e imagens sobrenaturais, à semelhança da capa do álbum Mothership Connection (1975), do grupo de funk Parliament, ilustrado com uma foto-montagem protagonizada pelo personagem de um cafetão negro - segundo palavras do líder do grupo, George Clinton -, com roupas prateadas e botas de plataforma em uma nave interestelar sobrevoando o espaço. Fã da série de ficção científica Star Trek, em entrevista ao site Soul Train, Clinton explicou o que motivou a criação da capa: "Nós colocamos pessoas negras em situações em que ninguém jamais pensou que elas poderiam estar, como na Casa Branca. Eu imaginei outro lugar que nunca se imaginou que um negro poderia estar, que foi o espaço sideral”. (CLINTON, 2015) Outras capas de LPs de artistas de soul e funk norte-americanos da época eram também inspiradas nessa estética afrofuturista como Super Hits (1970), de Marvin Gaye, e Spirit of the Boogie, do Kool \& The Gang (1975).

A capa do LP da SGP também pretendia apresentar uma nova representação da negritude, baseada em uma estética afrofuturista, desestabilizando concepções fixas de identidade negra, baseadas em visões tradicionais ou folclóricas, pela articulação com signos da contemporaneidade, como a ficção científica e a exploração espacial com cosmologias africanas. O afrofuturismo se refere a um conjunto de manifestações culturais, compostas pela criação de narrativas fictícias ligadas a um futuro imaginário, em que negros são representados em um universo de referências ligadas à alta tecnologia e à ficção científica - em oposição à localização cultural dos povos africanos e descendentes em um passado primitivo. Criado na década de 1960, o afrofuturismo ajudou a transformar alguns paradigmas de representação e também apresentava uma crítica aos estereótipos e à representatividade negra nos produtos midiáticos, na arte, na moda e na literatura.

Seguindo essa tendência, a ilustração da mulher negra pilotando uma moto voadora representava a apropriação de uma iconografia cinematográfica da ficção científica como a ópera espacial 2001: uma odisseia no espaço (1968), dirigido por Stanley Kubrick; Barbarella (1968), dirigido por Roger 
Vadim; ou a franquia Star Wars (1977), dirigida por George Lucas. Para além de uma simbologia mágica e supernatural, a ilustração também acionava signos de transcendência, liberdade, êxodo e paz, representados por imagens como borboletas - um símbolo usual do movimento hippie -, estrelas, flores e a pomba branca voando ao lado da logo com o nome da equipe, cuja fonte das letras também apresenta um design futurista. A ideia de transformação estava presente também na grande bolha estourada, de onde sai a mulher na moto. E sua indumentária ainda trazia elementos do estilo black, como botas de plataforma (botas aladas), roupas coloridas com mangas boca de sino em estampas psicodélicas, numa imagem que conectava o disco a um conjunto de símbolos modernos e globalizados. Essas sensações e referências representadas na capa poderiam ser acionadas a partir da audição do álbum e, por conseguinte, pela ida aos bailes da equipe. Esse convite estava representado na presença de uma grande foto, de autoria de José Moura, de um dos bailes da SGP impressa na contracapa do álbum.

\section{O LP faixa a faixa}

Com 11 faixas, cinco do lado A e seis do lado B, a primeira canção do disco, ${ }^{13}$ "It's all right now", era um hit do cantor Eddie Harris, que começou sua carreira como saxofonista de jazz, e seu primeiro álbum, Exodus to Jazz (1961), alcançou as paradas de sucesso. Nos anos 1960, foi contratado pela Atlantic Records, em que começou a gravar canções que promoviam uma mescla entre o jazz e o funk, em trabalhos mais comerciais, ampliando seu público. Suas experimentações musicais, introduzindo novos instrumentos, chamaram a atenção da crítica, e Harris passou a inovar, influenciado também pelo blues e pelo rock. Essas mesclas transformaram o músico em um referencial para as futuras gerações de músicos do fusion jazz e da house music.

A faixa "It's all right now", que integra o disco That is why you're overweight, de 1975, é um "funk semi-instrumental”, swingado, em que os vocais são desempenhados por um coro que repete o único verso da canção ao longo de

13 O LP na íntegra está disponível para audição na plataforma de compartilhamento de vídeos Youtube no link: <https://www.youtube.com/watch?v=V6F4sxQAR7s>. 
3 minutos e 53 segundos, intermediado por algumas frases e interjeições entoadas pelo cantor, entremeadas por solos de saxofone e palmas, quando a canção vai chegando ao final. De andamento mais lento, é uma gravação apropriada para o começo dos bailes, criando uma ambiência para hits mais agitados.

A próxima faixa, "Love your life”, também tinha um andamento mais lento, mostrando uma intercessão entre o soul e a disco. A canção era do grupo escocês Average White Band - que possuía apenas dois músicos negros -, que, no ano de 1975, vendeu mais de um milhão de discos, liderando as paradas de sucesso norte-americanas até o final da década e atingindo tanto plateias brancas quanto negras. A canção selecionada para integrar a coletânea da SGP integrou o álbum Soul searching (1976), que ficou em segundo lugar nos charts de soul da Billboard Magazine e ganhou disco de ouro. "Love your life" fala sobre autoestima e amor próprio, utilizando ritmo mais dançante em uma batida contundente que aproxima a canção da disco music. Gênero também presente na coletânea pela inclusão do hit "Treat me like a woman" (1976), da cantora Jackie Carter, canção título do seu LP de estreia. Carter era uma cantora de estúdio e fazia parte do grupo alemão Silver Convention, um dos grandes nomes da euro disco. "Treat me like a woman" foi composta por Frank Diez, um dos mais talentosos guitarristas alemães do período, que também trabalhou com Donna Summer e contou como arranjos orquestrais do músico erudito alemão Peter Herbolzheimer. Arranjos orquestrais compunham uma das características principais da disco music, com a utilização de instrumentos de cordas (em particular, o violino), pianos e metais, uma influência notória das gravações da Motown. Já as linhas do baixo elétrico são herdeiras do funk, e há uma ênfase no canto em falsete, o que propiciou o surgimento de novos timbres de cantores com vozes mais suaves. Especialmente "Treat me like a woman" possui uma base dançante, com arranjos orquestrais bastante semelhantes ao trabalho de Isaac Hayes na canção tema do filme Shaft, que surgem em um crescente, combinadas a uma maior ênfase no baixo e na bateria, o que dá à canção um efeito dançante e luxuriante, estimulando especialmente o movimento dos quadris. Jackie Carter também utilizou o recurso de pronunciar algumas interjeições, murmúrios e gemidos, entremeando os versos da canção, que dá uma atmosfera sensual e relembra a 
estética "orgásmica" de "Love to love you baby", sucesso de Donna Summer lançado em 1975, cheia de sussurros e gemidos.

A quarta faixa é um medley do grupo vocal americano de soul Archie Bell \& The Drells, gravado exclusivamente para o LP da SGP com duas canções: "I can't stop dancing" e "Tighten'up", regravações de dois sucessos do grupo dos anos 1960, consideradas canções precursoras do funk. O grupo também aderiu ao Philly soul, gravando canções mais suaves, em oposição ao deep soul (ou southern soul), estilo de soul mais energético e agitado que marcou o início da carreira e tinha relação com a origem do grupo, criado em Houston, no Texas, sul dos EUA. A última canção do lado A do LP é “I don't want to lose you”, do conjunto Jimmy Castor Bunch. A banda liderada pelo saxofonista americano Jimmy Castor transitava entre o doo-wop, passando pelo soul, funk e também música latina. O músico foi pioneiro ao introduzir no R\&B camadas percussivas, utilizando também muitas guitarras distorcidas em seus arranjos. Seu disco Troglodyte (Cave man), de 1972, precedeu a explosão do funk na metade da década, e a faixa-título continha um discurso bem-humorado que foi sampleado diversas vezes e inspirou a primeira geração do rap americano nos anos 1980.

As baladas românticas soul também tinham espaço nos bailes, geralmente sendo tocadas após uma sequência mais agitada, a fim de que os casais pudessem dançar juntos ao som de uma música mais lenta - uma oportunidade para “o encontro dos sexos, o início de namoros, o flerte mais 'oficializado". (VIANNA, 1987, p. 100) Ras Adauto, em entrevista à autora em 21 de fevereiro de 2016, relembra: "aquela era ainda a época de namorar certinho, a gente ia para o baile para paquerar mesmo. Depois levava a menina em casa, namorava no portão. Muita gente casou depois de se conhecer nos bailes". Isso, de certa forma, contradiz uma ideia de que a cena Black Rio era uma adaptação da contracultura à vida suburbana, que mantinha ainda parâmetros de sexualidade e padrões de relacionamento tradicionais, não incorporando fortemente novas tendências comportamentais da revolução sexual, em que homens e mulheres ainda desempenhavam papéis bastante definidos de gênero e sociabilidade. Alguns momentos possibilitavam uma oportunidade de subverter regras, como nos bailes chamados de Noites da Maria Cebola, por exemplo. Nesse formato de baile, bastante popular nos anos 1970 em várias partes do Brasil, 
as mulheres tiravam os homens para dançar no momento da música lenta. A moda também chegou aos bailes de soul, como conta Oziléia Souza, em entrevista à autora em 26 de abril de 2016: "era tudo muito respeitoso, e eu só saía com meu irmão, mas nas noites da Maria Cebola era uma oportunidade para conhecer rapazes. As meninas na época eram mais recatadas, e oflerte ficava difícil, só as mais avançadinhas que tinham coragem".

O lado B do vinil é encabeçado pela instrumental “Ju Ju Man”, única música "brasileira" do álbum. Era uma regravação de uma música do grupo alemão Passport, conjunto de jazz fusion liderado pelo saxofonista e pianista Klaus Doldinger, criado em 1971, que também fazia parte do elenco da Atlantic. A canção - cuja grafia original era "Ju-Ju-Man” - foi lançada no disco do grupo, também de 1976, Infinity machine. Para o LP da SGP, a canção de mais de dez minutos foi reduzida para três minutos e ganhou um "tempero" brasileiro com a introdução de apitos e ataques percussivos em instrumentos como atabaques, congas e timbales, reproduzindo alguns toques típicos do samba, em diálogo com a bateria. O saxofonista Oberdan Magalhães foi convocado para montar um grupo especialmente para essa gravação - a Hot Stuff Band -, que teve como base o conjunto Azymuth - também contratado da WEA -, formado por músicos de estúdio experientes que tocavam com grandes nomes da MPB. Assim, a regravação de "Ju Ju Man” contou com Oberdan no sax, Márcio Montarroyos e Darcy da Cruz nos trompetes, José Roberto Bertrami nos teclados, Alexandre Barbosa (Mamão) na bateria, Alex Malheiros no baixo e na guitarra, Wilson das Neves na percussão, entre outros músicos. O grupo chegou a se apresentar ao vivo poucas vezes, em shows realizados em bailes da SGP, variando os integrantes, como Chico Batera, Jamil, Cristóvão Bastos, Edson Maciel, Cláudio Stevenson e Barrozinho, segundo Motta (1976, p. 38). A Hot Stuff Band não teve continuidade, mas serviu como inspiração, em termos de mistura e experimentação musical, para a criação da Banda Black Rio, naquele mesmo ano.

“Ju Ju Man”, inicialmente composta como uma peça de jazz fusion, misturava elementos do jazz, do soul e do rock. A guitarra elétrica é a referência principal, ao lado do baixo elétrico, que ganha destaque em solos vigorosos. A bateria também ganha espaço com pulsação mais próxima ao rock do que a gêneros tradicionais do jazz, como o bop. A influência de Miles Davis 
é notável, já que o músico foi um dos precursores do fusion, antes chamado de jazz-rock, especialmente pela substituição dos instrumentos acústicos pelos eletrônicos, abrindo mão da improvisação para dar lugar a ritmos mais quadrados, reiterativos e dançantes. A introdução de sonoridades e timbragens afro-brasileiras na gravação despertou o interesse do Passport, que, no ano seguinte, fez um disco em homenagem ao Brasil (Iguaçu, 1977), que contou com a participação de vários músicos brasileiros - dentre eles, o baterista Wilson das Neves.

A música mais famosa do álbum é "Respect", de Aretha Franklin, a segunda faixa do lado B, que parece ter sido propositalmente escolhida para representar o ponto alto do baile. O hit lançado em 1967 e composto por Otis Redding é o maior sucesso de Aretha Franklin, que se tornou também uma espécie de hino do feminismo e do movimento pelos direitos civis nos EUA. A letra, escrita por Redding, teve seu eu-lírico modificado do masculino para se adequar à voz feminina, em que a cantora exigia respeito de seu companheiro, cujo canto revelava aspectos da técnica vocal do gospel, exortando as audiências a cantar e a agir. A canção foi incluída no disco de estreia de Aretha na Atlantic, I never loved a man the way I love you (1967), liderando as paradas de sucesso, tanto de $\mathrm{R} \& \mathrm{~B}$ quanto de pop, durante várias semanas. A "rainha do soul" iniciou sua trajetória cantando jazz, mas aderiu ao soul ao assinar contrato com a Atlantic em 1966, lançando inúmeros discos de sucesso, considerados clássicos pela imprensa especializada, e que fizeram com que Aretha vendesse mais discos do que qualquer outro artista negro norte-americano. (BRACKETT, 2009, p. 65)

A canção seguinte, "The ghetto", de Donny Hathaway, era mais uma faixa que demarcava a afiliação ao soul clássico da SGP. Uma versão reduzida, com cinco minutos e um pouco diferente da original (com sete minutos), foi selecionada para integrar a coletânea. A canção, cuja letra nada mais é do que uma sucessiva repetição da expressão "the ghetto", é entremeada por frases, interjeições e sons que reproduziam as sonoridades das ruas de um bairro negro, como conversas e o choro de um bebê. A batida dançante era inspirada no latin jazz, especialmente presente na utilização de congas cubanas. Hathaway era um músico e compositor talentoso, trabalhou com importantes nomes do soul, como Aretha Franklin e Curtis Mayfield, e teve uma curta 
trajetória, falecendo precocemente aos 33 anos, em 1979. Mas foi uma das grandes sensações da soul music, com sua voz suave de inflexão gospel e romântica. Seus duetos com Roberta Flack fizeram enorme sucesso - "Where is the love" (1973) e "The closer I get to you" (1978). Donny Hathaway era um representante do soul de Chicago, um estilo mais suave em relação ao hard soul ou ao southern soul. Apesar de manter a influência do canto gospel, as gravações seguiam harmonias mais doces e descontraídas, com cantores altamente melodiosos e com um apelo mais pop. Outros artistas associados ao soul de Chicago eram Chaka Khan, Earth, Wind \& Fire e The Emotions.

"If you can't be in love" (1976) é outra canção lenta e romântica do disco da SGP. Os Spinners começaram sua carreira em Detroit, sendo contratados inicialmente pela Motown, depois indo para a Atlantic. Foi um dos grupos vocais de $\mathrm{R} \& \mathrm{~B}$ mais famosos do período, considerado representante do easy listening, pop orquestral, ou da chamada adult contemporary music, rótulos que englobavam baladas mais lentas e suaves, que podiam servir de fundo musical relaxante e agradável. Na mesma chave melódica, a próxima canção do álbum, "Grateful" (1976), do quinteto vocal Blue Magic, um dos principais conjuntos do Philly soul, também é uma balada romântica, cantada em falsete, uma marca das canções do período, ao estilo do cantor Barry Gibb, dos Bee Gees, e do grande ícone do soul Al Green. A última canção do álbum é outra gravação de Aretha Franklin, "Until you come back to me”, lançada no ano de 1973, que posteriormente integrou o álbum da cantora Let me in your life, em 1974, que teve participação do músico brasileiro Eumir Deodato, tocando piano elétrico. Composta por Morris Broadnax, Clarence Paul e Stevie Wonder, vendeu um milhão de cópias nos EUA.

\section{Música altamente dançável}

Não apenas os discos da SGP, mas todas as coletâneas assinadas pelas equipes eram compostas por músicas americanas, não havendo espaço para cantores brasileiros. Como discutido anteriormente, o consumo de discos importados era uma marca da cena black carioca, não só em resposta à penetração no mercado nacional de música estrangeira. Mas demarcava também um impulso distintivo a partir do contato com uma produção globalizada, 
cosmopolita, anglófona, em que o inglês era compreendido como a língua que possibilitaria um ingresso na modernidade ocidental. No entanto, quase não existia conhecimento no idioma entre os participantes dos bailes, que ouviam e dançavam os sucessos do soul e do funk sem atentar para o conteúdo das canções, mais interessados no ritmo e na prática da dança. André Garcia Braga (2015), em sua tese sobre a circulação de vinis no contexto da Black Rio, transcreve o seguinte diálogo, que ilustra bem a relação dos frequentadores dos bailes com a questão do inglês.

Andre: Vocês entendiam as letras das músicas em inglês ou procuravam saber ou traduzir elas [sic]?

DJ Ricardo: Eu nunca entendi nada, ninguém sabia nada. Eu não sei inglês até hoje... a gente cantava o que achava parecido. Mas o que interessa mesmo é o ritmo, a batida, a letra não importa... Andre: Nem nas músicas conhecidas do James Brown?

DJ Ricardo: Olha, James Brown é bom pra dançar. As músicas que mais bombavam nos bailes eram 'Pick Up The Pieces', 'Pass The Peas' e 'Sex Machine' e eu acho que nenhuma delas tem essa mensagem racial. Mas podia tocar qualquer uma do James Brown ou dos JBs que o salão vinha abaixo, independentemente de ter ou não uma mensagem racial. (BRAGA, 2015, p. 104-105)

Partilhar a escuta de canções, mesmo que a mensagem contida nas letras não estivesse acessível, dançar, paquerar, consumir bebidas, dividir um espaço e performatizar um estilo faziam também parte do ritual dos bailes black, que eram deliberadamente espaços para a manifestação de um sentimento compartilhado dos sentidos criados em torno do que significava ser jovem e negro - no contexto da cena musical. A celebração e a festa possibilitavam a experiência musical e o exercício de novas sociabilidades por meio do corpo e da dança, pois a música jovem é, acima de tudo, dançável. (TROTTA, 2006, p. 34) No contexto da cena da Black Rio, a mensagem musical não era o principal, pois o vetor da juventude se encontrava depositado no ritmo, que era a base sensorial para a partilha de sensibilidades em torno de uma ideia de juventude - e, no caso do soul, de negritude - como aponta Trotta (2006, p. 34): 


\begin{abstract}
Musicalmente, a música jovem apresenta uma forte base rítmica que quase sempre reforça a pulsação, isto é, seus desenhos rítmicos são articulados nos pontos de apoio do compasso. O amor simples e idealizado do jovem e a batida energética da base rítmica se completam com uma estrutura harmônico-melódica direta, com poucos elementos de contraste e/ou quebra de expectativas. Todos esses elementos musicais são reforçados por uma atitude dos artistas que colaboram para uma valorização da 'energia', da 'vida' e da 'felicidade’, representadas na estética jovem.
\end{abstract}

A música jovem também é reiterativa, o que favorece a performatização de passos de dança e o engajamento corporal de maneira criativa e espontânea. O corpo, nos bailes soul, se tornava um documento que assinalava uma identidade negra acionada na dança e nos gestos, mobilizando a exibição de uma subjetividade construída. A performance e o estilo efetivado por meio de um conjunto variável de mediações permitiam, pois, a corporificação e materialização de uma identidade no engajamento do corpo na dança, que tornava sensível a consciência da diferença. A música juvenil se mostra, dessa maneira, como um territorio fundamental de produção de estilos e de atos críticos, enfatizando conflitos e diferenciações que não podiam mais ser ocultadas.

Em um primeiro momento, os bailarinos tentavam copiar os passos de celebridades como James Brown, Michael Jackson, Tony Tornado e Gerson King Combo em danças mais individualizadas e improvisadas, que recorriam, frequentemente, a formas de movimentação mais associadas a posturas masculinas, como braços esticados, chutes, meneios dos joelhos e pés, passos aéreos e acrobacias energéticas, abrindo espaço para a criatividade dos dançarinos. Um dos passos mais executados era o "espaguete", um "abrasileiramento" para spacatto, também chamado de grand écart - nomenclaturas ligadas ao universo do balé -, que consistia na abertura total das pernas, uma para frente e a outra para trás, até o chão, movimento que exigia bastante esforço e flexibilidade. Para facilitar o deslizamento dos pés no chão da pista, muitos dançarinos aplicavam graxa às solas dos sapatos, ou então, como mencionado anteriormente, fixavam chapas de metal aos saltos que facilitavam a execução do passo chamado "agilidade no sabonete”. (RISÉRIO, 1981) 
O dançarino Nelson Triufo, um importante personagem da cena black de São Paulo, narra como os passos de funk foram introduzidos nos bailes:

Na época para a gente a dança não tinha muita técnica, digamos que a gente olhava os movimentos e copiava, depois que começamos a entender que existiam contagens, os aquecimentos, na época a gente não se aquecia não, já chegava dançando, o aquecimento era a própria dança, hoje não, hoje tudo é mais técnico, antes era mais uma forma de tirar um barato, curtir, apesar de já estar aparecendo em televisão, mas hoje não [...]. (COLOMBERO, 2011, p. 7)

Os passos de dança executados nos bailes brasileiros eram mimeses de danças de rua negras norte-americanas, como o locking, estilo de dança criado pelo bailarino e coreógrafo Don Campbell - também conhecido pelo nome artístico Campbellock -, que fazia parte do elenco de dançarinos do programa Soul Train. O locking foi inspirado nos passos do funky chicken, dança popularizada pelo cantor de soul Rufus Thomas, que lançou a canção "Do the funky chicken" (1969) e se baseava em movimentos ritmados laterais de quadril e joelhos, que se abriam e fechavam, conjugados com elaborados giros com os braços. ${ }^{14}$

Geralmente, as danças de rua ou danças populares negras norte-americanas permitiam mais improvisações e introdução de traços particulares, com mais liberdade. Foi o que ocorreu com as danças ligadas ao funk e ao soul, a exemplo do locking. Don Campbell não conseguia executar adequadamente os passos do funky chicken com fluência e rapidez e acabou desenvolvendo um estilo de dança cujos passos amplos e acrobáticos eram executados de modo interrompido, contraindo os membros como se eles estivessem sendo travados (locking). As pausas acompanhavam os tempos fortes das batidas do funk, congelando as modulações corporais, que eram executadas com

14 O funky chicken foi baseado na dança the chicken, bastante popular nos EUA na década de 1950, em que os dançarinos batiam os braços, rebolavam e movimentavam os joelhos, em uma espécie de imitação de uma galinha. Uma versão dessa dança ficou conhecida no Brasil através do apresentador de TV Gugu Liberato, na ocasião da gravação da música "Baile dos passarinhos", no começo dos anos 1980 . 
extrema rapidez e em continuidade. Campbell acabou por criar um dos primeiros grupos de street dance de que se tem notícia, o The Lockers, em Los Angeles. Seus passos de dança influenciaram toda uma geração e inspiraram também a coreografia de John Travolta em Saturday night fever (1977), já durante a era disco. A partir do locking, outras danças foram sendo criadas, como o roboting ou robot shuffle - no Brasil, os blacks chamavam a dança de "o robozinho" -, que reproduziam os movimentos mecânicos de um robô, com braços contraídos e pernas esticadas, sem articular os movimentos. Já o popping foi criado por Sam Solomon (Boogaloo Sam), na Califórnia, cujos movimentos eram baseados em rápidas contrações e relaxamentos dos músculos, que empurravam o corpo do dançarino em impulsos bruscos sincronizados com as batidas da música (ou pops), de forma contínua e combinada com vários outros movimentos e poses. Esse estilo de dança foi popularizado em todo o mundo por Michael Jackson e também possibilitava a realização de acrobacias, saltos, giros no chão e movimentos de joelhos.

Essas danças básicas passaram a incluir movimentos característicos da dança de rua que são praticados até os dias de hoje, como os waves - em que ombros e braços esticados em linha realizam um movimento ondulatório em continuidade -, boogaloos ou boog style - movimentos mais fluidos e circulares, que davam a ilusão de um corpo sem ossos ou com articulações moles e soltas, que envolvia tremulações de cabeça, quadris e joelhos, bem como deslocamentos e caminhadas em passos mais elaborados -, o passo the running man - em que o dançarino simula uma corrida sem sair do lugar, deslizando os pés no chão e jogando os braços flexionados para frente e para trás - e o famoso moonwalk, eternizado por Michael Jackson, inspirado em passos já praticados na comunidade afro-americana desde os anos 1930. O moonwalk - também chamado de backslide - faz parte de um conjunto de técnicas que criam a ilusão de que o bailarino está flutuando sobre o chão, deslizando os pés, como se caminhasse para trás.

Esses passos e movimentos mais célebres e complexos eram performatizados por dançarinos mais experientes e talentosos dos bailes, pois exigiam certo treino. Muitas vezes, abriam-se rodas no meio da multidão para que um determinado bailarino solasse no centro do espaço, uma prática usual também em outros contextos brasileiros populares, como o samba de roda 
e o jongo, como lembra Vianna (1987, p. 96): "O solista escolhe quem vai substituí-lo no centro. Esse é o único momento do baile em que aparece o dançarino solo, mesmo assim rodeado por um grupo de amigos, que também controla o tempo de sua dança 'solitária”. A performance da dança, assim, ganhava contornos coletivos e individuais ao mesmo tempo. O centro da roda era o espaço para a execução dos melhores passos, e, geralmente, o bailarino puxava pelo braço o próximo que irá ocupar seu lugar, sucessivamente. Essa prática dava destaque aos dançarinos mais habilidosos, que chegavam a ficar famosos e, eventualmente, podiam ser convidados pelas equipes para dançar profissionalmente nos bailes, incentivando também o surgimento de novos talentos por meio dos concursos de dança. As coreografias criativas também acompanhavam, dentro e fora dos bailes, a criação de comprimentos elaborados e gestos que identificavam os blacks entre si e que distinguiam também os seguidores de cada equipe, que funcionavam também como espécies de associações ou clubes.

Mais negros chegam e se cumprimentam num ritual de gestos, punhos tocando-se ligeiramente dentro de uma sequência mímica, tanto mais complicada quando maior é o conhecimento das pessoas ou dos grupos entre si. O mais simples é apertar fortemente a mão do parceiro, por baixo, um segurando o polegar do outro. (FRIAS, 1976, p. 5)

Posteriormente, começou a chegar aos bailes cariocas a tendência das coreografias coletivas, mais simples, em que os dançarinos se posicionavam em linhas para executar os mesmos passos em sincronia. A popularização desse formato pode ter vindo dos grupos que acompanhavam as equipes, como o Angola Soul, ou de grupos formados por dançarinos amadores, que se reuniam para participar de concursos e acabaram ganhando fama e se profissionalizando. Foi o caso do Grupo Philadélfia, formado por Walter Bastos, Ricardo Sampaio, Edson Rocha e Marcus Vinicius, que venceu vários campeonatos e começou a se apresentar artisticamente em bailes soul. Com idades que variavam entre 21 e 26 anos, esses jovens passaram a atuar profissionalmente na cena black, elaborando coreografias que eram copiadas pelos fãs, executadas ao som de grupos de soul como The Tramps e The Commodores 
- conjunto então liderado pelo cantor Lionel Ritchie. O grupo também realizava dublagens de canções americanas de sucesso.

A execução de coreografias coletivas também era uma tradição em comunidades negras americanas, chamadas de soul line dances e também de Chicago steppin. As line dances consistiam na repetição coletiva de sequências de passos de dança de forma sincronizada, com os dançarinos alinhados e voltados para a mesma direção - cada grupo podendo conter várias filas, uma em frente à outra -, e a sequência coreográfica tem a duração de uma canção. Esse tipo de dança se desenvolveu nos EUA, influenciado pelo madison, estilo do final dos anos 1950 praticado por jovens ao som do rock'n'roll e jazz. Na década de 1970, as line dances praticadas ao som da country music se tornaram uma febre e acabaram também por chegar às pistas das discotecas e às vizinhanças negras, que adotaram a prática da dança ao som do soul e do funk. Já o Chicago steppin, ou apenas steppin, foi uma dança urbana de salão criada nos bairros negros de Chicago também na mesma época, influenciada pelo lindy hop e pelo swing dance, utilizando os mesmos giros e pegadas, mas sem piruetas, em um ritmo mais lento. A dança é praticada por pares, em oito compassos, que se encaixam na batida $4 / 4$ do R\&B e também da disco music, e influenciou a criação do hustle, dança praticada por pares nas pistas das discotecas. Chamadas no Rio de Janeiro de "passinhos", essas coreografias coletivas se tornaram a marca do posterior movimento Charme, durante os anos 1980 e 1990, praticadas até os dias atuais, e também fizeram parte do movimento do funk carioca em seus primórdios, quando ainda se dançava o funk melody, de batida menos acelerada, mais apropriada para a prática da dança - enquanto o Miami bass, que predominou nos bailes funk, era mais rápido, incentivando movimentos mais vigorosos e pulos em danças individuais.

As coreografias em grupo funcionam melhor no começo do baile, quando ainda existe espaço para o desenvolvimento. Depois de uma hora no baile, a pista já está tomada por dançarinos, que não podem mais executar passos muito complicados sem esbarrar no grupo que está ao seu lado [...]. A música também começa a ficar mais empolgante e marcada, exigindo menos sutileza e mais animação do público. (VIANNA, 1987, p. 97) 
O momento de maior intensidade do baile se referia à hora em que músicas mais famosas, mais dançantes e ritmadas eram tocadas, como narra Frias (1976): "Quando se toca a canção Soul Power, de James Brown, quase um hino, a expressão Soul Power é repetida ritmicamente pelo público de ginásios lotados num sussurro, num murmúrio, num ruído surdo e homogêneo”. Nesse ponto culminante do baile, em que a dança se tornava mais vigorosa e a excitação atingia graus máximos, os corpos ficavam mais próximos e choques eram inevitáveis. Geralmente, nessas horas, era possível notar focos de briga e alguma violência, especialmente quando gangues ou galeras, como ficaram conhecidos mais recentemente grupos de jovens que praticavam certos tipos de delinquência nos bailes funks, aproveitavam para provocar e brigar com grupos rivais. "O DJ controla conscientemente a intensidade da festa. Até mesmo as batidas por minuto de cada música são levadas em consideração", como registrou Vianna (1987, p. 49) em um baile funk nos anos 1980. O controle exercido pelos disc-jóqueis também se dava no sentido de acalmar os ânimos. O DJ trabalhava aumentando a intensidade do baile e, após uma sequência mais agitada, desacelerava o ritmo dos dançarinos, tocando músicas mais lentas. Essa sucessão poderia ocorrer em vários momentos do baile, mas era uma estratégia frequentemente utilizada para fechar a festa no final das madrugadas. 


\section{Conclusões}

Ao analisar a composição do LP da equipe SGP lançado em 1976, minha proposta foi discutir aspectos ligados à circulação dos gêneros musicais na configuração da cena Black Rio, levando em consideração constrições do mercado, aspectos musicais, circulação de valores, discursos e linguagens, bem como a inserção dessas canções nas sociabilidades e processos de subjetivação que surgiam no contexto dos bailes. Analisar o LP também foi um recurso para captar a configuração dos bailes, o clima, os momentos e o modo como os DJs e as músicas davam o tom da festa, incentivando diferentes práticas de dança que corporificavam performances e materializavam o estilo black nas pistas. Essa foi uma estratégia metodológica que permitiu compreender algumas das dinâmicas a respeito da circulação e da fruição musical na cena. E ainda possibilitou discutir como os gêneros musicais se materializavam no espaço dos bailes por meio da dança, como forma de compreender a performatização de um estilo black, que, na constituição da cena, se referia a novos modos de dramatizar uma linguagem por meio do corpo, da estética, dos passos de dança, mas que também conectava aqueles participantes a uma produção cultural globalizada. Dançar nos bailes, independente das motivações, era uma forma de estabelecer novas sociabilidades, subjetividades e também representava o exercício de uma liberdade e de novas maneiras 
de existir e de se diferenciar. Como conta Jorge, um então jovem negro de 22 anos ao ser indagado por Cavalcanti (1981, p. 7-8) sobre a maneira pela qual havia se dado sua adesão ao soul:

A primeira vez que fui a um baile 'soul', levado por amigos, me senti muito mais à vontade do que em outro tipo de festa: tinha vergonha de dançar samba em festas na Escola, pois achava difícil os passos e dançava mal; música 'soul' é só liberar os sentimentos e deixar o corpo ir junto, pode-se dançar de qualquer maneira...

Nessa fala, Jorge transmite algumas mensagens que dizem respeito à própria configuração da cena Black Soul naquele momento. Ele apontava o impulso modernizador presente na cena ao opor samba e o soul e enfatizava um ethos e uma estética jovem, que tinha um apelo rebelde e inovador, em contradição às tradições de gerações anteriores. O conflito geracional se fazia presente especialmente na maneira de performatizar o estilo por meio da dança, pois uma das particularidades das formas de dança surgidas no pós-guerra e conectadas a gêneros musicais juvenis - no caso do soul, eram danças de rua populares - era uma aparente espontaneidade na desenvoltura dos passos mesmo que, para aprendê-los, fosse preciso muito treino e habilidade. Essas novas sonoridades transmitiam a sensação de que a música teria a capacidade de conduzir o corpo com mais naturalidade do que gêneros musicais anteriores. De fato, as novas músicas jovens possibilitavam certa dose de criatividade e improvisação, já que eram dançáveis individualmente, não mais em pares, como as danças de salão.

Não obstante, no baile convergem também prazer e a norma, a expressão individual com a sanção coletiva. Os desenhos corporais adotados no baile respondem a padrões de movimento instituídos socialmente, que possuem códigos que integram sistemas normativos e valorativos, que outorgam sentido à experiência corporal, além de assinalar papeis e hierarquias sociais. (SEVILLA, 2005, p. 173, tradução nossa) 
A dança nos bailes assumia, assim, um papel comunicativo, em que o corpo organizava discursos que estabeleciam a linguagem do estilo e cujos gestos revelavam e construíam uma identidade. Sua capacidade de expressar sentimentos e afetos fazia com que a dança possibilitasse uma transcendência temporária, a partir da assunção de novos papéis e da ênfase na diferença, construindo novas experiências sensíveis e de autorreconhecimento em que corpos, cabelos, roupas e performances se convertiam em depósitos de memórias, valores e ideais. Dançar o soul no contexto da Black Rio era deleite, prazer, criatividade e entretenimento e tinha um papel de atividade lúdica e estética, performatizando um estilo que apresentava novas possibilidades de agência cultural e política. Dançar também é uma forma de performatizar uma escuta e um gosto que se apoia em técnicas, treinamentos corporais e repetições, segundo Hennion (2011, p. 263), cujo prazer momentâneo decorrente é resultado reflexivo de uma prática corporal coletiva e instrumentada, mas que abre espaço para a manifestação de atos criativos individuais como ocorriam nos bailes soul.

Enfatizar as condições de produção, circulação e reconhecimento do gênero musical do soul tomando como exemplo a compilação de canções contidas no disco da SGP foi uma forma de perceber como se configuraram as estruturas de sentimento da cena da Black Rio no que se refere às performatizações de gosto, partilhas de afetos e processos de subjetivação inscritos no território musical dos bailes. Compreender o gosto musical como um dos elementos basilares do estilo permitiu identificar modos de elaboração, tensionamentos e horizontes de expectativa criados a partir da cena musical, percebendo como diferentes narrativas foram desenvolvidas na reconstituição de experiências subjetivas engendradas no contexto da Black Rio. Assim, foi possível articular possíveis efeitos dos dispositivos sociais aos desejos e esperanças dos integrantes da cena (CARDOSO FILHO; OLIVEIRA, 2013), compreendendo como as experiências sensíveis materializadas no estilo puderam oferecer novas expectativas para políticas culturais em torno das questões de raça e classe no Brasil.

Nesse processo de apropriação, rearticulação e criação seletiva na dramatização da linguagem do estilo e na estilização retórica do corpo por meio da performance, os blacks desenvolveram estratégias alternativas de ocupação 
de um espaço social alheio, potencializando uma autoexpressão por meio do cabelo, das roupas, da dança e de uma postura como forma de constituir e sustentar o companheirismo e a comunidade. (HALL, 2003, p. 343) Na renovação de um repertório cultural negro brasileiro a partir da sobredeterminação subversiva de traços estéticos diaspóricos, míticos e flutuantes no âmbito da moderna cultura popular, a cena da Black Rio apresentava novas formas de engajamentos que atravessavam fronteiras culturais, embaralhando tradições e negociando posições a partir de estratégias subterrâneas de significação crítica.

Esta pesquisa representou o desafio de empreender uma discussão conceitual em torno da noção de cena musical, chamando a atenção para o potencial das políticas de estilo como perspectiva significativa para a compreensão das transformações sociais e culturais que se transmutam em torno das experiências identitárias na cidade contemporânea. Mas, mais do que isso, minha proposta foi tentar compreender os processos que se consolidavam a partir da construção de alianças em torno de novos significados do que era ser negro naquele momento no Brasil e no mundo. Esses significados gravitavam em torno do consumo cultural popular massivo, cujos desmembramentos podem ser percebidos até os dias atuais. Assim, parti de uma perspectiva não definitiva e multidisciplinar que aponta as cenas musicais como locus de novas experiências subjetivas, espaços de organização de ações político-culturais e diferentes práticas de consumo, utilizando como exemplo o movimento Black Rio. Essa cena musical se constituiu sobre a pauta da afirmação de uma negritude cosmopolita e de uma afro-brasilidade alternativa, confrontada com experiências diaspóricas e étnico-raciais globalizadas, o que implicou difusos processos de recombinações, hibridizações e interconexões entre tradições nacionais, símbolos cosmopolitas, mercados alternativos e produtos culturais mainstream.

Após o panorama geral sobre a configuração da Black Rio, foi possível compreender como as cenas musicais materializam a ligação de um determinado grupo de ouvintes, fãs e consumidores a um território tanto geográfico quanto simbólico, conectados por atos do consumo musical coletivo e por um conjunto de valores, afetos e performances partilhadas. Esse fenômeno - rotulado pela mídia como "movimento" -, assim, pode ser entendido como 
uma cena musical ao articular diversas formas de comunicação e estratégias de ocupação de um determinado espaço, demarcando fronteiras simbólicas e identitárias. Dos bailes, surgiu um novo tipo de estilo black difundido pela cena, que unia consumo musical a usos diferenciados da dança, da moda, do corpo - criando uma estética afro - e da performance. Esse estilo se moldava e articulava diferentes condições de existência e de produção de sentidos ao criar linhas de influência e solidariedade, articulando novas estratégias interpretativas das influências culturais globais em nível local. Estruturada na articulação de alianças dinâmicas em torno do consumo cultural da música popular massiva, a Black Rio possibilitava uma vasta gama de processos de diferenciação e interação social que reforçavam demarcações de diferenças raciais e étnicas, de classe e gênero, mas mantendo vias de comunicação entre grupos culturais e comunidades de gosto dispersas (STRAW, 1991, p. 372), mesmo quando seus ecos foram amplificados, atingindo outras regiões e chegando à grande mídia.

Também aqui a noção de cena musical se apresentou como uma adequada ferramenta interpretativa no exame do fenômeno, porque dá conta não apenas das interações puramente sociais, mas também abarca lógicas de produção, circulação, comercialização e consumo, tendo em vista que os bailes representavam um novo mercado jovem, alternativo e periférico, se articulando a dinâmicas do mercado musical do período. A ideia de cena, pois, consegue enfatizar tanto o caráter híbrido e ambíguo quanto os pontos de unidade e coerência da Black Rio ao levar em consideração as transformações de forças sociais, econômicas e institucionais que afetavam essa expressão cultural coletiva e também as mecânicas sociais associadas à produção musical (FREIRE FILHO; FERNANDES, 2005, p. 6) de maneira complexa e tensiva.

Neste trabalho, ainda me propus a interpretar diversas estratégias para a demarcação da diferença promovidas no interior da cena, o que foi central para a elaboração do seu valor e significado musical, bem como para a construção de articulações entre escutas musicais, identidades, estilos e afetos. Nesse sentido, a materialização da cena da Black Rio se deu pela proposição de modos específicos de mapear, demarcar e ocupar o terreno urbano por meio de práticas musicais autorreflexivas. (JANOTTI JUNIOR, 2012a) A realização de uma espécie de cartografia dessa cena musical permitiu 
demonstrar como os bailes soul correlacionavam o consumo de gêneros musicais estrangeiros - o soul, o funk, a disco music-, naquele momento compreendidos como black music, a um território periférico urbano - os subúrbios cariocas.

Na região suburbana do Rio de Janeiro, ocupada majoritariamente por uma classe proletária subalterna negra, mas também por uma pequena emergente classe média de negros e pardos, essas festas se tornavam rituais partilhados coletivos que envolviam práticas de consumo musical e impulsos por uma diferenciação e afirmação identitária. A música popular massiva servia tanto como amálgama da expressão de afetos relativos a um pertencimento a uma comunidade racializada, quanto como a expressão de sentimentos de revolta contra o racismo, simbolizando a renúncia a um modelo de sociedade baseado em polarizações raciais ocultadas sob o manto de uma suposta democracia racial. A ideia de cena foi útil, pois funcionou como moldura analítica para compreender a lógica da formação de alianças no interior e ao redor dos bailes. Foi também um recurso importante para interpretar a rede de afiliações mais amplas que deram corpo a experiências estéticas e musicais independentes e inovadoras que transformaram as práticas musicais e culturais urbanas periféricas no Rio de Janeiro dos anos 1970.

Observar as ações dos integrantes de uma cena musical ofereceu ainda um panorama para a compreensão da experiência musical, produções de sentido e das mediações como processos importantes de demarcação e construção de vínculos identitários em torno de um território cultural. As cenas ancoram em si estruturas de sentimento que dizem respeito à partilha de experiências, gostos e afetos comuns inscritos em práticas musicais urbanas específicas, configuradas em determinados espaços significativos. Neles, diversas narrativas se entrelaçam na reconstituição de experiências subjetivas e na compreensão das dinâmicas de produção de subjetividades, que se materializam em atos de consumo cultural, estilos e performances estéticas. E na cena da Black Rio, foram essas estruturas de sentimento que fundamentaram o estilo de seus participantes. Como pontua William (1979, p. 18), as estruturas de sentimento condicionam conexões e correspondências que "mais saltam à vista”, já que a vivência é substituída pelo registro e pelos diferentes recursos de memórias residuais. São esses resíduos que permitem interpretações, 
identificações e, eventualmente, generalizações que compõem uma totalidade sempre em formação, na medida em que emergem a partir da própria experiência, cuja consciência só é perceptível com a passagem do tempo.

$\mathrm{Na}$ interpretação dessa produção subjetiva, tentei evitar um olhar mais "romantizado" sobre a constituição da cena da Black Rio, a fim de dar conta das contradições e disputas envolvidas no contexto dos bailes e das reconfigurações identitárias desencadeadas a partir deles. Esse empenho em uma "desromantização" passa justamente pela ênfase nos aspectos comunicacionais e nas relações da cena com a indústria fonográfica e com o mercado de entretenimento da época, complexificando os processos de circulação de produtos massivos e as transformações das sociabilidades no período. Ao adotar uma metodologia de pesquisa que se debruçou sobre discursos do jornalismo impresso da época e sobre entrevistas abertas com alguns atores, bem como relatos recolhidos em outras produções acadêmicas e históricas, busquei perceber a formação de estruturas de sentimentos desenvolvidas no período, configuradas a partir das políticas de estilo dos blacks e dos processos de mediações comunicativas, que geraram um horizonte de expectativas a partir do espaço de experiência dos bailes. Dada a limitada documentação da época disponível sobre o fenômeno - com pouca cobertura da imprensa, raros registros fotográficos informais e caseiros e a inexistência de material audiovisual sobre os bailes -, alguns aspectos da Black Rio não puderem ser adequadamente desenvolvidos, como embates éticos, tensões entre os atores, questões de gênero e conflitos com outros universos musicais, por exemplo. Talvez essas nuances possam ser melhor discutidas e compreendidas mediante a realização de entrevistas em profundidade com personagens da cena, o que acaba por fugir do escopo deste trabalho, mas deixo aqui como sugestão para pesquisas posteriores.

Minha proposta foi compreender o sentido político e cultural da Black Rio, que residiu em sua articulação enquanto cena musical interligando identidades, afetos e interesses de seus participantes, os quais não eram contemplados pelas instâncias hegemônicas da sociedade e acabaram por desenvolver estratégias singulares e alternativas de socialização e consumo cultural. Ao correlacionar gostos e práticas de consumo com categorias de identificação, foi possível examinar a maneira como práticas musicais específicas 
estabelecidas a partir dos bailes soul atuaram na produção de um senso de comunidade, materializado no consumo de produtos massivos e estabelecendo uma nova produção cultural periférica. Essas práticas unificavam sentimentos de participação em alianças afetivas, demarcando fronteiras híbridas para a diferença cultural do grupo de participantes da cena, que se converteram em novos atores sociais, ocupando espaços públicos da cidade, tensionando e complexificando diferentes instâncias culturais em um momento de transformação social e histórica.

Ao observar como se configurou um estilo black, pude perceber como esses atores demandavam não apenas visibilidade - já que o componente negro sempre é visível, pois é nomeado, apontado, separado, depreciado -, mas como buscavam uma nova visibilidade, mais positiva e afirmativa, que serviu como aporte significativo para a materialização e para a discussão dos aspectos políticos inerentes à cultura, ao consumo e às manifestações das identidades nos processos de comunicação e mediação. Era na arena da performatização do estilo que os blacks desafiavam as convenções de raça e cor, subvertendo também os padrões de conduta não apenas na pista dos bailes, mas na vida diária. Ao incorporar novas maneiras de se vestir, de se comportar, de usar o cabelo, de dançar, anônimos se tornavam celebridades no momento efêmero da festa, desestabilizando fronteiras entre celebridades, artistas e público, como uma metáfora para uma estética revolucionária, o que, de certa forma, representava o embaralhamento entre a arte e a realidade da vida. (HEBDIGE, 1979) O palco, ou a mídia, e as celebridades, não eram apenas os únicos centros difusores de novas modas, que passaram a ser elaboradas nos bailes, nas ruas, na vizinhança dos bairros e na partilha de novas sensibilidades e performatizações de gosto.

Para Giddens (2002, p. 16), o estilo apresenta formas de "política-vida" que lidam com autorrealizações humanas no nível do indivíduo e do coletivo, propondo novas formas de envolvimento. Essa política-vida tem relação evidente com propostas progressistas de emancipação, que são ainda fundamentais em um mundo moderno, marcado e dividido, ao mesmo tempo, por arcaicas e novas formas de opressão que solicitam diferentes práticas e manifestações de interesses políticos para se juntar aos empreendimentos políticos preexistentes. É nesse contexto que o corpo adquire o lugar de memória 
em movimentações e estéticas que sustentam rituais e performances (TAVARES, 2010, p. 81), recriando novas estratégias de referências de solidariedade e identidade.

A cena Black Rio, dessa forma, se definiu como um território político do qual emergiu uma identidade negra corporificada que rejeitava a "tropicalidade", a mestiçagem e a pretensa democracia racial. Os blacks, apesar de ambiguidades e tensões, não aceitavam uma negritude mediada pela brasilidade, se apropriando em momentos estratégicos e convenientes de um radicalismo pautado na experiência afro-americana. A identidade nacional construía uma imagem de totalidade social homogênea que não se concretizava no plano de um cotidiano demarcado pelo racismo. Nos bailes soul, os estilos de penteados e de indumentária tornaram-se importantes não apenas como marcas simbólicas, mas por estarem associados à construção de uma identidade coletiva que não mais podia ser definida exclusivamente dentro dos limites do Brasil. (HANCHARD, 2001, p. 136) As políticas de estilo dos blacks passaram a agir na transversalidade das noções hierárquicas de classe e raça e às margens das ações políticas convencionais, operando em meio às influências globalizantes e implicando um projeto reflexivo e estratégico da identidade.

A narrativa da autoidentidade deve ser formada, alterada e reflexivamente sustentada em relação a circunstâncias da vida social que mudam rapidamente, numa escala local e global. O indivíduo deve integrar informações derivadas de uma diversidade de experiências transmitidas pela mídia com envolvimentos locais de maneira a conectar projetos futuros com experiências passadas de modo razoavelmente coerente. Isso só pode ser alcançado se a pessoa for capaz de desenvolver uma autenticidade interior - um referencial de confiança básica por meio do qual a vida pode ser entendida como uma unidade contra o pano de fundo de eventos sociais em mudança. (GIDDENS, 2002, p. 198)

O estilo ajuda a criar novas narrativas da identidade, dando coerência à vida cotidiana em um contexto de transformações sociais em que o corpo se torna o local da interação, apropriação e reapropriação. (GIDDENS, 2002, p. 200) É na performance que o estilo se estrutura reflexivamente, como uma 
camada externa permeável às influências da realidade e cujas fronteiras se alteram para englobar os objetos de consumo apropriados e mobilizados na práxis da identidade. Os estilos performatizados na cena da Black Rio, pois, são expressões e reações aos desafios de uma sociedade em vias de transformação, exprimindo uma tensão progressiva entre experiência e expectativa. As categorias de espaço de experiência e horizonte de expectativa aqui disponibilizam mais do que um modelo de explicação para a gênese da cena musical em si (CARDOSO FILHO; OLIVEIRA, 2013) e remetem à ação e interação dos sujeitos, reunindo dinâmicas sociais contínuas em estruturas duradouras que se repetem em um conjunto mais ou menos integrado de práticas simbólicas que preenchem necessidades coletivas, mas também dão forma material a uma narrativa particular da identidade.

Referindo-se a uma autonarrativa, o estilo se encaixa em novas percepções individuais sobre o mundo, mas também alude à exibição de performances e rituais demarcados publicamente por meio da dança exuberante, da forma de manipulação do cabelo, da estética das roupas, como forma de imprimir na paisagem da cidade uma nova retórica comportamental, uma alteridade permeada por excessos que, naquele momento, se mostravam como um recurso estratégico para exprimir e atualizar a condição de ser negro. $\mathrm{Na}$ atualização desses elementos, o estilo black se baseava em uma "corporalidade subversiva e disruptiva”, usando expressão de Osmundo Pinho (2005, p. 132), que apresentava um desafio a padrões de gosto e valores raciais e, contraditoriamente, reproduzia estereótipos sobre seus próprios adeptos.

Essa compreensão da difusão do estilo black propõe ir além da visão que atribui trivialidade a um consumismo supérfluo, enfocando os atos conscientes de consumo cultural e musical. A ênfase no estilo se justifica no sentido de que ele engloba uma possibilidade de performatizar exteriormente uma identidade negra que é relacional e contingente, mas que é estratégica em sua possibilidade de ser compartilhada no momento do baile por negros e até não negros, pois o estilo abre uma multiplicidade de escolhas sobre como agir e também sobre quem ser em dado momento. Se as identidades culturais são relacionais e convenientes, elas possibilitam novos arranjos, a fim de garantir a sobrevivência por meio da partilha de experiências e sensibilidades. 
Na coletividade das festas, negros, brancos e mestiços celebravam um jeito de ser "black" em uma nova experiência da negritude dada não apenas em oposição - ao branco, à elite, ao mainstream midiático -, mas na negociação, nas tensões e nos diálogos estabelecidos em jogos ambivalentes de aproximação, distanciamento, choque e acomodação. Esses arranjos, no entanto, não eram novos e permitiram, por exemplo, a resistência cultural de terreiros de candomblé, irmandades religiosas, comunidades quilombolas (GONÇALVES, 2010, p. 372) e gêneros musicais como o samba, que se abriam a acordos com outros grupos como forma de subsistir e de garantir um espaço para se desenvolver.

O estilo black criava um rastro de significações distanciadas da inscrição da africanidade, cujas metanarrativas eram baseadas no nativismo e em um retorno às tradições do continente africano. Ele também rejeitava um instrumentalismo economicista e historicista fundamentado no marxismo e em suas relações com uma razão iluminista - e, portanto, eurocêntrica. Mas resgatava sentimentos compartilhados e ligados a representações canônicas e míticas da África, advindos das memórias da escravidão e do colonialismo, de forma dinâmica, renovando esse repertório imaginário e simbólico via EUA e sua produção cultural massiva afro-americana. Outras representações foram propostas, tanto para a sociedade, quanto para os próprios negros participantes da cena, a partir de ambivalências e binarismos contraditórios, criando novos significados produzidos nas interações com a contemporaneidade.

Frequentar um baile soul, para um jovem negro, naquele momento, significava estar em um local no qual sua beleza seria valorizada, sua performance seria reconhecida e era possível se exibir e apreciar os outros em suas potencialidades. Para uns, era uma oportunidade de ostentar bens e demonstrar um poder aquisitivo que permitia a aquisição de acessórios, sapatos e roupas. O capital simbólico adquirido também se referia à manifestação de informações e conhecimentos, seja sobre artistas, músicas e lançamentos do cinema, seja sobre os melhores bailes, os passos de dança mais difíceis, formas de cumprimento e saudação intrincados e elaborados, que poucos poderiam dominar. Ainda existia espaço para exibir a criatividade na forma de manipular os cabelos de diferentes maneiras, buscando originalidade e diálogo com as novas tendências estéticas. E havia também aqueles que começavam a 
entrar em contato com organizações ativistas negras, participando de ações políticas e se envolvendo mais decisivamente com a militância. Várias etapas que permitiam a assunção de um protagonismo e um sentimento de pertencimento, agenciando trocas de experiências e referências entre os grupos, permitindo a manifestação de um orgulho racial. Esses laços de sociabilidade favoreciam a experimentação de uma vida pública distanciada da desigualdade racial, da pobreza, da repressão e de outros problemas. Aos não negros, como mestiços e brancos integrantes da classe trabalhadora frequentadores dos bailes de soul, a questão étnico-racial poderia não ser necessariamente um valor passível de compartilhamento. Mas participar de uma experiência constituída em torno de valores positivos ligados às festas e à vida suburbana, como solidariedade, companheirismo e espontaneidade, e partilhar de uma produção cultura popular compreendida como jovem e cosmopolita representavam um fator fundamental de atração.

Ao cantor Rufus Thomas é atribuído o comentário "Se você fosse negro por um sábado à noite, você nunca mais iria querer ser branco novamente". (OSTENDORF, 2000, p. 223) Naquele momento, essa frase fazia sentido tanto para brancos quanto para negros, efetivamente. Para negros, participar dos bailes soul era se deparar com uma noção de negritude mais "verdadeira" e afirmativa do que, por exemplo, a encenada nas escolas de samba cariocas. Ser black concedia uma positividade maior à identidade negra, pois era articulada a signos da contemporaneidade e à ideia de luta contra o racismo, em oposição à uma "identidade sambista", compreendida como agregadora, mestiça e, naquele contexto, menos legítima. O soul também possibilitava que os jovens negros não mais almejassem uma beleza e uma aparência "branca", deixando de alisar o cabelo e buscando uma moda particular, na construção de uma experiência identificada como "mais negra" e vista como mais autêntica.

Para um jovem branco, fazendo uma inversão do título do livro de Sovik (2009), no baile, "todo mundo era negro". Se assumir como "black" ou se alinhar a esse estilo na efemeridade do ritual da festa simbolizava partilhar de uma negritude ainda assim mestiça, só que mais ambígua. "Sou white, mas sou black", disse um jovem a Lena Frias (1976, p. 5), descrito pela jornalista como branco e "[...] inteiramente afastado de valores culturais tidos como 
de brancos e identificados como 'coisa de rock'. Seus amigos do morro da Saúde são todos negros, e ele usa as roupas típicas dos black, sapatões soul”. O consumo desse estilo "negro" parecia ser o "equivalente simbólico de um moderno prestígio urbano” (HALL, 2003, p. 38) e, mesmo que de maneiras ambivalentes, representava um desejo de comunhão com uma ideia de coletividade e autenticidade que outras formas culturais não apresentavam naquele momento. De maneira geral, para brancos e negros, frequentar as festas soul semanais, seguir equipes, reencontrar amigos, descobrir novas músicas e dominar o repertório cultural ligado ao soul era uma forma de participar de uma estrutura associativa que gerava diferentes possibilidades de exercícios de autonomia, criatividade e de expressão subjetiva que em outras esferas da sociedade não seria possível. Era legal "ser black", e esse sentimento era catalisado pelo soul.

Para a juventude negra, os bailes davam espaço para uma autodeterminação a partir da escolha consciente de elementos para compor seu estilo e para a criação de um espaço próprio, no qual podiam participar de novas esferas públicas e culturais da cidade. No plano da estética, no contexto da cena da Black Rio, ser negro, ou melhor, ser black era um ideal valorizado, mas por razões distintas. Ora porque esse novo significante negro assumia um valor positivo ao ser associado a imagens de alegria, espontaneidade, sensualidade, força e juventude; ora por se apresentar como uma negritude alternativa, flutuante e cosmopolita, que poderia acenar para um novo futuro para as relações e políticas raciais no Brasil. Vovô do Ilê, presidente do bloco afro Ilê Ayê, em depoimento a Risério (1981, p. 19), apontou um horizonte para essa nova tendência: "A nossa mensagem maior é a festa, o espetáculo. O pessoal do Movimento Negro se reúne, se reúne, e não faz nada. E nós, através do carnaval, sem fazer discurso nenhum, já conseguimos modificar muita coisa por aqui”. Da mesma forma que o Carnaval, os bailes soul se mostravam como eventos de profunda mobilização política pautados pela cultura, pelo consumo e pelo lazer.

Compartilhar do estilo black permitia que essa identidade fosse performatizada por não negros, mesmo que isso não derrubasse hierarquias raciais fora do território significativo do baile. Mas representava uma rasura nas relações de cor, na medida em que reafirmava uma contradição às noções 
tradicionalmente associadas ao negro brasileiro, apresentando novos valores e novos discursos na esfera pública. Essa subversão era política, tanto quanto a forma com que os participantes da cena utilizavam a música popular massiva como uma prática contestatória, bem como o lazer, a sociabilidade, o prazer e o ócio. Essas instâncias eram apropriadas como maneiras de afirmar uma possibilidade de existência social apartada da discriminação e da desigualdade vivenciada cotidianamente na sociedade, exercitando uma autoestima que, mais do que valorização de uma beleza, apontava para novos exercícios de cidadania.

No universo da cultura e da música popular, da mesma forma que no campo das religiões, a maior presença e valorização de atores sociais negros promovem uma outra experiência da identidade negra, que pode ser vivenciada e negociada com mais tranquilidade do que em outros campos da vida cotidiana, como no mundo do trabalho, da escola, das instituições civis e mesmo na arena política convencional. Da adaptação criativa de produtos culturais, das formas celebratórias culturais e dos processos de "comodificação" da cultura desenvolvidos na cena Black Rio, emergiu um estilo que seria também uma estratégia de compensação para a falta de poder e de controle sobre outros aspectos da vida. Controlar, reelaborar, transformar o corpo por meio do estilo, como aponta Giddens (2002, p. 80), implicaria praticar escolhas dentro de uma pluralidade de opções e possibilidades, que se referiam a decisões estratégicas não só sobre como agir, mas também sobre quem se objetiva ser na construção da autoidentidade. O corpo inscreve condições de vida e marcas de pertença a determinadas convenções sociais e culturais ligadas à diferença, que são vividas no plano histórico e material. Nessa corporeidade, a cor da pele, traços do rosto, tipos de cabelo conformam uma subjetividade que, quando assumidos em sua originalidade, adquirem um sentido de enfrentamento, de luta, de não submissão a outros padrões estéticos, reafirmando uma manifestação de liberdade dentro de um contexto ainda precário de desigualdade e exploração. Essa condição correspondente à assertiva "negro é lindo" é uma forma profunda de desafiar hierarquias de cor, confrontando o projeto de valorização da democracia racial através do elemento mestiço, interferindo no cenário social por meio da festa e de um estilo espetacular, 
subversivo e desviante da norma. Isso convocou um debate público sobre a questão racial, deflagrando a bandeira da beleza e da autoestima.

Se o samba inferia em uma oposição tensiva e ambígua entre morro e asfalto, o soul traduzia uma outra dualidade entre subúrbio e Zona Sul, apontando para novas configurações das classes médias e proletárias e incentivando diferentes apreensões da cultura urbana popular, em que manifestações tradicionais são realocadas em prol de marcas da contemporaneidade e do cosmopolitismo. Os bailes soul também implicavam relações paralelas que, por vezes, se intercruzavam entre o regional e o local e entre uma cultural mainstream e uma produção periférica. De fato, a cena da Black Rio não implicava uma ação contracultural, pois sua configuração estava intimamente ligada ao estabelecimento de novos mercados, propondo uma inserção e não um dissenso, mesmo que, em dados momentos, articulasse ações disruptivas ou oposicionais em relação aos mercados, à mídia e a outros grupos sociais e geracionais.

O ingresso na cultura global, para os participantes da cena Black Rio, se dava pela apropriação seletiva de imagens da cultura anglo-saxônica e de símbolos de uma cultura burguesa, de acordo com conveniências na construção de uma identidade negra positiva. O propósito era abandonar progressivamente signos que identificassem o grupo com um passado tido como primitivo, atrasado, ultrapassado, a fim de garantir uma produção cultural conectada com novas tendências. Mas sem negar signos diacríticos como valores míticos africanos e reverenciando, ainda que tensivamente, tradições brasileiras, como o samba, como forma de demarcar os contornos da alteridade. As formas culturais produzidas nos bailes atravessavam fronteiras e circulavam pela sociedade, sendo transformadas em sinais manifestos de rebelião cultural e excentricidade social, despertando críticas, mas também fascínio entre outros grupos que auxiliaram na difusão pública de um estilo particular. A cena Black Rio, assim, se transformava em uma "máquina de identidade coletiva”, em uma apropriação da expressão de Wacquant (2004), que reafirmava uma alteridade a partir da criação de padrões de cognição e conduta que alimentavam um motor de combustão cultural que dissipava possíveis divisões dentro daquela comunidade, alimentando um orgulho coletivo. 
Por meio dos bailes soul, a identidade negra passou a ser desenvolvida em busca de uma nova cidadania, particularmente articulada a formas culturais populares de massa e a atos simbólicos de consumo. Esses novos exercícios subjetivos refletiam um impulso rumo a um protagonismo civil, que se relacionava a profundas transformações na intimidade, apresentando novas maneiras de refletir sobre si e sobre o mundo, em que possíveis revoluções passaram a encontrar espaço no cotidiano.

O estudo e interpretação dessa cena musical, indo além do seu caráter celebratório e de lazer, podem auxiliar na compreensão da construção de uma estrutura comunicativa e de um repertório simbólico que transcendeu as fronteiras dos bailes, estabelecendo um diálogo entre diferentes atores e estruturas sociais no contexto urbano. Os blacks, por meio do estilo, questionavam, de forma criativa, as hierarquias sociais e raciais brasileiras, ampliando e redefinindo as ideias a respeito de cidadania e apontando para novas políticas culturais. Espero, dessa maneira, contribuir para a compreensão das interconexões entre práticas musicais, consumo cultural e ocupação de territórios urbanos significativos, reconhecendo o papel fundamental de experiências estéticas, sensibilidades e mediatizações na constituição das cenas musicais como espaços da afirmação, representação e negociação de diferenças. 


\section{Referências}

ALBAGLI, S. Território e territorialidade. In: LAGES, V.; BRAGA, C.;

MORELLI, G. Territórios em movimento: cultura e identidade como estratégia de inserção competitiva. Brasília, DF: Sebrae; Rio de Janeiro: Relume Dumara, 2004.

ALBERTI, V.; PEREIRA, A. A. Movimento negro e "democracia social” no Brasil: entrevistas com lideranças do movimento negro. Rio de Janeiro: CPDOC, 2005. Disponível em: <https://bibliotecadigital.fgv.br/dspace/bitstream/ handle/10438/6829/1504.pdf? sequenc e=1\&isAllowed=y>. Acesso em: 4 mar. 2016.

ALBERTO, P. When Rio Was Black: Soul music, National Culture, and the Politics of Racial Comparison in 1970s Brazil. Hispanic American Historical Review, Durham, v. 89, n. 1, p. 3-39, 2009.

ALBERTO, P. L. Terms of Inclusion: Black Intellectuals in Twentieth-Century Brazil. Chapel Hill: University of North Carolina Press, 2011.

ALLMUSIC. São Francisco: All Media Network. 2016. Disponível em: <http:// www.allmusic.com/>. Acesso em: 10 jan. 2016.

ALMADA, S. O dom de ser negro: Dom Filó e Cultne na Revista Raça Brasil. Cultne, Andarai, 20 fev. 2013. Disponível em: <http://www.cultne.com.br/o-domde-ser-negro-dom-filo-e-cultne-na-revista-raca/>. Acesso em: 24 ago. 2015. 
ALONSO, G. O píer da resistência: contracultura, tropicália e memória no Rio de Janeiro. Achegas.net, Rio de Janeiro, n. 46, jan./dez. 2013. Disponível em: <http:/| www.achegas.net/numero/46/gustavo_alonso_46.pdf>. Acesso em: 6 dez. 2015.

ALONSO, G. Quem não tem swing morre com a boca cheia de formiga: Wilson Simonal e os limites de uma memória tropical. Rio de Janeiro: Record, 2011.

AMARAL, P. M. G. do. Estigma e cosmopolitismo na constituição de uma música popular urbana da periferia: etnografia da produção do tecnobrega em Belém do Pará. 2009. 245 f. Tese (Doutorado em Música) - Instituto de Artes, Universidade Federal do Rio Grande do Sul, Porto Alegre, 2009.

ASSEF, C. Todo DJjá sambou: a história do disc-jóquei no Brasil. São Paulo: Conrad, 2003.

BAHIANA, A. M. Enlatando a Black Rio. In: BAHIANA, A. M. Nada será como antes: MPB nos anos 70-30 anos depois. Rio de Janeiro: Ed. Senac Rio, 2006. p. 303-310.

BAHIANA, A. M. Importação e assimilação: rock, soul, discotheque. In: BAHIANA, A. M.; WISNIK, J. M.; AUTRAN, M. Anos 70: música popular. Rio de Janeiro: Europa, 1980. p. 41-51.

BAILE FUNK. Programa Legal. Direção: Guel Arraes, Belisário França. Rio de Janeiro: TV Globo, 1991. Programa de TV. 39 min.

BARRETO, A. S. Sobre palanques e palcos: showmícios e política na Baixada Fluminense. In: VELHO, G. (Org.). Rio de Janeiro: cultura, política e conflito. Rio de Janeiro: J. Zahar, 2007.

BARTHES, R. Mitologias. 4. ed. Rio de Janeiro: DIFEL, 2009.

BAULCH, E. Gesturing elsewhere: the identity politics of the Balinese Death/ Thrash Metal scene. Popular Music, Cambridge, v. 22, n. 2, p. 195-215, 2003.

BRAGA, A. G. A cena Black Rio: circulação de discos e identidade negra. 2015. 136 f. Dissertação (Mestrado em Antropologia Social) - Universidade Federal do Rio Grande do Norte, Natal, 2015.

BELLUZZO, G.; SILVA, J. (Org.). DAMT: design, arte, moda e tecnologia. São Paulo: Edições Rosari, 2010. Disponível em: <http://sitios.anhembi.br/damt6/ arquivos/07.pdf>. Acesso em: 27 dez. 2015. 
BERGER, H. Metal, rock and jazz: perception and the phenomenology of musical experience. Hannover: Wesleyan University Press, 1999.

BERNARDES, L.; SOARES, M. T. de S. Rio de Janeiro: cidade e região. Rio de Janeiro: Secretaria Municipal de Cultura, 1995.

BESSA, V. de A. À escuta da cidade: Pixinguinha e a paisagem sonora carioca da Primeira República. RITA, Montreuil, n. 1, dez. 2008. Disponível em: <http:/| www.revue-rita.com/content/view/25/51>. Acesso em: 21 jan. 2016.

BHABHA, H. K. O bazar global e o clube dos cavalheiros ingleses. Rio de Janeiro: Rocco, 2011.

BHABHA, H. K. O local da cultura. Belo Horizonte: Editora da UFMG, 1998.

BHABHA, H. K. O terceiro espaço: uma entrevista com Homi Bhabha (Jonathan Rutherford). Revista do Patrimônio Histórico e Artístico Nacional, Rio de Janeiro, v. 24, p. 34-41, 1996.

BLACK RIO. Revista Veja, São Paulo, p. 156-160, 24 nov. 1976.

BRACKETT, D. Música soul. Opus, Goiânia, v. 15, n. 1, p. 62-68, jun. 2009. Tradução de Carlos Palombini.

BRACKETT, D. Questions of Genre in Black Popular Music. Black music Research Journal, [Chicago], v. 25, 2005.

BRASIL. Decreto-Lei no 314, de 13 de março de 1967. Define os crimes contra a segurança nacional, a ordem política e social e dá outras providências. Diário Oficial [da] República Federativa do Brasil. Brasília, DF, 13 mar. 1967.

BRITTO, P. H. A temática noturna no rock pós-tropicalista. In: DUARTE, P. S.; NAVES, S. C. Do samba canção à Tropicália. Rio de Janeiro: Relume Dumará, 2003.

BONI, V.; QUARESMA, S. J. Aprendendo a entrevistar: como fazer entrevistas em Ciências Sociais. Em Tese, Florianópolis, v. 2, n. 1 (3), p. 68-80, jan./jul. 2005. Disponível em: <https://periodicos.ufsc.br/index.php/emtese/article/ viewFile/18027/16976>. Acesso em: 10 abr. 2016.

BOURDIEU, P.; WACQUANT, L. On the Cunning of Imperialist Reason. Theory, Culture \& Society, London, v. 16, n. 1, p. 41-58, 1999.

CANDEIA (1935-1978). Revista Veja, São Paulo, p. 135, 22 nov. 1978, 
CARDOSO FILHO, J. O cultivo retórico da escuta. In: ENCONTRO ANUAL DA COMPÓS, 23., 2014, Belém. Anais... Belém: UFPA, 2014.

CARDOSO FILHO, J. Disputas de valor na música popular massiva: política, estética e cultura. Revista Perspectiva Histórica, Salvador, v. 4, n. 6, p. 67-83, 2015.

CARDOSO FILHO, J. Poética da música underground: vestígios do Heavy Metal em Salvador. Rio de Janeiro: E-papers, 2008.

CARDOSO FILHO, J. Para apreender 'a experiência estética: situação, mediações e materialidades. Revista Galáxia, São Paulo, n. 22, p. 40-52, dez. 2011.

CARDOSO FILHO, J.; OLIVEIRA, L. X. de. Espaço de experiência e horizonte de expectativas como categorias metodológicas para o estudo das cenas musicais. Trans: Revista Transcultural de Música, Barcelona, n. 17, p. 1-19, 2013.

CARILLO, J. Entrevista com Beatriz Preciado. Revista Poiésis, n. 15, p. 47-71, jul. 2010.

CARONE, H. Um chefão das arábias. Jornal do Brasil, Rio de Janeiro, 1 dez. 1985. Revista de Domingo.

CARRERA, F. A.; OLIVEIRA, L. X. "Cabelo de Bombril”? Ethos publicitário, consumo e estereótipo em sites de redes sociais. Revista Novos Olhares, São Paulo, v. 2, n. 1, p. 67-75, 2013. Disponível em: <http://www.journals.usp.br/ novosolhares/article/view/57042/60038>. Acesso em: 10 jan. 2015.

CAVALCANTI, L. Black-Breque: estudo de um grupo "soul” em relação a adeptos do samba. In: ENCONTRO ANUAL DA ASSOCIAÇÃO NACIONAL DE PÓSGRADUAÇÃO E PESQUISA EM CIÊNCIAS SOCIAIS (ANPOCS), 5., 1981, Nova Friburgo. Anais... Rio de Janeiro: ANPOCS, 1981. Disponível em: <http:// portal.anpocs.org/portal/index.php?option=com_content $\&$ view $=$ article $\&$ id $=493$ $\% 3$ Aanais-do-encontro-gt $\&$ catid $=1066 \% 3$ A5o-encontro $\&$ Itemid=376>. Acesso em: 20 dez. 2015.

CENTRO CULTURAL BANCO DO BRASIL. Tela Negra - o cinema do Blaxploitation: catálogo. Rio de Janeiro, 2011. Catálogo de mostra cinematográfica.

CERQUEIRA, A. P. C. Músicos independentes: um conceito em discussão na cena da música brasileira. IS Working Papers, Porto, série 3, n. 5, p. 1-20, 
dez. 2015. Disponivel em: <http://www.isociologia.pt/App_Files/Documents/ wp5_151217100612.pdf>. Acesso em: 22 dez. 2015.

CLINTON, G. The Godfather of Funk, George Clinton. Site Soul Train. [S.1.], 2015. Entrevista. Disponível em: <http://soultrain.com/2015/12/11/qa-thegodfather-of-funk-george-clinton/>. Acesso em: 8 maio 2016.

COLOMBERO, R. M. M. P. Danças urbanas: uma história a ser narrada. jul. 2011. Disponível em: <http://www.gpef.fe.usp.br/teses/agenda_201109.pdf>. Acesso em: 6 fev. 2016.

COSTA, A. M. Festa na cidade: o circuito bregueiro de Belém do Pará. Belém: EDUEPA, 2009.

CUNHA, M. C. Sociedade e cultura nos anos 1970: esvaziamento cultural e experimentalismo. Revista Dobras, São Paulo, v. 3, n. 5, p. 80-91, 2009.

DE LEVE, I. Black power‘ no Brasil. O Globo, Rio de Janeiro, 1 out. 1977.

DIAS, M. T. Os donos da voz: indústria fonográfica brasileira e mundialização da cultura. São Paulo: Boitempo Editorial, 2000.

DOM FILÓ. Cultura Black na Ativa. Jornal do Brasil, Rio de Janeiro, 26 jul. 2000, Caderno B. p. 1. Entrevista concedida a Adilson Pereira.

DOM FILÓ. Entrevista de Dom Filó sobre os bailes de soul. Blog Pele Negra. [S.1.], 2 nov. 2009. Entrevista concedida a Irohin. Disponível em: <http://pelenegra. blogspot.com.br/2009/11/entrevista-de-dom-filo-sobre-os-bailes.html>. Acesso em: 10 fev 2012.

DOMINGUES, P. Os clubes e bailes blacks de São Paulo no pós-abolição: notas de pesquisa. In: SIMPÓSIO NACIONAL DE HISTÓRIA, 25., Fortaleza, 2009. Anais... Fortaleza: ANPUH, 2009.

DOMINGUES, P. O mito da democracia racial e a mestiçagem no Brasil (18891930). Diálogos Latinoamericanos, Aarhus, n. 10, p. 116-131, 2005.

DOMINGUES, P. Movimento negro brasileiro: alguns apontamentos históricos. Tempo, Rio de Janeiro, v. 12, n. 23, p. 100-122, 2007.

DOURADO, H. A. Dicionário de termos e expressões da música. São Paulo: Ed. 34, 2004. 
DUNN, C. Brutalidade jardim: a tropicália e o surgimento da contracultura brasileira. Tradução de Cristina Yamagami. São Paulo: Editora UNESP, 2009.

EFEGÊ, J. Maxixe: a dança excomungada. 2. ed. Rio de Janeiro: FUNARTE, 2009.

ESCOSTEGUY, A. C. Circuitos de cultura/circuitos de comunicação: um protocolo analítico de integração da produção e da recepção. Revista Comunicação, Mídia e Consumo, São Paulo, v. 4, n. 11, p. 115-135, nov. 2007.

ESSINGER, S. Batidão: uma história do funk. Rio de Janeiro: Record, 2005.

FACCHINI, R. "Não faz mal pensar que não se está só”: estilo, produção cultural e feminismo entre as minas do rock em São Paulo. Cadernos Pagu, Campinas, n. 36, p. 117-153, Jun. 2011. Disponível em: <http://www.scielo.br/scielo. php?script=sci_arttext\&pid=S0104-83332011000100006\&lng $=$ en\&nrm=iso $>$. Accesso em: 17 Jan. 2016.

FEATHERSTONE, M. Cultura de consumo e pós-modernismo. São Paulo: Nobel, 1995.

FÉLIX, J. B. de J. Chic Show e Zimbabwe: a construção da identidade nos bailes black paulistanos. 2000. 202 f. Dissertação (Mestrado em Antropologia Social) - Faculdade de Filosofia, Letras e Ciências Humanas, Universidade de São Paulo, São Paulo, 2000.

FERNANDES, F. A integração do negro na sociedade de classes. São Paulo: Ática, 1978. v. 1.

FERNANDES, F. Música, estilo de vida e produção midiática na cena indie Carioca. Dissertação (Mestrado em Comunicação e Cultura) - Centro de Filosofia e Ciências Humanas, Universidade Federal do Rio de Janeiro, Rio de Janeiro, 2007.

FERNANDES, N. da N. O rapto ideológico da categoria subúrbio: Rio de Janeiro (1858-1945). Rio de Janeiro: Editora Apicuri/Faperj, 2011.

FERREIRA, M. de M. (Coord.). Rio de Janeiro: uma cidade na história. Rio de Janeiro: Editora FGV, 2000.

FERREIRA, M. de M.; GRYNSZPAN, M. A volta do filho pródigo ao lar paterno? a fusão do Rio de Janeiro. In: FERREIRA, M. de M. (Coord.). Rio de Janeiro: uma cidade na história. Rio de Janeiro: Editora FGV, 2000. p. 117-138.

FIGUEIREDO, Â. Fora do jogo: a experiência dos negros na classe média brasileira. Cadernos Pagu, Campinas, n. 23, p. 199-228, jul./dez. 2004. 
FIGUEIREDO, Â. Novas elites de cor: estudo sobre profissionais liberais negros de Salvador. Rio de Janeiro: Annablume, 2002.

FOUCAULT, M. As palavras e as coisas. São Paulo: Martins Fontes, 2002.

FREIRE FILHO, J.; FERNANDES, F. Jovens, espaço urbano e identidade: reflexões sobre o conceito de cena musical. In: CONGRESSO BRASILEIRO DE CIÊNCIAS DA COMUNICAÇÃO, 28. 2005, Rio de Janeiro. Anais... São Paulo: Intercom, 2005.

FREITAS, L. de. Modos de escutar, modos de autoria: as mídias e alguns formatos. Revista Brasileira de Estudos da Canção, Natal, n. 4, p. 41-55, jul./dez. 2013. Disponível em: <http://www.rbec.ect.ufrn.br/data/_uploaded/artigo/N4/ RBEC_N4_A4.pdf>. Acesso em: 1 abr. 2016.

FRESH DRESSED. Direção: Sacha Jenkins. Produção: Mass Appeal. Estados Unidos, 2015. Documentário (90 min). Disponivel em: <https://www.netflix.com/ title/80038962>. Acesso em: 1 abr. 2016.

FRIAS, L. Black Rio: o orgulho (importado) de ser negro no Brasil. Jornal do Brasil, Rio de Janeiro, 17 jul. 1976. Caderno B, p. 1 e 4-6.

FRITH, S. Performing rites: on the value of popular music. Cambridge: Harvard University Press, 1996.

FRY, P. Para inglês ver. Rio de Janeiro: Zahar, 1982.

FRY, P. O que a Cinderela negra tem a dizer sobre a "política racial” no Brasil. Revista USP, São Paulo, n. 28, p. 122-135, 1996.

GARCÍA CANCLINI, N. Consumidores e cidadãos. Rio de Janeiro: Ed. UFRJ, 2008.

GARCÍA CANCLINI, N. Culturas híbridas: estratégias para entrar e sair da modernidade. São Paulo: EDUSP, 1997.

GARCÍA CANCLINI, N. A globalização imaginada. São Paulo: Iluminuras, 2007.

GIACOMINI, S. M. A alma da festa: família, etnicidade e projetos num clube social da Zona Norte do Rio de Janeiro, o Renascença Clube. Belo Horizonte: Editora da UFMG; Rio de Janeiro: IUPERJ, 2006. 
GIACOMINI, S. M. Flor da negritude. Revista de História, [S.1.], [20--].

Disponível em: <http://www.revistadehistoria.com.br/secao/artigos-revista/florda-negritude>. Acesso em: 28 fev. 2013.

GIDDENS, A. Modernidade e identidade. Rio de Janeiro: Zahar, 2002.

GILROY, P. O Atlântico Negro: modernidade e dupla consciência. São Paulo:

Ed. 34; Rio de Janeiro: Universidade Candido Mendes, Centro de Estudos AfroAsiáticos, 2001.

GILROY, P. Entre campos: nações, culturas e o fascínio da raça. São Paulo: Anablume, 2007.

GIRALDO, M. A. S. Funk carioca e champeta cartageneira: corporalidades, transgressões e negociações em músicas e bailes de periferia. 2014. $152 \mathrm{f}$. Dissertação (Mestrado em Antropologia) - Instituto de Filosofia e Ciências Humanas, Universidade Federal do Rio Grande do Sul, Porto Alegre, 2014.

GOMES, N. L. Sem perder a raiz: corpo e cabelo como símbolos da identidade negra. Belo Horizonte: Autêntica, 2006.

GONÇALVES, E. G. Banda Black Rio: o soul no Brasil da década de 1970. 2011. 228 f. Dissertação (Mestrado em Música) - Instituto de Artes, Universidade Estadual de Campinas, São Paulo, 2011.

GONÇALVES, M. das G. Subjetividade e negritude. Cadernos Penesb, Niterói, n. 12, p. 369-383, 2010.

GONÇALVES, V. A história das danças urbanas. Portal Ijuhy.com, [S.l.], 14 abr. 2014. Disponível em: <http://www.ijui.com/especiais/61153-a-historia-dasdancas-urbanas-por-viviane-goncalves.html>. Acesso em: 2 abr. 2016.

GUERRA, P. Alta fidelidade: um roteiro com paragens pelas lojas de discos independentes em Portugal na última década (1998-2010). Sociologia, Porto, v. 21, p. 23-48, 2011.

HALL, S. Da diáspora: identidades e mediações culturais. Belo Horizonte: Editora da UFMG; Brasília, DF: Representação da UNESCO no Brasil, 2003.

HALL, S. A identidade cultural na pós-modernidade. 11. ed. Rio de Janeiro: DP\&A, 1997.

HANCHARD, M. G. Orfeu e poder: movimento negro no Rio e São Paulo. Rio de Janeiro: Ed. UERJ, 2001. 
HASENBALG, C. A. Discriminação e desigualdades raciais no Brasil. Rio de Janeiro: Edições Graal, 1979.

HEBDIGE, D. Subculture: The Meaning of Style. London: Routledge, 1979.

HELLMAN, A. G. A moda no século XXI: para além da distinção social? 2009. 121 f. Dissertação (Mestrado em Sociologia) - Instituto de Filosofia e Ciências Humanas, Universidade Federal do Rio Grande do Sul, Porto Alegre, 2009.

HENNION, A. Pragmáticas do gosto. Desigualdade \& Diversidade, Rio da Janeiro, n. 8, p. 253-27, jan/jul. 2011.

HERMEROTECA DIGITAL BRASILEIRA. Disponível em <http:// hemerotecadigital.bn.br/>. Acesso em: 5 maio 2016.

HERSCHMANN, M. O Funk e o Hip Hop invadem a cena. Rio de Janeiro: UFRJ, 2000.

HERSCHMANN, M. Indústria da música em transição. São Paulo: Estação das Letras e das Cores, 2010.

HOLLANDA, H. B. de. Impressões de viagem: CPC, vanguarda e Desbunde. Rio de Janeiro: Rocco, 1992.

HUMBERTO DJ. Um pouco sobre a equipe Cash Box, o som acima do normal! Blog Radio Antena Hits, 27 jun. 2011. Disponível em: <http://webradioantenahits. blogspot.com.br/2011/06/um-pouco-sobre-equipe-cash-box-o-som_27.html>. Acesso em: 26 abr. 2018.

ICEBERG SLIM: Portrait of a Pimp. Direção: Jorge Hinojosa. Produção: Final Level Entertainment, Estados Unidos, 2012. Documentário (89 min). Disponível em: <https://www.netflix.com/title/70261121>. Acesso em: 12 abr. 2015

JACQUES, T. Comunidade rock e bandas independentes de florianópolis: uma etnografia sobre socialidade e concepções musicais. 2007. 142 f. Dissertação (Mestrado em Antropologia) - Universidade Federal de Santa Catarina, Florianópolis, 2007.

JANOTTI JUNIOR, J.; PIRES, V. Entre os afetos e os mercados culturais: as cenas musicais como formas de mediatização dos consumos musicais. In: JANOTTI JUNIOR, J.; LIMA, T.; PIRES, V. (Org.). Dez anos a mil: mídia e música popular massiva em tempos de internet. Porto Alegre: Simplíssimo, 2011. 
JANOTTI JUNIOR, J.; SOARES, T. Mentiras sinceras me interessam. In: ENCONTRO ANUAL DA COMPÓS, 23., 2014, Belém. Anais... Belém: Compós, 2014.

JANOTTI JÚNIOR, J. Partilhas do comum: cenas musicais e identidades culturais. In: CONGRESSO BRASILEIRO DE CIÊNCIAS DA COMUNICAÇÃO, 35., 2012, Fortaleza. Anais... São Paulo: Intercom, 2012a.

JANOTTI JUNIOR, J. War for territory: cenas, gêneros musicais, experiência e uma canção heavy metal. In: ENCONTRO ANUAL COMPÓS, 21., 2012, Juiz de Fora. Anais... Juiz de Fora: Compós, 2012b.

JOHNSON, R. O que é, afinal, estudos culturais? Belo Horizonte: Autêntica, 1999.

KAHN-HARRIS, K. Roots: The Relationship Between the Global and the Local Within the Global Extreme Metal Scene. Popular Music, Cambridge, v. 19, n. 1, p. 13-30, 2000.

KOSELLECK, R. Futuro-passado: contribuição à semântica dos tempos históricos. Rio de Janeiro: Contraponto, 2006.

LIMA, T. Manguebeat - da cena ao álbum: performances midiáticas de Mundo Livre S/A e Chico Science \& Nação Zumbi. 2007. 179 f. Dissertação (Mestrado em Comunicação) - Faculdade de Comunicação, Universidade Federal da Bahia, Salvador, 2007.

LODY, R. G. da Matta. Cabelos de Axé: identidade e resistência. Rio de Janeiro: Editora SENAC, 2004.

LOPES, A. H. O teatro de revista e a identidade carioca. In: LOPES, A. H. (Org.). Entre a Europa e a África: a invenção do carioca. Rio de Janeiro: Fundação Casa de Rui Barbosa: Topbooks, 2000. p. 13-32.

LOPES, N. Dicionário da hinterlância carioca: antigos "subúrbio" e "zona rural”. Rio de Janeiro: Pallas, 2012.

LOPES, N. Prefácio. In: SOUZA, R. R. de. A confraria da esquina: o que os homens de verdade falam em torno de uma carne queimando: etnografia de um churrasco de esquina no subúrbio carioca. Rio de Janeiro: Bruxedo, 2003.

MACEDO, M. Anotações para uma história dos bailes negros em São Paulo. In: BARBOSA, M.; RIBEIRO, E. (Org.). Bailes soul, samba-rock hip hop e identidade em São Paulo. São Paulo: Quilombhoje, 2007. 
MACIEL, L. C. Geração em transe: memórias do tempo do tropicalismo. Rio de Janeiro: Nova Fronteira. 1996.

MARQUES, J. B. O conceito de temporalidade e sua aplicação na historiografia antiga. Revista de História, São Paulo, n. 158, p. 43-65, 2008.

MARSIGLIA, L. O movimento Black Rio desarmado e perigoso. Super Interessante, São Paulo, abr./ nov. 2015. Disponível em: <http://super.abril.com.br/ cultura/movimento-black-rio-desarmado-perigoso-445240.shtml>. Acesso em: 2 nov. 2014.

MARTÍN-BARBERO, J. Dos meios às mediações: comunicação, cultura e hegemonia. 5. ed. Rio de Janeiro: Editora UFRJ, 2008.

MARTINS, C. H. dos S. A Black music como expressão cultural juvenil em distintos tempos e espaços. Cadernos Penesb, Niterói, n. 11, 2010.

MCCANN, B. Black Pau: uncovering the history of Brazilian soul. Journal of Popular Music Studies, [Oakland], n. 14, p. 33-62, 2002.

MCCRACKEN, G. Cultura e consumo: novas abordagens ao caráter simbólico dos bens e das atividades de consumo. Rio de Janeiro: Mauad, 2003.

MEDEIROS, C. A. Como a Ditadura Espionou o Movimento Negro - E os "Perigosos" Bailes Black. O Menelick $2^{\circ}$ Ato, São Paulo, mar. 2006. Disponível em: $<$ http://omenelick2ato.com/memoria/COMO-A-DITADURA-ESPIONOU-OMNU/>. Acesso em: 20 abr. 2016.

MERCER, K. Black hair/style politics. New Formations, Londres, n. 3, p. 33-54, 1987.

MIDANI, A. Música, ídolos e poder: do vinil ao download. Rio de Janeiro: Nova Fronteira, 2009.

MORAES, S. L. de. Soul mais samba: movimento Black Rio e o Samba nos Anos 1970. 2014. 111 f. Dissertação (Mestrado Em Música) - Centro de Letras e Artes, Universidade Federal do Estado do Rio De Janeiro, Universidade Federal do Rio de Janeiro, Rio de Janeiro, 2014.

MORELLI, R. Indústria fonográfica: um estudo antropológico. Campinas: UNICAMP, 2009.

MORLEY, D.; CHEN, K.-H. (Org.). Stuart Hall: Critical Dialogues in Cultural Studies. Londres: Routledge, 1996. 
MORTARI, E. Identidades negociadas: o rádio e a construção simbólica da Quarta Colônia/RS. 2004. 219 f. Tese (Doutorado em Comunicação) - Escola de Comunicação, Universidade Federal do Rio de Janeiro, Rio de Janeiro, 2004.

MOTTA, M. S. da. Guanabara, o estado-capital. In: FERREIRA, M. de M. (Coord.). Rio de Janeiro: uma cidade na história. Rio de Janeiro: Editora FGV, 2000. p. 79-116.

MOTTA, N. Ano novo, música nova? talvez, nos subúrbios do Rio. O Globo, Rio de Janeiro, 2 jan. 1977. Caderno de Domingo, p. 7.

MOTTA, N. A grande festa do soul. O Globo, Rio de Janeiro, 28 out. 1976.

Cultura, p. 38.

MOTTA, N. Vale tudo: o som e a fúria de Tim Maia. Rio de Janeiro: Objetiva, 2006.

MOTTA-MAUÉS, M. A. Negros em bailes de negros: sociabilidade e ideologia racial no "meio negro" em Campinas (1950/1960). Revista de Antropologia, São Paulo, v. 52, n. 2, p. 705-734, 2009.

MOURA, R. Carta aberta ao Black-Rio. O Pasquim, Rio de Janeiro, p. 2-8, set. 1977.

MOURA, R. A indústria cultura e o espetáculo-negócio no Rio de Janeiro. In:

LOPES, A. H. (Org.). Entre Europa e África: a invenção do carioca. Rio de Janeiro: Topbooks: Fundação Casa de Rui Barbosa, 2000. p. 113-154.

MR. FUNKY SANTOS. Black Rio: o orgulho (importado) de ser negro no Brasil. Jornal do Brasil, Rio de Janeiro, 17 jul. 1976. Caderno B, p. 4. Entrevista concedida a Lena Frias.

MR. FUNKY SANTOS. Cultura Black na Ativa. Jornal do Brasil, Rio de Janeiro, 26 jul. 2000, Caderno B. p. 1. Entrevista concedida a Adilson Pereira.

MUNANGA, K. Rediscutindo a mestiçagem no Brasil: identidade nacional versus identidade negra. Belo Horizonte: Autêntica, 2004.

MUNANGA, K. Negritude: usos e sentidos. São Paulo: Ática, 1988.

NACKED, R. C. Identidades em diáspora: o movimento black no Brasil. Revista Desenredos, Teresina, ano 4, n. 12, p. 1-111, 2012. 
NAPOLITANO, M. Cultura brasileira: utopia e massificação. São Paulo: Contexto, 2001.

NAPOLITANO, M. A música popular brasileira (MPB) dos anos 70:

resistência política e consumo cultural. In: CONGRESSO DE LA RAMA

LATINOAMERICANA DEL IASPM, 4., 2002, Cidade do México. Atas... Cidade do México: IASPM, 2002b. Disponível em: <http://www.educadores.diaadia. pr.gov.br/arquivos/File/fevereiro2012/historia_artigos/2napolitano70_artigo. pdf>. Acesso em: 26 abr. 2018.

NAPOLITANO, M. História \& música: história cultural da música popular. Belo Horizonte: Autêntica, 2002a.

NASCIMENTO, A. do. O genocídio do negro brasileiro. Rio de Janeiro: Paz e Terra, 1978.

NAVES, S. C. Canção popular no Brasil: a canção crítica. Rio de Janeiro: Civilização Brasileira, 2010.

(O) NEGRO da senzala ao soul. Reportagem: Gabriel Priolli Netto, Armando Figueiredo Neto. São Paulo: TV Cultura, 15 jul. 1977. Telejornal (45 min). Disponível em: <https://www.youtube.com/watch?v=5AVPrXwxh1A>. Acesso em: 27 abr. 2018.

NOGUEIRA, O. Preconceito racial de marca e preconceito racial de origem: sugestão de um quadro de referência para a interpretação do material sobre relações raciais no Brasil. Tempo Social, São Paulo, v. 19, n. 1, p. 287-308, 2007. Disponível em: <http://www.scielo.br/scielo.php?script=sci_arttext\&pid=S010320702007000100015\&lng=en\&nrm=iso>. Accesso em: 21 mar. 2016.

NORONHA, L. Malandros: notícias de um submundo distante. Rio de Janeiro: Relume Dumará, 2003.

OLIVEIRA, F. Ditadura perseguiu até bailes black no Rio de Janeiro. O Globo, Rio de Janeiro, 11 jul. 2015. Disponível em: <http://oglobo.globo.com/brasil/ ditadura-perseguiu-ate-bailes-black-no-rio-de-janeiro-16733859>. Acesso em: 20 ago. 2015.

OLIVEIRA, L. L. Cultura urbana no Rio de Janeiro. In: FERREIRA, M. de M. (Coord.). Rio de Janeiro: uma cidade na história. Rio de Janeiro: Editora FGV, 2000. p. 139-150. 
OLIVEIRA, L. X. de. Cenas musicais, experiências identitárias e práticas de consumo: os bailes black no Rio de Janeiro. IS Working Paper, Porto, $3^{a}$ série, n. 9, p. 1-21, 2015a. Disponível em: <http://www.isociologia.pt/App_Files/ Documents/wp9_151218035035.pdf>. Acesso em: 15 abr. 2016.

OLIVEIRA, L. X. de. O swing do samba: uma compreensão do gênero do sambarock a partir da obra de Jorge Ben Jor. 2008. 180 f. Dissertação (Mestrado em Comunicação) - Faculdade de Comunicação, Universidade Federal da Bahia, Salvador, 2008.

OLIVEIRA, L. X. de. Visões sobre o Movimento Black Rio: apontamentos teóricos sobre estilo, consumo cultural e identidade negra. Animus: Revista Interamericana de Comunicação Midiática, Santa Maria, v. 14, n. 27, p. 78-93, 2015b. Disponível em: <http://periodicos.ufsm.br/animus/article/view/17870/ pdf>. Acesso em: 10 jan. 2016.

ORÍ. Direção: Raquel Gerber. Roteiro: Beatriz Nascimento. Fotografia: Hermanno Penna, Jorge Bodanzky, Pedro Farkas, Produção: Ignacio Gerber, Produtora: FCB - Fundação do Cinema Brasileiro. São Paulo: Angra Filmes, 1989. Documentário (94 min). Disponível em: < <https://www.youtube.com/ watch?v=mSikTwQ779w\&t=101s>. Acesso em: 27 abr. 2018.

OSTENDORF, B. Celebration or Pathology? Commodity or Art? The Dilemma of African-American Expressive Culture. Black music Research Journal, Champaign, p. 217-236, v. 20, n. 2, 2000.

ORTIZ, R. A moderna tradição brasileira: cultura brasileira e indústria cultural. São Paulo: Brasiliense, 1999.

ORTIZ, R. Cultura brasileira e identidade nacional. São Paulo: Brasiliense, 2006.

OS CRÍTICOS musicais, segundo Caetano Veloso. Jornal O Globo, Rio de Janeiro, 31 jan. 1979, Segundo Caderno, p. 41.

O SOUL, do Grito Negro à Caderneta de Poupança. Jornal do Brasil, Rio de Janeiro, 8 mar. 1976, Caderno B, p. 5.

PAIVA, C. E. A. Black Pau: a soul music no Brasil nos anos 1970. 2015. 179 f. Tese (Doutorado em Letras) - Faculdade de Ciências e Letras, Universidade Estadual Paulista Araraquara, São Paulo, 2015. 
PALLARES-BURKE, M. L. G. Gilberto Freyre: um vitoriano nos trópicos. São Paulo: Editora UNESP, 2005.

PALOMBINI, C. Soul brasileiro e funk carioca. Opus, Goiânia, v. 15, n. 1, p. 37 61, jun. 2009.

PELEGRINI, S. C. A.; ALVES, A. P. Tornado black' e musical. Revista de História da Biblioteca Nacional, São Paulo, 13 abr. 2011. Disponível em: <http://www. revistadehistoria.com.br/secao/artigos/tornado-black-e-musical>. Acesso em: 5 mar. 2016.

PEREIRA, A. Cultura Black na Ativa. Jornal do Brasil, Rio de Janeiro, 26 jul. 2000, Caderno B. p. 1.

PEREIRA, L. O prazer das morenas: bailes ritmos e identidades no Rio de Janeiro da Primeira República. In: MARZANO, A.; MELLO, V. Vida divertida: histórias do lazer no Rio de Janeiro (1830-1930). Rio de Janeiro: Apicuri, 2010.

PINHO, O. de A. Etnografias do brau: corpo, masculinidade e raça na reafricanização em Salvador. Revista Estudos Feministas, Florianópolis, v. 13, n. 1, p. 127-145, jan. 2005. Disponível em: <https://periodicos.ufsc.br/index.php/ref/ article/view/S0104-026X2005000100009/7816>. Acesso em: 23 abr. 2016.

PINHO, O. de A. A vida em que vivemos: raça, gênero e modernidade em São Gonçalo. Revista Estudos Feministas, Florianópolis, v. 14, n. 1, p. 169198, abr. 2006. Disponível em: <http://www.scielo.br/scielo.php?script=sci arttext\&pid=S0104-026X2006000100010\&lng=en\&nrm=iso>. Accesso em: 25 abr. 2016.

PIRES, T. R. de O. Colorindo memórias e redefinindo olhares: ditadura militar e racismo no Rio de Janeiro. Rio de Janeiro, 2015. Relatório de Pesquisa, Comissão da Verdade do Rio - FAPERJ. Disponível em: <http://www.cev-rio.org.br/site/arq/ Pires-T-Colorindo-memorias-e-redefinindo-olhares-Ditadura-militar-e-racismono-Rio-de-Janeiro.pdf>. Acesso em: 7 jan. 2015.

PIRES, V. de A. N. Cenas musicais: do discurso jornalístico ao estudo acadêmico. In: CONGRESSO DE CIÊNCIAS DA COMUNICAÇÃO NA REGIÃO NORDESTE, 13., 2011. Maceió. Anais... São Paulo: INTERCOM, 2011.

PIVA, E. A. A questão do sujeito em Paul Ricoeur. Síntese, Belo Horizonte, v. 26, n. 85, p. 205-237, 1999. 
PRAXEDES, R. R. Classe média negra no Brasil: negros em ascensão social. Revista Espaço Acadêmico, ano 2, n. 20, jan. 2003.

PRAZER das morenas de Bangu. Jornal do Brasil, Rio de Janeiro, 12 jan. 1927.

PRYSTHON, A. Diferença, pop e transformações cosmopolitas no Recife a partir do Movimento Mangue. Revista Fronteiras: Estudos Midiáticos, São Leopoldo, v. 6, n. 1, p. 33-46, jan./jun. 2004.

(A) QUESTÃO racial: da ditadura à democracia. Programa Caminhos da Reportagem, Reportagem: Débora Brito, Produção: Beatriz Abreu, Rio de Janeiro: TV Brasil, 21 nov. 2014. Programa de TV (53 min). Disponível em: <ttps://www.youtube.com/watch?v=UHCQpM2IK14>. Acesso em: 27 abr. 2018. RACISMO. O Globo, Rio de Janeiro, 26 abr. 1977. Caderno Estado do Rio, p. 10. RANCIÈRE, J. A partilha do sensível: estética e política. São Paulo: Exo: Ed. 34, 2005.

RAMOS, M. J. Re(Des)organizando o movimento: um olhar sobre a música popular brasileira na década de 70. 2007. 101 f. Dissertação (Mestrado em Letras) Departamento de Letras do Centro de Teologia e Ciências Humanas, Pontifícia Universidade Católica do Rio de Janeiro, Rio de Janeiro, 2007.

REIS, A. O "poder negro da beleza": a influência dos movimentos estadunidenses Black is Beautiful e Black Power na obra de Jorge Benjor. In: ENCONTRO INTERNACIONAL DA ANPHLAC, 11., 2014., Niterói. Anais... Niterói: ANPHLAC, 2014.

RIBEIRO, G. Do tédio ao caos, do caos à lama: os primeiros capítulos da cena musical Mangue, Recife - 1980-1991. 2006. 232 f. Dissertação (Mestrado em História) - Instituto de História, Universidade Federal de Uberlândia, Uberlândia, 2006.

RIBEIRO, M. A história da Atlantic Records. Site Whiplash.Net, São Luís. 4 mar. 2013. Disponível em: <http://whiplash.net/materias/biografias/000260.html>. Acesso em: 30 mar. 2016.

RIBEIRO, R. A. da C. Identidade e resistência no urbano: o quarteirão do soul em belo horizonte. 2008. 192 f. Tese (Doutorado em Geografia) - Instituto de Geociências, Universidade Federal de Minas Gerais, Belo Horizonte, 2008. RICOEUR, P. Tempo e narrativa. São Paulo: Martins Fontes, 2010. v. 1. 
RISÉRIO, A. Carnaval Ijexá: notas sobre afoxés e blocos do novo carnaval afrobaiano. Salvador: Corrupio, 1981.

ROCHA, F. Figurações do ritmo: da sala de cinema ao salão de baile. São Paulo: Edusp, 2012.

ROCHA, G. "Navalha não corta seda”: estética e perfromance no vestuário do malandro. Tempo, Niterói, v. 10, n. 20, p. 121-142, 2006. Disponível em: <http:// www.scielo.br/pdf/tem/v10n20/07.pdf>. Acesso em: 18 mar. 2016.

ROCHA, E.; BARROS, C. Entre mundos distintos: notas sobre a comunicação e consumo em um grupo social. In: BACCEGA, M. A. (Org.). Comunicação e culturas do consumo. São Paulo: Atlas, 2008.

RODRIGUES, V. Disco music Made in Brazil: a redemocratização nos embalos da discoteque. 2003. 71 f. Trabalho Conclusão de Curso (Graduação em História) Universidade Federal do Paraná, Curitiba, 2003.

ROSE, T. Black Noise. Londres: University Pess of New England, 1994.

RUBBLE KINGS. Direção: Shan Nicholson. Produção: Saboteur Media. Estados Unidos, 2010. Documentário (71 min). Disponível em: <https://www.netflix.com/ title/80053919>. Acesso em: 27 abr. 2018.

SÁ, S. Will Straw: cenas musicais, sensibilidades, afetos e a cidade. In: JANOTTI JUNIOR, J.; GOMES, I. (Org.). Comunicação e estudos culturais. Salvador: EDUFBA, 2011.

SANTOS, A. Black Rio assusta maestro Júlio Medaglia. Folha de São Paulo, São Paulo, 10 jun. 1977. Caderno Folha Ilustrada, p. 32.

SANTOS, J. T. dos. O negro no espelho: imagens e discursos nos salões de beleza étnicos. Estudos afro-asiáticos, Rio de Janeiro, n. 38, p. 49-65, 2000. Disponível em: <http://www.scielo.br/scielo.php?script=sci_arttext\&pid=S0101-546X2000 000200003\&lng=en\&nrm=iso>. Acesso em: 29 abr. 2016.

SANTOS, M. Por uma outra globalização. Rio de Janeiro: Record, 2001.

SANSONE, L. Negritude sem etnicidade: o local e o global nas relações raciais e na produção cultural negra do Brasil. Salvador: EDUFBA; Rio de Janeiro: Pallas, 2004. 
SAROLDI, L. C. O maxixe como liberação do corpo. In: LOPES, A. H. (Org.). Entre Europa e África: a invenção do carioca. Rio de Janeiro: Topbooks: Fundação Casa de Rui Barbosa, 2000. p. 35-48.

SEVILLA, A. Bailes urbanos. In MEDINA, A. G. et al. Musica y danzas urbanas. México: Secretaria de Cultura, Gobierno del Estado de Jalisco, 2005.

SCOVILLE, E. H. M. L. de. Na barriga da baleia: a Rede Globo de Televisão e a música popular brasileira na primeira metade da década de 1970. 2008. $294 \mathrm{f}$. Tese (Doutorado em História) - Universidade Federal do Paraná, Curitiba, 2008. SCHPREJER, P. Black subversivo. Palma Louca, Rio de Janeiro, 2009. Disponível em: $<$ http://www.palmalouca.com/artes/artes.jsp?id_artes=725>. Acesso em: 10 fev. 2012.

SCHERER-WARREN, I. Movimentos sociais: um ensaio de interpretação sociológica. 2. ed. Florianópolis: Ed. da UFSC, 1987.

SHUKER, R. Vocabulário de música pop. Tradução de Carlos Szlak. São Paulo: Hedra, 1999.

SILVA, C. B. R. Black Soul: aglutinação espontânea e identidade étnica. In: ENCONTRO DA ASSOCIAÇÃO NACIONAL DE PÓS-GRADUAÇÃO E PESQUISA EM CIÊNCIAS SOCIAIS (ANPOCS), 4., 1980, Rio de Janeiro. Anais... Rio de Janeiro: ANPOCS, 1980. Disponível em: <http://portal. anpocs.org/portal/index.php?option=com_docman\&task=doc_details\&gid $=5545 \&$ Itemid $=$ 377 $>$. Acesso em: $19 \mathrm{dez} .2015$.

SILVA, D. F. G. da. O som da diáspora: a influência da black music norte-americana na cena black paulistana. 2013. 320 f. Dissertação (Mestrado em Estudos Culturais) - Escola de Artes, Ciências e Humanidades, Universidade de São Paulo, São Paulo, 2013.

SILVA, J. C. G. da. Paisagens Sonoras no Rap Paulistano: Juventude, Racismo e Segregação Urbana na Cidade de São Paulo. In: CONGRESSO LUSO AFRO BRASILEIRO DE CIÊNCIAS SOCIAIS, 11., 2011, Salvador. Anais... Salvador: CEAO/UFBA, 2011. Disponível em: <http://www.xiconlab.eventos.dype.com.br/ resources/anais/3/1308359027_ARQUIVO_PaisagenssonorasnoRap-CONLABTEXTO.pdf $>$. Acesso em: 2 abr. 2016. 
SILVA, J. C. G. da. Rap na cidade de São Paulo: música, etnicidade experiência urbana. 1998. 285 f. Tese (Doutorado em Ciências Sociais) - Instituto de Filosofia e Ciências Humanas, Universidade Estadual de Campinas, Campinas, 1998.

SOARES, S. A demografia da cor: a composição da população brasileira de 1890 a 2007. In: THEODORO, M. (Org.). As políticas públicas e a desigualdade racial no Brasil: 120 anos após a abolição. Brasília, DF: IPEA, 2008. p. 97-117.

SOARES, T. Abordagens teóricas para estudos sobre cultura pop. Revista Logos, Rio de Janeiro, 2014. Disponível em: <http://www.e-publicacoes.uerj.br/index. php/logos/article/view/14155>. Acesso em: 12 abr. 2016.

SOCIÓLOGO já Alerta Sobre o Black Rio. Jornal do Brasil, Rio de Janeiro, 17 maio 1977. 1. Caderno, p. 14.

SOUZA, R. R. de. A confraria da esquina: o que os homens de verdade falam em torno de uma carne queimando: etnografia de um churrasco de esquina no subúrbio carioca. Rio de Janeiro: Bruxedo, 2003.

SOUZA, T. de. Soul: Sociologia e Mercado. Jornal do Brasil, Rio de Janeiro, 27 ago. 1976, Caderno B, p. 10.

SOVIK, L. Aqui ninguém é branco: hegemonia branca e media no Brasil. In: WARE, V. (Org.). Branquidade; identidade branca e multiculturalismo. Rio de Janeiro: Garamond, 2004. p. 363-386.

SOVIK, L. Aqui ninguém é branco. Rio de Janeiro: Aeroplano, 2009.

SOVIK, L. Cultural Scenes. Loisir et société/Society and Leisure, Québec, v. 27, n. 2, p. 411-422, 2005a.

SOVIK, L. Dance Music. In: FRITH, S.; STRAW, W.; STREET, J. (Ed.). The Cambridge Companion to Pop and Rock. Cambridge: Cambridge University Press, 2001.

SOVIK, L. Por que tenho razão: branquitude, estudos culturais e a vontade de verdade acadêmica. Contemporânea, Salvador, v. 3, n. 2, p 159-180, Jul./dez. $2005 b$.

SOVIK, L. Scenes and Sensibilities. E-Compos, [S.1.], p. 1-16, ago. 2006.

Disponível em: <http://www.compos.org.br/e-compos>. Acesso em: 2 nov. 2010. STRAW, W. Systems of articulation, logics of change: scenes and communities in popular music. Cultural Studies, London, v. 5, n. 3, p. 361-388, oct. 1991. 
STRAW, W. Scenes and Sensibilities. E-Compos, [S.1.], n. 6, p. 1- 16, ago. 2006. Disponível em: <http://www.compos.org.br/seer/index.php/e-compos/article/ viewFile/83/83>. Acesso em: 12 dez. 2015.

TAVARES, J. C. Diáspora africana: a experiência negra de interculturalidade. Cadernos Penesb, Niterói, n. 10, p. 77-86, 2010. Disponível em: <http://www.uff. br/penesb/images/publicacoes/PENESB\%2010.pdf>. Acesso em: 4 mar. 2016.

TAVARES, J. C. Etnografando orfeu afro-brasileiro. Ciber Legenda, Niterói, n. 8, p. 1-10, 2002. Disponível em: <http://www.ciberlegenda.uff.br/index.php/revista/ article/view/344/225>. Acesso em: 28 abr. 2018.

THAYER, A. Black Rio - Brazilian Soul and DJ Culture's Lost Chapter.

Illustration by Alberto Forero. Revista Waxpoetics, New York, n. 16, p. 88-106, Apr./May 2006.

THE BIG BOY SHOW. Direção: Leandro Petersen, Claudio Dager, Rio de Janeiro: Eixo Z Produções, 2003. Documentário (21 min). Disponível em: <http:/| portacurtas.org.br/filme/?name=the_big_boy_sho>. Acesso em: 28 abr. 2018.

THORNTON, S. Club Culture: Music, Media, and Subcultural Capital. New England: Wesleyan University Press, 1996.

TINHORÃO, J. R. Protesto “Black” É Fonte De Renda "White”. Jornal do Brasil, Rio de Janeiro, 14 jun. 1977. Caderno B, p. 2.

TROTTA, F. da C. Cenas musicais e anglofonia: sobre os limites da noção de cena no contexto brasileiro. In: SÁ, S. P. de; JANOTTI JUNIOR, J. (Org.). Cenas musicais. São Paulo: Anadarco, 2013. p. 57-70.

TROTTA, F. da C. Música e mercado: a força das classificações. Contemporânea, Salvador, v. 3, n. 2, p. 181-196, 2005.

TROTTA, F. da C. Samba e Mercado de Música nos Anos 1990. 2006. 264 f. Tese (Doutorado em Comunicação) - Escola de Comunicação, Universidade Federal do Rio de Janeiro, Rio de Janeiro, 2006.

TROTTA, F. da C.; OLIVEIRA, L. X. O subúrbio feliz do pagode carioca. Intercom, São Paulo, v. 38, n. 2, p. 99-118, jul./dez. 2015. Disponível em: <http:// www.portcom.intercom.org.br/revistas/index.php/revistaintercom/article/view/2 283/1907>. Acesso em: 15 jul. 2016. 
TROTTA, F. da C.; SANTOS, K. J. Fideles. Respeitem meus cabelos, brancos: música, política e identidade negra. Revista Famecos, Porto Alegre, v. 19, n. 1, p. 225-248, jan./abr. 2012.

TURISMO vê só comércio no Black Rio. Jornal do Brasil, Rio de Janeiro, 15 maio 1977. $1^{\circ}$ Caderno, p. 20.

VIANNA, H. O baile funk carioca: festas e estilos de vida metropolitanos. 1987.

151 f. Dissertação (Mestrado em Antropologia Social) - Universidade Federal do Rio de Janeiro, Rio de Janeiro, 1987.

VIANNA, H. O mundo funk carioca. Rio de Janeiro, Zahar, 1988.

VIANNA, L. C. R. A idade mídia: uma reflexão sobre o mito da juventude na cultura de massa. Série Antropologia, Brasília, DF, v. 121, p. 1-21, 1992. Disponível em: <http://www.dan.unb.br/images/doc/Serie121empdf.pdf>. Acesso em: 13 mar. 2016.

VICENTE, E. Os dados do Nopem e o cenário da música brasileira de 1965 a 1991. In: CONGRESO DE LA RAMA LATINOAMERICANA DEL IASPM, 7., 2006, Havana. Actas... Havana: IASPM, 2006.

VICENTE, E. Música e disco no brasil: a trajetória da indústria nas décadas de 80 e 90. 2002. 335 f. Tese (Doutorado em Comunicação) - Escola de Comunicações e Artes, Universidade de São Paulo, São Paulo, 2002.

VICENTE, E. Música e disco no Brasil: a trajetória da indústria entre as décadas de 60 e 80. In: ENCONTRO ANUAL DA ANPOCS, 33., 2009, Caxambu. Anais... Caxambu: ANPOCS, 2009.

VICENTE, E. Segmentação e consumo: a produção fonográfica brasileira: $1965-$ 1999. Art Cultura, Uberlândia, v. 10, n. 16, p. 103-121, jan./jun. 2008.

WATTSTAX. Direção: Mel Stuart. Estados Unidos: Stax Records, Wolper Productions, 1973. Documentário. 1 DVD (103 min).

WACQUANT, L. Que é gueto? construindo um conceito sociológico. Revista de Sociologia e Política, Curitiba, n. 23, p. 155-164, 2004.

WILLIAMS, R. Cultura. 2. ed. Rio de Janeiro: Paz e Terra, 1992.

WILLIAMS, R. Marxismo e literatura. Rio de Janeiro: Zahar, 1979. 
WILLIS, P. E. Learning to labour: How Working Class Kids Get Working Class Jobs. Saxon House: London, 1977.

WHITELEY, S.; SKLOWER, J. Countercultures and popular music. Inglaterra: Ashgate Publishing, 2014.

YÚDICE, G. A funkificação do Rio. In: HERSCHMANN, M. (Org.). Abalando os anos 90: funk e hip-hop, globalização, violência e estilo cultural. Rio de Janeiro: Rocco, 1997. p. 22-51.

YÚDICE, G. A conveniência da cultura. Belo Horizonte: Editora da UFMG, 2006.

ZAN, J. R. Jazz, soul e funk na terra do samba: a sonoridade da banda Black Rio. Art Cultura, Uberlândia, v. 7, n. 11, p. 187-200, 2005.

ZUMTHOR, P. Performance, recepção, leitura. Tradução de Jerusa Pires Ferreira. São Paulo: Educ, 2000. 
COLOFĀO

\begin{tabular}{|c|c|}
\hline Formato & $170 \times 240 \mathrm{~mm}$ \\
\hline Tipologia & DTL Haarlemmer / Calibri \\
\hline Papel & $\begin{array}{l}\text { Miolo Alta Alvura } 75 \mathrm{~g} / \mathrm{m}^{2} \\
\text { Capa Cartão Supremo } 300 \mathrm{~g} / \mathrm{m}^{2}\end{array}$ \\
\hline Impressão & Edufba \\
\hline Acabamento & Gráfica 3 \\
\hline Tiragem & 300 exemplares \\
\hline
\end{tabular}

